

\title{
Revista \\ de História \\ da Sociedade \\ e da \\ Cultura
}

Século de Ouro

Siglo de Oro 


\section{$C \mathfrak{S S} \subset$ centrotentrom DA SOCIEDADE \\ E DA CULTURA}

FCT Fundação para a Ciência e a Tecnologia MINISTÉRIO DA EDUCAÇÃo E CIÊNCIA
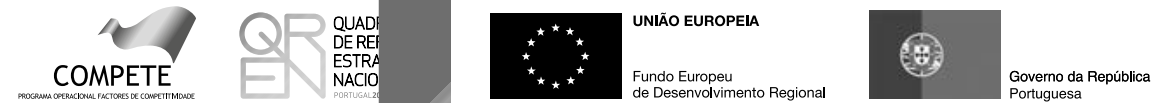

PEST-OE/HIS/UI0311/2014 
Estatuto editorial / Editorial guidelines

A Revista de História da Sociedade e da Cultura, fundada em 2001, é uma revista de periodicidade anual, cujos artigos são sujeitos a avaliação prévia por parte de uma comissão de arbitragem externa. Publica textos de natureza histórica (desde a Idade Média à Época Contemporânea), noticiário de actividades científicas e recensões críticas de livros. Aceita artigos de investigadores integrados e de colaboradores do Centro de História da Sociedade e da Cultura da FCT, bem como de quaisquer outros historiadores externos à instituição, estimulando especialmente a participação de todos aqueles que, de qualquer modo, mantêm colaboração ou desenvolvem actividades em rede com o referido Centro de investigação.

The Journal of History of Society and Culture, founded in 2001, is a peer reviewed scientific publication published once a year. The Journal publishes historical scholarly articles (since the Middle Ages until the present), news of scientific activities and book reviews in the field of History. It accepts articles from affiliated members and collaborators of the Center for the History of Society and Culture - FCT, as well as from any other historians currently outside the Institution, especially encouraging the participation of those who, in any way cooperate or develop network activities with the above-mentioned research Center.

\section{Director / Director}

Irene Vaquinhas - CHSC da U. Coimbra / irenemcv@fl.uc.pt

\section{Conselho Editorial / Editorial Board}

Amadeu Carvalho Homem (CHSC da U. Coimbra); Ana Maria Jorge (CEHR da U. Católica Portuguesa); António Oliveira (CHSC da U. Coimbra); Fernando Catroga (CHSC da U. Coimbra); Fernando de Sousa (CEPESE da U. Porto); Irene Vaquinhas (CHSC da U. Coimbra); João Paulo de Oliveira Costa (CHAM da U. Nova de Lisboa); Mafalda Soares da Cunha (CIDEHUS da Universidade de Évora); Maria Manuela Tavares Ribeiro (CEIS XX da U. Coimbra); Maria Alegria Marques (CHSC da U. Coimbra); Maria Helena Coelho (CHSC da U. Coimbra); Maria José Azevedo Santos (CHSC da U. Coimbra); Zulmira Santos (CIHE da U. do Porto).

\section{Avaliadores externos / External referees}

Adeline Rucquoi (École des Hautes Études en Sciences Sociales - Paris, França); Alice Raviola (U. Turim, Itália); Ana Isabel Buescu (U. Nova de Lisboa, Portugal); Ana Leonor Pereira (U. Coimbra, Portugal); Ângela Barreto Xavier (ICS, Lisboa, Portugal); António Eiras Roel (U. Santiago de Compostela, Espanha); Avelino Freitas Meneses (U. Açores, Portugal); Bernardo Vasconcelos e Sousa (U. Nova de Lisboa, Portugal); Cristina Scheibe Wolff (U. Federal de Santa Catarina, Brasil); Domingo González Lopo (U. Santiago de Compostela, Espanha); Evergton Sales Souza (U. Federal da Bahia, Brasil); Fátima Sequeira Dias (U. Açores, Portugal); Fernanda Rollo (U. Nova de Lisboa, Portugal); Fernando Bouza Alvarez (U. Complutense de Madrid, Espanha); Francisco Contente Domingues (U. Lisboa, Portugal); Francisco Garcia Fitz (U. Cáceres, Espanha); Helena Maria Gomes Catarino (U. Coimbra, Portugal); Hermínia Vasconcelos Vilar (U. Évora, Portugal); Inês Amorim (U. Porto, Portugal); Isabel dos Guimarães Sá (U. Minho, Portugal); Isabel Drummond Braga (U. Lisboa, Portugal); João Paulo Avelãs Nunes (U. Coimbra, Portugal); João Rui Pita (U. Coimbra, Portugal); Jorge Alves (U. Porto, Portugal); José Augusto Pizarro (U. Porto, Portugal); José M. Amado Mendes (U. Coimbra, Portugal); Laura Mello e Souza (U. São Paulo, Brasil); Luís Miguel Duarte (U. Porto, Portugal); Luís dos Reis Torgal (U. Coimbra, Portugal); Luísa Trindade (U. Coimbra, Portugal); Magda Pinheiro (ISCTE-IUL, Portugal); Manuel Ferreira Rodrigues (U. Aveiro, Portugal); Maria Amélia Polónia (U. Porto, Portugal); Maria de Fátima Nunes (U. Évora, Portugal); Maria Helena Santana (U. Coimbra); Maria João Vaz (ISCTE-IUL, Portugal); Maria José Moutinho Santos (U. Porto, Portugal); Maria Marta Lobo (U. Minho, Portugal); Maria Rita Robles Monteiro Garnel (FCSH da UNL, Portugal); Mário Jorge Barroca (U. Porto, Portugal); Nuno Gonçalo Monteiro (ICS, Lisboa, Portugal); Paula Pinto Costa (U. Porto, Portugal); Paulo Almeida Fernandes (CEAUCP-CAM, Portugal); Ramon Villares (U. Santiago de Compostela, Espanha); Raquel Henriques (U. Nova de Lisboa); Rui Bebiano (U. Coimbra, Portugal); Stéphane Boisselier (U. Poitiers, França); Stuart Schwartz (U. Yale, EUA); Susana Serpa Silva (U. Açores, Portugal).

\section{Coordenadores Científicos do volume / Volume editors}

Ana Cristina Araújo / araujo.anacris@sapo.pt | Ignacio Arellano / iarelanno@unav.es

Coordenação Editorial / Editor Coordinator

Sónia Nobre (CHSC da U. Coimbra) / sonianobre@uc.pt

Propriedade / Ownership

Centro de História da Sociedade e da Cultura

Endereços / Address

Faculdade de Letras da Universidade de Coimbra. Largo da Porta Férrea. 3004-530 Coimbra. Portugal.

Normas para a submissão de artigos: chsc.uc.pt • Telefone/Phone: (351) 239859900

Edição: Imprensa da Universidade de Coimbra - IUC

Design e paginação: Sersilito-Empresa Gráfica, Lda.

Depósito legal: 168142/01 • ISSN 1645-2259

Direitos de autor / Copyright $(\mathrm{C}$

Centro de História da Sociedade e da Cultura da Universidade de Coimbra

Reservados todos os direitos de acordo com a legislação em vigor.

Preço de capa / Price

$20 €$

http://dx.doi.org/10.14195/1645-2259_15 


\section{Revista \\ de História \\ da Sociedade \\ e da \\ Cultura}

Século de Ouro

Siglo de Oro 
Lista dos Avaliadores Externos do vol. 15 da Revista de História da Sociedade e da Cultura: Século de Ouro/ Siglo de Oro

Ana Isabel Ribeiro - Universidade de Coimbra

Antonio Azaustre - Universidad de Santiago de Compostela

António Manuel Martins - Universidade de Coimbra

Blanca Oteiza - Universidade de Navarra - GRISO

Emmanuel Marigno - Université Jean Monnet de Saint-Étienne

Fernando Taveira da Fonseca - Universidade de Coimbra

Frederick de Armas - University of Chicago

Isabel dos Guimarães Sá - Universidade do Minho

Isabel Ferreira da Mota - Universidade de Coimbra

Jaume Garau - Universidad de las Islas Baleares

José Antunes - Universidade de Coimbra

José Augusto Cardoso Bernardes - Universidade de Coimbra

José Elías Gutiérrez Meza - Universidade de Heildelberg

Liége Rinaldi - Instituto Anisio Teixeira, Brasil

Lygia Rodrigues Vianna Peres - Universidade Federal Fluminense

Maria Antónia Lopes - Universidade de Coimbra

Maria Teresa Veloso - Universidade de Coimbra

Martina Vinatea Recoba - Universidad del Pacífico, Perú

Oana Sambrian - Academia Romena

Santiago Martínez Hernández - Universidad Complutense de Madrid

Robin Rice - Universidad Popular del Estado de Puebla, México

Victoriano Roncero - State University of Stony Brook, New York

Zulmira Coelho Santos - Universidade do Porto 


\section{Índice}

Editorial

\section{Artigos}

Este bastón es mi padre/ y madre mía esta espada: el poder de las obras y el poder de la sangre en El hijo de las batallas de Jacinto Cordeiro The power of works and the strength of blood in El hijo de las batallas

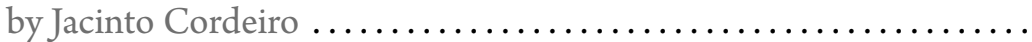

MARIELA INSÚA

La erudita bufonería de La pícara Justina. Algunas notas

The erudite buffoonery of La picara Justina. Some annotations .......

IgNACIO ARELLANo

D. Sebastião e Alcácer Quibir em duas comédias espanholas do Siglo de Oro: La Tragedia del Rey Don Sebastián y del Príncipe de Marruecos, de Lope de Vega, e Comedia Famosa del Rey Don Sebastián, de Luis Vélez de Guevara

Sebastian of Portugal and the battle of Ksar el Kebir in two comedies of the Spanish Golden Age: La Tragedia del Rey Don Sebastián y del Principe de Marruecos, from Lope de Vega, and Comedia Famosa del Rey Don Sebastián, from Luis Vélez de Guevara....................

ANTÓNIO APOLINÁRIo LOURENÇO

El discurso judiciario sobre Don Sebastián y el cometa de 1577

The astrological forecasts about Don Sebastian and the comet of 1577 Jesús M. UsunáRIZ 
Aristóteles en el Banquillo: el prólogo al Libro del Nuevo Cometa de Jerónimo Muñoz

Aristotle in the dock: the prologue to Jeronimo Muñoz' Libro del Nuevo Cometa..........................................

FeLIX K.E. SCHMELZER

Diplomacia e sociabilidade intelectual na viagem a Itália de D. Francisco Manuel de Melo

Diplomacy and intellectual sociability in the italian journey of D. Francisco Manuel de Melo ....................................

Paulo Silva Pereira

En torno a una traducción inglesa del Buscón. "The pleasant story of Paul of Segovia", 1683

Around an English translation of the Buscon: "The pleasant story of Paul of Segovia", 1683 ....................................

J. EnRique Duarte

“QQué amables tus moradas...” (Salmo 84 [Vg 83]), de fray Pedro Malón de Echaide, y el modelo de fray Luis de León para la paráfrasis de los salmos bíblicos

"¡Qué amables tus moradas..." (Psalm 84 [Vg 83]), by fray Pedro Malón de Echaide, and fray Luis de León's model for biblical psalms translation.........................................

CARLos Mata Induráin

Da Hermenêutica da Controvérsia Luterano-Católica ao Diálogo Contemporâneo. O 5. ${ }^{\circ}$ Centenário das 95 Teses de Lutero

From the Hermeneutics of the Luteran-Catholic Controversy to the Contemporary Dialog. The 5th Centenary of the 95 Theses of Luther . 171 Manuel Augusto Rodrigues

Recensões

Notícias. 


\section{Editorial}

A Revista do Centro de História da Sociedade e da Cultura, um património desta unidade de investigação de que todos nos orgulhamos, apresenta-se, neste volume de 2015, em parceria com o Grupo de Investigação O Século de Ouro / El Siglo de Oro (GRISO), da Universidade de Navarra (Espanha), dirigido pelo Prof. Doutor Ignacio Arellano.

Desde a sua fundação, esta Revista tem procurado aprofundar o diálogo com outras áreas das ciências humanas e sociais, o que se tem espelhado na abertura à interdisciplinaridade e à pluralidade de perspectivas teórico-metodológicas, de forma a garantir a amplitude da partilha científica e a internacionalização da produção historiográfica. Reafirma-se também a opção por uma história comparada, demonstrativa de que investigadores de nacionalidades diversas partilham perspectivas e ideias comuns.

O desafio lançado por este número conjunto, fruto de cooperação inter-universitária, sublinha a importância de solidariedades científicas institucionais, tanto formais como informais, consolidadas segundo mecanismos de funcionamento próprios das dinâmicas de redes, assumindo-as como um meio privilegiado de alargamento do espectro de leitores, de integração no panorama da produção historiográfica actual e de contributo para os debates do tempo presente.

A coordenação deste número da Revista, o primeiro organizado segundo um modelo bi-tutelado, à escala internacional, esteve a cargo dos Doutores Ana Cristina Araújo e Ignacio Arellano, respectivamente por parte do CHSC e do GRISO (UN), especialistas de História Moderna, a quem muito se agradece o empenhamento pessoal e institucional. Sem o seu conhecimento, dedicação e cuidado, teria sido bem mais difícil organizar a publicação deste volume.

A gratidão é extensiva a todos os autores (de artigos, de recensões críticas e de notas de leitura) que disponibilizaram os resultados das suas investi- 
gações, bem como aos avaliadores, cujas leituras críticas e atentas possibilitaram o enriquecimento dos textos finais. Uma palavra ainda de reconhecimento para a Imprensa da Universidade de Coimbra, a nossa editora a partir deste número, com quem esperamos manter um relacionamento duradouro e proveitoso.

Irene Vaquinhas

Coordenadora Científica do CHSC irenemcv@fl.uc.pt 
Artigos 



\title{
Este bastón es mi padre/ y madre mía esta espada: el poder de las obras y el poder de la sangre en El hijo de las batallas de Jacinto Cordeiro*
}

\section{The power of works and the strength of blood in El hijo de las batallas by Jacinto Cordeiro}

\author{
MARIELA InsúA \\ Universidad de Navarra - GRISO \\ minsua@unav.es
}

Texto recebido em / Text submitted on: 15.09.2015

Texto aprovado em / Text approved on: 15.10.2015

Resumen: Este trabajo aporta un análisis de la comedia El hijo de las batallas (1630) de Jacinto Cordeiro, dramaturgo perteneciente al grupo de autores portugueses que escriben en castellano en la época de la Monarquía Dual (1580-1640). Se estudia la obra teniendo en cuenta su posible fuente de inspiración -El hijo Venturoso de Lope de Vega-, la relación entre el poder de las propias obras frente a la fuerza de la sangre, y su adscripción genérica híbrida, pues incluye elementos del género palatino y del drama de privanza.

Palabras clave: Jacinto Cordeiro, El hijo de las batallas, teatro hispano-portugués, comedia palatina, drama de privanza.

Abstract: This article offers an analysis of El hijo de las batallas (1630), comedy by Jacinto Cordeiro, dramatist that belongs to the group of lusitan authors that write in Spanish during the Dual Monarchy period (1580-1640). The work studies different aspects in the play: the possible source of inspiration - El hijo Venturoso by Lope de Vega -, the connection between the power of the own works and the strength of blood, and its hybrid genre that includes elements of the palatine genre and the privanza drama.

Keywords: Jacinto Cordeiro, El hijo de las batallas, Hispano-Portuguese Theatre, palatine genre, privanza drama.

Resulta indiscutible que Jacinto Cordeiro (1606?-1646) ${ }^{1}$ ocupa un lugar destacado dentro del corpus teatral conformado por los dramaturgos portu-

* Este artículo se inserta en el marco del proyecto de investigación FFI2014-52007-P, «Autoridad y poder en el teatro del Siglo de Oro. Estrategias, géneros, imágenes en la primera globalización», financiado por el Ministerio de Economía y Competitividad del Gobierno de España.

1 Más detalles de la biografía de Jacinto Cordeiro se encontrarán en Cruz Ortiz 2009 y 2013 y Gonzalez 1987 y 2002. 
gueses que escriben en español y cuyas obras se representan en Lisboa y en otras ciudades portuguesas y españolas durante el período conocido como la Monarquía Dual (1580-1640). Ya indicaba Ares Montes, uno de los pioneros en el rescate de la figura del autor lisboeta, que este seguidor de la escuela de Lope de Vega podía ser considerado el "mejor dramático portugués del siglo XVII” (Ares Montes 1992: 52). Su producción teatral conformada por dieciséis piezas ${ }^{2}$ lo convierte en uno de los autores más prolíficos en el marco del fenómeno de la comedia hispano-portuguesa, junto con Juan de Matos Fragoso.

La crítica ha señalado que el poder y sus concomitancias constituyen una de las directrices temáticas fundamentales de la dramaturgia de Cordeiro (Gonzalez 2002: 185, Insúa 2012: 188, Insúa 2015), la cual es planteada desde distintas posibilidades genéricas y de acuerdo a las convenciones compartidas por la Comedia Nueva. Encontramos de este modo piezas que tratan la cuestión de la autoridad en el drama de privanza como en la bilogía Próspera y Adversa fortuna de Duarte Pacheco ${ }^{3}$; mientras que en otras el tema del ascenso y caída en desgracia del favorito es asumido desde el género de la comedia palatina: es el caso de Lo que es privar ${ }^{4}$, donde se combinan los recursos propios de la intriga eminentemente amorosa con reflexiones del valimiento modélico; o de La privanza merecida, en la cual se retoma este mismo asunto con mayor desarrollo en lo que a la constitución del privado ejemplar se refiere, en plena sintonía con los tratados políticos de la época acerca del ars gubernandi $i^{5}$. También el género palatino ofrece un molde apropiado al portugués para reflexionar sobre las virtudes en el ejercicio del poder y el enfrentamiento entre el privar y el amar, como en Con partes no hay ventura y Non plus ultra. Amar por fuerza de estrella un portugués en Hungría. Siguiendo con esta línea de enredos dramáticos que imbrican amor y conflictos en el ascenso social, se puede mencionar $E l$ secretario confuso ${ }^{6}$, obra perteneciente al subtipo palatino de secretario centrada en el motivo de la dama noble que se enamora del suyo. En otras piezas, en cambio, Cordeiro se enfrenta a cuestiones de tratamiento serio como el tiranicidio en El mal incli-

2 De acuerdo al conteo realizado por Cruz Ortiz (2010:334), que parte del Catálogo razonado (1890) de Domingo García Peres.

3 Estudiada en Insúa 2012.

4 Una aproximación a esta obra en Insúa 2011.

5 Depetris señala la posible influencia en esta pieza de Cómo ha de ser el privado de Quevedo y especialmente del Discurso de las privanzas también de atribución quevediana (Depetris en estudio preliminar a Cordeiro, La privanza merecida: 41-46).

6 Un análisis de esta pieza en Insúa 2015. 
nado ${ }^{7}$ o la confrontación entre la fuerza de la sangre y la autodeterminación en El hijo de las batallas. A esta última dedicaré mi análisis en las próximas páginas.

El hijo de las batallas se recoge en el volumen Seis comedias famosas del alférez Jacinto Cordero (Lisboa, por Lorenço Craesbeeck, 1630), junto con Amar por fuerza de estrella, El juramento ante Dios, El mayor trance de honor y la Primera y la Segunda parte de Duarte Pacheco. Hasta el momento no se ha encontrado un ejemplar completo de la edición de 1630 que incluya El hijo de las batallas. Tal como indica Gonzalez, en el único trabajo dedicado a esta comedia (2009: 241), el texto nos llega a partir de varias sueltas de Madrid, Coimbra, Valencia, Boston Public Library, British Library, todas ellas sin fechar. Contamos también con una suelta de la Bayerische Staats Bibliothek, sin lugar ni año, y otra suelta impresa con licencia en Sevilla, Imprenta Real, Casa del Correo Viejo, sin año y paginada, que se encuentra en la Universidad de Sevilla -signatura A 250/095(04) - y que utilizaré como texto de referencia para las citas de este estudio.

Constan tres representaciones de El hijo de las batallas: la primera en el patio de las Arcas de Lisboa por Manuel Simón en 1625; la segunda, también de ese año en torno al 4 de octubre, a cargo del mismo autor en Coimbra a petición de la Universidad y con motivo de las fiestas por la canonización de la reina Isabel de Portugal. Se indica la posibilidad de que fuera representada en una plaza pública en un tablado costeado por el municipio. La última es una representación particular en Madrid, en palacio ante su Majestad, a cargo de Pedro de Valdés en 1628, pues consta un pago al autor por esta puesta en escena en marzo de ese $a \tilde{n} 0^{8}$. Curiosa es también la presencia de un par de obras de Cordeiro en latitudes lejanas, como en Charcas. Así, según recoge Gisbert, dentro del teatro charqueño que no puede ser considerado stricto sensu como parte del corpus, figura la Comedia famosa El juramento ante Dios $y$ Lealtad contra el amor, que según esta autora es presumible que fuera representada durante el virreinato ${ }^{9}$; y en relación con este repertorio charqueño se ha mencionado también la inclusión del título de El hijo de las batallas (Arellano 2005: 195), sin indicaciones de su posible representación.

Existe asimismo una versión en italiano de esta pieza, Il figlio della battaglia (Napoli, Bartolomeo Nicola Moreschi, 1669), de Giovanni Battista

Abordada en Gonzalez 2012.

8 Datos consignados en Ferrer et al., Base de datos de comedias mencionadas en la documentación teatral (1540-1700). CATCOM. Ver también Gonzalez, 2009: 243, n. 1.

9 Gisbert, Esquema de la literatura virreinal en Bolivia, La Paz, Universidad Mayor de San Andrés, 1968 : 65. Referencia tomada de Eichmann 2005: 339, n. 82. 
$\mathrm{Pasca}^{10}$. En esta obra se reitera el argumento de la comedia de Cordeiro, con prácticamente el mismo reparto de personajes, aunque con cambios menores que consisten en la italianización de varios nombres y ciertas modificaciones en la caracterización de algunos de ellos (el gracioso, por ejemplo, aparece como napolitano); el espacio dramático es el mismo, con la única variación de que el reino con el que se enfrenta Inglaterra es Escocia y no Bohemia como en la pieza de Cordeiro.

El hijo de las batallas responde a las convenciones propias del modelo palatino: nos encontramos así con personajes que pertenecen a la alta nobleza -los reyes de Inglaterra y Bohemia, nobles y servicio de la corte- y otros de origen villano en relación con los primeros; con lo cual entran en conexión dos espacios dramáticos, el propiamente palaciego y la aldea. La atmósfera se muestra pretérita y exótica, con una ambientación no identificable como cercana para los espectadores contemporáneos: la acción transcurre en la aldea de Gravesendí, el palacio de Londres, un campo de batalla $y$ un bosque, con referencias a sucesos ocurridos previamente en el reino de Bohemia. Como en otras obras de esta modalidad, la acción se basa en la desestabilización de un orden, que trae aparejada la ocultación de identidades, para finalizar con el restablecimiento de ese orden y la recuperación de la identidad (Oleza 1986: 266). En esta pieza el resorte dramático de amor y celos se halla presente en historias amorosas cruzadas de los personajes; sin embargo, la acción no se erige únicamente sobre ese eje amoroso -como en la comedia palatina cómica prototípica- sino que en este caso se aporta además una línea de tratamiento serio relacionada con el descubrimiento del origen, el poder, la privanza y la relación entre el mérito y el linaje. Retomaré este asunto del género más adelante.

\section{Una posible fuente de inspiración: El hijo Venturoso de Lope de Vega}

El germen argumental de El hijo de las batallas lo constituye la búsqueda de la propia identidad y valía por parte del protagonista, Delfín, quien, dado a luz en una aldea por una dama noble deshonrada, descubre al llegar a la juventud que su vocación no está en las labores rústicas sino en el campo de batalla. En este espacio de la guerra el héroe pasa a ser valorado por los otros y se autoafirma como hijo de sus propias obras, en este caso vinculadas al ejercicio de las armas. Podría plantearse que este punto generador

10 La filiación de estas dos obras es mencionada por Cruz Ortiz 2013: 7. 
de la intriga en la pieza de Cordeiro tiene como antecedente una comedia novelesca de Lope de Vega, El hijo Venturoso, construida sobre un esquema similar ${ }^{11}$. A su vez esta obra -que según Morley y Bruerton (1968: 42) fue compuesta por el Fénix en el período 1588-1595-, se halla posiblemente inspirada, según ha indicado la crítica, en una novella de Giraldi Cinthio ${ }^{12}$ incluida en los Hecatommithi (1565), colección que gozó de cierto éxito en Italia y el extranjero (Aldomá García 1993: 15). Es probable que se conociera en España directamente de la versión italiana, pero contó además con una traducción de Luis Gaytán de Vozmediano bajo el título Primera parte de las cien novelas de M. Juan Baptista Giraldo Cinthio (Toledo, por Pedro Rodríguez, 1590), donde se incluye la novella mencionada ${ }^{13}$. En ella el protagonista, llamado Avventuroso, es abandonado junto a la ribera de un río; allí lo encuentran unos pastores que lo crían como propio y, veinte años después y tras haber alcanzado la gloria con las armas y convertirse en capitán, el héroe encuentra a su madre y le restituye la honra al conseguir que su padre se case con ella. Esto último, como veremos, no sucederá en la comedia de Cordeiro, pero sí se aprecian elementos de conexión entre ambas obras: el nacimiento clandestino, la crianza en un medio rústico, la posterior incomodidad de los protagonistas en ese ámbito villano, el cambio de destino por el desempeño del oficio de las armas en el cual destacan y ocupan un rango superior al que en principio les correspondería dado su aparente origen (los Venturosos de Giraldi Cinthio y de Lope se convierten en capitanes y el Delfín de Cordeiro en general). En los tres casos se producirá la anagnórisis con sus progenitores a los veinte años del abandono ${ }^{14}$.

Como podemos apreciar, El hijo Venturoso y El hijo de las batallas coinciden en la trayectoria heroica de un personaje que busca su identidad. Se ha señalado, en efecto, que esta comedia temprana de Lope pertenece a un subgrupo caracterizado por la presencia del motivo de la pérdida identitaria, el cual se daría a partir de tres movimientos que se aprecian en las dos piezas que estudio: el proceso de llegar a ser, el desenlace con la revelación y la consiguiente eliminación de la duda (Glenn 1973: 616). En el recorrido hacia

11 Según se señala en ARTELOPE-Base de datos y argumentos del teatro de Lope de Vega, desde el punto de vista genérico esta pieza resulta sumamente híbrida, «pues a pesar del dilatado y novelesco transcurso del tiempo y de la intriga, sitúa la acción, que es muy fantasiosa, en una época histórica concreta, y entremezcla ambientes nobiliarios, burgueses, aldeanos y bélicos».

12 Ver Templin 1934.

13 Correspondiente a la Novella Prima, Prima Deca, de los Hecatommithi.

14 En otra comedia posterior, La esclava de su hijo, de atribución dudosa a Lope de Vega según Morley y Bruerton (1968: 460-461), y posible refundición de El hijo Venturoso, se reitera este mismo esquema argumental. Ver Templin 1934. 
el propio descubrimiento en este grupo de Lope y también en la pieza de Cordeiro se observa además una oscilación del personaje entre el deseo de reencontrar el propio ser originario y el de convertirse en nuevo ser autodeterminado (Glenn 1973: 610). En los dos casos que analizo los protagonistas parten de la aldea para llegar a un ambiente cortesano portando sus propios valores y en ese espacio al que arriban provocan cambios, a través de la carrera militar pero sobre todo por su conducta ejemplar.

\section{El hijo de las batallas: entre el poder de las obras y el poder de la sangre}

En el comienzo de la primera jornada de la comedia de Cordeiro se activa el principio dinámico que Gonzalez considera el motor de esta pieza: la no conformidad entre la esencia y la existencia del protagonista (2009: 244). Así, vemos a Delfín discutiendo con su hermano Doricleo por no querer el primero participar en las labores campesinas al sentirse llamado a otras lides mayores. La caracterización que de Delfín hace su hermano adquiere rasgos quijotescos, al definir su obsesión por la batalla como una "locura inmortal” (p. 1): nos lo muestra esgrimiendo un palo a modo de espada en lugar de preocuparse del ganado, imaginando en su fantasía que es general de un escuadrón real. Esta relación de Delfín con don Quijote será planteada explícitamente más adelante cuando el gracioso Pinalvo se considere su Sancho Panza en el momento en el que se despiden de la aldea para partir en busca de aventuras ${ }^{15}$. De esta discusión inicial entre los hermanos surge el agravio que genera la confesión del origen de Delfín y su posterior abandono del espacio en el que fue criado. Doricleo lo insulta con un "mejor que tú soy nacido", Delfín intenta atacarlo y le llama mentiroso. Ante esta situación, Toralvo, el

15 Estos versos se encuentran en el testimonio de la Bayerische Staats Bibliothek (s. 1., s. a. y sin foliación), no figuran en el texto de la Universidad de Sevilla por el que cito:

Adiós, aldea fruncida,

ollas, mondongos, tabernas,

adiós, Pinalvo se parte

$y$ en vos el alma se queda.

A la guerra voy, amigos,

mas ¿a qué voy a la guerra,

si aunque me maten a palos

cólera jamás me llega?

Más probemos aventuras

por los bosques, por las selvas.

Adiós, aldea, por Panza

hoy don Quijote me lleva. 
anciano padre, se ve obligado a confesar su origen a Delfín y lo conmina a que parta a la guerra para evitar la venganza del hermano mayor. De este modo, desde prácticamente el inicio de la obra se siembra en el protagonista la duda acerca de quiénes fueron sus padres. En esta primera instancia su padre adoptivo le confiesa que hace veinte años una dama de belleza sin par lo dio a luz en su humilde morada y le puso por nombre Delfín, y le trasmite las palabras que escuchó de boca de su madre antes de partir de la aldea cubierta de pieles para no volver nunca, dejándole como única prenda a su vástago el retrato de un hombre y unas letras enigmáticas, “T P B”. En aquellas palabras se adelantaba el destino desgraciado de ella y también la doble condición de su hijo, noble por origen pero villano por culpa de los actos de su progenitora:

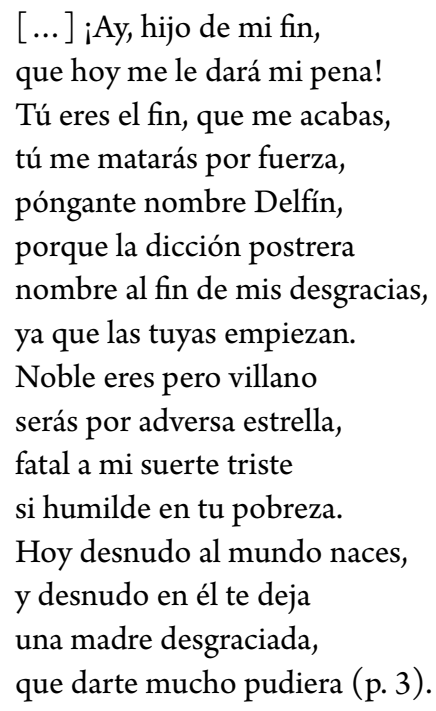

Tras escuchar esta confesión Delfín debe partir a la guerra, pues el agravio a su hermano hace imposible que permanezca en la aldea sin correr peligro. En ese nuevo espacio bélico tal vez, como dice Toralvo, el por origen desgraciado podría alcanzar "próspero el fin" (p. 4). A partir de este momento comienza a evidenciarse el conflicto interior del héroe, que ha de velar por glorias propias para aplacar la duda existencial que le produce ese origen enigmático. Por ello en el monólogo que profiere Delfín tras la despedida señala, haciendo referencia a la imagen emblemática del pavo real como ilustración de la vana soberbia, que prefiere "ser villano honrado antes, / que no noble en contingencia" (p. 4). Ante esta incertidumbre vital verá en la consecución de las propias obras un modo de hacerse a sí mismo, de desvincularse del conflicto originario. Se 
plantea así la posibilidad del nuevo nacimiento del héroe al amparo de su ventura, sin progenitores, siendo hijo de sí mismo:

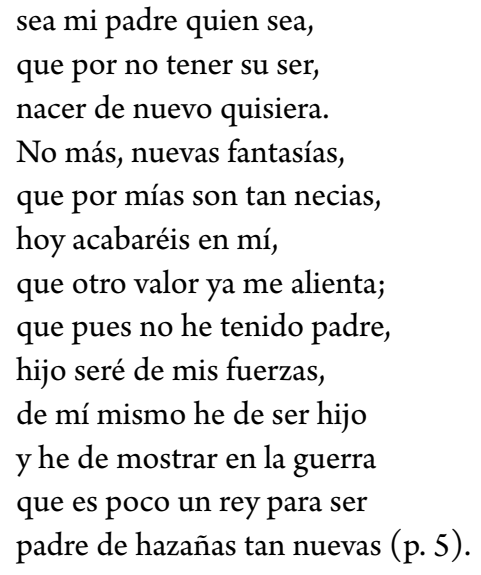

Encontramos en estas palabras un claro eco de aquellas de don Quijote cuando le decía a Andresillo que poco importaba el origen noble o no de Juan Haldudo pues "cada uno es hijo de sus obras" (Quijote, I, 3: 65), o de aquellas otras proferidas por el hidalgo para contrarrestar la idea de la fortuna que Sancho describía en forma de mujer borracha y antojadiza: "cada uno es artífice de su propia ventura” (Quijote, II, 66: 1168), haciendo referencia al célebre aforismo de Claudio Apio. La idea se enmarca en la concepción presente en algunos pensadores de la época consistente en que el hombre crea su linaje de acuerdo a su comportamiento. Recuérdense a este respecto las palabras de Huarte de San Juan en su Examen de ingenios:

Cuando el hombre hace algún hecho heroico o alguna extraña virtud o hazaña, entonces nace de nuevo, y cobra otros mejores padres, y pierde el ser que antes tenía: ayer se llamaba hijo de Pedro y nieto de Sancho; ahora se llama hijo de sus obras (de donde tuvo origen el refrán castellano que dice cada uno es hijo de sus obras) (Huarte de San Juan 1989: 553-554).

Ante este postulado no tiene cabida la fatalidad sino la autodeterminación de labrarse el propio destino. Esto es lo que se proponía don Quijote al salir al camino, es también lo que pretende Delfín en su despertar heroico y asimismo el protagonista de El hijo Venturoso. En efecto, el personaje de Lope encuentra en las hazañas heroicas -se pone al servicio del ejército francés en 
contra de su Milán natal ${ }^{16}$ - una posibilidad de cambio, de dejar atrás su condición de "hijo de un río" para pasar a estar "concebido" nuevamente por la guerra. De este modo, en la tercera jornada de la pieza lopesca encontramos a un Venturoso convertido en famoso capitán. Algunos de sus compañeros se niegan a aceptar esta condición debido a su origen supuestamente villano. Uno de ellos, en cambio, les responde que en la guerra es posible nacer de nuevo mediante la virtud en el ejercicio de las armas:

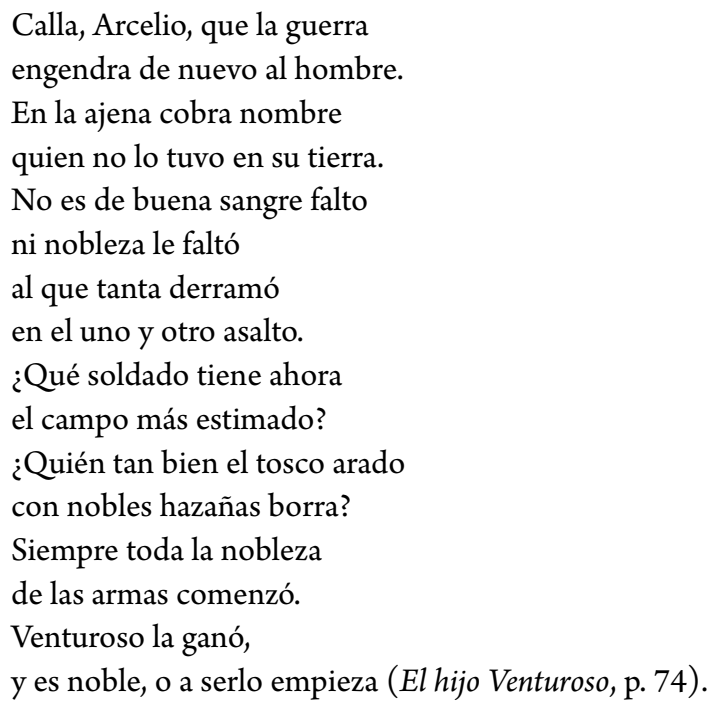

Checa plantea que el hilo conductor de El hijo Venturoso es justamente la afirmación de una autonomía ontológica del héroe que se logra gracias al cultivo de valores de índole marcial. De este modo,

el tópico, remozado por el pensamiento humanístico, de la consecución de nobleza mediante actos encomiables cobra singular vigencia en la vida militar y particularmente en la guerra, toda vez que una de sus virtudes potenciales consiste en que "engendra de nuevo al hombre" (Checa 2011: 7).

Este planteamiento se afirma además en una corriente de tratadística militar vigente en la época que respaldaba la meritocracia frente al otorgamiento de cargos únicamente por nobleza heredada o favoritismo del poderoso (Espino López 2001: 80-90). Esto contribuye, por otro lado, a producir una

16 En la novella de Giraldi Cinthio, Avventuroso también entra al servicio del francés y, desde el bando enemigo, consigue como capitán rescatar a su madre de los propios hombres que comanda. Este mismo patrón argumental es retomado por Lope en su comedia. 
matización en la concepción generalizada de la soldadesca solamente como autora de males y pillajes para volcarse hacia una valoración del soldado cuya nobleza se asienta en las acciones encomiables (García Hernán 2006: 137). Así, por ejemplo, se refiere Bernardino Barroso en Teórica, práctica y ejemplos de guerra (Milán, 1622) justamente con respecto al rango de capitán, al plantear que debía ser ante todo "el mejor soldado de su compañía" y que no se podía despreciar para ocuparlo al "pobre aunque no sea de ilustres progenitores con tal que sea famoso, y muy estimado por su propia virtud $y$ esfuerzo, porque la virtud es fundamento, fin y blanco de la nobleza" ${ }^{17}$. Como podemos apreciar, tanto El hijo Venturoso como El hijo de las batallas, desde géneros no pertenecientes a lo que se ha dado en llamar "dramas historiales de hechos famosos" (Checa 2011: 6), es decir no abocados en principio al tratamiento específico de acciones vinculadas al mundo heroico de la guerra, muestran en su trasfondo una reflexión coincidente con los planteamientos señalados acerca del mérito en la carrera de las armas. En la comedia de Cordeiro, partiendo desde su propio título, se resalta la actividad bélica como medio no solamente para conseguir fama sino también el fundamento del propio ser.

En primer término, la aventura marcial en El hijo de las batallas trae al protagonista un reconocimiento derivado de su virtus militar. Luego veremos que ese premio al mérito se verá además acompañado por la vinculación con el linaje noble del personaje, en un comienzo desconocido. Así, tras su partida de la aldea de Gravesendí, nos encontramos a Delfín llamado a la lucha por los sones de la guerra que está teniendo lugar entre los reinos de Bohemia e Inglaterra. Esta contienda se plantea de acuerdo a las convenciones del género palatino con el exotismo y la indeterminación espacio-temporal que le son propios: Enrico, el rey de Inglaterra, ha de enfrentarse en batalla con el de Bohemia para vengar la muerte de su heredero, quien había sido derrotado en una justa por dicho rey. Delfín irrumpe en medio de la refriega portando como única arma el tronco de un árbol, que contrasta con las galas de los soldados allí presentes, "aquellos de tela y bandas, / todo ligas, todo plumas", los cuales, como indica el gracioso Pinalvo en clave jocosa (p. 8), solo miran cómo se matan sus compañeros. Frente a esto Delfín representa la opción del guerrero valiente a secas, que se lanza a la lucha sin pensar en el peligro y defiende al rey de Inglaterra abandonado por los suyos. Por ello podrá decirle al de Bohemia antes de vencerlo:

17 Citado por Espino López 2001: 83. 
Negome naturaleza

la ostentación de sus galas,

pero diome este valor

para vencer tu arrogancia (p.9).

Y tras ello Delfín hará gala de su virtud al mostrarse compasivo con su enemigo: lo deja en tierra sin quedarse con la espada del vencido para que este no pierda su honor y lo ampara ante el rey de Inglaterra para que no lo mate. El encuentro entre Delfín y el rey de Inglaterra avanza un motivo recurrente en estas comedias relacionadas con la búsqueda de la identidad, el cri du sang (Glenn 1973: 615) consistente en una extraña atracción mutua de los personajes al conocerse, los cuales, como se descubrirá más adelante, son padre e hijo: "y la sangre se derrama / por las venas de alegría” (p.9), dirá Enrico al ver a su salvador. El guerrero es recompensado inmediatamente con el nombramiento de general. En este caso se premia el mérito, en efecto, pero también pesa en la decisión del monarca la intuición de que es alguien de su estirpe: "en el alma / dicen todas mis potencias / que mi sangre le acompaña" (p. 9). A partir de este momento habrá varias instancias en las cuales sangre y mérito se vean reunidos. Sin embargo, desde el punto de vista de Delfín, que no imagina su origen noble, sigue presente la idea de la autodeterminación y de la consecución de logros por el propio valor; para él en la batalla se ha producido un nuevo alumbramiento, comienza a existir a partir de ella. Por ello se presenta ante el rey diciendo:

haga cuenta que nací

hoy mismo en esta campaña.

Este bastón es mi padre

y madre mía esta espada:

vos, señor, sois el padrino,

mucha nobleza me ampara.

Mi proprio nombre es Delfín,

$\mathrm{y}$ si vos queréis que salga

mi nombre de mi valor,

pues tanto aquí se señala,

decid a todos que soy

el hijo de las batallas (p. 10).

Recuerda este pasaje lo expresado por Huarte de San Juan cuando ejemplificaba el nuevo nacimiento que puede producirse en los hombres gracias a 
sus obras heroicas. Entonces recordaba las palabras que un capitán valeroso carente de buen linaje dirigió en cierta ocasión a otro de nobleza campanuda:

Señor, dijo el capitán, bien sé que vuestra señoría es muy buen caballero y que sus padres lo fueron también, pero yo y mi brazo derecho, a quien ahora reconozco por padre, somos mejores que vos y todo vuestro linaje (Huarte de San Juan 1989: 558).

La primera jornada de El hijo de las batallas culmina con Delfín convertido en privado del rey. A partir de este momento se apreciará en la obra la introducción de varios motivos característicos del género de privanza, los cuales combinados con los propios del palatino serio y algún añadido trágico harán de esta pieza un singular caso de hibridismo genérico.

\section{Aspectos genéricos en El hijo de las batallas}

Oleza y Antonucci plantean que el género palatino va transformándose con el desarrollo de la Comedia Nueva. Se mantienen ciertos rasgos típicos como el exotismo, la indeterminación temporal y la alta alcurnia de los personajes, pero se produce un cambio fundamental justamente en el modo de abordar el tema de la identidad perdida o disfrazada del protagonista, núcleo básico en la primera comedia palatina, el cual pasa a ser abordado de dos maneras funcionales distintas: una meramente cómica, centrada en el disfraz, y otra seria (dramática o trágica) vinculada con el desposeimiento de la propia identidad. Ejemplifican esta renovación de la modalidad palatina en la producción del último Lope a partir de 1627 e indican que también se observaría esta modificación en la matriz de rasgos genéricos en Calderón y en Rojas (Oleza y Antonucci 2013: 729-730). Considero que este postulado sería también aplicable a El hijo de las batallas de Cordeiro, la cual pertenecería al último caso aducido por los críticos, el palatino de trasfondo serio o grave, pues, en efecto, y como he adelantado, la pérdida de la propia identidad originaria es el eje conductor del drama.

El enredo amoroso centrado en la desigualdad social está presente en la obra pero de un modo secundario: Delfín, privado del rey de Inglaterra, y Linda, hija ilegítima de este y futura heredera del trono, se sentirán atraídos mutuamente (antes de saber que son hermanos de padre y madre), pero todo queda en un cortejo que no adquiere más desarrollo que el atisbo de un riesgo de incesto que no se lleva a cabo (Gonzalez 2009: 246). Por otro 
lado, existe entre estos dos personajes un paralelismo en la presentación del conflicto con su origen: Linda no es aceptada por su madrastra, la reina, porque viene de madre infame y le dice que por ello no podrá suceder a su esposo en el trono. Del mismo modo que Delfín hace con Toralvo, Linda, ante su duda existencial, pedirá a quien la ha criado, el duque Florando, que le revele quién es su madre. Algunos elementos se reiteran en ambos relatos y se completan con otros diferentes en la narración del duque: una dama de origen noble, de nombre Fidelina, es galanteada por el joven Enrico mientras su padre, el duque Anselmo, estaba en la guerra como general; de estos amoríos nació una niña y otro vástago venía en camino, al regresar de la guerra el anciano descubre su deshonra y muere lanzándole una maldición a Fidelina consistente en que sus propios hijos la matarían sin querer. A estos relatos sucederán soliloquios reflejos de Delfín y Linda mostrándose desdichados por su origen incierto e interpelando a su madre: así, se preguntará él “iquién eres tú?, ¿quién soy yo?” (p. 4) y ella "madre triste, ¿dónde estáis / robando mis alegrías?" (p. 8).

La segunda jornada desarrolla el ascenso y caída en desgracia del favorito, línea temática que ya había sido introducida al final del primer acto cuando el rey otorga a Delfín su merecido nombramiento como valido. A partir de este punto se van a conjugar con el conflicto central de la identidad una serie de elementos que relacionan esta pieza con el drama de privanza. Como señala Gonzalez, el principal punto de contacto con este género es la idea de precariedad que experimenta Delfín en su nueva condición de preferido del rey, pues teme desde un primer momento que esta bonanza sea frágil (Gonzalez 2009: 248). En este tipo de obras se observan también referencias a casos de ascensos osados que terminan con caídas funestas como los vuelos de Ícaro o Faetón, rasgo que se reitera en las comedias palatinas asentadas sobre la base de relaciones amorosas entre miembros de estamentos sociales contrapuestos. En El hijo de las batallas tenemos una imagen de este tipo en el monólogo en el que Delfín se queja por amor y advierte a su pensamiento atrevido por querer a Linda siendo villano:

si corres altanero,

mírate en las cenizas que han quedado,

$y$ en el cristal por suerte,

del que por atrevido vio su muerte (p. 12).

Y más adelante, cuando Delfín y el Almirante riñan por el guante de Linda, el segundo increpará al que "tan infame ha nacido" diciéndole: 
¿Tú te subes y te exaltas, y no mirando a tus faltas subes a esperanzas necias?

Corta las alas que precias, ya que naciste entre mallas (p. 14).

Como podemos apreciar, el nacimiento sin honor sigue abatiendo al protagonista aun cuando goza de la privanza. Ha podido disfrutar de los favores reales, pero se sigue considerando un desafortunado, y así expresa en otro pasaje su malhadado ascenso:

¿Qué importa que mi valor me levante a las estrellas, cuando conjuradas ellas muestran al son de mis dichas que son en poder desdichas, y de mi agravio centellas? (p. 14)

Y ante esto la figura de la mala madre vuelve a surgir como única depositaria de la culpa de la desgracia que el hijo de las batallas experimenta, aun cuando ha sido reconocido por la fuerza de sus obras. Como señala Gonzalez, Delfín es en este sentido un héroe que no puede evadirse de los condicionamientos de su sangre (Gonzalez 2009: 133). El retrato misterioso y aquellas tres letras enigmáticas lo angustian, y solo encuentra relativo consuelo en su otra madre, la espada. A ella se dirigirá pidiendo venganza tras la discusión con el Almirante, en la que nuevamente ha sido agraviado por su origen desconocido:

Entrad, y abone el partido, espada, el valor que cobras;

hijo soy de vuestras obras, por vos sola he merecido (p. 15).

En el enfrentamiento Delfín mata al Almirante, lo cual desencadena su caída en desgracia: ha muerto un noble a manos de un villano y los principales de Inglaterra se alzan contra el rey para que haga justicia. Ante esto no hay otra opción: Enrico debe juzgar como rey y quitar a su protegido de la privanza. Como podemos apreciar, en la comedia no solamente se escenifican los conflictos interiores de los personajes, sino que se desarrolla igualmente una línea de acción relacionada con el convulso momento político que vive 
el reino, en primer lugar, por la ya referida falta de heredero legítimo y por la guerra con Bohemia; $y$, en segundo término, por estos levantamientos internos de los nobles y también de los vasallos que claman justicia para que se castigue a los que creen traidores. De este modo, el trasfondo político que constituye la base de las comedias de privanza se comunica asimismo a este tipo de obras palatinas de temática grave que incorporan pinceladas acerca del ejercicio del poder y la inestabilidad de la fortuna asociada al mismo (Florit 1999: 72-73, Zugasti 2003: 167-169 y 176-179).

Así pues, el rey se ve obligado a hacer justicia: Delfín es apresado en una torre junto con el rey de Bohemia, que está allí cautivo tras su derrota. El privado ejemplar se rinde ante la decisión de su monarca y pide que lo mate para que el reino quede sosegado, no sin antes recordarle que no vio tan bravos a estos nobles cuando estaban en el campo de batalla, donde lo abandonaron a su suerte (p. 15). Por su parte, el gracioso Pinalvo anuncia el cambio de su propia fortuna, ya que cae en desgracia junto con su amo, haciendo una nueva referencia a la pareja cervantina: "que en muriendo don Quijote / ha de morir Sancho Panza” (p. 16).

En el espacio de la prisión tendrá lugar la parte más lúdica de la pieza y el mayor desarrollo del enredo. Linda, disfrazada de varón, adquiere la identidad de amigo incógnito de Delfín y procura liberarlo. Pero la intriga se complica pues rescata equivocadamente al rey de Bohemia. Delfín, por su parte, será liberado erróneamente por el envidioso Doricleo, quien en realidad quería excarcelar al rey enemigo por perjudicar a su hermano. Delfín, que es consciente desde un comienzo de la confusión, se descubre ante Doricleo una vez fuera de la torre. En este punto se apreciará otra vez la calidad virtuosa de este personaje ya que perdona a su hermano y le dice que marche a Londres a disfrutar de la privanza del rey, no sin antes espetarle esta sentencia: "yo perdono como noble, / tú ofendes como villano" (p. 20). Estos dos hermanos, figuras contrapuestas, ejemplifican otro rasgo de las obras de privanza en las que se balancean los destinos de dos favoritos, uno de los cuales, el negativo, traiciona movido por la envidia.

En la tercera jornada, ambientada en un bosque, aparece sorpresivamente un nuevo personaje, Fidelina; la culpable madre sale a escena "vestida de pieles, los cabellos tendidos” ( p. 19), caracterización que respondería, según la clasificación de Antonucci, al estado de salvaje que se adquiere por una transgresión a las reglas del vivir humano (1995: 52). Su estado de abandono es un trasunto de la culpa que la aqueja. El papel que cumple la madre en $E l$ hijo de la batallas difiere radicalmente del que posee este personaje en $E l$ hijo Venturoso. En la comedia de Lope, Clara es liberada del cautiverio por 
su hijo, se produce la anagnórisis y Venturoso le advierte que no la abrazará hasta que no recupere su honra, pues si ella no la tiene, él tampoco, y por ello la amenaza: "Madre: si queréis ser madre, / dadme padre; si no, adiós" (p. 101). Esto será posible porque Mauricio no se ha casado y Venturoso, capitán a cargo del sitio de Milán, goza de una posición de poder que le faculta para obligarlo a que se despose con Clara.

En el caso de la obra de Cordeiro, la presentación de la figura materna se da desde un comienzo marcada por la desgracia dado el efecto de la maldición trágica de Anselmo que pulula a lo largo de las primeras jornadas. Tanto Delfín como Linda se refieren a ella como razón de la infamia en la que viven. De este modo, en cuanto aparece en escena, el receptor intuye que este personaje ha de tener un destino fatal. Por otra parte, desde un punto de vista dramático sería imposible una restauración de la honra de Fidelina porque el rey ya está casado, tiene una reina; el personaje queda por lo tanto suelto y condenado a desaparecer. Para ello, Cordeiro introducirá el recurso del matricidio involuntario. Delfín, tras dejar que parta Doricleo, se recuesta junto a unos árboles; allí habla con el enigmático retrato de su padre y surge nuevamente la recriminación hacia su progenitora:

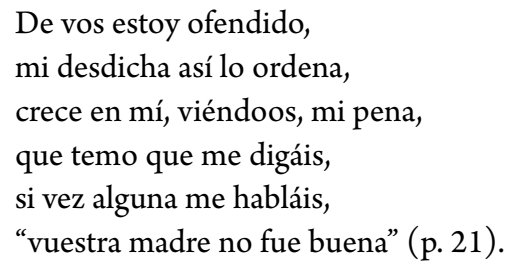

Entre tanto Fidelina lo observa escondida, extrañamente atraída hacia él, en una nueva aparición del motivo de la fuerza de la sangre. Delfín, que teme que en la montaña pueda ser víctima de un animal salvaje, cae finalmente vencido por el sueño. Fidelina se acerca a él para admirarlo y en ese momento, $y$ en medio de una pesadilla, el hijo de las batallas mata a su madre carnal con una pistola al confundirla con una fiera. La anagnórisis se produce con Fidelina agonizante, quien resuelve todas las dudas de su hijo en su momento final: su padre es el rey Enrico, tiene una hermana llamada Linda y su abuelo Anselmo era noble; por lo tanto, según su madre, tiene el derecho y el deber de cumplir el mandato de aquellas letras enigmáticas, “T P B”, “Tu padre busca” (p. 21), y convertirse así en heredero del trono de Inglaterra.

Delfín consigue de este modo acceder a la información que ha estado buscando desde el inicio de la obra, y lo hace en el duro trance de la pérdida 
de la madre recién encontrada. No obstante, el tono dramático que cobra este fragmento de anagnórisis mortal es limitado. Tras unos pocos versos de manifestación dolorosa el sentido de la acción vuelve a cambiar alejándose de la fatalidad. En el momento en el que Delfín intenta suicidarse con su espada, suenan cajas de guerra que lo distraen de su objetivo. Nuevamente se activa en el protagonista su impulso marcial, esta vez relacionado con una militia amoris. Quien entra como guerrera es Margarita, la infanta de Bohemia, que lo reconoce como vencedor valeroso de su hermano. Delfín se postra ante ella cortésmente y ella cede y lo nombra general de sus huestes. Ambos entablan una dinámica en la que amor y guerra van a combinarse, lo que acerca a esta pieza, en este punto preciso, a la sintonía amorosa propia de la comedia palatina más pura. Lo mismo sucederá más adelante con Linda y el rey de Bohemia en un pasaje, eco de este, en el que Linda saca la espada para matarlo y él cae rendido ante ella por las gracias de la dama antes que por las armas. Como podemos apreciar, existe un claro contraste entre el segmento trágico de la muerte de Fidelina y estos dos momentos inmediatamente posteriores en los que el tono se inclina hacia el enredo de galanteo amoroso. En medio de estos requiebros y de los sones de la batalla se dispone el túmulo funeral de Fidelina, rodeado por veinte antorchas.

En el siguiente bloque la acción se sitúa en la corte. Londres vive una situación de crisis total con sublevaciones internas y con el peligro de la inminente guerra con Bohemia, que ahora cuenta con Delfín en su bando. El hijo de las batallas irrumpe en escena a caballo (p. 26) ${ }^{18}$ mostrando en este elemento caracterizador de nobleza un cambio de rango: ahora se sabe también heredero natural del reino. En este punto el héroe ha de aportar orden en el caos: resuelto su conflicto interno, le toca traer la armonía al plano político. Así se dirige a los sublevados y les descubre la confusión en la que viven inmersos en la ceguera de la envidia y las pasiones. Llega además como embajador del ejército de Bohemia y como tal se ofrece a poner coto a la rebelión interna. A partir de este momento se aceleran los acontecimientos: el traidor se descubre (Doricleo), se reconocen los inocentes (Delfín y también el duque Florando, que había sido culpado de dejar escapar al rey de Bohemia), se completa la anagnórisis familiar para el protagonista con el rey, quien lo declara su heredero, y se anuncian las bodas que traerán la paz

18 No se indica en la acotación si se trata de un caballo de artilugio. Según señala Vega García Luengos (2011: 251), existen abundantes referencias a caballos en el teatro aurisecular en el nivel dramático, pero no tantos caballos en escena. En este caso podría suponerse la presencia de un equino real considerando la variedad de recursos presentes en esta pieza, y sobre todo habría sido posible en la representación de Coimbra (1625), llevada a cabo en la calle y en un marco festivo. 
al reino: Delfín con Margarita y Linda con el rey de Bohemia. Se cierra así la pieza con una armonía en todas las facetas, públicas y privadas.

\section{Conclusión}

En definitiva, cabe concluir que El hijo de las batallas reúne motivos y temáticas procedentes de la comedia palatina y del drama de privanza, formando un todo difícil de encajar en una taxonomía estanca. Estamos ante uno de esos casos en los que se hace evidente la hibridez genérica a la que se presta la comedia palatina. Por otro lado, esta es una pieza en la que se acumulan recursos escénicos y dramáticos. Nos encontramos con maldiciones, escenas bélicas, rebeliones, riesgo de incesto, intento de suicidio, representación del salvaje, una pesadilla que lleva a un matricidio... además de los recursos propios de la comedia de enredo: papeles, enigmas, retratos, la dama vestida de varón... Seguramente esta variedad de procedimientos teatrales es lo que llevó al Conde de Schack a plantear que esta pieza mostraba una imaginación grande por parte de su autor, "aunque extraviada" ${ }^{19}$. Gonzalez indica que esta obra podría ser incluida en la categoría que Corneille denominó "comedia heroica" (Gonzalez 2009: 253). Estamos, sin duda, ante el desarrollo del periplo vital de un héroe -en un marco palatino- que sufre por su pérdida de identidad, se hace hijo de sus obras, experimenta las veleidades de la privanza, se convierte en matricida y luego en heredero de un reino.

Ante esto cabe preguntarse si esta obra de Jacinto Cordeiro podría ser clasificada como trágica. Si consideramos que lo trágico se fundamenta en el efecto que suscita en el espectador (Vitse 1988: 308, Arellano 2011: 16), podría pensarse que estamos ante una comedia seria que alcanza ribetes de tragicidad únicamente para el personaje de Fidelina, cuya muerte, como señala uno de los personajes, es entendida barrocamente como "peregrino suceso" y "notable maravilla" (p. 28). No hay en la globalidad de la pieza una sensación trágica para el receptor. Delfín consigue el objetivo que se plantea: conocerse y ser reconocido por los otros; al medio ha mostrado su valía individual y su virtud construyendo su ventura, lo cual, unido a su nobleza heredada, lo transforma en un héroe ejemplar en el que se aúnan el poder de las obras con el poder de la sangre.

19 Citado en Cruz Ortiz 2013: 6. 


\section{Bibliografía}

ANTONUCCI, Fausta (1995). El salvaje en la comedia del Siglo de Oro: historia de un tema de Lope a Calderón. Pamplona: Universidad de Navarra.

ARELLANO, Ignacio (2005). “Teatro del Siglo de Oro en Indias. La 'zarzuela' de la purificación de Potosí (Convento de Santa Teresa)”, Revista de Literatura, 133, 193-209.

ARELLANO, Ignacio (2011). "Lo trágico y lo cómico mezclados y mixturas en el teatro del Siglo de Oro”, Rilce, 27.1, 9-34.

ARES MONTES, José (1992). “Bodas y divorcio del teatro hispano-portugués”, in Actas Dramaturgia e Espectáculo. Coimbra: Livraria Minerva, 49-55.

ALDOMÁ GARCÍA, Mireia (1996). “Los Hecatommithi de Giraldi Cinzio en España”, in Ignacio Arellano, María Carmen Pinillos, Frédéric Serralta y Marc Vitse ed. Studia Aurea. Actas del III Congreso de la AISO, Pamplona: GRISO-LEMSO, t. 3, 15-21.

CERVANTES, Miguel de (1998). Don Quijote de la Mancha, ed. dirigida por Francisco Rico. Barcelona: Instituto Cervantes/Crítica.

CORDEIRO, Jacinto (s. a.). El hijo de las batallas. Comedia famosa del alférez Jacinto Cordero, Sevilla: Imprenta Real, Casa del Correo Viejo, <http://fondosdigitales.us.es/fondos/ libros/4913/2/el-hijo-de-las-batallas-comedia-famosa/>

CORDEIRO, Jacinto (1999). La privanza merecida, ed. Giancarlo Depretis. Torino: Edizioni de'll Orso.

CRUZ ORTIZ, Jaime (2009). "Lealtades divididas: las alianzas literarias y políticas del dramaturgo portugués Jacinto Cordeiro”, in Judith Farré ed., Dramaturgia y espectáculo teatral en la época de los Austrias. Madrid: Iberoamericana, 95-105.

CRUZ ORTIZ, Jaime (2010). "El poeta lisboeta Jacinto Cordeiro y la comedia portuguesa”, in Aurelio González, Serafín González y Lilian von der Walde Moheno ed., Cuatro triunfos áureos y otros dramaturgos del Siglo de Oro. México: El Colegio de México/Universidad Autónoma Metropolitana/AITENSO, 331-344.

CRUZ ORTIZ, Jaime (2013). “Estudio preliminar a Cordero, Jacinto, El juramento ante Dios $y$ lealtad contra el amor. A Modern and Critical Edition”. Nueva York: Peter Lang.

CHECA, Jorge (2011). “Engendrado por la guerra: El hijo Venturoso de Lope de Vega”, Bulletin of the Comediantes, 63.1, 1-17.

EICHMANN, Andrés (2005). "Notas sobre el teatro en Charcas", in Normas Campos ed., Manierismo y transición al Barroco. La Paz: Artes Gráficas Sagitario, 333-343.

ESPINO LÓPEZ, Antonio (2001). Guerra y cultura en la época moderna. Madrid: Ministerio de Defensa.

FERRER, Teresa et al. Base de datos de comedias mencionadas en la documentación teatral (1540-1700). CATCOM, <http://catcom.uv.es>

FLORIT, Francisco (1999). “El vergonzoso en palacio: arquetipo de un género”, in Ignacio Arellano y Blanca Oteiza eds., Varia lección de Tirso de Molina. Pamplona/Madrid: Instituto de Estudios Tirsianos, 65-83. 
GARCÍA HERNÁN, David (2006). La cultura de la guerra y el teatro del Siglo de Oro. Madrid: Sílex.

GAYTÁN DE VOZMEDIANO, Luis (1590). Primera parte de las cien novelas de Juan Baptista Giraldo Cinthio. Toledo: Pedro Rodríguez.

GIRALDI CINTHIO, Giovanni (1834). Ecatommiti, In Raccolta di novellieri italiani. Firenze, Tipografia Borghi e Compagni.

GLENN, Richard F. (1973). "The Loss of Identity: Towards a Definition of the Dialectic in Lope's Early Drama”, Hispanic Review, 41, 609-626.

GONZALEZ, Christophe (1987). Le dramaturge Jacinto Cordeiro et son temps (Thèse). Provence: Université de Provence.

GONZALEZ, Christophe (2002). "De la Comédie espagnole aux textes anti-castillans, l'itinéraire d'un dramaturge portugais entre la Monarchie dualiste et la Restauration: Jacinto Cordeiro", Arquivos-Centro Cultural Calouste Gulbenkian, 44, 183-197.

GONZALEZ, Christophe (2009) "Du village au palais, le parcours identitaire de El hijo de las batallas, de Jacinto Cordeiro: matricide, question du père et risque d'inceste”, in Mónica Güell y Marie-Françoise Déodat-Kessedjian eds., À tout seigneur tout honneur. Mélanges offerts à Claude Chauchadis. Toulouse: Universitè Toulouse II-Le Mirail, 243-253.

GONZALEZ, Christophe (2012). "Un cas de tyrannicide sur la scene baroque iberique: $E l$ Mal Inclinado, une piece de Jacinto Cordeiro”, Reflexos, 1-10.

HUARTE DE SAN JUAN, Juan (1989). Examen de ingenios, ed. Guillermo Serés. Cátedra: Madrid.

INSÚA, Mariela (2011). "Amor y poder en Lo que es privar, comedia del alférez lisboeta Jacinto Cordeiro", in Colóquio Letras. Suplemento Siglo de Oro. Relações hispano-portuguesas no século XVII. Lisboa: Fundação Calouste Gulbenkian, 67-76.

INSÚA, Mariela (2012). "Aspectos del poder en la bilogía Próspera y Adversa fortuna de Duarte Pacheco de Jacinto Cordeiro”, Estudos Ibero-Americanos, 38.1, 186-199.

INSÚA, Mariela (2015). "Mecanismos del secreto en El secretario confuso de Jacinto Cordeiro", Hipogrifo. Revista de literatura y cultura del Siglo de Oro, 3.2, 165-178.

MORLEY, S. Griswold; Bruerton, Courney (1968). Cronología de las comedias de Lope de Vega. Madrid: Gredos.

OLEZA, Joan (1986). "La propuesta teatral del primer Lope de Vega”, in Joan Oleza ed., Teatro y prácticas escénicas, II: la comedia. London: Tamesis Books, 251-308.

OLEZA, Joan; Antonucci, Fausta (2013). “La arquitectura de géneros en la Comedia Nueva: diversidad y transformaciones", Rilce, 29.3, 689-741.

OLEZA, Joan et al., Base de Datos y Argumentos del teatro de Lope de Vega. ARTELOPE, <http://artelope.uv.es>.

PASCA, Giovanni Battista (1669), Il figlio della battaglia. Napoli: Bartolomeo Nicola Moreschi.

TEMPLIN, E. H. (1934). “The source of Lope de Vega's El hijo Venturoso and (indirectly) of La esclava de su hijo", Hispanic Review, 2.4, 345-348. 
VEGA, Lope de (1993). El hijo Venturoso, in Comedias III. Madrid: Turner/Biblioteca Castro.

VEGA GARCÍA LUENGOS, Germán (2011). "Hipogrifos violentos y otros caballos calderonianos”, in Elisa García-Lara y Antonio Serrano (ed.), XXIV y XXV Jornadas de teatro del Siglo de Oro. Almería: Instituto de Estudios Almerienses, 237-256.

VITSE, Marc (1988). Éléments pour une théorie du théâtre espagnol du XVII siècle. Toulouse: Université de Toulouse le Mirail.

ZUGASTI, Miguel (2003). “Comedia palatina cómica y comedia palatina seria en el Siglo de Oro”, in Eva Galar y Blanca Oteiza eds., El sustento de los discretos. La dramaturgia áulica de Tirso de Molina. Madrid/Pamplona: Instituto de Estudios Tirsianos, 159-185. 



\title{
La erudita bufonería de La pícara Justina. Algunas notas
}

\section{The erudite buffoonery of La picara Justina. Some annotations}

\author{
IgNACio ARELlano \\ Universidad de Navarra - GRISO \\ iarellano@unav.es
}

Texto recebido em / Text submitted on: 4.09.2015

Texto aprovado em / Text approved on: 28.09.2015

Resumen: Se proponen explicaciones a varios pasajes y expresiones de La pícara Justina de Francisco López de Úbeda, hasta ahora no aclarados satisfactoriamente en las ediciones de la obra, que juegan burlescamente con referencias eruditas, en un ejemplo de intertextualidad característicamente bufonesca.

Palabras clave: bufones, ingenio, erudición jocosa, anotación de textos, La pícara Justina

Abstract: The paper proposes explanations to several passages and expressions of La pícara Justina by Francisco López de Úbeda, up to now unsolved in editions of the work, which mockingly plays with erudite references, in an example of intertextuality characteristically buffoonish.

Keywords: buffoons, wit, playful erudition, text annotation, La pícara Justina

El Libro de entretenimiento de la pícara Justina (1605) es seguramente uno de los más difíciles de todo el Siglo de Oro, en su acumulación bufonesca de juegos, cuentecillos, alusiones, disparates y excesos carnavalescos... Dos ediciones recientes (Luc Torres, 2010; David Mañero, 2012) ofrecen un copioso aparato de explicaciones, notas y comentarios que un lector sensato no puede menos que agradecer.

Este tipo de obras que tanto apelan al ingenio retan al lector, proponen una tarea de desciframiento compleja, una diversión "especulativa" y un desafío para lectores meticulosos. En semejante tejido de chistes, alusiones y enigmas nada de extraño tiene que siempre queden algunos nudos de la red por desenlazar.

Algunos de estos pasajes que permanecen oscuros a los editores y comentaristas me propongo tratar en estas breves notas, como contribución parcial 
en este camino de desciframiento de las ingeniosas y eruditas referencias de La picara Justina.

\section{Terlincampuz}

El abuelo suplicacionero de Justina tuvo muchas habilidades, entre otras "fue el que inventó el echar la buena barba y compuso el terlincampuz de tabla a tabla” (Mañero: 328-329; Torres: 217-218). ¿Qué es ese terlincampuz? Para Torres (939) repicar un terlincampuz es "'amonestar, reñir al pagano. Cfr. cantar el salmo de Herlincampus, grabado en espadas (Correas [...])"; y para Mañero, que cita a Puyol y Alonso "parece ser $[. .$.$] una arenga o recitación$ que acompañaba a un juego o suerte de titiritero".

Es cierto que en Correas se recoge la expresión "Cantarle el salmo del Herlincampus. Reñir a uno y amonestarle. Herlincampus es nombre tomado a burla de los escritos en espadas extranjeras" (refrán 4482, con parecida formulación en el 4491), pero el contexto de La pícara apunta a otro sentido y otra variante más cercana a la lectura de Mañero que a la de Torres. La expresión "echar la buena barba" es un "juego de suplicacioneros [...] por alusión se dice de los que con arengas compuestas y lisonjeras sacan a uno sus dineros" (Covarrubias): es decir, alude a la charlatanería profesional de los vendedores de barquillos o suplicaciones y prestidigitadores. El terlincampuz es algo semejante, una especie de conjuro mágico más bien jocoso, que los suplicacioneros decían en los juegos y apuestas para vender o sortear sus barquillos. Baste recordar aquí el comentario de Lorenzo Osorio en su Piña de rosas ${ }^{1}$ :

otras especies [de engaños y adivinaciones] que no son tan malas, como son los juegos de burlas que llamamos embaidores, que es arte para engañar a los bobos y a los ignorantes, y hoy día usan y mal, y en lo que hablan y hacen estos embaidores se echa de ver ser todo burla, y siendo yo muchacho, por oírles decir terlinquinpas, terlinquinpus, cascos de calabaza, pelos de ratón, les di hartos cuartos (243-244)

Calderón en el entremés de El dragoncillo, usa la variante quiririnquinpuz en un conjuro fantástico:

Lo cita Rodríguez Marín 1922: 372, y el mismo comenta las variantes quiririnquinpuz, quirlinquinpuz en p. 307. 
Soldado Quiririn quin paz.

Gracioso Quiririn quin paz.

Soldado Quiririn quin puz.

Gracioso Quiririn quin puz.

Soldado Aquí el buz.

Gracioso Aquí el buz.

Soldado Allí el baz.

Gracioso Allí el baz.

Soldado Tras.

Gracioso Tras.

Soldado Tris.

Gracioso Tris.

Soldado Tros.

Gracioso Tros.

Soldado Trus.

Gracioso Trus.

Soldado Quirilín quin paz, quirilín quin puz.

Gracioso Quirilín quin paz, quirilín quin puz

(Calderón, El dragoncillo: 273-274).

Y también en la comedia burlesca del mismo Calderón, Céfalo y Pocris, en contexto que aclara la expresión como perteneciente a la jerga de los prestidigitadores:

dije, como jugador

de manos: "Quirlinquinpuz” (vv. 1526-1527)

\section{El dedo del gigante}

Supone Justina que un lector curioso le pide noticias de sus andanzas el tiempo que vivió con su madre, y accede a regañadientes a narrar un poco, aunque no todo, aduciendo una alusión al dedo del gigante (lib. I, cap. 3):

¿Qué vida quieres que cuente, sabiendo que bailaba al son que me hacía mi madre? Ea, déjame, no me importunes, igentil disparatón! [...] Pues si tanto me importunas, habré de pintar algo, aunque no sea sino el dedo del gigante, que por ahí sacarás quién fue Calleja.

Los editores más modernos no acaban de sacar a Calleja por el dedo, porque no ven claro qué dedo ni qué gigante es ese. Luc Torres escribe (289, 
n. 422): "habré de deshacer la madeja, aunque sea solo tirando de un hilo; hilo de la madeja=dedo del gigante", con un comentario muy poco satisfactorio, insatisfacción que aumenta con su nota sobre Calleja en la que vuelve a dar una explicación poco resolutiva, documentando el nombre de Calleja y mencionando al padre Diego Calleja, jesuita del XVII, autor de alguna que otra comedia $(289$, n. 423$)$ :

sacarás quién fue Calleja: 'sacarás la verdad, el busilis', y 'huirás de la justicia' (Germanía, p. 141/ Léxico, s. v. con nota erudita). Es nombre propio que aparece en la lengua en 1250 (Corominas, s. v. calle). Cfr. el padre Diego Calleja y su comedia sobre san Alejo ${ }^{2}$

David Mañero (409, nn. 237 y 238) señala que es una expresión que usa Lope en La santa liga:

mal conoces a Pío quinto, pues haz cuenta que te pinto solo el dedo del gigante.

pero no añade más, y en cuanto a Calleja recuerda pertinentemente su presencia folklórica en refranes como los que recoge el maestro Gonzalo Correas: "Hemos de ver quién es Calleja; habemos de ver quién es Calleja"; "Habemos de saber quién es Calleja".

Lo que hay en La pícara Justina es una mezcla característicamente bufonesca de motivos de la tradición clásica, bebidos en repertorios, polianteas y margaritas, -cuando no en la fuente directa-, y otros populares y folklóricos. Lo de Calleja vale con lo que dice Correas. Para el dedo del gigante añádanse unas pocas referencias.

La anécdota tiene su origen último, supongo, en la Historia natural de Plinio, que la recoge en el libro 35, cap. 10, en una serie de ejemplos de dificultades solucionadas con habilidad por varios pintores. Timantes encontró una ingeniosa solución para pintar una figura grande en un lienzo pequeño, poniendo

2 No se ve porqué habría de huir de la justicia el lector -a quien se dirige Justina-, y el P. Calleja nace en 1639, mucho después de haberse escrito La pícara Justina; aunque Torres no señale que el Calleja citado tenga que ver con el jesuita y solo quiera documentar el nombre, la referencia es arbitraria en este caso. 
un cíclope durmiendo pintado en una tabla pequeña, del cual deseando declarar allí su grandeza, pintó junto a él unos sátiros que le medían el dedo grueso con un bastón...

La anécdota debió de hacerse lugar común en los tratados de pintura: la hallamos en Leon Baptista Alberti, Tratado de la pintura; Timantes

pintando a un cíclope dormido en una tabla pequeña, lo puso al lado de unos sátiros que le abrazaban el dedo gordo del pie, para que pareciese su estatura enorme comparada con la de los sátiros (Alberti 1990: 215).

El pasaje de Plinio tiene dos lecturas variantes: una es la que parece corresponder a los pasajes citados y en la que insiste Butrón en sus Discursos apologéticos en que se defiende la ingenuidad del arte de la pintura, donde menciona dos tablas diferentes, una en la que Timantes pintó a Polifemo, y otra en la que pintó a un cíclope dormido al que los sátiros le medían el pulgar:

Pintó también en pequeña tabla a Polifemo con los sátiros y el juicio de las armas de Ayax [... Pintó un Cíclope dormido: para denotar su grandeza pintó allí unos sátiros que le medían el dedo pulgar (116)

Butrón toma el pasaje correspondiente de la Mitología de Natale Conti (Mitología, 567), donde dice exactamente lo mismo que Butrón copia casi a la letra.

El motivo aparece de nuevo en el primer tratado de pintura escrito en Nueva España, El arte maestra de José de Ibarra:

pintando este un dormido cíclope en un pequeño lienzo, le pintó cerca unos sátiros intentando abrazarle el dedo grueso; con esta figura aunque la imagen del cíclope era pequeña, parecía del todo grande (Soto 2005: 133-134).

En esta lectura la ingeniosidad de Timantes consiste en ser capaz de evocar la grandeza de un cíclope en un pequeño lienzo, colocando figuras más pequeñas que den idea de la proporción.

Otra interpretación (la que se evoca en La pícara Justina) la encontramos no solo en el texto de Lope aducido, sino en otros varios, según la cual Timantes habría pintado solo un dedo del gigante, de cuyo tamaño podría deducirse el de la figura completa ${ }^{3}$. El Inca Garcilaso de la Vega, en su Florida del Inca parece tener en mente esta segunda variante:

\footnotetext{
3 Sería una variante de ex ungue leonem 'por la uña se saca el león'.
} 
Por esto poco que hemos contado que pasaron en esta breve jornada, se podrá considerar y ver lo que los demás españoles habrán pasado en conquistar y ganar un nuevo mundo, $[\ldots]$ y por el dedo del gigante se podrá sacar el grandor de su cuerpo, aunque ya en estos días los que no han visto, como gozan a manos enjutas del trabajo de los que lo ganaron, hacen burla dellos (272).

\section{Pedro de Solís y Valenzuela en su obra El desierto prodigioso y prodigio del} desierto lo comenta con más detalles y proporciona la clave de la referencia:

Pidiéronle a Timantes, el más célebre pintor que tuvo la Antigüedad, que en un breve lienzo pintase un gigante de descompasada estatura; y reconociendo el empeño por dificultoso, dio en un sazonado arbitrio: pintó en el lienzo solo un dedo del gigante y unos hombres como hormigas que con varas proporcionadas a sus cuerpos le estaban midiendo, para que así, desta disparidad tan grande pudiese formarse la idea de lo que sería el gigante. Así yo, para hacerte un paréntesis breve de lo que es esta santa Casa del Paular, solo he pintado un dedo del gigante, solo te he dibujado al portero... (II, 797)

Juan de Espinosa Medrano, el famoso Lunarejo, lo adapta a lo divino en su sermón "Antonio el Magno", donde el predicador se compara a aquel "pintor famoso" a quien se le pidió que pintara un cíclope, y siendo el gigante demasiado grande para pintarlo completo, solo pintó un dedo:

mal podré yo delinear toda la admirable magnitud de Antonio el grande, Gigante soberano de la Iglesia de Dios [... Mucho seré si acierto a dibujar un dedo, $[\ldots]$ pásmense pues esos espíritus réprobos de ver tan valiente dedo $[\ldots]$ Midan pues, midan con asombro el dedo de ese jayán; tiendan las cuerdas de su poderío, que con horror admirarán $[. .$.$] ya lo veis, aunque con pincel grosero,$ si no con rústica pluma delineado; que esto, Señor, es haber dibujado solo el dedo de el Gigante, lo demás de su inmensa corpulencia, y magnitud [...] no le es concedido a la humana comprensión ${ }^{4}$.

Y a lo divino lo usa el padre García en su biografía de San Francisco Javier:

Pensará alguno que he dicho mucho y si lo piensa es señal que yo no he dado a conocer a Javier. No le lograra la industria de Timantes si los que vieran a los sátiros medir el dedo de el gigante pensaran que no era mayor el gigante que el dedo [... Yo he pintado un dedo solamente para que se conozca por él su estatura (402) ...

Pues este es el dedo del gigante que la pedantesca Justina saca a colación.

4 Ver Acuña, "Juan Espinoza Medrano y el motivo de San Cristóbal”. 


\section{¿Hace cala o acecala?}

Hay enojillos, dice Justina, que "son agua de fragua y ceniza que hace cala para que corte la espada"s. Las notas que ponen los editores son: "Cala: probablemente se refiere a la operación del temple; el adjetivo calado, da, se empleó también en equivalente de sutil o perspicaz (Puyol, [... ]" (Damiani: 229); "cala: según P. A. [... ] se refiere a la operación del temple" (Mañero); “cala (hacer), 'templar' (Aut., s. v.)” (Torres, en el Glosario, 886, con una definición que no hallo en Autoridades).

Me barrunto que el texto no debería editarse como se hace usualmente "hace cala", sino "acecala", del verbo acecalar o acicalar:

[ACECALAR]. Azecalar. Vale tanto como limpiar y dar lustre al acero, y así acecalamos las armas y particularmente las espadas, que limpiándolas no solo les damos lustre y resplandor, mas aun les ponemos más filos. (Covarrubias)

\section{La cola de la serpiente}

En un episodio del libro II, II, cap. 2 desea Justina ser cantadera, y en un diálogo con un mancebo algo impertinente le dirige un insulto alusivo a la cola de la serpiente:

- A lo menos, si vos no sois cantadera, teneis gesto de encantadera.

No se fue riendo, que yo le dije a él:

Alusión a las colas de las serpientes.

- Si yo soy encantadera, tápate con la cola, pues te sobra, asnazo.

Anota Torres (sin nota en otras ediciones):

'Si yo soy encantadera tú eres un burro', jugando con el cazurrismo de cola 'penis' (468)

Pero no hay alusión cazurra, sino más bien emblemática referida a las creencias sobre las habilidades de los animales. En la misma Pícara Justina -en buena parte compuesta de jeroglíficos- se halla la explicación de la práctica atribuida a las serpientes de taparse un oído con la cola para evitar los efectos de los conjuros: comp. Preliminares ${ }^{6}$ :

\footnotetext{
Mañero, 568; Torres, 441 igual lectura. No hallo la referencia de Autoridades que aduce Torres.

6 Ver p. 259-260 ed. Mañero; 164-166 ed. Torres, que en este pasaje sí anota bien el sentido, por otra parte explicado en el mismo texto.
} 


\section{Propriedad de la culebra.}

La culebra, para no dar a la muerte franco el postigo de los oídos, por donde el encantador la guía, cose el un oído con el suelo, y el otro zúrcele con la cola [...] con los que os cantaren con lisonja o sin lisonja, haréis lo que la culebra, cosiendo el un oído con el suelo de humildad y el otro con la cola de despedida.

El motivo es muy conocido en repertorios de emblemas: ver Covarrubias, s. v. culebra: "Y es cosa recebida comúnmente cuando los hechiceros quieren encantarla, apretar la una oreja con la tierra y cerrar la otra con la cola por no oír sus palabras según lo describe David, Psal. 55: "Sicut aspidis surdae et obturantes aures suas quae non exaudiet vocem incantantium et venefico incantantis sapienter”“. Como señala Ripa (Iconología, I, 272), la imagen también se encuentra en el salmo 57, 5-6. Malaxecheverría 1986: 184: “ [el áspid] tapona perfectamente sus oídos: oprime uno contra el suelo y en el otro mete la cola con firmeza para no oír nada", o 185-186: "en cuanto oye la música $[. .$.$] obtura una de sus orejas con el extremo de la cola y frota la otra$ en tierra". Un emblema de Camerarius (Symbolorum et emblematum ex aquatilibus et reptilibus desumptorum centuria quarta, 1604) representa con mucha exactitud al áspid en esta práctica (ver Henkel-Schone 1976, col. 641).

Lo que hay es una dilogía en cola 'cola de serpiente' y 'cola de burro'.

\section{El arca de Noé}

Algunos de los motivos del ingenioso conceptismo pueden mostrar dos caras: el contexto definirá cuál es la aceptable. Una de las referencias al arca de Noé es entendida por los editores como alusión tópica que a mi juicio no funciona en el contexto preciso del lib. II, II, cap. 2 (Mañero: 604; Torres: 478): una de las tretas de la pícara consiste en apoderarse de un agnusdéi de oro que sustituye por otro sobredorado que lleva en la manga de su vestido:

Desato de mi rosario el agnusdéi de plata sobredorado, el cual guardé en la manga de mis cuerpos que para secretaria era tan buena como una de un fraile francisco, de las que llamamos las damas arca de Noé.

El recuerdo del chiste tópico de disociación Noé 'no he, no tengo' arrastra a las notas de los editores: "de Noé: vacía; no he [=no tengo]" (Mañero: 604); "arca de Noé: calambur por 'arca vacía. Cfr. No he=nada" (Torres: 478). Si se repara en el texto la pícara compara sus mangas con las de los 
frailes mendicantes, que las usan como zurrones. El sentido es el contrario del que proponen los anotadores, no 'manga vacía' sino 'manga usada como recipiente para meter muchas cosas'.

En efecto, hay otro sentido de arca de Noé, que se activa en el contexto citado, y que trae Covarrubias: "Arca de Noé solemos llamar la que tiene en sí muchas cosas y diversas", o Aut: "Arca de Noé. Se suele llamar por alusión a cualquiera cajón o cofre donde se encierran muchas y varias cosas y baratijas".

Es la misma significación que vuelve a usar Justina más adelante:

mi criado y yo habíamos metido en las alforjas más especies de cosas que cupieron en el arca de Noé. (La pícara Justina, 810 ed. Mañero).

\section{La hermana de Abraham}

En una cínica disertación sobre el disimulo Justina pone ejemplos de santas hipocresías, como la de Ester, que fingió delante del rey Asuero estar tan débil que no podía tenerse en pie (Ester, cap. 5), o la de "la mujer de Abraham" que "fingió que era su hermana" (Mañero: 606; Torres: 481).

Las ediciones modernas yerran en la identificación del pasaje último. Torres cree que es "alusión jocosa al hecho de que Sara, la mujer de Abraham, tuvo que aceptar las relaciones de este con su criada egipcia Agar (Génesis, XVI)", lectura que acepta Mañero.

Pero Justina se refiere a otro episodio, el de los peligros de Abraham en Guerar, narrados en Génesis, 20, 1-7:

Del lugar donde estaba partió Abraham a la tierra del Neguev, acampó entre Cades y Shur, y habitó como forastero en Gerar. Allí Abraham decía de Sara, su mujer: "Es mi hermana".

Entonces Abimelec, rey de Gerar, envió por Sara y la tomó. Pero Dios vino a Abimelec en sueños, de noche, y le dijo: "Vas a morir a causa de la mujer que has tomado, la cual es casada y tiene marido".

Pero como Abimelec no se había llegado a ella, le respondió: "Señor, ¿matarás también al inocente? ¿No me dijo él: "Mi hermana es", y ella también dijo: "Es mi hermano"? Con sencillez de mi corazón y con limpieza de mis manos he hecho esto". 


\section{Las revueltillas de San Antón}

El tejido verbal de La pícara Justina salta de las referencias bíblicas a la erudición clásica, y de los repertorios emblemáticos a las prácticas populares. En la visita al humilladero del lib. II, II, 4,

dimos nuestra vueltas alderredor como si fuera casa de San Antón, aunque desto no hay de qué hacer escrúpulo, porque en aquella tierra hay tantos volteantes de obligación que para ellos cada día es de San Antón para bien hacer y bien voltear. (Mañero: 707)

La nota de Torres (584) confunde distintos motivos antonianos que no aclaran el texto:

a san Antonio se le representa tradicionalmente delante de su ermita, solo acompañado por un puerco, porque los monjes antonianos criaban cerdos para utilizar su grasa en la cura del llamado fuego de san Antón o mal de los ardientes, que era un herpes zóster o ergotismo [...] Las vueltas alrededor de la casa de san Antón podrían ser alusión al mal de los ardientes. Por otra parte en la Villa y Corte de Madrid, ya en el siglo XVII, a lo largo de las calles de Hortaleza y Fuencarral, el día de san Antón (17 de enero) se celebraba una ceremonia llamada vueltas de san Antonio donde desfilaban caballeros con sus monturas ricamente enjaezadas...

Y Mañero (707) no identifica la costumbre ("no queda clara la tradición festiva aludida”), remitiendo a la nota de Torres, que es, ciertamente, algo confusa.

La tradición es muy conocida en algunas regiones, y se llama habitualmente "las revueltillas de San Antón". El día de San Antón, patrón de los animales, se imparte la bendición a los animales, que giran por tres veces (las tres revueltillas) en torno al lugar donde se sitúa el sacerdote.

La ceremonia se mantiene en bastantes lugares de la geografía española, por ejemplo en Navalvillar de Pela (Badajoz) ${ }^{7}$, y en toda la Ribera de Navarra, como recuerda Ricardo Fernández Gracia ${ }^{8}$.

Ver http://www.laencamisa.es/inicio/la-fiesta/el-origen/la-fiesta-de-san-anton-en-navalvillar-de-pela/

8 Ver http://www.unav.edu/web/facultad-de-derecho/detalle-opinionprofesores2/2014/01/19/ fiesta-e-imagenes-en-torno-a-san-anton?articleId $=3699045$. Yo mismo he asistido varias veces a las revueltillas de San Antón en mi población natal de Corella (Navarra). 
El 17 de enero se bendecían tanto alimentos, el famoso pan del santo, marcado con la tau, así como cereales y piensos para los animales y en muchos casos a los propios animales. José María Iribarren dio buena cuenta de numerosos festejos. Las hogueras de la víspera han sido una constante en numerosas localidades, así como el desfile delante de las imágenes del santo y de las hogueras. Las revueltillas en torno a sus pilares o ermitas se practicaban en la zona Media y la Ribera, mientras en la merindad de Sangüesa los animales desfilaban bajo una estola cogida en sus extremos de balcón a balcón, mientras el sacerdote procedía a la bendición. En Fitero, un curioso bando de 1818 ordenaba que "ninguno sea osado de llevar las caballerías corriendo por las calles con motivo de las vueltas que acostumbran dar por los San Antonios, a fin de evitar las desgracias que pueden ocurrir y al que quisiere salir se le encarga lleven aquellas al paso natural, bajo la pena al que contraviniere de tres días de cárcel y las costas de prisión y carcelajes".

\section{Momo, don Alonso y la fábrica humana}

La mesonera Sancha la gorda, incitada por las razones de Justina, cuenta a esta toda su vida y milagros, sin dejar nada en el tintero:

si todas las mujeres tuvieran tan buen desportaje no se quejara el Momo ni don Alonso de la fábrica humana, ni retara la falta de no haber puesto Dios vidriera al lado del corazón por donde se vieran sus secretos... (Mañero: 763; Torres: 644-645)

Torres recuerda oportunamente la alusión al dios Momo que propuso que el pecho del hombre tuviera una puerta para ver sus sentimientos, pero desvía el buen sentido en la anotación que pone a don Alonso, la cual contamina la explicación incompleta relativa a Momo, quedando el texto poco comprensible:

ni don Alonso: 'ni don Alonso el Casto'; alude al rey bajo cuyo reinado se descubrió la tumba del apóstol Santiago, "el cual edificó el templo en nombre del apóstol Santiago" [...]. Irónico, dado el sentido moralizante de la alusión anterior al dios Momo. (645)

Por su parte Mañero (763) acepta con dudas la nota de Torres: "tal vez se mencione irónicamente a don Alonso el Casto como prototipo de castidad".

Pero nada tiene que ver aquí don Alonso el Casto. Volvamos al pasaje de Justina, donde se reúnen dos menciones, la segunda provocada por la pri- 
mera. $\mathrm{Al}$ averiguar con la charla de la mesonera todos sus secretos comenta la inutilidad de la ventana o vidriera que el dios Momo quería haber colocado en el pecho del hombre, pues sin ese recurso ha averiguado todo lo que quería. El mismo deseo del dios Momo se atribuyó en algunos textos al rey don Alfonso X el Sabio, que es el don Alonso citado por Justina. Basten algunas pocas líneas de Noydens en su Historia moral del dios Momo:

decía [Momo] que el corazón del hombre es inescrutable y no hay quien pueda apear sus pensamientos, ni calar sus retretes y cuando más de cava en sus paredes se descubren mayores abominaciones. Pase aquí la censura de Momo por cierta y verdadera, pues el rey don Alonso el Sabio también dijo que la naturaleza había errado en la fábrica de los hombres, porque se les había de hacer una ventana en el pecho por donde se vieran los secretos del corazón...

El motivo de la ventanilla de Momo proviene seguramente del Hermotimus de Luciano, y de una fábula de Esopo, y se extiende por numerosos textos del Siglo de Oro, con éxito impulsado también por el Momus sive de principe de Leon Battista Alberti, traducido al español por Agustín de Almazán en 1553, de quien toma Noydens el pasaje citado?.

La pretensión de Alfonso X de ser capaz de mejorar la obra de la naturaleza (es decir, la de Dios) le ganó la fama de soberbio, y pasó a las historias y relatos de varia índole. Añadiré solo el de la Historia de la insigne ciudad de Segovia y compendio de las historias de Castilla de Diego de Colmenares, cap. 22:

Murmurábase que el rey se había dejado decir en secreto y en público, que si asistiera a la creación del mundo, algunas cosas se hicieran diferentes (gracejo parece del Momo de los gentiles). Nuestras historias escriben, que en Burgos Pedro Martínez de Pampliega, ayo del infante don Manuel su hermano, por divina revelación, le había avisado aplacarse con penitencia a Dios, que ofendido de tan grande impiedad, le amenazaba con pérdida de reino y vida; y que despreciando la amonestación había porfiado en el desatino.

Estando, pues, en nuestra ciudad, quiso Dios, detenido siempre en el castigo, reducirle con nuevos avisos. Llegó al alcázar, donde el rey se hospedaba, un religioso franciscano, varón de la santa vida: algunos dicen que era fray Antonio nombrado de Segovia, por natural de nuestra ciudad, de cuya santidad escriben

9 Ver Egido 2000. El motivo está en Erasmo, Gracián, Alemán, Salas Barbadillo, etc. En algunos casos, como el de La pícara Justina se atribuye también a Alfonso el sabio. Noydens recoge en el texto que cito a Alberti, en la traducción de Agustín de Almazán. Ver Coroleu 1994. En los preliminares de La pícara Justina se menciona el Momo de Alberti. 
las historias franciscanas y escribiremos en nuestros claros varones. Este pues con modestia religiosa habló al rey en esta sustancia:

No hubiera, señor, venido de mis claustros a vuestros reales pies con menos impulso y motivo que de Dios, a quien tenéis ofendido con presunciones inconsideradas: pues habiéndoos criado aventajado en bienes temporales de tantos reinos, y espirituales de tan alto entendimiento, usando mal de tantos favores, os rebeláis contra vuestro criador, presumiendo que sus obras pudieran ser más perfectas con vuestra asistencia. No imitéis al más bello de los ángeles, hoy por su soberbia el peor de los demonios. Emendad en vos mismo, pues ahora podéis, y os importa tanto, lo que presumiades emendar en la fábrica del mundo perfectísima obra, en fin, de la perfección divina. Reconoced culpa tan sacrílega y con penitencia inclinad la misericordia de Dios al perdón; y no irritéis su inmenso poder al castigo: pues sabéis que no es este el aviso primero y podría ser el último.

El rey se alteró demasiado y respondió airado: y el religioso, cumplida su embajada, aunque no su deseo, volvió a su convento. Aquella misma noche cargó sobre el alcázar tan terrible tempestad de agua, truenos y relámpagos tan pavorosos, que el más animoso vía la muerte. Un rayo en la misma pieza en que los reyes estaban rajó las techumbres, que son bóvedas de fortísima cantería; y abrasando el tocado a la reina, consumió otras cosas de la cuadra. No alcanzaba el rey esta tempestad con su astrología y saber, porque la causaba su ignorancia. Despavoridos ambos, salieron voceando. El rey instaba le trajesen aquel religioso. Venció el temor a la obediencia y ninguno se atrevía al peligro. En fin uno de la guardia en un buen caballo llegó a San Francisco y trajo al religioso instado de su guardián. La tempestad y pavor crecían, hasta que comenzando el rey a confesar la culpa, con el arrepentimiento menguaba la tempestad milagrosamente; y al siguiente día abjuró en público la blasfemia.

\section{Los incombustibles: larins, setin, arbeston, vela de Venus, mantel de Plinio, dedo de Pirros y cuerpo de falisco}

Una serie de menciones dignas de comentario se acumulan en el lib. IV, cap. 4, como ejemplos de materias o seres resistentes al fuego:

Era fuego y quememe, que ni soy Larins, ni Setin, ni Arbeston, ni pabilo de la vela de Venus, ni mantel de Plinio, ni dedo de Pirros, ni cuerpo de Falisco para que el fuego no me queme. (Mañero: 946; Torres: 846). 
Damiani (452) anota:

Laris, setín, arbestón: laris=larix, lárice o alerce, cuya madera reputada incombustible fue antiguamente muy empleada en el mediodía de España; setín era el nombre de una especie de madera entre los hebreos, por lo visto, también incombustible; asbestón: asbesto.

Pabilo de la vela de Venus: no he podido encontrar ninguna referencia a este "pabilo".

Mantel de Plinio: alusión al hecho de que el cuerpo de Plinio el Viejo [...] fue descubierto en condición perfecta y completamente vestido después de que el famoso escritor muriera en la erupción del Vesubio en el año 79. Su sobrino, Plinio el Joven, relata este episodio en sus Epístolas, libro VI, carta 16.

Dedo de Pirros: dícese que el dedo gordo del pie derecho de Pirros (filósofo griego del siglo IV a. de J. C.) tenía una propiedad divina, así que después de que su cuerpo fuera consumido por las llamas se observó que dicho dedo quedó ileso por el fuego, según comenta Plutarco [... ] en su Las vidas paralelas, cap. III.

Falisco: puede identificarse, quizá, con el antiguo dios del Fuego, entre los romanos, Falacer.

\section{Torres aduce las notas siguientes:}

ni soy Larins, ni Setín ni Arbestón: serie de anagramas fantasiosos. Cfr. "atribuye ahora nombres de personas -por eso lo escribe en mayúscula la primera edición- a objetos incombustibles. Así Larins es el lárice o alerce, madera que no se quema. Tampoco arde la leña del Setin, hebreo setim. El Arbestón o arbesto es un "mineral de color gris o blanco amarillento, bastante parecido al amianto, pero de fibras duras y rígidas [... también de difícil combustión” (Rey Hazas $[\ldots] "$

ni pábilo de la vela de Venus: nueva confusión, esta vez entre Venus y Diana, porque cuentan Pausanias y Plutarco que en algunos templos de Diana y Júpiter Amnon había lámparas que alumbraban durante años sin consumir aceite $[\ldots]$ mantel de Plinio: protegió su cuerpo cuando la erupción del Vesubio [... ni dedo de Pirros: alusión al dedo gordo del pie derecho de Pirros (filósofo griego del siglo IV a. de Cristo) que a pesar de ser quemado su cuerpo quedó ileso por el fuego (Plutarco, en el capítulo III de sus Vidas paralelas, en Damiani [... ] ni cuerpo de Falisco: quizás Falisco remita a Falacer, antiguo dios del fuego entre los primitivos romanos, según Varrón (Damiani, p. 452, nota 1176). Fue un dios de origen desconocido de cuyo culto se encargaba un sacerdote particular... 


\section{Y Mañero Lozano:}

larins, ni setin, si arbeston: según documenta P. A. [Puyol y Alonso] se alude respectivamente a dos tipos de madera y a un mineral a los que se atribuye la propiedad de ser incombustibles.

pabilo de la vela de Venus: Torres, n. 154, señala una posible confusión con las lámparas empleadas en el templo de Diana, a las que se atribuía la cualidad de arder sin ningún consumo.

dedo de Pirros: Damiani, pág. 452, remite a Plutarco, Vidas paralelas, III [... ]

Falisco: Damiani, pág. 452, sugiere una asociación con el dios romano del fuego Falacer.

Me parecen mejor las minúsculas de Mañero en larins, setin, arbeston, que las mayúsculas de Torres, y mejor aún poniendo minúscula en falisco. Sea como fuere, en ambos casos conviene precisar algunos detalles relativos a estas menciones de Justina.

Larins y setin se refieren, efectivamente a dos clases de madera. La primera es el pino lárice, que según ciertas creencias no se quemaba:

El pino lárice, el cual es una especie de pino, aunque él es uno de los árboles que no se ha de dejar de poner en el número de los excelentes árboles que ser pueda para los edificios, y para sustentar grandísimos pesos encima de sí, y resiste al peso. Hay d'esta madera, en diversos lugares, edificios. A esta madera, que se conserva mucho tiempo, puédesele confiar todo peso, que tiene muy grande bondad. [... E Es muy firme contra toda adversidad. No es dañada esta madera de la pulilla. Hay opinión, y muy antigua, que resiste al fuego y que queda casi sin ninguna lesión. Por donde se pretende que [donde] puede suceder algún daño de cosa de fuego, se debe poner tablas de lárice para remediar ese daño. Cierto, que le he visto quemar, mas al fin, como una cosa muerta, hace su flama muy triste. ${ }^{10}$

Para setin -la madera en la que fue construida el Arca de la Alianza y el tabernáculo- sería suficiente acopiar algunas noticias del volumen Paralipomena quibus ligna sitim explicata et applicata ${ }^{11}$, donde se relaciona también con el lárice, en tanto maderas incombustibles ("quod flammam non concipiat, et aegre comburatur") ${ }^{12}$.

10 Los veintiún libros de los ingenios y máquinas de Juanelo Turriano, fol. $241 \mathrm{r}$.

11 Sontagio y Adamo, Paralipomena quibus ligna sitim explicata et applicata, p. 11.

12 Sobre la madera sitim, y las diversas opiniones acerca de su identificación con variedades de cedro, acacia, espino blanco, etc., ver Henrici Ursini, Arboretum biblicum, cap. XXII. 
El arbeston es sin duda el asbesto o amianto y a lo mismo se refiere el "mantel de Plinio", que no es el vestido que llevaba cuando murió asfixiado por ir a investigar una erupción del Vesubio, sino el lino asbestino, material que comenta en la Historia natural, 19, cap. 1; o 37, cap. 10 (en este lugar solo dice que nace en los montes de Arcadia) ${ }^{13}$ :

Y se ha hallado lino a quien no consume el fuego que llaman vivo, y yo he visto manteles hechos dello ardiendo en el fuego de los convites resplandecer y quedar limpios, quemadas las suciedades, más con el fuego que pudieran lavados en agua $[\ldots]$ llámanle los griegos asbestino o de naturaleza que no se puede quemar $(19,1)$

José Vicente del Olmo, en su Nueva descripción del orbe de la Tierra parafrasea de cerca de Plinio:

Del lino asbestino escribe lo mismo Plinio que del amianto, lib. 19, cap 1, que dél se tejen manteles y varias telas que sucias y machadas le limpian y purifican a la lumbre $[\ldots]$ Del asbesto, piedra que nace en los Montes de Arcadia escriben que una vez encendida no se apaga, otros dicen que no puede apagarse, o que con dificultad se apaga hasta acabar de consumirse. Della escriben Plinio, lib. 37, cap. 10; Solino, cap. 12; San Isidoro, lib. 16, cap. 4... (568)

El anónimo autor de los Veintiún libros de ingenios y máquinas de Juanelo Turriano identifica al amianto con el asbesto:

una piedra llamada amianto, o asbesto, o bostrichite, o polia, o corsoide, o lino carristio, o lino gufelino, o esparto palia. Esta piedra tiene esta propriedad que, molida y puesta con materia que se apegue encima de la madera, la conserva, que no se queme, aunque esté en el fuego. (CORDE)

Y Covarrubias en su Tesoro, sigue también a Plinio, añadiendo alguna anécdota personal:

+Asbesto. Es un género de piedra de color de hierro o plomo que nace en los montes de Arcadia. Tiene propiedad de arder en el fuego sin consumirse ni apagarse, como lo insinúa su nombre [... ] inextinguibilis. Lino asbestino, esta es una tela que algunos dicen hilarse y tejerse de la misma piedra, porque se divide en hilos o briznas muy delgadas. Y a mí me enseñó un extranjero gran pedazo de esta piedra que era en la forma que tengo dicho. Como quiera que sea, es

13 Otra referencia al mantel de Plinio en Pícara Justina, p. 926 ed. Mañero: «esa sábana no se cortó de la tela del mantel de Plinio, el cual se lavaba y purificaba con el fuego». 
cierto que se hacían servilletas de esta tela, y para limpiarlas solo era necesario echarlas en el fuego y que allí ardiesen y se apurasen [... ]. Verás a Plinio, lib. 19, cap. 1, et verbo Ceniza in Additionibus a Luis Vives en los Scholios sobre La ciudad de Dios de San Augustín, libro 21, capítulo sexto. A fray Jerónimo Román en la República genílica, lib. 3, cap. 16.

El pabilo de la vela de Venus es una adaptación algo chistosa y doméstica del motivo de las lámparas inextinguibles, que no se asocian solo a Diana y Júpiter, sino a muchos dioses, santos, templos y altares a lo largo de la mitología y la hagiografía. El P. Juan de Pineda en sus Diálogos familiares de la agricultura cristiana dedica a este tema el cap. 25 del diálogo V, donde menciona numerosas lámparas semejantes, aunque no la de Venus. Sin embargo, entre las autoridades que tienen por posibles estos objetos menciona a San Agustín, De civitate Dei, lib. 21, cap. $6^{14}$, donde en efecto, escribe el santo:

Acaso dirán aquí que por ningún motivo hay semejantes maravillas y que no las creen; que es falso lo que de ellas se dice, falso lo que se escribe, y añadirán, arguyendo así: $\mathrm{Si}$ es que debemos prestar asenso a tales portentos, creed también vosotros lo que asimismo se refiere y escribe que hubo o hay un templo dedicado a Venus y en él un candelero en el cual había una luz encendida expuesta al sereno de la noche, que ardía de manera que no podía apagarla ni la ventisca ni el agua que cayese del cielo; por cuyo motivo, como la citada piedra, se llamó también esta candela lychnos asbestos, esto es, candela inextinguible.

Dirán esto para reducirnos al estrecho apuro de que no podamos responderles [... Respecto al templo de Venus y a la candela inextinguible, no solo con este ejemplo no nos estrechan, sino que nos abren un camino muy anchuroso, puesto que a esta candela que nunca se apaga añadimos nosotros muchos milagros o maravillas de las ciencias así humanas como de las mágicas, esto es, las que hacen los hombres por arte e influencia del demonio y las que ejecutan los demonios por sí mismos, lo cuales, cuando intentáramos negarlas iríamos contra la misma verdad de la sagradas letras, a quien creemos sinceramente. Así, pues, en aquella candela o el ingenio y sagacidad humana fabricó algún artificio con la piedra asbesto, o era por arte mágica lo que los hombres admiraban en aquel templo, o algún demonio bajo el nombre de Venus asistía allí presente con tanta eficacia, que pareciese real y efectivo a los hombres este milagro y permaneciese por mucho tiempo.

También era motivo conocido el del dedo de Pirro, que no era ningún filósofo, sino el rey de los molosos, hijo de Eacidas y Ftia, y de la estirpe de

14 Esta es probablemente la fuente de La pícara Justina. 
Aquiles. Plutarco menciona la calidad maravillosa del dedo en la correspondiente vida de Pirro, Vidas paralelas:

Dícese asimismo que el dedo grueso del pie tenía igualmente una virtud divina, de manera que, quemado el cuerpo después de su muerte, el dedo se encontró ileso e intacto del fuego. (Plutarco, Pirro, 3)

Plinio $(7,2)$ precisa que era el dedo pulgar del pie derecho, cuyo toque curaba a los enfermos del bazo:

En el cuerpo de algunos nacen partes admirables para algo, como al rey Pirro el dedo pulgar del pie derecho, con cuyo toque curaba a los enfermos del bazo. Y escriben no haberse podido quemar con lo demás del cuerpo y que se guardó en una caja entero en el templo.

La fuente inmediata de La pícara Justina debe de ser este pasaje de Plinio, 7, 2, pues justo antes de comentar el dedo de Pirro ofrece la clave del cuerpo de falisco, que no se relaciona con el dios del fuego Falacer, sino con la propiedad atribuida a ciertas familias de los faliscos, llamadas hirpias, de no quemarse en el fuego:

No muy lejos de Roma, en el campo de los Faliscos, hay ciertas familia llamadas hirpias, las cuales en los sacrificios que hacen cada año en el monte Soractes a Apolo, andando sobre hogueras no se queman... (Plinio, 7, 2)

Muchos otros pasajes de este libro plantean todavía preguntas al editor $\mathrm{y}$ al lector. Seguramente el juego bufonesco altera fuentes, adapta motivos y caricaturiza grotescamente los componentes eruditos filtrados por un impulso lúdico que apela al ingenio del receptor. Pero ese ingenio difícilmente puede descifrar las agudezas conceptistas del texto si no dispone de las claves eruditas o de cultura popular del Siglo de Oro que proliferan a cada página. A ese objetivo pretenden contribuir las notas precedentes.

\section{Bibliografía}

ACUÑA, Constanza (2008). "Juan Espinoza Medrano y el motivo de San Cristóbal en la serie de pinturas del Corpus Christi en Cuzco", in Atas do IV Congresso Internacional do Barroco Íbero-Americano. Minas Gerais: UFMG/UFOP/Universidad Pablo de Olavide, 390-405, <http://www.upo.es/depa/webdhuma/areas/arte/4cb/pdf/Constanza\%20 Acu\%C3\%B1a.pdf $>$, consultado en 2015.08.08 
ALBERTI, Leon Battista (1784). El tratado de la pintura por Leonardo de Vinci y los tres libros que sobre el mismo arte escribió Leon Bautista Alberti. Madrid: Imprenta Real.

AUT, Diccionario de Autoridades-Real Academia Española (1990). Madrid: Gredos, 3 vols.

BUTRÓN, Juan de (1626). Discursos apologéticos en que se defiende la ingenuidad del arte de la pintura. Madrid: Luis Sánchez.

CALDERÓN DE LA BARCA, Pedro (2014). Céfalo y Pocris, ed. Ignacio Arellano y Enrica Cancelliere. New York: IDEA. Disponible en: <http://hdl.handle.net/10171/35859>, consultado en 2015.08.08.

CALDERÓN DE LA BARCA, Pedro (1982). El dragoncillo, in Entremeses, jácaras y mojigangas, ed. Evangelina Rodríguez y Antonio Tordera. Madrid: Castalia.

COLMENARES, Diego de (1982). Historia de la insigne ciudad de Segovia y compendio de las historias de Castilla. Segovia: Academia de Historia y Arte de San Quirce, <http://www. cervantesvirtual.com/obra/historia-de-la-insigne-ciudad-de-segovia-y-compendio-de-las-historias-de-castilla--0/>, consultado en 2015.08.08.

CONTI, Natale (2006). Mitología, ed. Rosa María Iglesias y María Consuelo Álvarez. Murcia: Universidad de Murcia.

COROLEU, Alejandro (1994). “El Momo de Leon Battista Alberti. Una contribución al estudio de la fortuna de Luciano en España”, Cuadernos de Filología Clásica. Estudios Latinos, 7, 177-183.

CORREAS, Gonzalo (2000). Vocabulario de refranes y frases proverbiales, ed. digital de Rafael Zafra. Pamplona; Kassel: Universidad de Navarra; Reichenberger. Cuando se cita por esta edición se indica el número del refrán.

COVARRUBIAS, Sebastián de (2006). Tesoro de la lengua castellana o española, ed. Ignacio Arellano y Rafael Zafra. Madrid; Frankfurt: Iberoamericana; Vervuert; Real Academia Española.

EGIDO, Aurora (2000). "La historia de Momo y la ventana en el pecho", in Las caras de la prudencia en Baltasar Gracián, Madrid: Castalia, 49-90.

FERNÁNDEZ GRACIA, Ricardo. Fiesta e imágenes en torno a San Antón, <http://www.unav. edu/web/facultad-de-derecho/detalle-opinionprofesores2/2014/01/19/fiesta-e-imagenes-en-torno-a-san-anton?articleId=3699045 >, consultado en 2015.08.08.

GARCÍA, Francisco (1683). Vida y milagros de San Francisco Javier. Barcelona: Antonio Ferrer.

GARCILASO DE LA VEGA, el Inca (1988). La Florida, ed. Carmen de Mora. Madrid: Alianza.

HENKEL, Arthur y Schöne, Albrecht (1976). Emblemata. Stuttgart: Metzler.

LÓPEZ DE ÚBEDA, Francisco (1977). La pícara Justina, ed. Antonio Rey Hazas. Madrid: Editora Nacional, 2 vols.

LÓPEZ DE ÚBEDA, Francisco (1982). La pícara Justina, ed. Bruno Mario Damiani. Potomac; Maryland: Studia Humanitatis.

LÓPEZ DE ÚBEDA, Francisco (2010). La pícara Justina, ed. Luc Torres. Madrid: Castalia. 
LÓPEZ DE ÚBEDA, Francisco (2012). Libro de entretenimiento de la pícara Justina, ed. David Mañero Lozano. Madrid: Cátedra.

Los veintiún libros de los ingenios y máquinas de Juanelo Turriano, anónimo (2003). ed. Mariano Quirós García. Salamanca: Universidad de Salamanca.

MALAXECHEVERRÍA, Ignacio (1986). Bestiario medieval. Madrid: Siruela.

NOYDENS, Benito Remigio (1666). Historia moral del dios Momo. Madrid: Francisco Nieto.

OLMO, José Vicente del (1681). Nueva descripción del orbe de la Tierra. Valencia: Joan Lorenzo Cabrera.

OSORIO BARBA, Lorenzo (1589). Piña de rosas atadas por graves y santos autores. Salamanca: Guillelmo Foquel.

PLINIO (1999). Historia natural, trad. Francisco Hernández y Jerónimo de Huerta. Madrid: Visor.

RIPA, Cesare (1987). Iconología. Madrid: Akal, 2 vols.

RODRÍGUEZ MARÍN, Francisco (1922). Dos mil quinientas voces castizas y bien autorizadas que piden lugar en nuestro léxico. Madrid: Tipografía de la Revista de Archivos, Bibliotecas y Museos.

SOLÍS Y VALENZUELA, Pedro (1977-1985). El desierto prodigioso y prodigio del desierto, ed, Rubén Páez. Bogotá: Instituto Caro y Cuervo.

SONTAGIO, Cristoforo y Adamo, Johanne. Paralipomena quibus ligna sitim explicata et applicata. Altdorf [Altorfii Noricorum]: Acad, Typogr., s. a., <http://books.google.es/ books?id=eUZGAAAAcAAJ\&printsec $=$ frontcover\&dq=sittim\&hl=es\&sa $=X \& e i=f-$ fOCVLzWFcL5UNechMgB\&ved=0CD0Q6AEwBQ\#v=onepage\&q=sittim\&f=false>, consultado en 2015.08.08.

SOTO, Myrna (2005). El arte maestra. México: UNAM.

URSINI, Henrici (1685). Arboretum biblicum. Norimbergae: Johannis Danielis Tauberi, <http://books.google.es/books?id=UQxcAAAAQAAJ\&pg=PA314\&dq=sittim+laricem\&hl=es\&sa $=X \&$ ei $=$ C_WCVLmZLIKyabSDgpAP\&ved $=0 C C w Q 6 A E w A Q \# v=0-$ nepage $\& \mathrm{q}=$ sittim\%20laricem $\& \mathrm{f}=$ false $>$, consultado en 2015.08.08. 


\title{
D. Sebastião e Alcácer Quibir em duas comédias espanholas do Siglo de Oro: La Tragedia del Rey Don Sebastián y del Príncipe de Marruecos, de Lope de Vega, e Comedia Famosa del Rey Don Sebastián, de Luis Vélez de Guevara
}

Sebastian of Portugal and the battle of Ksar el Kebir in two comedies of the Spanish Golden Age: La Tragedia del Rey Don Sebastián y del Príncipe de Marruecos, from Lope de Vega, and Comedia Famosa del Rey Don Sebastián, from Luis Vélez de Guevara

\author{
António Apolinário LoUREnÇO \\ Universidade de Coimbra - FLUC/CLP \\ ant.apolinario@gmail.com
}

Texto recebido em / Text submitted on: 1.09.2015

Texto aprovado em / Text approved on: 12.10.2015

Resumo: A história peninsular foi, como se sabe, uma das fontes temáticas fundamentais do teatro espanhol do Século de Ouro. Entre os múltiplos textos, mais ou menos contemporâneos dos acontecimentos, que se ocuparam da trágica batalha de Alcácer Quibir, analisamos aqui duas comedias, que, sob uma aparente neutralidade artística, não deixam de ser instrumentos ideológicos ao serviço dos interesses dinásticos da Casa de Habsburgo.

Palavras-chave: Século de Ouro, Comédia, Alcácer Quibir, D. Sebastião

Abstract: The history of the Iberian Peninsula was one of the most fundamental sources for Spanish theatre during the Golden Age. Among several texts, more or less contemporary with the events of the battle of El-Ksar el Kebir, we will analyse two comedies which, despite their apparent neutrality, are ideological instruments at the service of the House of Habsburg.

Keywords: Spanish Golden Age, Comedy, El-Ksar el Kebir, Sebastian of Portugal

1. São abundantes, como se sabe, os temas e os motivos portugueses no teatro espanhol do Siglo de Oro. A noção de espanhol como algo contrastante com o português ainda não existia na época nos territórios que compõem o atual Estado Espanhol, e só incipientemente em Portugal começava 
a fazer-se essa distinção, que também não existe, como bem sabemos, nos camonianos Lusíadas. A Espanha era ainda geralmente entendida como contemplando toda a Península Ibérica ${ }^{1}$, não surpreendendo, por isso, que Luís de Camões apresente o fundador da nacionalidade portuguesa como um soberano espanhol:

Um Rei, por nome Afonso, foi na Espanha,

Que fez aos Sarracenos tanta guerra,

Que, por armas sanguinas, força e manha,

A muitos fez perder a vida e a terra.

(Canto III, 23)

Na descrição da Espanha feita por Vasco da Gama ao rei de Melinde, são inclusivamente identificadas as "nações" que compunham o mapa peninsular e que eram naturalmente aquelas que haviam sido geradas pelo processo medieval da reconquista cristã. Havia entre elas uma salutar competição, porque cada uma queria superiorizar-se às demais como exemplo de garbo e valentia. Assim, nas palavras que Camões atribui a Gama, esta nobre e belicosa Espanha, cabeça da Europa e da cristandade,

Com nações diferentes se engrandece,

Cercadas com as ondas do Oceano;

Todas de tal nobreza e tal valor

Que qualquer delas cuida que é milhor.

(Canto III, 18)

Há ainda que ter em conta que o apogeu da comedia espanhola, representado por autores como Lope de Vega, Calderón de la Barca ou Tirso de Molina, coincide largamente com a época da monarquia dual (1580-1640).

Lope de Vega, o criador do modelo da comédia nova e ao lado de Calderón o seu maior génio, foi, sem dúvida, um dos autores que maior importância atribuiu no seu teatro a figuras e situações portuguesas. O tema foi estudado, em 1936, por Hipólito Raposo, que identificou na obra do comediógrafo espanhol catorze ou quinze obras dramáticas dedicadas a "figuras e factos portugueses, sem contar com outras obras onde há alusões laudatórias ou irónicas à nossa gente, como no Laurel de Apolo em que nomeia

1 Só muito ocasionalmente era usado o adjetivo ibero como sinónimo de espanhol. Uma dessas raras ocorrências acontece na Silva III de El laurel de Apolo, de Lope de Vega: "Tendida en las riberas / del mar de España dulcemente yace / la célebre Lisboa, / de las tierras iberas / la más ilustre y de más alta loa" (apud Viqueira 1950: 187). 
os nossos engenhos poéticos, na Descripción de la Tapada de Vila Viçosa, na Dorotea, comédia em prosa, com repetidas referências a Camões, a outros poetas e suas musas, onde se diz que a língua portuguesa es dulcísima y para los versos más suave" (Raposo 1936: 52). Por sua vez, o antigo professor de Coimbra José María Viqueira contabilizava, em 1950, na obra de Lope de "más de una veintena de asuntos y personajes lusitanos" (Viqueira 1950: 157), sublinhando a existência de uma dupla vertente na relação do "Fénix de los ingenios" com Portugal: "la atracción por el fenómeno portugués, y la conversión del mismo en motivo de arte por gracia y genialidad de su ser" (Viqueira 1950: 157).

É diferente o caso do dramaturgo andaluz Luis Vélez de Guevara, com uma produção dramática consideravelmente menor e cuja obra mais destacada é a novela satírica El diablo cojuelo. Ainda assim, Vélez de Guevara dedicou duas das suas peças mais significativas a dois dos episódios mais mitificados da história de Portugal - a batalha de Alcácer Quibir e a paixão trágica do infante D. Pedro e Inês de Castro -, o que lhe permitiu explorar dois dos tópicos mais correntes sobre o carácter do português, que percorrem grande parte da produção dramática do Século de Ouro, seja de forma séria, como é o caso, seja em registo satírico: se D. Sebastião simboliza a bravura e a tradicional arrogância dos fidalgos lusos; D. Pedro representa a exacerbada paixão portuguesa, tantas vezes elogiada e outras tantas ridicularizada na comédia áurea espanhola ${ }^{2}$. Assim define Brito a paixão de Pedro por Inês em Reinar después de morir: “iQue amor tan de Portugal!”. Ao que este responde: “iQué beldad tan de Castilla!” (Vélez de Guevara 1964: 67)³.

2 No Vocabulario de refranes y frases proverbiales, publicado por Gonzalo Correas em 1627, pode encontrar-se a seguinte entrada: "Derretirse como portugués. Derretido como portugués. Para decir que uno se enamora mucho a cualquiera ocasión, porque esta opinión se tiene de los portugueses, que son muy enamorados y derretidos de puro amor; y por eso los llaman 'sebosos', a semejanza del sebo que se derrite al fuego, con vaya, por ser asqueroso más que cera” (2000: 909). Num texto satírico do poeta barroco espanhol Francisco de Quevedo, El sueño de la muerte, em que se retratam vários tipos de mortes (muerte de frío, muerte de hambre, muerte de miedo, muerte de risa), a muerte de amores está acompanhada por "Píramo y Tisbe, embalsados", "Leandro y Hero y (...) Macías, en cecina, y algunos portugueses derretidos" (Quevedo 1973: 200).

3 Sendo geralmente considerada a melhor obra dramática do autor, Reinar después de morir, que se apresenta como tragédia, não segue o modelo da comédia nova lopesca. Dos muitos exemplos que se poderiam dar da reputação de extremosos apaixonados de que gozavam os portugueses na Espanha do Século de Ouro, fiquemo-nos por uma passagem de La mayor virtud de un rey, de Lope de Vega. Apaixonado por uma dama castelhana chamada Sol, um fidalgo português dirige-lhe o seguinte galanteio: "Hasta ver vuestra belleza / ni amé, ni amaré después". Resposta de dona Sol: "Andá; que sois português / y amáis por naturaleza” (Vega 1925: 81). 
2. No contexto europeu de finais do século XVI, caracterizado pela emergência do Império Otomano como grande potência militar, mas também duramente marcado pelos confrontos bélicos de natureza religiosa (cristãos contra muçulmanos; católicos contra protestantes), não é possível entender a batalha de Alcácer Quibir como um mero conflito dinástico marroquino em que interveio desastradamente um monarca cristão. Travada sete anos antes, em outubro de 1571, a batalha naval de Lepanto, que opôs a armada turca a um contingente naval constituído por navios pertencentes a alguns dos principais estados mediterrânicos cristãos, sob o comando de D. Juan de Áustria, estancara provisoriamente a rápida expansão marítima de um império que, no continente europeu, tinha chegado já às portas de Viena. Mas o perigo islâmico mantinha-se ameaçador.

D. Sebastião era, como se sabe, o único filho do casamento do príncipe D. João, filho do rei D. João III, e de Joana de Áustria, filha de Carlos V e da imperatriz Isabel, irmã do monarca português. Nasceu D. Sebastião em 20 de janeiro de 1554, menos de três semanas depois da morte de seu pai, que era naquele momento o único sobrevivente dos nove filhos legítimos de D. João III. Ficava momentaneamente assegurada a sucessão do reino de Portugal, evitando-se o risco imediato da sua diluição no conjunto dos reinos peninsulares ${ }^{4}$. Educado por um sacerdote jesuíta, Luís Gonçalves da Câmara, e na ausência da mãe, que voltou para Espanha quando o filho ainda não completara os quatro meses de idade, o futuro rei juntaria a um extremado fervor religioso a obsessão por deixar associado o seu nome, nas crónicas régias, a um glorioso feito militar, o que contratava com a prudência da política africana do seu avô D. João III, que, por motivos militares e económicos, perdera ou abandonara as praças norte-africanas de Agadir, Safim, Azamor, Alcácer Ceguer e Arzila ${ }^{5}$. António Quadros entende que não é justo respon-

4 Como explica Antonio Domínguez Ortiz, a união política entre Castela e Aragão efetuada pelos Reis Católicos "fue mucho menos sólida de lo que suele pensarse", não tendo eliminado nenhuma das instituições próprias de qualquer dos reinos (Domínguez Ortiz 1973: 37). Apesar de o futuro rei Filipe II ser comummente identificado como "príncipe das Espanhas” (Bouza 2011: 30), o “Testamento del Emperador Carlos V”, datado de 1554, deixa transparecer a ausência de uma estrutura político-administrativa unitária nos territórios herdados pelo seu filho Filipe, assim identificados: "la corona de Castilla y Aragón, Nápoles, Sicilia”, (... ) nuestros Estados y senhorios de Borboña, Brabante, Flandres y (...) todos los demás de las tierras bajas a nos pertencientes” (apud Prudencio de Sandoval 1956: 539).

5 Supõe Queiroz Veloso que Luís Gonçalves da Câmara, que passara alguns meses em África, deveria lamentar "o abandono das nossas praças", o mesmo ocorrendo com alguns dos oficiais que exerciam a função de sumilheres de D. Sebastião: "Entre os quatro semilheres que semanalmente se revezavam no serviço do rei, havia um, D. Fernando Álvares de Noronha, várias vezes ferido em terras da mourama, cujo pai exercera com distinção o governo de Azamor. Outro que também defenderia a 
sabilizar excessivamente Gonçalves da Câmara pelas ideias expansionistas de D. Sebastião, porque o sentimento de que a nação portuguesa entrara numa decadência que tinha de ser contrariada era comum à generalidade dos portugueses. Apoiando-se n'O Encoberto de Sampaio Bruno, Quadros (cf. 1982: 35-57) cita, a propósito, as Regras para a Educação de El-Rei D. Sebastião, da autoria de Diogo de Teive, que vaticina grandes feitos ao jovem rei, o mesmo fazendo António Ferreira e, sobretudo Camões, que, assinalando D. Sebastião como novo temor da Maura lança (Canto I, 6), explicitamente o incita a cometimentos militares:

Comecem a sentir o peso grosso,

Que polo mundo todo faça espanto,

De exércitos e feitos singulares

De África as terras e do Oriente os mares.

(Canto I, 15)

Questões dinásticas bem mais complicadas assolavam os reinos de Fez e de Marrocos, unificados por Mohamed ech-Cheikh, monarca da dinastia saadiana, que se envolveu em sangrentas batalhas com o irmão mais velho, Ahmed al-Araj. Feito prisioneiro em Marraquexe, Ahmed al-Araj e vários dos seus descendentes foram sumariamente executados pelo governador da cidade após a morte de Mohamed ech-Cheikh, para garantir a sucessão ao filho deste, Abdalah el-Ghalib, que, por sua vez, transmite o poder ao seu filho Abu Abdalah Mohamed II Saadi, ou mais simplesmente Mulei Mohamed.

Tanto Abdalah como Mulei Mohamed continuaram a política da eliminação violenta dos parentes mais próximos para evitarem conspirações e garantirem a transmissão do poder régio aos seus herdeiros diretos. Dois irmãos de Abdalah, Abd el-Malik (Mulei Moluco) e Ahmed al-Mansour (Almançor; Hamet e Hamete nas comédias), foram obrigados a procurar proteção no Império Turco, que nessa altura já se estendia até aos territórios localizados a norte da atual Argélia, incluindo a cidade de Argel.

Em 1576, apoiado por um forte contingente militar turco, Mulei Moluco conquista ao seu sobrinho os reinos de Fez e de Marrocos, levando o monarca derrotado a pedir ajuda ao rei de Portugal para reconquistar o território, que

expansão portuguesa em Marrocos. D. Sebastião foi, portanto, educado num ambiente propício às suas inclinações guerreiras, em que as empresas de D. João I e D. Afonso V eram exaltadas como bons exemplos, o que implicitamente correspondia à condenação da política de renúncia de D. João III (Veloso 1935: 93). 
passaria a constituir uma espécie de protetorado do monarca português. As consequências do pedido são sobejamente conhecidas.

3. A ação dramática das peças de Lope e de Vélez de Guevara aqui estudadas só é tematicamente coincidente numa das suas três jornadas: o conteúdo dramático da primeira jornada da comédia de Lope de Vega é idêntico à terceira do autor da Comedia famosa, pois são aquelas em que se descreve a batalha de Alcácer Quibir e as suas consequências trágicas. Complementarmente, são minuciosamente escrutinados, na comedia de Vélez de Guevara, os antecedentes e os preparativos da trágica batalha, enquanto Lope de Vega dedica as duas últimas jornadas ao destino do príncipe Mulei Xeque, filho do desditoso rei Mulei Mohamed, falecido na batalha tal como D. Sebastião.

La tragedia del rey don Sebastián y bautismo del príncipe de Marruecos foi publicada na Oncena Parte das Comedias de Lope de Vega Carpio, editada em 1618. Menéndez Pelayo considerava, no entanto, que a sua redação remonta ao ano de 1593, no qual ocorreu o batismo cristão do príncipe Mulei Xeque (Menéndez Pelayo 1969: 150) ${ }^{6}$. O erudito santanderino recorda igualmente que na lista de obras de Lope enumeradas en El Peregrino en su patria, de 1603, se encontra uma peça intitulada El príncipe de Marruecos que supõe ser a mesma da Oncena Parte (ibid.), ou pelo menos uma parte dela, pois também aventa a hipótese de Lope ter fundido numa só duas comedias distintas, dada a disparidade estilística e temática entre a primeira jornada e as duas restantes (ibid.: 152). Não tem qualquer valor distintivo a classificação de tragedia usada por Lope e a de comedia utilizada no título da obra de Luis Vélez de Guevara. De acordo com os preceitos expostos pelo próprio Lope em Arte nuevo de hacer comedias en este tiempo não se aplicam ao teatro espanhol do Século de Ouro as regras que regiam a dramaturgia clássica e que permitiam distinguir perfeitamente a tragédia e a comédia. A comedia espanhola é híbrida: os assuntos sérios coabitam com os triviais, grotescos ou

6 Menéndez Pelayo cita, a propósito esta nota coeva de Antonio de León Pinelo, recolhida nos seus Anales de Madrid: "Muley Xeque, Príncipe de Marruecos, hijo de Muley Mahomet, Rey de Fez y Marruecos, habiendo sido echado del reyno por Muley Moluc, su primo, se vino a España, y desengañándose de su falsa seta, recibió el agua del bautismo. Estuvo algún tiempo en el convento de la Victoria, donde le catequizaron. De allí fue llevado con mucho acompañamiento a las Descalzas Reales a recibir el bautismo. Fueron sus padrinos el Príncipe don Felipe y la Infanta doña Isabel. Llamóse don Felipe de África, y comúnmente el Príncipe Negro, porque lo era mucho. El rey le dio hábito de Santiago y encomienda, con que vivió honrado y estimado en la Corte. Murió en la $\mathrm{Fe}$ Católica, sirviendo en Flandes" (apud Menéndez Pelayo 1969: 152). 
burlescos ${ }^{7}$, do mesmo modo que as personagens de elevado gabarito social convivem com a gente comum. Na verdade, embora o assunto seja, neste caso, sério em qualquer das obras, é na de Vélez de Guevara que o desenvolvimento dramático mais se aproxima da tragédia, tanto pela unidade da ação como pela insistência, nas segunda e terceira jornadas, dos agouros que indiciam o final trágico.

Na peça de Lope, a ação abre praticamente com um encontro historicamente inexistente entre D. Sebastião e o deposto rei marroquino Mulei Mohamed. Uma longa fala do rei de Marrocos põe o espetador ao corrente do problema político. É evidente essa função informativa, porque a personagem revela uma estranha neutralidade na descrição da situação, não valorizando, como seria verosímil, a sua perspetiva pessoal. Fica claro que, como denunciam as fontes coevas, um acordo estabelecido pelo seu avô e um tio-avô o coloca como usurpador, pois aqueles seus ascendentes haviam determinado que o direito ao trono transitaria de irmão para irmão, de acordo com a idade, e só depois da morte do último irmão ascenderia ao trono um filho do primogénito. Isto é, ficara consagrado "que sucediese en el reino / cualquier hijo de los dos, / antes que cualquiera nieto." (p. 124)

Não obstante a aversão cristã à religião muçulmana, o estatuto real de Mulei Mohamet confere-lhe um inevitável destaque social, que transparece das falas iniciais do rei português e das principais personalidades da corte, e justifica o lugar de relevo concedido ao deposto rei na sessão que decorre na corte portuguesa. "Al Rey se da asiento igual", são as primeiras palavras pronunciadas por D. Sebastião (p. 123), enquanto Luis de Silva perguntará retoricamente “QQué habrá que el talle no venza?” (p. 123). Terá lugar pouco depois o encontro de D. Sebastião com Filipe II, em Guadalupe. Filipe desaconselha o sobrinho a deslocar-se pessoalmente a África, assumindo diretamente o comando do exército cristão, mas está de acordo com o propósito da expedição. Lope de Vega faz a sua leitura pessoal dos textos das crónicas quando sintetiza o acordo a que chegaram os dois reis peninsulares. Por conselho do duque de Alba ficara estabelecido que o exército cristão deveria contar com quinze mil homens, "tudescos, españoles e italianos" (p. 130), cabendo a Portugal o pagamento de dez mil e a Castela o encargo monetário com os restantes. Como era habitual na época, no conceito de espanhol

"Lo trágico y lo cómico mezclado, / y Terencio con Séneca, $[\ldots]$ / harán grave una parte, otra ridícula; /que aquesta variedad deleita mucho" (Vega 1967: 14-15). 
estão seguramente compreendidos tanto os súbditos de Filipe como os de D. Sebastião ${ }^{8}$.

Como também acontece na comédia El duque de Viseo, em que se põe de manifesto a injustiça da ação de D. João II sem, no entanto, se questionar a legitimidade dos atos régios (porque "Siendo el Rey general, a nadie injuria, p. 135) ${ }^{9}$, Lope de Vega revela o talento necessário para, sem transgredir os códigos sociais a que a comédia obedecia, demonstrar os erros de organização e o excesso de confiança do rei nas suas qualidades guerreiras. Através do diálogo entre dois simples soldados, Rosales e Carpio, que se fazem porta-vozes dos comentários populares, ficamos ao corrente da estrutura básica da expedição militar e dos seus chefes, mas também da escassez de recursos humanos - esperava-se que uma parte do exército marroquino abandonasse Muley Maluco (Mulei Moluco) e se juntasse a Muley Mahamet (Mulei Mohamed) - e das debilidades organizativas:

Quiere experiencia el militar oficio;

aquí todo va gente regalada,

aunque de su valor se muestre indicio;

mas no está en el uso de la espada,

amigo Carpio, el militar gobierno,

sino en la disciplina ejercitada. (p. 134).

São comuns na obra de Lope os elogios à valentia dos portugueses, que o dramaturgo compara com os filhos de Castela, em que ele mesmo se contava. É o que acontece em El Brasil restituido, que põe em cena a oposição das forças conjuntas luso-castelhanas à invasão de Salvador de Bahia pelos holandeses em 1624. Fala a personagem alegórica Brasil:

Aquí las alegres salvas

destas dos fuertes naciones,

que, por nueva unión hermanas,

la emulación de sus glorias

8 Baseando-se nas principais crónicas da batalha, que apresentam números por vezes desencontrados, Queiroz Veloso (1935: 343) estimou o número de combatentes do exército cristão em cerca de 16.500 homens, dos quais 14.600 seriam infantes, 1.300 cavaleiros e cerca de 600 os partidários de Mulei Mohamed.

9 A comédia El duque de Viseo começa com um diálogo entre o duque de Viseu e o Contestável, em que o segundo responde assim ao primeiro, que se queixava da aspereza do rei D. João II na sua relação com os seus súbditos, incluindo aqueles que empreendiam ações de grande mérito (como era o caso do próprio Contestável do reino, que voltava vitorioso do Norte de África): "No hablemos desto yo y vos, / y esta máxima se crea: / que cualquiera que el Rey sea, / al fin representa a Dios" (Vega 1966: 36). 


\begin{abstract}
hace parecer contrarias, fue, con notable alegría, porque fuera Lusitania única, a no haber Castilla, por las letras y las armas, y si Portugal no hubiera, Castilla por Fénix rara se celebrara en el mundo; pero juntándose entrambas, no digo yo mi conquista, pero aquella piedra santa que fue sepulcro de Cristo, fuera victoria de España. (apud Viqueira 1950: 295).
\end{abstract}

Na Tragedia de don Sebastián o apreço de Lope pela valentia dos portugueses manifesta-se, por exemplo, no diálogo entre o rei Moluco e o seu irmão e herdeiro Hamet quando têm conhecimento de que o exército de $\mathrm{D}$. Sebastião dispõe somente de quinze mil efetivos militares. Naquele contexto, a ironia está forçosamente ausente. A comparação da valentia de D. Sebastião com o seu avô Carlos V é uma constante na peça:

\author{
HAMET \\ No trae un hombre más el Lusitano, \\ seno es que del valor los autorices. \\ Trae el bastón en la siniestra mano \\ con tal grandeza en años tan felices, \\ que quien en Túnez vio triunfando a Carlos, \\ quiere en presencia y armas igualarlos. \\ Hace de General el digno oficio, \\ y Maestre de campo es Eduardo \\ de Meneses, gallardo a mi juicio.
}

MALUCO

En siendo portugués, será gallardo [...

(pp. 139-140)

Tenha-se em conta que o teatro de Lope - e esta peça tem bastantes didascálias com o exclusivo propósito de orientar a encenação (o Autor na linguagem da época) - tinha fundamentalmente como destinatário o público que frequentava os "corrales" castelhano-aragoneses. A consciência da exis- 
tência de uma comunidade cultural hispânica é tão genuína no teatro de Lope como nos já referidos Lusíadas camonianos, em que se exaltam os reinos espanhóis, entre os quais se inscrevia, como "cume da cabeça de Europa toda", o reino Lusitano (Canto III, 20).

Há por outro lado, nalguns comportamento do rei e nos discursos laudatórios que lhe dirigem os mais importantes fidalgos de Portugal, a manifestação de uma sobranceria e de uma petulância também recorrentes na caracterização do português no teatro de Lope e de outros importantes dramaturgos do Século de Ouro. A crítica da arrogância é por vezes feita de forma paródica, o que não é o caso, dadas as consequências trágicas da impetuosidade demonstrada pelo jovem monarca português. Enquanto o alferes-mor assegura ao rei a impossibilidade de uma derrota do exército cristão, o prior do Crato sugere que, apesar de toda a sua grandeza, o próprio rei Filipe e o duque de Alba não conseguem ocultar por completo o temor de os seus feitos serem eclipsados pela grande vitória que aguarda $\mathrm{D}$. Sebastião:

\author{
Teme este fuerte español [o duque de Alba], \\ viendo al primer arrebol \\ que te hace el África salva, \\ que ha de obscurecerse el Alba \\ cuando amanezca tu Sol. \\ Filipo, que al Occidente \\ declina, teme también \\ que los rayos de tu Oriente \\ tanta luz a España den \\ como el laurel de tu frente. ( $p$ 136)
}

Embora só a primeira jornada da comédia de Lope seja exclusivamente dedicada à fracassada jornada africana de $\mathrm{D}$. Sebastião, a descrição da batalha a que aí se procede é feita de modo desconexo e fragmentário, realçando-se o heroísmo em combate manifestado pelo jovem rei português, a morte de Mulei Moluco e a consequente substituição pelo irmão, tal como dispunham as normas sucessórias vigentes.

Uma descrição mais global da batalha, sob a forma estrófica do romance, aparece no início da segunda jornada, antecedendo aquela que passa a ser a ação principal: a já mencionada conversão ao cristianismo e o batismo do príncipe de Marrocos, filho do rei vencido, que ficara sob a proteção do monarca ibérico, Filipe (II de Espanha e I de Portugal). Nesta crónica versificada da batalha, narrada muitos anos depois por Albacarín (Cid-Abdelcherim), alcaide mouro de Arzila, a Mulei Xeque, que tinha 
apenas doze anos na época da trágica contenda, volta a destacar-se a coragem dos portugueses, que haviam enfrentado com quinze mil homens um exército de cem mil. D. Sebastião é mencionado como "el cristiano famoso, / más que dichoso arrogante, / a quien no pudo Filipo / desta empresa desvialle" (p. 145) ${ }^{10}$.

4. Quanto à obra de Vélez de Guevara, as fontes fundamentais são um manuscrito que integrava o espólio de Agustín Durán, oferecido à Biblioteca Nacional de Espanha em 1863, e uma edição impressa do primeiro terço do século XVII, descoberta em 1886 pelo hispanista alemão Adolf Schaeffer, sem a capa e sem as folhas iniciais, no qual Del rey don Sebastián. Comedia famosa é a décima peça de um volume de doze (Herzog 1972, 5-8). Sob o título desta comédia figurava a informação de foi representada por Riquelme. É sobretudo nesta versão impressa que se baseia a edição realizada em 1972 por Werner Herzog para a Real Academia Española, chamando-se por isso Comedia famosa del Rey don Sebastián, enquanto a recente edição de William R. Manson e C. George Peale (2014) segue fundamentalmente a lição do manuscrito depositado na Biblioteca Nacional, que é uma cópia feita a várias mãos e não um autógrafo, adotando por esse motivo o título do manuscrito, idêntico ao das crónicas coevas: La jornada del rey don Sebastián en África. Sem que isso corresponda a qualquer juízo de valor sobre uma ou outra opção, citarei o texto a partir da versão impressa.

Como dissemos, a obra de Luis Vélez de Guevara é exclusivamente dedicada à tragédia de Alcácer Quibir. Como é natural, embora os acontecimentos fossem relativamente recentes, os meios de difusão do conhecimento naquela época não eram propriamente eficazes e era necessário dar ao espetador a informação necessária para que este compreendesse o que se passava em cena. Os antecedentes da intervenção de africana de D. Sebastião são expostos logo no início da primeira jornada. Não respeitando a verdade histórica, o dramaturgo apresenta o conflito entre Mulei Moluco e Mulei Mohamed como se se tratasse de uma intriga palaciana: coincidindo com

10 Segundo o anónimo autor de Jornada de África del rey D. Sebastião Escrita por um Homem Africano, Filipe II terá começado por enviar um embaixador ao sobrinho para o dissuadir da sua resolução de intervir no conflito dinástico marroquino, concedendo-lhe depois em Guadalupe um apoio limitado e condicionado. Queiroz Veloso (1935: 266) registou sem tibiezas que "é de justiça pôr em relevo que Felipe II procurou, por todos os meios, demover o sobrinho do seu louco intento". Apesar dos seus esforços para se encontrar com o duque de Alba antes da sua partida para Marrocos, o rei português não conseguiu esse encontro (cf. Jornada de África 2004: 13). Na peça de Lope, D. Sebastião lastima que isso não tenha acontecido quando acolhe as tropas castelhanas comandadas por Francisco de Aldana. 
a chegada da "sultana", noiva de Mulei Moluco, que vem acompanhada pelo vizir de Istambul e escoltada por cinco mil janízaros, Mulei Mohamed é alvo de um golpe de estado que o obriga a fugir e a pedir ajuda aos monarcas cristãos. Apesar de nesta peça Mulei Mohamed, identificado apenas como "xarife", não ser tão claro a reconhecer a sua ilegitimidade (porque não aceita o acordo estabelecido entre o seu avô e o seu tio-avô), também aqui é referido o acordo sucessório já descrito a propósito da comédia de Lope, segundo o qual o poder deveria ter transitado do pai de Mulei Mohamed para o seu irmão Mulei Moluco:
Si mi agüelo pretendió
Que sus hijos sucediesen,
Puesto que naciese yo,
Porque Reyes todos fuesen,
Contra Mahoma pecó;
Que yo soy el heredero,
Pues soy el hijo mayor
De Abdala, que fue primero
De aquestos Reynos señor;
De cólera desespero.
(pág. 66) ${ }^{11}$

É também reconhecido pelo próprio Mulei Mohamed, que disso se lastima, que é Moluco o preferido do povo. Queiroz Veloso (1935: 222) aventa a hipótese de as preferências do povo por Mulei Moluco estarem relacionadas com o facto de Mohamed ser filho de uma escrava negra. Recorde-se a anterior referência (nota 6), ao facto de o filho do rei deposto ser conhecido por "príncipe negro".

11 A regra sucessória é claramente exposta por Antonio de San Román, na sua Jornada y muerte del rey don Sebastián de Portugal, de 1603, que dedica um breve capítulo a explicar o acordo feito por Mulei Mahamet (escrevo o apelido de acordo com a ortografia da obra, mas trata-se de Mohamed ech-Cheikh, já referenciado), a que chamaram Xarife e que foi conquistador dos reinos de Marrocos, Fez e Tarudante, e o seu irmão Mulei Hamet (ou seja, Ahmed al-Araj; a semelhança e repetição dos nomes dos monarcas, que prosseguirá nas gerações seguintes, dificultam claramente o entendimento da história), "quedando concertado entre los dos, cuando estaban en su pujanza, que por cuanto ellos tenían hijos, antes de verse en ella, sucediese después de su muerte al tío menor de edad, el mayor de los sobrinos" (San Román 1603: 14-15). Era, portanto, ilegítima a transmissão do poder feita por Abdalah, filho de Mulei Mahamet, ao seu filho primogénito, quando estavam vivos dois dos seus irmãos. Acolhendo-se sob a proteção do Império Turco e ganhando prestígio pela valentia demonstrada nas lutas contra os cristãos, Mulei Moluco conseguiu que o sultão de Constantinopla lhe fornecesse soldados para fazer guerra ao sobrinho. San Román refere igualmente a grande simpatia de que gozava Mulei Moluco entre os mouros marroquinos (San Román 1603: 18). 
Um segundo momento da comédia é preenchido pela relação entre D. António e o seu escravo mouro Zeylán, figura de elevado estatuto social na sociedade marroquina, que o prior do Crato liberta sem resgate. Este episódio, fictício, terá consequências na fase final da peça, quando, também contrariando a verdade histórica, o antigo escravo do prior do Crato consegue obter do rei marroquino a libertação, igualmente não onerosa, do seu antigo amo.

Há uma evidente ambivalência na forma como é tratado D. Sebastião, que aparece na parte final da jornada. Depreende-se que faltou ao rei (cujas qualidades de cristão e de cavaleiro são notórias, numa aceção ainda medieval) uma educação adequada que o preparasse para as funções reais que desempenha. Despreza as artes, com exceção da esgrima, e menospreza a burocracia do Estado, como o prova o facto de continuar a praticar esgrima enquanto despacha os assuntos de governação que lhe são trazidos pelo seu secretário. A jornada inicial acaba com a chegada do deposto rei marroquino que vem pedir apoio para a sua causa a Sebastião. Este, sublinhando a sua condição de português e espanhol, compromete-se a fazer o possível por dar resposta positiva ao pedido do marroquino. Surgem igualmente nesta jornada os primeiros augúrios de uma possível ameaça divina contra Portugal. Trata-se de um cometa que efetivamente apareceu nos céus portugueses na fase final do reinado de $\mathrm{D}$. Sebastião e, obviamente, assustava as populações. $\mathrm{Na}$ comédia, é o duque de Aveiro (designado na obra por Abero) que dá conta do fenómeno, dirigindo-se ao ao rei de Portugal:

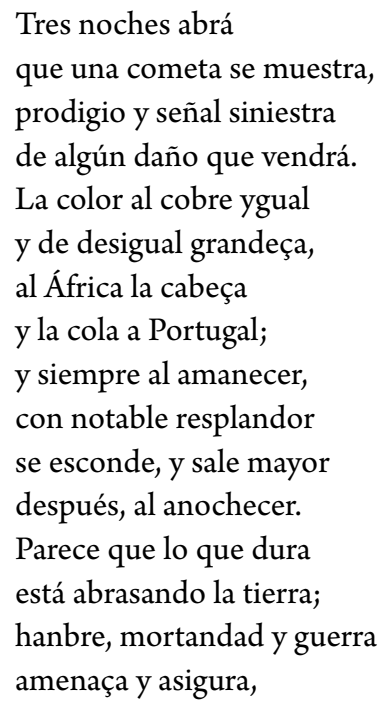


según astrólogos, tanto

que está Lisboa afligida.

(p. 87)

Na segunda jornada, que conhece o seu término no encontro de Guadalupe entre os dois monarcas ibéricos, destaca-se, pelo espaço que ocupa e pela qualidade da informação aí veiculada, o encontro fortuito de D. Sebastião com um guardador de gado (baquero), quando o rei vai caçar sozinho e se perde da comitiva que se dirige ao famoso mosteiro da Extremadura espanhola ${ }^{12}$. O vaqueiro, que não reconhece o rei e funciona também como o efémero gracioso da peça, volta a falar do cometa que amedronta o povo (chama-lhe dragão de três cabeças) e de vários outros maus augúrios que desaconselham a guerra. Julgando ter como interlocutor um fidalgo influente e próximo do rei, acaba por lhe dar alguns conselhos para que este os transmita a D. Sebastião. É difícil não cotejarmos esta cena com o episódio camoniano do velho do Restelo:
Ya que aquese oficio os toca, decilde, por bida vuestra al Rey que es jornada loca esta que en África yntenta, pues los moros no le an echo ningún agrabio, ni afrenta. Goce del dorado lecho de su casa en paz contenta, deje al Maluco, no yntente yr a ocupar con su gente el África, si desea biuir, que no ay quien no sea dentro de su casa baliente. Goce su edad y la silla de Portugal, cásese, pues tantos Reynos humilla, $y$ un heredero nos de en la infanta de Castilla” (p. 105).

\footnotetext{
12 Uma estratégia dramática semelhante ocorre na comédia de Tirso de Molina Las quinas de Portugal, quando Afonso Henriques se perde igualmente durante uma caçada e se encontra com o pastor Brito, que também não o reconhece.
} 
Os maus presságios adensar-se-ão na terceira jornada, que culmina com a morte do jovem monarca português. Começa essa jornada com uma inesperada queda do seu cavalo de D. Sebastião, que era um cavaleiro exímio, e o duque de Aveiro aproveita o ensejo para recordar ao seu rei muitas outras estanhas ocorrências que assolam a terra lusitana e parecem augurar uma tragédia (terramotos; montes que vertem fogo; sangue a correr entre o Tejo e o Mondego; a morte acidental de três marinheiros do esquife do xarife marroquino; a queda do próprio rei ao mar quando ia encontrar-se em Cádiz com o duque de Medina). Sem deixar que os supostos presságios o perturbem, D. Sebastião acolhe com entusiasmo a chegada do capitão Aldana, que era, para além de experiente militar, um brilhante poeta espanhol ${ }^{13}$, enviado pelo duque de Alba e que lhe traz a espada que fora usada por Carlos V na conquista de Tunes ${ }^{14}$. Outro mau augúrio: ao pegar na espada, o rei corta-se na lâmina. Na véspera da batalha, em claro contraste com o difundido mito do aparecimento de Cristo a Afonso Henriques em Ourique, garantindo-lhe a vitória, é a morte, sob forma feminina, que irrompe pelo sonho do rei português aconselhando-o a desistir do confronto para salvar a sua vida e a honra dos seus vassalos. No entanto, D. Sebastião interpreta todos estes agouros como sinais positivos e prenunciadores da sua vitória. Sente-se "benganza (... ) de Rodrigo / y relíquia de Pelayo” (p. 137) e quer dar provas da bravura de "un Rey / español y lusitano" (p. 138). Recusa-se inclusivamente a atrasar a batalha, quando recebe a informação de que Mulei Moluco está moribundo. Em pleno combate, torna-se cada vez mais evidente que a fortuna é adversa aos portugueses, mas D. Sebastião permanece insensível aos avisos e aos perigos, rejeitando a fuga ou a rendição, mesmo perante a evidência da derrota. Quando depara com Mulei Moluco já morto (outra liberdade poética, pois nenhum cronista regista este encontro), já a sua arrogância se entrecruza com a loucura:

Berme a mí biuo temió, y así me esperó difunto, porque no lo hiciese yo.

Corrido estoy de mirar que te quisiste morir; el alma te quiero dar porque buelbas a biuir,

13 O rei português compara-o a Camões (p. 142) e entrega-lhe o comando da infantaria.

14 Na verdade, as crónicas falam de um elmo e não de uma espada, como constata Queiroz Veloso (1935: 347). 
y te vuelva yo a matar.

(p. 149)

No final da comédia, o duque de Barcelos dirige-se ao público e pede desculpa pelos erros do seu rei:

Dando con aquesto fin

a nuestro Rey prodigioso,

y pidiendo juntamente

perdón de sus yerros todos.

(p. 154)

5. Nas páginas introdutórias da sua edição da Comedia famosa del rey don Sebastián, Werner Herzog situa a redação da peça de Vélez de Guevara pouco antes de março de 1607, que seria o seu limite máximo ad quem. Como fontes principais da comédia aponta, a par do livro intitulado Dell'unione del regno di Portogallo alla corona di Castiglia, de Ieronimo de Franchi Conestaggio (publicada em Génova em 1885, e rapidamente vertido para francês, inglês e espanhol) a própria Tragedia de D. Sebastián, de Lope, que teria sido redigida entre 1593 e 1603 (Herzog 1972: 24 e 34). Em Conestaggio teria encontrado a informação histórica e em Lope "una serie de elementos y recursos accidentales (id.: 39). Também Menéndez Pelayo (1969: 154) encarava o livro de Conestaggio como fonte única dos episódios relacionados com Alcácer Quibir na comédia de Lope de Vega. Werner Herzog chega mesmo a colocar lado a lado passagens da obra de Vélez de Guevara e das duas fontes que identifica para demonstrar a justeza da sua tese. É certo que há uma grande coincidência nestas três obras no que respeita à apreciação dos comportamentos dos dois reis peninsulares, que desresponsabiliza completamente o rei Filipe II e culpa D. Sebastião pela perda da independência de Portugal. Mas é difícil acreditar que, em data tão próxima dos acontecimentos, os dois dramaturgos não recorressem a outras fontes (obras acabadas de sair do prelo, nalguns casos, mas também possíveis manuscritos entretanto perdidos ou até testemunhos diretos, bem possíveis apenas 20 ou 30 anos depois da trágica batalha), tanto mais que o cotejo de textos a que procede Herzog não explica a origem de toda a informação manejada pelo autor da Comedia famosa del Rey don Sebastián.

As crónicas da jornada africana de $\mathrm{D}$. Sebastião não diferem substancialmente umas das outras na descrição dos acontecimentos, de forma que não é fácil detetar a fonte exata da informação utilizada por Lope ou Vélez de 
Guevara. Elas dão, de um modo geral, uma imagem positiva de Filipe II e de Mulei Maluco e extremamente negativa do rei marroquino aliado de D. Sebastião ${ }^{15}$. Também a historiografia moderna não discrepa muito das crónicas quinhentas e seiscentistas, como podemos verificar numa obra tão importante sobre período histórico como o D. Sebastião de J. M. de Queiroz Veloso. Vozes dissonantes, houve-as na época, como é o caso da Jornada de África, de Jerónimo de Mendonça (1607), e houve-as também modernamente, com destaque para o historiador Francisco Sales Loureiro, que não descreveu o Desejado como um lunático irresponsável, mas antes como um representante dos setores políticos e económicos portugueses que reprovavam o abandono das praças marroquinas empreendido por D. João III.

Francisco Sales Loureiro diverge igualmente da leitura benigna que as crónicas e as comédias fazem da ação e dos propósitos de Filipe II, sublinhando as boas relações comerciais do rei espanhol com os mouros marroquinos, aos quais vendia as armas por estes utilizadas na guerra contra as praças portuguesas, e o desencontro político e comercial entre os interesses de Filipe e os do estado português. $\mathrm{O}$ historiador luso encara o monarca espanhol como "um rei calculista, maquiavélico, que usa [em Guadalupe] da promessa ambígua para alimentar o jogo empreendedor do sobrinho; que, plenamente consciente dos efeitos negativos ou mesmos contrários da iniciativa, lhe desaconselha a empresa como forma de melhor a incentivar" (Loureiro 1989: 203-204). Assim explica Sales Loureiro as dificuldades colocadas por Filipe ao recrutamento em Espanha de militares para a expedição militar de D. Sebastião, considerando igualmente que o monarca espanhol, filho de mãe portuguesa, a imperatriz Isabel, "desde o seu casamento até à anexação do nosso país, sempre viveu tão obcecadamente a ideia de reinar em Portugal como o nosso rei a de governar na Mauritânia" (Loureiro 1989: 203) ${ }^{16}$.

15 Na Jornada del-Rei Dom Sebastião à África. Crónica de Dom Henrique, livro publicado em 1978, pela Imprensa Nacional-Casa da Moeda, sob a responsabilidade editorial de Francisco Sales Loureiro, Mulei Mohamed é nesta claramente denunciado como desonesto e mentiroso, conseguindo convencer em Ceuta D. António da Cunha de que era estimado pelos seus súbditos, quando, para o autor da Jornada, era Mulei Moluco que todos os mouros estimavam por ser "seu Rey natural, tido por muito caualeiro E amado dos seus por principe brando E afabel” (Jornada del-Rei 1978, 29). No prefácio (p. XXXVIII), Sales Loureiro data o manuscrito das duas crónicas do período que vai de 1588 a 1595. Menos objetivo no retrato de Mulei Moluco parece ser o "homem africano" que escreveu a Jornada de África del Rey D. Sebastão, e que se afirma contemporâneo dos acontecimentos que narra: "Era Maluc de gentil presença, discreto e mui bem entendido, branco e barbinegro, e em muitas virtudes que adornavam a sua pessoa mais parecia Cristão do que Mouro, entre as quais a justiça e um desejo de honra e liberalidade grande o faziam muito estimado (Jornada de África 2004: 35).

16 Para Maria Augusta Lima Cruz, os conselheiros mais sensatos do rei português terão regressado de Guadalupe a Portugal com acrescidos motivos de preocupação: "Conhecendo-o como conheciam, 
6. Como pudemos constatar, não constitui novidade a presença de temas e de figuras portuguesas no teatro espanhol do Século de Ouro. Isso deve-se, em primeiro lugar, a razões de proximidade ou mesmo de familiaridade, uma vez que o adjetivo espanhol (e a qualidade a que se associa) continuava a designar genericamente todos os habitantes da Península Hispânica, raras vezes nomeada como Ibérica.

Pode também dizer-se que em regra os Portugueses são tratados com o mesmo respeito que merecem aos dramaturgos de língua castelhana as demais nacionalidades peninsulares. Os traços caricaturais, quando existem, associados às personagens que encarnam o tipo dramático do gracioso, apontam para a hiperbolização das duas principais qualidades que se atribuem aos portugueses nas comédias áureas: a coragem física e a paixão descontrolada pela beleza feminina. E justamente o defeito capital captado por nuestros hermanos na personalidade lusitana é a compulsiva tendência para o exagero, ainda hoje plasmada no Diccionario da Real Academia Española: "portuguesada. f. Dicho o hecho en que se exagera la importancia de algo" (http:// lema.rae.es/drae/?val=portuguesada; consult. 28/9/2015).

No caso do retrato do rei D. Sebastião que é feito nas duas obras estudadas não se pode, obviamente, falar de caricatura, mas sim de excesso e tragicidade. $\mathrm{O}$ excesso traduz-se em arrogância e em cegueira pessoal, social e política. Mas a descrição das ações temerarias do rei a que se procede nas comédias não é uma arbitrariedade dos dramaturgos, porque a perspetiva nelas apresentada coincide quase integralmente com o que sobre o mesmo rei registaram as crónicas coevas, incluindo as que foram escritas por autores portugueses. É com base nelas que Queiroz Veloso, um dos seus melhores conhecedores, traça este retrato de um rei que já fora e voltaria a ser desejado:

Quanto mais o contradiziam, mais se aferrava ao seu projeto. Era uma teimosia mórbida, a cerrada obstinação de um pensamento dominante: os avisos, por mais prudentes, a mínima oposição, por mais sensata, em vez de o convencerem, irritavam-no, afervorando-o no seu empenho. Outra preocupação constante é a sua reputação, o que dirá o mundo, o que escreverão os cronistas. (Veloso 1935: 269) ${ }^{17}$

não ignoravam que as condições impostas por Filipe II teriam o efeito perverso de o impelir à vertiginosa tarefa de preparar em oito meses uma expedição militar cuja envergadura ultrapassava, agora, tudo quanto antevira. Circunstância que, por certo, ainda mais o motivaria” (Cruz 2011: 255).

17 José van den Besselaar, um reconhecido especialista holandês da temática do Sebastianismo, traçou um perfil da personalidade de D. Sebastião ainda mais expressivo: "Destituído de qualquer realismo, andava alheio às grandes necessidades da nação, como também ao espírito da época em que a Europa acabava de entrar. Extraviado, vivia na Idade Média, e sonhava com atos de bravura cavaleiresca e 
Até mesmo a prudência de Filipe II e a seu aparente desinteresse pela coroa de Portugal (que, como vimos, Francisco Sales Loureiro questiona) são confirmados pelas crónicas, tal como a desonestidade do xarife a que se associa o rei português. Mas isto não significa necessariamente que nas duas comédias esteja completamente ausente o fundamento ideológico. Apesar se tratar, antes do mais, de um espetáculo e de um negócio, que tem de assegurar o sustento da companhia, o teatro espanhol do Siglo de Oro tem também uma agenda ideológica que passa pela apologia do centralismo régio (incarnado na dinastia dos Habsburgos espanhóis) e pela exaltação da fé católica. D. Sebastião nunca é explicitamente desrespeitado, porque, enquanto rei legítimo, o seu poder tem origem divina, mas, na exata medida em que o decoro o permite, é realçado o seu caráter aventureiro e sua falta de sentido de estado, que não é completamente compensada pela sua coragem e destreza militar.

Também não deve ter sido alheio a este interesse pelo perfil histórico de D. Sebastião o facto de, pelos mesmos anos, começar a desenhar-se em Portugal um culto messiânico em torno da memória do falecido rei, ao mesmo tempo que se ampliava a disseminação da lenda da intervenção divina na formação de Portugal. De acordo com essa lenda, gradualmente integrada nas crónicas lusas, Cristo Crucificado aparecera a D. Afonso Henriques na véspera da batalha de Ourique, garantindo-lhe a vitória e outorgando-lhe poderes régios. Frei Bernardo de Brito relata o milagre de Ourique na sua Crónica de Cister (1602), enquanto Frei António Brandão o fará na III parte da sua Monarquia Lusitana (1632). É sabido que nos anos que se seguiram à batalha de Alcácer Quibir apareceram vários burlões que tentaram fazer-se passar por D. Sebastião, regressado vivo de África. Um desses aventureiros, o italiano Marco Tulio Catizzone, logrou mesmo convencer alguns nobres portugueses, entre os quais D. João de Castro, de que era o monarca desaparecido (cf. Besselaar 1987: 68-71). D. João de Castro, neto do homónimo Vice-Rei da Índia, que fora partidário do prior do Crato na resistência a Filipe II, publicou em 1602, em Paris, onde se encontrava exilado, o Discurso da Vida do Sempre Bem-Vindo e Aparecido Rei Dom Sebastião, Nosso Senhor, o Encuberto, des do seu Nascimento té o Presente, e no ano seguinte a primeira versão impressa das trovas de Bandarra (Paráfrase e Concordância de Algüas

com louros militares, sobrestimando as suas forças. Não se lhe pode negar certa grandeza e certo idealismo, mas essas boas qualidades eram comprometidas por uma grande dose de teimosia, fanatismo e egocentrismo" (Basselaar 1987: 68-69). 
Profecias de Bandarra, Sapateiro de Trancoso), que se tornaria uma obra de referência para a oposição portuguesa à governação filipina.

Face à lenda que se ia formando e voando para o céu, nada melhor do devolver à terra (e à sua dimensão natural) um rei que, como reconhece Basselaar (id.: 75) nunca, fora particularmente compreendido e acarinhado pelos seus súbditos. E se a independência de Portugal se legitimara (segundo a crença generalizada dos portugueses) na intervenção divina em Ourique, também a perda da independência tem uma legitimação sobrenatural avalizada nestas comédias, particularmente na de Vélez de Guevara, na qual abundam os sinais de que os céus não estavam com o rei português e de que a sua abnegada empresa estava votada a um completo fracasso do qual fatalmente resultaria o fim de um Portugal independente ${ }^{18}$.

\section{Referências}

BESSELAAR, José van den (1987). O Sebastianismo - História Sumária. Lisboa: Instituto de Cultura e Língua Portuguesa.

BRUNO, Sampaio (1983). O Encoberto. Porto: Lello \& Irmão.

BOUZA, Fernando (2011). D. Filipe I. Lisboa: Círculo de Leitores.

CAMÕES, Luís de (2003). Os Lusíadas. 5. a ed. Ed. Á. J. Costa Pimpão. Lisboa: Instituto Camões.

CORREAS, Gonzalo (2000). Vocabulario de refranes y frases proverbiales. Ed. Louis Combet, revista por Robert Jammes y Maïte Mir-Andreu. Madrid: Castalia.

CRUZ, Maria Augusta Lima (2011). D. Sebastião. 6.a ed. Lisboa: Círculo de Leitores.

DOMÍNGUEZ ORTIZ, Antonio (1973). El Antiguo Régimen: Los Reyes Católicos y los Austrias. Madrid: Alianza/Alfaguara.

FRAY PRUDENCIO DE SANDOVAL (1956). Historia de la vida y hechos del Emperador Carlos V, Máximo, fortísimo, Rey Católico de España y de las Indias, Islas y Tierra firme del mar Océano. Vol. III. Madrid: Ediciones Atlas.

HERZOG, Werner, 1972. [Introdução] a Comedia famosa del Rey don Sebastián. Madrid: Anejos del Boletín de la Real Academia Española.

Jornada de África del Rey D. Sebastião Escrita por um Homem Africano (2004). Prólogo de Júlio da Conceição Pedro; atualização ortográfica de Fernando Calapez. Lisboa: Livro Aberto.

18 Recordemos as palavras dirigidas ao rei pela morte, que lhe aparece sob forma de mulher: “ $¡ N o$ des la batalla, Rey, / buélbete al mar, alça el canpo, / que ynporta a tu bida hacello / y al honor de tus basalhos!” (p. 136) 
Jornada del-Rei Dom Sebastião à África / Crónica de Dom Henrique (1978). Lisboa: Imprensa Nacional-Casa da Moeda.

LOUREIRO, Francisco Sales (1983). “D. Sebastião e Alcácer Quibir”, in José Hermano Saraiva, ed. História de Portugal. Vol. IV. Lisboa: Publicações Alfa, 127-159.

LOUREIRO, Francisco Sales (1989). D. Sebastião e Alcácer Quibir. Lisboa: Publicações Alfa.

MENÉNDEZ PELAYO, Marcelino (1969). “La tragedia del rey don Sebastián y bautismo del príncipe de Marruecos”, in Obras de Lope de Vega. Vol. XXV. Madrid: Atlas, 150-155.

QUADROS, António (1982). Poesia e Filosofia do Mito Sebastianista. Vol. I. Lisboa: Guimarães \& C. ${ }^{a}$.

QUEVEDO, Francisco (1973). Sueños y discursos. Ed. Felipe Maldonado. Madrid: Castalia.

RAPOSO, Hipólito (1936). “O sentimento português em Lope de Vega”, Gil Vicente, vol. XII, $11-18,51-62$ e 87-100.

SAN ROMÁN, Antonio de (1603). Jornada y muerte del rey don Sebastián de Portugal. Valladolid: Herederos de Juan Yñiguez de Lequerica.

VEGA, Lope de (1925). Comedias escogidas. Vol. III (Biblioteca de Autores Españoles, tomo XLI). Madrid: Librería y Casa Editorial Hernando.

VEGA, Lope de (1955). Obras escogidas. Tomo III. Ed. F.C. Sainz de Robles. Madrid: Aguilar.

VEGA, Lope de (1966). El duque de Viseo. Ed. F. Ruiz Ramón. Madrid: Alianza.

VEGA, Lope de (1967). Arte nuevo de hacer comedias; La discreta enamorada. 3. a ed. Madrid: Espasa-Calpe.

VEGA, Lope de (1969). La tragedia del rey don Sebastián y bautismo del príncipe de Marruecos. Comedia famosa, in Obras de Lope de Vega. Ed. M. Menéndez Pelayo. Vol. XXVII. Madrid: Atlas, 123-182.

VÉLEZ DE GUEVARA, Luis (1964). Reinar después de morir. Madrid: Editora Nacional.

VÉLEZ DE GUEVARA, Luis (1972). Comedia famosa del rey don Sebastián. Ed. Werner Herzog. Madrid: Anejos del Boletín de la Real Academia Española.

VÉLEZ DE GUEVARA, Luis (2014). La jornada del rey don Sebastián. Ed. William R. Manson e C. George Peale. Newark, Delawre: Juan de la Cuesta.

VELOSO, J. M. de Queiroz (1935). D. Sebastião: 1554-1578. Lisboa: Empresa Nacional de Publicidade.

VIQUEIRA, José María (1950). El lusitanismo de Lope de Vega y su comedia "El Brasil restituido". Estudio bio-bibliográfico, notas y comentários. Coimbra: FLUC-Coimbra Editora. 



\title{
El discurso judiciario sobre Don Sebastián y el cometa de $1577^{*}$
}

\section{The astrological forecasts about Don Sebastian and the comet of 1577}

\author{
JESÚS M. UsUNÁRIZ \\ Universidad de Navarra - GRISO \\ jusunariz@unav.es
}

Texto recebido em / Text submitted on: 31.08.2015

Texto aprovado em / Text approved on: 30.09.2015

Resumen: El cometa de 1577 ha pasado a la Historia asociado al rey Don Sebastián de Portugal (1578) y a los 'pronósticos' y valoraciones que se hicieron antes y después de su muerte. Además, los autores de estos trabajos participaron de los debates científicos del momento sobre la naturaleza de los cometas. No obstante, muchas de estas crónicas y relaciones que dieron noticia del paso del cometa contenían una intencionalidad política de justificación de los acontecimientos que se siguieron, especialmente de la unión de Portugal a la Monarquía Hispánica.

Palabras clave: Cometas. Astrología. Portugal. 1577. Don Sebastián.

Abstract: The comet of 1577 has been associated with the history and the death of the King Sebastian of Portugal (1578), and the 'forecasts' and assessments that were made before and after his death. Furthermore, the authors of these publications participated in the scientific debates of the moment about the nature of comets. However, many of these chronicles and spanish news («relaciones de sucesos») about the passage of the comet had a political purpose to justify the future events, especially the union of Portugal to the Spanish monarchy.

Keywords: Comets. Astrology. Portugal. 1577. Don Sebastian

\section{La aparición del cometa y sus predicciones. "Mire Portugal por sí. Guárdese África”.}

En 9 días del mes de noviembre de 1577 años -según escribe en sus Memorias, fray Juan de San Gerónimo-, a las seis horas de la noche, en la conjunción de la luna, salió un cometa a la parte del poniente sobre la sierra de San Benito, que está junto a Robledo de Chavela (Madrid), el cual cometa despedía una

* Este trabajo forma parte de los resultados del proyecto Discurso y poder, lengua y autoridad en el mundo hispánico (siglos XVI-XVII), HAR2012-31536, subvencionado por el Ministerio de Economía y Competitividad. 
bella cabellera, grande y ancha y muy clara, que provocaba a dar gracias a Dios, viendo y considerando su hermosura. La raíz estaba hacia Portugal y la cabellera señalaba hacia Valencia. Su color era blanco a manera de plata [...]. Echaron luego juicios sobre este cometa y decían que amenazaba a Portugal y que denotaba sequedad y muerte de príncipes $^{1}$.

El cometa de 1577, de "aspecto amenazador"2, conocido oficialmente en la actualidad como C/1577 V1, fue visto y observado en gran parte del mundo. Muy pronto, a finales de ese año, comenzaron a publicarse los primeros estudios sobre su avistamiento en Alemania, Dinamarca, Países Bajos, España, Portugal, Francia, Italia ... Más de cien títulos, recogidos en su día por Doris Hellman ${ }^{3}$, y en los que intervinieron astrónomos y físicos del prestigio del danés, Tycho Brahe $(+1601)$ o de los alemanes Michael Maestlin (+1631), maestro de Kepler, o Helisaeus Roeslin (+1616).

En España tres fueron los autores fun-

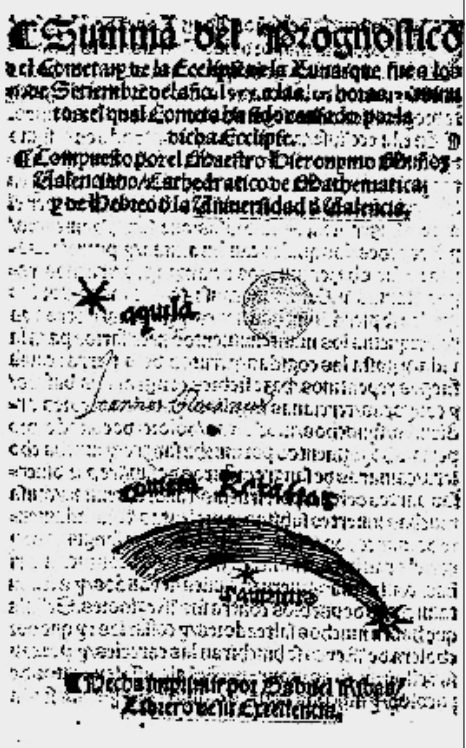
damentales que, como fruto de sus observaciones científicas, sacaron a la luz publicaciones sobre el cometa poco después de su paso ${ }^{4}$. El primero, el afamado astrónomo y hebraísta valenciano Jerónimo Muñoz (1520-1591), estudioso de la nova de 1572, y autor de la Suma del prognóstico del cometa y de la eclipse de la luna (Valencia, Joan Navarro, 1578), año en el que fue nombrado catedrático de matemáticas en la universidad de Salamanca.

Fig. 1.

Muñoz, Jerónimo, Suma del prognóstico del cometa (Valencia, 1578)

1 San Gerónimo, fray Juan de (1845). "Memorias" in Colección de documentos inéditos para la historia de España. t. 7, Madrid: Viuda de Calero, 212-213.

2 Cabrera de Córdoba, Luis (1619). Filipe segundo rey de España. Madrid: Luis Sánchez, 962.

3 Hellman, C. Doris (1944). The Comet of 1577: Its Place in the History of Astronomy. New York: AMS Press.

4 Navarro Brotons, Víctor (2012). "Las novedades celestes en España entre 1572 y 1618”, in Granada, M. A. ed. (2012). Novas y cometas entre 1572 y 1618. Revolución cosmológica y renovación política y religiosa. Barcelona: Universidad de Barcelona, 15-41.

5 https://books.google.es/books?id=kkOFGh69nQUC 


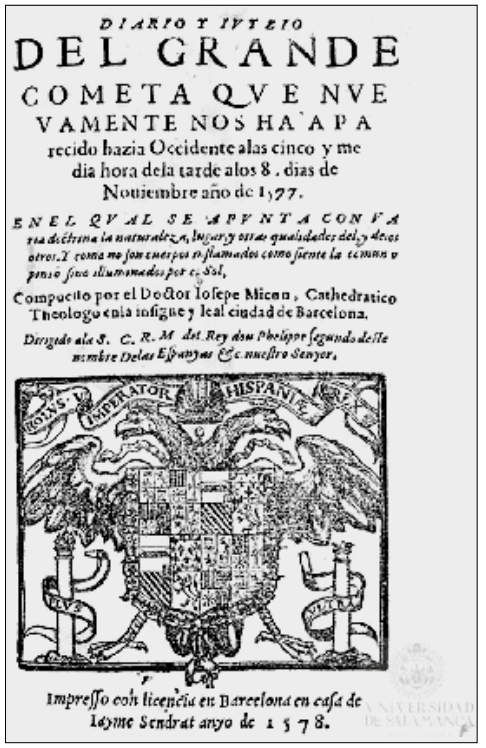

SRE COMAIS,

Et prodigiofis eorum por - $\cdots$....... tentis, libriquatuor.

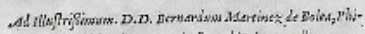

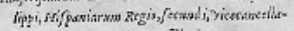

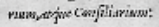

C Francilcu EermamderRaxn, Aragonicnfi

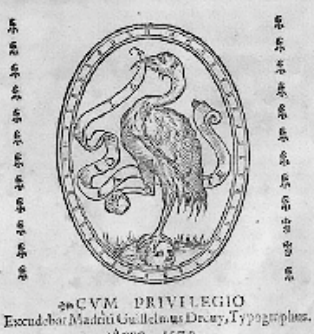

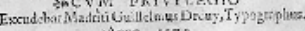
Arino 4578
El catalán Josep Micó, titular de la cátedra de matemáticas y astrología, desde 1576, en la Universidad de Barcelona, y cuya única obra editada fue el Diario del juicio del grande cometa que nuevamente nos ha aparecido (Barcelona, Jaime Sendrat, 1578).

\section{Fig. 2.}

Micó, Josep, Diario del juicio del grande cometa que nuevamente nos ha aparecido (Barcelona, 1578) ${ }^{6}$.

Y, finalmente, el aragonés Francisco Fernández Raxo y Gómez (+1605), turolense, catedrático de Medicina en la universidad de Valencia y médico de cámara de Felipe II, autor del libro De cometis et prodigiosis eorum portentis libri quatuor (Madrid, Guillemus Drouy, 1578) ${ }^{7}$.

Fig. 3.

Fernández Raxo y Gómez, Francisco, De cometis et prodigiosis eorum portentis libri quatuor (Madrid, 1578) ${ }^{8}$

6 Gredos. Repositorio documental de la Universidad de Salamanca. http://hdl.handle. net/10366/83115.

7 Hay también un manuscrito Diálogo en declaración del discurso y significaciones del cometa que se vio a 9 de noviembre de 1577, que se encuentra en la Biblioteca del Palacio Real de Madrid. Ha sido estudiado por Gómez Crespo, Félix and Esteban Piñeiro, Mariano and Jalón Calvo Mauricio (1993). "Astrología en el siglo XVI. Un nuevo tratado sobre el cometa de 1577", in Actes de les II Trobades d'Història de la Ciència i de la Tècnica: (Peníscola, 5-8 desembre 1992). Barcelona: Institut d'Estudis Catalans, 263-272.

8 Biblioteca Virtual del Patrimonio Bibliográfico. http://bvpb.mcu.es/es/consulta/registro.cmd?control=BVPB20101001691 
Estos autores, insertos en el debate científico de su tiempo, no eludieron en sus obras la polémica entre "sideralistas" y "exhalacionistas". Los segundos, mantenían las tesis aristotélicas por las que defendían el origen metereológico de los cometas, fruto de las exhalaciones de vapores desde la tierra, provocadas por el astro sol. Al contrario, los sideralistas los juzgaban como fenómenos celestes insertos en el sistema planetario9. Tanto Muñoz, como Micó -como Tycho Brahe-, se adelantaron así al proceso de rechazo de la cosmología aristotélica que iría avanzando, con nuevos descubrimientos, a lo largo de todo el siglo XVII ${ }^{10}$.

De los tres españoles citados, los trabajos más extensos y completos fueron los de Micó y Fernández Rajo, pero los tres -incluido el de Muñozanalizaban el origen, forma, color y recorrido del cometa, con todo género de detalles e hicieron sus mediciones.

Todos aprovecharon la ocasión, como era tradicional en este tipo de obras, para hacer sus pronósticos, a partir del análisis de las características del meteoro. El citado Tycho Brahe, predijo, dado que el cometa había aparecido bajo el signo de Sagitario, la muerte de un rey y de autoridades en España, así como una guerra civil por divisiones religiosas ${ }^{11}$. Un astrólogo del rey de Francia, desconocido, citado por Micó, también anunció la muerte del príncipe de España ${ }^{12}$.

Evidentemente, y gracias a una larga tradición, los augurios de los cometas, no podían ser buenos:

9 Iriarte, Joaquín (1996). La canción del cometa de 1577: un médico renaciente, Francisco Sánchez, en lucha con la astrología. Una página de la física aristotélica que se desploma con estrépito. Una página de las Cortes de Madrid y Lisboa completamente inédita, Bilbao: Universidad de Deusto. Un buen resumen de este debate en Carolino, Luís Miguel (2004). "O Ensino de Filosofia Natural nas Universidades Portuguesas: ideias e percursos académicos, 1550-1650”, in Estudos em Homenagem a Luís António de Oliveira Ramos. Porto: Faculdade de Letras da Universidade do Porto, vol 1, 371-378.

10 Navarro Brotons, Víctor, "Las novedades celestes... cit", 15. O Trabulse: "Estos estudios sobre los cometas y su influencia maligna en el mundo forman uno de los más interesantes capítulos de la historia del nacimiento de la ciencia moderna, ya que en ellos se mezcla la visión mítica del cosmos, con la nueva visión científica. Son los documentos idóneos para estudiar el tránsito de la astrología judiciaria a la astronomía científica, o sea de la concepción medieval del cosmos a la nueva cosmología mecanicista del universo, que lograba su consagración en las dos últimas décadas del siglo XVII”. Trabulse, Elías (1974). Ciencia y religión en el siglo XVII. México: El Colegio de México, 1. Sobre el debate iniciado a partir de 1577, es de gran interés el trabajo de Nouthuys, Etabita van (1988). The Age of Two Faced Janus. The Comets of 1577 and 1618 and the Decline of the Aristotelian World View in the Netherlands. Leiden, Brill, si bien circunscrito al ámbito de los Países Bajos.

11 Goodman, David C. (1988). Power and Penury: Government, Technology and Science in Philip II's Spain. Cambridge: Cambridge University Press, 99.

12 Micón, José (1578). Diario del juicio del grande cometa que nuevamente nos ha aparecido. Barcelona: Jaime Sendrat, cap. 49. 
Lo que yo podré decir -escribía Illescas en 1602- es que de la continua lección de las historias antiguas y modernas y de varios autores, poetas y oradores, he colegido que nunca hasta hoy en el mundo se vieron semejantes impresiones en el aire, que no sucediesen dentro de uno o dos o a lo más tres años, notables desastres y calamidades en las partes adonde los tales planetas o fuegos ame$\operatorname{nazan}^{13}$.

Según Muñoz, el de 1577 anunciaba plagas de sabandijas, luchas "entre principales señores y deudos, grandes revueltas, disensiones y guerras”, por su forma de bocina; "rencillas entre gente popular y muerte de príncipes, daños grandes a las preñadas y paridas, corrupción de los frutos de la tierra" además del peligro de hambres, pestes y enfermedades "melancólicas" ("como son catarros, asmas, gota coral, perlesía, cuartanas, sarampión o tabardete, zaratanes, cancros, sarna, lepra, mal francés, almorranas”). Una de las regiones más afectadas, entre otras, sería Berbería ${ }^{14}$. Por su parte, Micó evitaba tratar de enfermedades, rechazaba que el cometa señalase siempre la muerte de príncipes y reyes, pero sí estimaba que su paso era el anuncio de "sediciones, scismas, rebeliones de vasallos contra sus señores", además de gran frío y abundantes aguas, siendo especialmente afectada África, ya que la cola del cometa "fue extendida hacia el mediodía", "y aun el reino de Portugal, con dos o tres ciudades de España y algunas de Italia ${ }^{15}$.

Los pronósticos, no muy precisos, hicieron que las primeras reacciones de algunos consejeros áulicos de Felipe II dirigieran sus miras hacia los sediciosos Países Bajos. El astrólogo napolitano Giovanni Battista Gesio, que residía en Madrid desde 1560, instó al rey en 1578 a que interviniese en los Países Bajos de acuerdo a los signos de los cielos; y, de hecho, el gobernador, Juan de Austria, emprendió una campaña contra los rebeldes en enero de 1578 con el notable éxito de la batalla de Gembloux, que permitió la recuperación de una gran parte del territorio sublevado ${ }^{16}$.

13 Illescas, Gonzalo (1652). Historia Pontifical y Católica. Madrid: Gabriel de León, fol. 362v. Algo similar afirma Antonio Seyner en 1644: "Raro ha sido el suceso (que siendo en la admiración grande) no haya dado el cielo anticipadas señales de el que amenaza futuro en anticipados prodigios. Porque en lo desusado de una señal rara, se recele (como un presagio) el daño que amenaza lastimoso. Los cometas distintos (como de distintas formas) son el desempeño de la propuesta, cuando siempre se les ha seguido (rara vez ha faltado) el daño que manifestó la experiencia”. Seyner, Antonio (1644). Historia del levantamiento de Portugal. Zaragoza: Pedro Lanaja y Lamarca, 2-3.

14 Muñoz, Jerónimo (1578). Suma del prognóstico del cometa y de la eclipse de la luna. Valencia: Joan Navarro.

15 Micón, José - Diario del juicio... cit., caps. 40 y 48.

16 Goodman, David C..Power and Penury... cit., 7. 
No obstante, quien tuvo un indudable acierto en su predicción sería Fernández Rajo, pues en su citada obra declaraba:

Los cometas anuncian muerte de reyes y reinas y de varones ilustres. Pues además de lo que antes en el libro 20 dijimos según S. Juan Damasceno y otro, cuando apareció distaba del sol en once signos; y se le vio primero en el ángulo de occidente, lo que viene a confirmarse con la sentencia de Ptolomeo. De lo cual pueden hacerse deducciones. $\mathrm{Y}$ aunque mientras escribimos esto, se nos anuncia la muerte de la serenísima reina de Portugal [el 12 de febrero de 1578], no creemos que basta ello para tan gran prodigio. No es tan cierto que amenace a nuestros católicos reyes de Castilla, pues no ha estado perpendicular a estas regiones, ni se que tengan lugar alguno en Sagitario. Lo que no quiere decir que amenace a los seculares de Portugal. Y a los príncipes eclesiásticos amenaza desde luego más que a cualesquiera españoles"17.

Tal 'ajustado' vaticinio sería reconocido pocos años más tarde por otro turolense, el historiador Bernardino Gómez Miedes, que en 1584, escribía:

en el tiempo que apareció el cometa, y muchos días antes que desapareciese, entre otros publicó un pronóstico, que leímos, de un doctísimo astrólogo aragonés, el cual claramente afirmaba que las ruinas y calamidades grandes que el cometa anunciaba, todas se enderezaban contra Portugal y África y el autor concluía con estas palabras: "Mire Portugal por sí, guárdese África"18.

O de manera más exagerada y distorsionada, Pedro Sánchez de Acre, que en 1590, al tratar sobre la muerte del rey Don Sebastián, afirmaba:

Y aun no faltaron algunos astrólogos en su reino que le disuadieron este viaje, especialmente un aragonés, que publicó un discurso judiciario de que advirtió al rey, diciendo que mirase lo que hacía, porque un cometa que se había mostrado en el aire le amenazaba de muy gran peligro, porque su cola se extendía hacia África, adonde él había de ir con su armada y su postura era contra Portugal. Y que muchas veces estos cometas eran pronóstico de muertes de príncipes. Y daba voces, viendo que no se tomaba su consejo diciendo: 'Mire Portugal por sî'19.

17 Fernández Rajo, Francisco (1578). De Cometis et prodigiosis eorum portentis, libri quatuor. Madrid: Guillelmus Dreuy, fol. 88v-89r. La traducción es de Iriarte, Joaquín. La canción del cometa ... cit., 86.

18 Gómez Miedes, Bernardino (1584). La historia del muy alto e invencible rey don Jaime de Aragón, primero de este nombre, llamado el conquistador. Valencia: Pedro de Huete, 280. También lo hizo Salazar de Mendoza, Pedro (1770). Monarquía de España. Madrid: Joaquín Ibarra, t. 2, 216.

19 Sánchez de Acre, Pedro (1590). Historia moral y filosófica en que se tratan las vidas de doce filósofos y príncipes antiguos. Toledo: Viuda de Juan de la Plaza, fol. $37 \mathrm{v}$. 
No fueron, por supuesto, los únicos hechos maravillosos, "divinas amonestaciones” en palabras de Diego de Yepes, que sucedieron aquel año, pues al cometa acompañaron o lo anticiparon, fuegos grandes y espantosos en el cielo, contagios, "abortos de animales extraordinarios", ejércitos de hombres armados por el aire, multitud de mosquitos, águilas sobrevolando el castillo de Lisboa, fantasmas, apariciones y otros infelices presagios ${ }^{20}$.

Que el cometa, u otras revelaciones, amenazaran a los reyes, príncipes seculares y eclesiásticos de Portugal, tendría su confirmación el 4 de agosto de 1578, cuando tras una penosa expedición, moría en la batalla de Alcázarquivir el joven monarca Sebastian I de Portugal, su aliado, el sultán destronado Moulay Mohammed al-Mutawakkil, y varios miles de portugueses perecían o eran hechos cautivos por las tropas marroquíes de Muley Abd al Malik (el Maluco de las crónicas), que también pereció en la refriega. Desde la trágica muerte del rey, aquel cometa que meses antes había atravesado los cielos, se convirtio en el símbolo y seña por antonomasia de la muerte de un rey: el "cometa sebástico"21.

20 Castro, Joao de (1602). Discurso da vida do sempre bemvindo et apparecido rey Dom Sebastiam. Paris: Martin Verac, fol. 29v-30r; Yepes, Diego de (1592). Discursos de varia historia. Toledo: Pedro Rodríguez, fols. 9r-9v; Díaz, Nicolás (1599). Tratado del juicio final, en el cual se hallarán muchas cosas curiosas y provechosas para la salud de las almas y recreación de los que las leyeren. Madrid: Luis Sánchez; Seyner, Antonio. Historia del levantamiento... cit., 2-3; Faria y Sousa Manuel (1680). Europa portuguesa. Segunda edición. t. 3. Lisboa: Antonio Craesbeeck, 142-143; Baena Parada, Juan de (1692). Epítome de la vida y hechos de don Sebastián. Madrid: Antonio González de Reyes, 53. Recogidos también por Santos, Ilda dos (2000). "Le temps d'un roi. Prophéties et conquêtes à l'époque de Sébastien du Portugal (1554-1578), in Redondo, A. ed. (2000). La prophétie comme arme de guerre des pouvoirs (XVe-XVIIe siècles). Paris: Presses de la Sorbonne Nouvelle, 109-122 o Mackay, Ruth (2012). The Baker Who Pretended to Be King of Portugal. Chicago: The University of Chicago Press, 16ss. Son también curiosos gran número de prodigios que suceden en Europa en torno a 1577 y 1578 en el manuscrito de Fray Juan de la Victoria, Libro de los cometas, fenómenos y portentos, BNE, mss. 880, cap. 42 y especialmente los fols. 126r-126v en donde asocia el cometa y otros hechos sobrenaturales a la muerte del rey D. Sebastián:

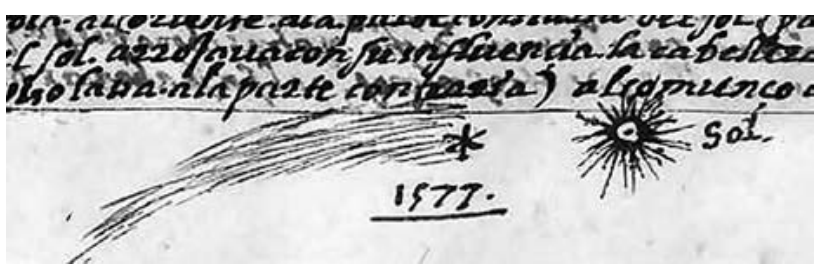

Fig. 4.

Victoria, Fray Juan de la, Libro de los cometas, fenómenos y portentos, BNE, mss. 880

(Biblioteca Digital Hispánica http://bdh-rd.bne.es/viewer.vm?id=0000139651\&page=1)

21 Sobre el consenso existente entre los astrólogos portugueses contemporáneos al asociar el cometa de 1577 con los sucesos de 1578, ver Carolino, Luís Miguel; Camenietzki, Carlos Ziller (2006). “Tokens of the future: comets, astrology and politics in early modern Portugal”, Cronos, 9, 33-57. 
A partir de ese momento, las interpretaciones sobre el paso del cometa iban destinadas a justificar los movimientos que siguieron a la muerte del monarca Avis y a la del rey cardenal Enrique en 1580. De hecho, el citado astrólogo de Felipe II, Gesio, que trabajaba en la embajada del rey en Lisboa, sería uno los primeros en elaborar un discurso favorable a los derechos de Felipe II sobre el reino de Portugal, apoyado en el anuncio de los mismos fenómenos celestes, no solo el cometa de 1577, sino también el eclipse y el cometa de 1580 en el momento de la muerte del rey cardenal ${ }^{22}$.

\section{Fatalismo, libre albedrío y crítica política}

No sabemos lo que sinifican estas cosas, ni lo que amenazan. Han empero, causado mucho temor y con razón, porque siempre semejantes señales sinifican y son pronósticos de algunos males que han de acaecer ${ }^{23}$.

No es ni mucho menos extraña la asociación entre el paso del cometa de 1577 y la incorporación del reino de Portugal ("la pérdida de Portugal" de la que hablan los autores lusos) a la monarquía hispánica, pues, tradicionalmente, la muerte de principes y la mudanza de reinos eran dos de los varios efectos que causaban en el mundo terrenal. Los cometas provocaban la muerte de principes ya que se consideraba que estos eran "más delicados" y más afectados por el aire corrompido exhalado por la estela del astro ${ }^{24}$. La caidade imperios, y los cambios en los reinos, era una interpretación tradicional, que se remontaba a la autoridad de Lucano o de Plinio quienes veían en los cometas el presagio de "mutaciones de reinos"25. Creencia, por otro lado, muy popular y extendida: "la opinión del vulgo -escribe el padre Mariana,

22 Goodman, David C. Power and Penury..., cit., 7.

23 Díaz, Nicolás. Tratado del juicio final..., cit.,156-157.

24 Micón, José. Diario del juicio..., cit., cap. 32; Conestaggio, Geronimo de Franchi (1610). Historia de la unión del reino de Portugal a la corona de Castilla. Barcelona: Sebastián de Cormellas, fol. 15v; Herrera y Tordesillas, Antonio de (1601). Segunda parte de la Historia General del Mundo de XI años del tiempo del señor rey don Felipe II, el prudente, desde el año de MDLXXV hasta el de MDLXXXV. Madrid: Pedro Madrigal, 109; San Román, Antonio de (1603). Jornada y muerte del rey don Sebastián de Portugal, sacada de las obras de Franchi, ciudadano de Génova. Valladolid, Juan Íniguez de Lequerica, 40-42; Mesa, Sebastián de (1630). Jornada de África por el rey don Sebastián y unión del reino de Portugal a la corona de Castilla. Barcelona: Pedro Lacaballería, fol. 50v. Al respecto, Varela, Javier (1990). La muerte del rey. El ceremonial funerario de la monarquía española 1500-1885. Madrid: Turner, 100.

25 Macías Villalobos, Cristóbal (2006). "Los cometas en el mundo antiguo: entre la ciencia y la superstición”, Veleia: Revista de prehistoria, historia antigua, arqueología y filología clásicas, 23, 58-59, 62, 68-69 
al mencionar el fenómento de 1577- es que el cometa pronostica mudanza de rey"26.

Ahora bien, esta astrología judiciaria, sujeta a unos esquemas basados en la una tradición interpretativa clásica, en los testimonios históricos, y en las 'observaciones empíricas' a lo largo de los siglos, a pesar de su éxito en todos los ámbitos sociales, podía provocar serios problemas a sus fautores, pues pronósticos de este tipo chocaban, lógicamente, con la ortodoxia católica, al poner en tela de juicio la omnipotencia divina, que parecía quedar al margen del orden de los cielos, y el libre albedrío humano desaparecía bajo el fatalismo ineludible de los astros, y, en consecuencia, de la predestinación. De ahí que los astrólogos pronosticadores tuvieran particular cuidado en apuntar ideas que recalcasen la ortodoxia de sus exposiciones.

Muñoz finalizaba su breve pronóstico con una sentencia: "No son los juicios de los astrólogos necesarios, sino contingentes, ut plurimum, y Dios puede hacer lo que quisiere de los efectos de los cielos, así como los hizo de la nada" ${ }^{27}$. Micó sostenía que no se podía "hacer juicio acertado, ni se debe" sobre el paso de los cometas, pues eran advertencias de Dios a los hombres "para que vivan recatados"; y, por tanto, "no conviene que le atemos con sus mesmos instrumentos", pues solo Dios sabía cómo y cuándo debían disponerse las cosas, y más aún en materia de reyes y príncipes, pues, como sentenciaba el mismo Dios, "Per me reges regnant"

Bien es cierto, que los autores $-\mathrm{y}$ sus lectores- mantuvieron una cierta ambivalencia: si, por un lado, se hicieron eco del éxito de las predicciones astrológicas, por otro introdujeron textos para salvaguardar el poder divino y la libertad humana. Horozco y Covarrubias estimaba que los juicios habían acertado al interpretar el gran cometa de 1577, pues "se había cumplido la propiedad, que referimos de Lucano, tenía la cometa de mudar los reinos" 29 . El padre José de Sigüenza habló del "cometa famoso" de 1577, para valorar positivamente los pronósticos que se hicieron: "Cuán verdadero fue el juicio, hasta ahora lo lloran los portugueses y los castellanos no enjugarán tan pronto

26 Mariana, Juan de (1685) Historia general de España. Madrid: Francisco Martínez, tomo segundo, 761; o Seyner, Antonio, Historia del levantamiento... cit., 2-3: "No se deben acreditar en nuestros discursos anuncios semejantes $y$, con todo, la experiencia de tantos ha podidos llevarse (sin perjuicio de lo católico), la que credulidad que basta, que en los talentos rudos no es poca”.

27 Muñoz, Jerónimo, Suma del prognóstico... cit.

28 Micón, José. Diario del juicio... cit., cap. 34.

29 Horosco y Covarrubias, Juan de (1588). Tratado dela verdadera y falsa profecía. Segovia: Juan de la Cuesta, fol. 125v. Sobre esta actitud ambivalente hacia la astrología judiciaria Magnier, Grace (2010). Pedro de Valencia and the Catholic Apologists of the Expulsion of the Moriscos. Visions of Christianity and Kingship. Leiden: Brill, 126-129. 
las lágrimas" ${ }^{30}$. En sus Memorias, fray Juan de San Gerónimo consideraba que el cometa lo había anunciado:

Bien claramente se ha entendido haber obrado el cometa que salió el noviembre pasado de 1577 años, donde amenazaba según el pronóstico a las cabezas de Portugal, diciendo de esta manera: En España faltarán algunos grandes señores. Guarde Dios a los mayores de Portugal ${ }^{31}$.

Francisco de Santa María, en 1644, dio noticias del cometa, que "causó grande admiración" y concluye: "Varios juicios oímos. Los que dijeron significar la muerte de algún príncipe, se acreditaron con la del rey don Sebastián de Portugal, que sucedió al año siguiente" ${ }^{32}$. Rodrigo Zamorano, autor de una Cronología (1594) se presentaba sentencioso: el cometa de 1577 "mostró las guerras de Flandres [y], la mudanza del reino de Portugal" ${ }^{33}$. Y no menos categórico fue Pedro Mejía, en 1619, cuando estableció una conexión, para él evidente, confirmada por "hartos" "testigos de vista y de autoridad", de que tras el cometa de 1577, "fue la infelice jornada de África y pérdida del rey don Sebastián" ${ }^{34}$.

Pero si bien se alaba el pronóstico certero, era necesario reinterpretarlo, pues la senda que se dibujaba era especialmente peligrosa. De ahí que la

30 Sigüenza, José de (2010). La fundación del monasterio de El Escorial. Valencia: CMC Editor, 82.

31 San Gerónimo, fray Juan de. Memorias ... cit., 234.

32 Santa Maria, Francisco (1644). Reforma de los Descalzos de Nuestra Señora del Carmen de la primitiva observancia. Madrid: Diego Díaz de la Carrera, tomo primero, 649. En 1642, Camargo y Salgado, Fernando (1642) La Iglesia militante. Madrid: Francisco Martínez, dice "Hiciéronse diversos juicios. El más cierto (como en semejantes cosas sucede) se hizo después de la desgraciada muerte del rey don Sebastián de Portugal", 311. De la Hera y de la Barra, Bartolomé Valentín (1584). Reportorio del mundo particular de las esferas del cielo y orbes elementales. Madrid: Guillermo Druy, fol. $65 \mathrm{r}-65 \mathrm{v}$, dice del cometa de 1577: "no surtieron sus efetos hasta agosto de 1578, con la muerte del rey don Sebastián y muerte y captiverios de tantos nobles portugueses en el reino de Marruecos".

33 Zamorano, Rodrigo (1594). Cronología reportorio de la razón de los tiempos. Sevilla: Rodrigo de Cabrera, 962. Texto que recoge también Cabrera de Córdoba, Luis, Filipe segundo... cit., 962.

34 Mexía, Pedro (1619) Discurso sobre los dos cometas que aparecieron el año pasado de 1618. Lisboa: Pedro Craesbeeck. Años más tarde el familiar del Santo Oficio, regidor y tesorero en Ciudad de los Reyes (Perú), consideraba, a partir de los comentarios de Bugufaro, que los cometas, por su forma y dirección, podían predecir los resultados de un ejército: "Y esto mesmo sucedió cuando el año de 1577 apareció aquel cometa en forma de bocina, que por ser instrumento bélico predijo guerras y muerte de reyes. Y por ser su movimiento de Poniente en Levante, pronosticó la pérdida del que fue a conquistar, como se experimentó en África con muerte de don Sebastián, rey de Portugal y rompimiento de su ejército". Figueroa, Juan (1660). Opúsculo de astrología en medicina y de los términos y partes de la astronomía. Lima, s.n. fol. 340v-341r. Opinión que también había sido recogida por el médico Núñez de Zamora, Antonio (1610). Liber de Cometis in quo demostratur Cometam anni 1604 fuisse in firmamento. $Y$ en romance el juicio de la máxima conjunction de Júpiter y Marte que le encendió. Salamanca, Antonia Ramírez, 62. 
mayoría contemplara el paso de los cometas de otra manera, más acorde, más cómoda intelectualmente, y no rupturista con la tradición clásica y con los dictados de la ortodoxia: el augurio dejaba de serlo para convertirse en señal, que solo podía descifrarse a posteriori. El mismo padre Sigüenza lo advierte: los cometas no eran sino señales del cielo con las cuales Dios nos avisa, pero "el hombre es tan atrevido, que ni aun el azote del cielo no teme, a costa de ejecutar sus intentos" ${ }^{\prime 3}$. Diego de Yepes, en sus Discursos de varia historia (1592), escribe en esta misma línea: Dios nos envía "maravillosas señales", para que "viéndolas nos apercibamos y prevengamos para aplacar la ira de su poderosa diestra”. Sebastián de Mesa, al narrar la jornada del rey portugués (1630), se muestra también categórico.

las amenazas del cielo se muestran por cosas grandes y para que corrijamos nuestra mala vida, más no para que creamos los juicios que sobre ellos se hicieren, aunque el mundo tiene por sabios a los cultos y críticos que creen que por la astrología que llaman judiciaria, se puede saber lo por venir y el estado florido de las repúblicas, trasiego de monarquías y mudanza de reinos. Es yerro notable, condenado por la Iglesia, santos y profetas $[. .$.$] El mismo peligro tiene$ quien creyere que los futuros contingentes se pueden saber por las suertes $y$ remitir a arbitrio tan ciego sus sucesos, pues ninguna suerte hay buena sino la que entra en las manos de Dios.

Entonces, si los cometas y otros fenómenos sobrenaturales eran reputados como avisos divinos, la voluntad de los príncipes ya no quedaba sujeta ineludiblemente a sus efectos. Es decir, el príncipe, que podía interpretar las señales, no quedaba determinado por los astros, era libre de actuar conforme a su criterio. De esta forma el libre albedrío quedaba por encima de un inapelable determinismo cósmico, dictador de la voluntad humana, y la responsabilidad del gobernante se sacudía así de las cadenas, pero también de las excusas.

En este sentido, las señales derivadas del paso del cometa de 1577 sirvieron como un elemento más que alimentó las críticas hacia la actitud del rey Don Sebastián en su empeño de llevar a cabo la empresa africana. No podía achacarse al cometa el fracaso de la expedición o la muerte del rey, sino que la responsabilidad debía recaer sobre el propio monarca, su soberbia e imprudencia, y sobre los aduladores que lo jalearon.

\footnotetext{
35 Sigüenza, José de. La fundación ... cit., 88.
} 
En efecto, Don Sebastian era un mozo "amigo de su parescer", que "sin consejo de nadie tomó esta empresa" ${ }^{36}$. Y los juicios sobre su personalidad temeraria, su escasa prudencia, o vanidad, se multiplicaron en las obras publicadas a finales del siglo XVI y durante buena parte del XVII ${ }^{37}$.

Para Bernardino Gómez Miedes, en un capítulo que insertó dentro de su Historia del rey Jaime I de Aragón (1584), todo fue fruto de la "miserable obstinación" del rey luso. El cometa había sido una señal, cuya

aparición no solo había anunciado a todos lo venidero, pero que al mesmo don Sebastián había dado tiempo para mirar muy bien lo que hacía y para que con el motivo y señales del cielo, consultase sobre la empresa y deliberase lo mejor. Porque no es de creer que los sabios y astrólogos de su reino se cegasen tan torpemente, que de un tan prodigioso cometa, cuya cola tiraba a África, para donde se encaminaba la armada, no hiciesen judiciario discurso y advirtiese al rey lo que del prodigio sentían, siquiera por excusar la ida de su persona. Mayormente no siendo esta guerra a favor de la religión cristiana, ni tan justificada que por ley alguna quedase don Sebastián obligado a seguir con su persona ${ }^{38}$.

Si bien los astrólogos atribuían al cometa el "infelicísimo suceso" de Don Sebastián en su "inconsiderada conquista", la responsabilidad, en palabras de Sánchez de Acre, en su Historia moral y filosófica (1590), solo podía ser suya:

Aunque los cometas, ni las estrellas y cuerpos superiores, no podían ser bastantes para necesitar a este rey mozo para emprender esta guerra, antes pudiera con la libertad de su albedrío domar la inclinación y apetito desenfrenado que por tentación del demonio se le había asentado en la fantasía. Pues aunque los cielos y sus influencias nos pueden inclinar, no nos pueden forzar, conforme a la sentencia muy celebrada de Ptolomeo, otra vez alegada: Vir sapiens dominabitur astris $^{39}$.

Herrera y Tordesillas si bien asociaba el cometa de 1577 a lo que Dios tenía dispuesto para el rey don Sebastián por sus "secretos juicios", no dejó de recoger los sucesivos consejos que recibió el joven monarca de no acudir

36 San Gerónimo, fray Juan de. Memorias... cit., 234.

37 Usunáriz, Jesús M. (2011). "Don Sebastián, Alcazarquivir, la unión de Coronas y el conflicto internacional en las crónicas y relaciones de sucesos de los siglos XVI y XVII”, in Colóquio Letras. Suplemento. Relaçoes hispano-portuguesas no século XVII. Septiembre (2011) 7-25.

38 Gómez Miedes, Bernardino. La historia del muy alto... cit., 279-280.

39 Sánchez de Acre, Pedro. Historia moral y filosófica ... cit., fol. 37v. 
en persona, de que no podía contar con el apoyo de su tío Felipe II: "pero con ninguna razón se movía don Sebastián y su perdición estaba dispuesta”" Muchos juicios y pareceres se hicieron, según el portugués Fernando de Goes Laurerio (1596) en su Breve suma y relación de los reyes de Portugal, del cometa avistado en 1577. Fueron muchos los que afirmaban que era "cierto anuncio de las calamidades y ruinas que en aquel reino después vinieron". Pero solo al rey se podía responsabilizar: "Más nada deso bastó para desviar de su propósito y jornada al desventurado rey don Sebastián, a quien el mismo cielo avisaba de la sentencia que contra él y los suyos tenía dada"41.

Los cometas, escribe Juan Vitrián en uno de los escolios a las Memorias de Philippe de Commines, eran divinos presagios, señales, "siendo este el lenguaje de Dios más usado sobrenaturalmente con los reyes (en demostración de ser el inmediato señor dellos)". Pero lo cierto era que tal divino presagio "suele hacer más osados a los reyes, presumiéndose cada uno que no amenaza a él sino a su contrario", que es lo que le ocurrió a Don Sebastián, que lejos de atemorizarle "le animó más a hacer su jornada de África" ${ }^{2}$.

Todavía a finales del siglo XVII, con motivo del paso del cometa de 1680, Luis Aldrete recordaba aquel de 1577: "y contra la opinión de todos porfió el rey D. Sebastián en pasar al África a su conquista”. Aviso del cometa, que fue "pronóstico de su muerte": "No hay cosa que no vocee el cielo"43.

40 Herrera, Antonio de (1591). Cinco libros de Antonio de Herrera de la Historia de Portugal y conquista de las islas de los Azores en los años de 1582 y 1583. Madrid: Pedro Madrigal, fol. 11r-11v.

${ }^{41}$ Laurerio, Fernando de Goes (1596). Breve suma y relación de las vidas y hechos de los reyes de Portogal. Mantua: Francisco Osana, 83-85.

42 Commines, Felipe de (1643). Las memorias de Felipe de Comines, señor de Argenton, de los hechos y empresas de Luis undécimo y Carlos octavo, reyes de Francia. Amberes: Ed. Juan Vitrián, Ivan Meursio, t. 2, 252-253.

43 Aldrete y Soto, Luis (1680). Discurso del cometa del año de 1680. Madrid: Lucas Antonio de Bedmar. Hay otros testimonios. En Santos, Manuel dos (1735) Historia Sebastica. Lisboa: Antonio Pedrozo Galram, en el cap. XXXI, se centra en hablar del cometa de 1577 y recoge unos versos que aparecieron en el palacio de Lisboa para convencer al rey de que desistiera en su empresa: "Pensamientos, ¿dónde vais?/ Donde vais , locos furiosos,/ ciegos con vuestros engaños/ donde tenéis ciertos los daños/y los remedios dudosos./ Empresa vana es aquella,/ que por nuestra fiera estrella/ o porque vos lo queréis/ si no desistirdes della/ catad que os despeñaréis", 387.

La comparación con los reyes españoles es también interesante. Miguel Martínez del Villar animaba en 1619 al rey Felipe II a la intervención y conquista de los reinos de Argel y Bujía, y establecía las diferencias entre los reyes y entre los cometas de 1577 y 1618: Pues a más que V.M. no imita a don Sebastián, rey mozo, y sin experiencia sino al rey católico, que la tuvo tan grande y tan felice, y por beneficio público de la cristiandad y no de los moros hace y emprende V.M. esta guerra. Aquel cometa fue contrario a Portugal y favorable a los moros, como lo escribieron todos los astrólogos de aquel tiempo. Este, por el contrario, es favorable a España y a la cristiandad y contrario a los africanos, de común opinión de todos cuantos escriben sobre él y ha salido en la conjunción magna, que es perjudicial a los moros, y no en la otra conjunción magna, que fue favorable a ellos". Martínez del Villar, Miguel (1619). Discurso acerca de la conquista de los reinos de Argel y Bujía, en que se trata de las 
Una imprudencia, la del rey, que debía ser compartida. Autores españoles la achacaban a los portugueses en su conjunto, bien por soberbia, bien por temor a la respuesta del rey. Según Herrera y Tordesillas, el cometa provocó miedo, pues era "señal de malos sucesos" y especialmente dañosa para los delicados cuerpos de los príncipes.

Pero los portugueses, interpretándolo en su favor, decían que aquella cometa hablaba con el rey y le decía: 'V. Alt. acometa'. Porque atenta a su gallarda inclinación, tenían más miedo de la ira del rey que de la del cielo ${ }^{44}$.

Testimonio que, tomado de Conestaggio ${ }^{45}$, fue utilizado por otros autores como Antonio San Román, para criticar a los portugueses ${ }^{46}$.

Esta apreciación crítica hacia la soberbia desventurada de Sebastián se trasladó también a otros ámbitos. Como nos recuerda Usandizaga, la imagen que Lope de Vega traslada del rey don Sebastián en El bautismo del príncipe de Marruecos, es la de un personaje trágico, obsesivo y arrogante que muere de forma heroica. En La jornada del rey don Sebastián en África, de Vélez de Guevara, don Sebastián es descrito como "un rey prodigioso", afectado por lo sobrenatural, valiente, impetuoso pero soberbio e imprudente "mal aconsejado" y "mozo mal advertido" que se glorifica con su muerte épica ${ }^{47}$. Vasco Mausino de Quevedo publicó en 1619 un Triunfo en honor a la entrada de Felipe III en Lisboa, en donde se recogían alusiones al caso del rey mozo Don Sebastián: su vano intento de imitar a Alejandro Magno, sus quimeras de grandeza, su soberbia, "en su persona solo confiando", a pesar de los apercibimientos cósmicos, del "anuncio triste del cometa":

razones que hay para emprenderla, respondiendo a las que se hacen en contrario. Barcelona: Sebastián de Cormellas, 2-3.

44 Herrera y Tordesillas, Antonio de. Segunda parte de la Historia General... cit., p. 109. Lo mismo recoge San Román, Antonio de. Jornada y muerte... cit., 42.

45 Conestaggio, Geronimo de Franchi. Historia de la unión ... cit., fol. 15v.

46 Vitrián en los escolios a Commines Felipe de. Memorias... cit., 252-253; San Román, Antonio de. Jornada y muerte... cit., 40-42. Faria y Sousa, Manuel, Europa portuguesa ... cit., 6-7 o en Faria y Sousa, Manuel de (1677). Epitome de las historias portuguesas. Bruselas: Francisco Foppens, 299; Baena Parada, Juan de, Epitome... cit., 124-125. El mismo Joao de Castro hace una autocrítica en su Discurso da vida... cit., fol. 30r-30v, pues después de describir los prodigios y en especial el cometa de 1577 como avisos divinos dice: "Emfim, não dando por nada \& triumphando en nos os pecados, determinou o Iustissimo çhamarnos a iuzio pera terra estranha diante de Barbaros, inimigos seus \& mahometanos".

47 Usandizaga Carulla, Guillem (2007). "Representar la derrota: Alcazarquivir en la escena áurea”, in Pedraza, F. B. y otros ed. (2007). Guerra y paz en la comedia española. Almagro: Universidad de Castilla-La Mancha, 35-47. 
Este Don Sebastián tan levantado por su desdicha fue de pensamiento que ha de Alejandro el espíritu imitado y las altas quimeras de su intento dominador del mundo se ha juzgado; sopla a su fuego el lisonjero viento bien pudiera el presagio no ser vano si igualara al valor consejo sano.

Pero sin electión, precipitando el orden militar, con poca gente por África entra osado conquistando, como si fuera un Jerjes propriamente, en su persona sola confiando prerrogativa de ánimo excelente. Más cuando el desengaño halló consigo, a las puertas estaba del castigo.

El cielo, condolido de su daño, con voces mudas advirtirse quiso, aunque jamás un resoluto engaño, conoscer supo saludable aviso.

Crinita cauda de un cometa extraño los aires amenaza de improviso.

Más el anuncio triste del cometa, su valor tuerce al pérfido Mahometa ${ }^{48}$.

En La gran comedia del rey don Sebastián, de Francisco de Villegas, don Sebastián se muestra de nuevo soberbio, despreciativo hacia los augurios del cometa que había aterrado a los lisboetas:

Prior de Crato Dadme vuestra mano.

Sebastián. Tío,

¿Qué hay de nuevo?

Prior de Crato Gran señor

lo que esta noche ha pasado,

de que está el pueblo alterado,

lleno de espanto y temor.

Sebastián ¿De qué pudo proceder?

48 Quevedo,Vasco Mausino de (1619). Triunfo del monarca Filipo tercero, en la felicísima entrada de Lisboa. Lisboa: Jorge Rodrigues, fol. $55 \mathrm{v}$. 
Prior de Crato Justa causa le obligó.

Una cometa se vio,

señor, al anochecer,

la color al cobre igual,

y de desigual grandeza,

al África la cabeza,

y la cola a Portugal.

Parece que lo que dura

está abrasando la tierra,

hambre, tempestad y guerra,

amenaza y asegura,

ha causado tanto espanto

que está Lisboa afligida.

Guarde Dios, señor, la vida

de vuestra majestad, cuanto

este reino ha menester.

Sebastián. ¿ ¿África es la amenazada?

Pues en ella aquesta espada

tinta en sangre se ha de ver ${ }^{49}$.

El castigo que siguió, la muerte de D. Sebastián, no fue sino un escarmiento, por no saber interpretar, en definitiva, los designios divinos:

Prevalecerá con esto la verdad -escribía el padre San Román- para que escarmienten los príncipes de la tierra a no gobernar por sola su cabeza negocio de tanta importancia, donde el daño es inmenso, y conozcan los hombres cómo son los juicios de Dios maravillosos.

Un castigo divino que tuvo consecuencias: para unos, excelentes y providenciales, como la unión de las Coronas:

Débense dar muchas gracias a Dios por el buen paradero que tuvo una calamidad tan grande, pues teniendo un Dios, una Fe, un Bautismo, una Iglesia y una naturaleza, ha sido él servido que también estemos todos a la sombra de un rey, que hace con su potencia formidable la nación española en todo el mundo" ${ }^{50}$.

49 Villegas, Francisco de (1663). "La gran comedia del rey don Sebastián", in Palacio y Villegas, Domingo ed. (1663). Parte diez y nueve de comedias nuevas y escogidas de los mejores ingenios de España. Madrid: Pablo de Val, fol. 63v-64r.

so San Román, Antonio de. Jornada y muerte... cit., Prólogo 
Y, para otros, desastrosas, como estimaba el padre Vieira, porque los portugueses no habían sabido interpretar "la voz de Dios" con las señales del cielo de 1577 y 1580 . A la postre, el reino "quedó cautivo y sujeto a un rey extraño, y no por menos de sesenta años enteros, en los cuales, con tantas quiebras y pérdidas de la difunta monarquía fue pagando lentamente en los huesos de ella toda la deuda de los castigos, a que los dos cometas fatales, la tenían condenada" ${ }^{51}$.

\section{Conclusión. La crítica política y la legitimación de la conquista de Portugal}

El cometa de 1577 no fue solo una anécdota. Fue un fenómeno de una gran repercusión científica en toda Europa. Alimentó la superstición y con su devenir a través de los cielos iluminados por estrellas de plata, fue asociado al destino de un rey y de un reino. Fue un recurso literario, a la manera de la tradición clásica, en donde los cometas servían de referencia sobrenatural para los hechos históricos. Pero, el pronóstico o, si se prefiere, el signo, fue utilizado como un factor de legitimación política ${ }^{52}$. Los errores de un rey imprudente, augurados por fenómenos celestes y eventos extraordinarios, servían para dar más peso, más autoridad a los hechos posteriores. Si para los autores portugueses del siglo XVII, especialmente tras 1640, la muerte del rey Sebastián, anunciada por el cometa, fue el vaticinio de la pérdida de la independencia, "de la pérdida de Portugal", para muchos de los españoles testigos directos o indirectos de los hechos, sirvió para dar apoyo, frente a sus críticos, a la toma de decisiones que acabaron con la conquista de Portugal por las tropas encabezadas por un anciano duque de Alba y de la que don Sebastián, por su inmadura osadía, era el máximo responsable.

51 Vieira, Antonio (1712). Sermones varios. Madrid: Nicolás Rodríguez, 328. Ni tampoco la voz de los hombres, pues fueron muchos (personas doctas, astrólogos e incluso Roma), como recuerda el portugues Soares en su Memorial, los que advirtieron que el cometa anunció la perdición del rey Soares, Pero Roĩz (1953). Memorial. Ed. M. Lopes de Almeida. Coimbra: Acta Universitatis Conimbrigensis, 90-91.

52 Redondo, Augustin (2000). Introduction in Redondo, Augustin (ed.). La prophétie comme arme de guerre des pouvoirs (Xve-XVIIe siècles). Paris: Presses de la Sorbonne Nouvelle, 5-7. 


\section{Bibliografia}

ALDRETE Y SOTO, Luis (1680). Discurso del cometa del año de 1680. Madrid: Lucas Antonio de Bedmar.

BAENA PARADA, Juan de (1692). Epitome de la vida y hechos de don Sebastián. Madrid: Antonio González de Reyes.

CABRERA DE CÓRDOBA, Luis (1619). Filipe segundo rey de España. Madrid: Luis Sánchez.

CAROLINO, Luís Miguel (2004). "O Ensino de Filosofia Natural nas Universidades Portuguesas: ideias e percursos académicos, 1550-1650”, in Estudos em Homenagem a Luís António de Oliveira Ramos. Porto: Faculdade de Letras da Universidade do Porto, vol 1, 371-378.

CAROLINO, Luís Miguel; Camenietzki, Carlos Ziller (2006). “Tokens of the future: comets, astrology and politics in early modern Portugal”, Cronos, 9, 33-57.

CASTRO, Joao de (1602). Discurso da vida do sempre bemvindo et apparecido rey Dom Sebastiam. Paris: Martin Verac.

COMMINES, Felipe de (1643). Las memorias de Felipe de Comines, señor de Argenton, de los hechos y empresas de Luis undécimo y Carlos octavo, reyes de Francia. Amberes: Ed. Juan Vitrián, Ivan Meursio.

CONESTAGGIO, Geronimo de Franchi (1610). Historia de la unión del reino de Portugal a la corona de Castilla. Barcelona: Sebastián de Cormellas.

DE LA HERA Y DE LA BARRA, Bartolomé Valentín (1584). Reportorio del mundo particular de las esferas del cielo y orbes elementales. Madrid: Guillermo Druy.

DÍAZ, Nicolás (1599). Tratado del juicio final, en el cual se hallarán muchas cosas curiosas y provechosas para la salud de las almas y recreación de los que las leyeren. Madrid: Luis Sánchez.

FARIA Y SOUSA, Manuel (1680). Europa portuguesa. Segunda edición. t. 3. Lisboa: Antonio Craesbeeck.

FARIA Y SOUSA, Manuel de (1677). Epitome de las historias portuguesas. Bruselas: Francisco Foppens.

FERNÁNDEZ RAJO, Francisco (1578). De Cometis et prodigiosis eorum portentis, libri quatuor. Madrid: Guillelmus Dreuy.

FIGUEROA, Juan (1660). Opúsculo de astrología en medicina y de los términos y partes de la astronomía. Lima, s.n..

FRAY JUAN DE LA VICTORIA, Libro de los cometas, fenómenos y portentos, BNE, ms. 880.

GÓMEZ CRESPO, Félix and Esteban Piñeiro, Mariano and Jalón Calvo Mauricio (1993). “Astrología en el siglo XVI. Un nuevo tratado sobre el cometa de 1577”, in Actes de les II Trobades d'Història de la Ciència i de la Tècnica: (Peníscola, 5-8 desembre 1992). Barcelona: Institut d'Estudis Catalans, 263-272.

GÓMEZ MIEDES, Bernardino (1584). La historia del muy alto e invencible rey don Jaime de Aragón, primero de este nombre, llamado el conquistador. Valencia: Pedro de Huete. 
GOODMAN, David C. (1988). Power and Penury: Government, Technology and Science in Philip II's Spain. Cambridge: Cambridge University Press.

GRANADA, M. A. ed. (2012). Novas y cometas entre 1572 y 1618. Revolución comológica y renovación política y religiosa. Barcelona: Universidad de Barcelona

HELLMAN, C. Doris (1944). The Comet of 1577: Its Place in the History of Astronomy. New York: AMS Press.

HERRERA Y TORDESILlAS, Antonio de (1591). Cinco libros de Antonio de Herrera de la Historia de Portugal y conquista de las islas de los Azores en los años de 1582 y 1583. Madrid: Pedro Madrigal.

HERRERA Y TORDESILLAS, Antonio de (1601). Segunda parte de la Historia General del Mundo de XI años del tiempo del señor rey don Felipe II, el prudente, desde el año de MDLXXV hasta el de MDLXXXV. Madrid: Pedro Madrigal.

HOROSCO Y COVARRUBIAS, Juan de (1588). Tratado dela verdadera y falsa profecía. Segovia: Juan de la Cuesta.

ILLESCAS, Gonzalo (1652). Historia Pontifical y Católica. Madrid: Gabriel de León.

IRIARTE, Joaquín (1996). La canción del cometa de 1577: un médico renaciente, Francisco Sánchez, en lucha con la astrología. Una página de la física aristotélica que se desploma con estrépito. Una página de las Cortes de Madrid y Lisboa completamente inédita, Bilbao: Universidad de Deusto.

LAURERIO, Fernando de Goes (1596). Breve suma y relación de las vidas y hechos de los reyes de Portogal. Mantua: Francisco Osana.

MACÍAS VILLALOBOS, Cristóbal (2006). "Los cometas en el mundo antiguo: entre la ciencia y la superstición”, Veleia: Revista de prehistoria, historia antigua, arqueología y filología clásicas, 23.

MACKAY, Ruth (2012). The Baker Who Pretended to Be King of Portugal. Chicago: The University of Chicago Press.

MAGNIER, Grace (2010). Pedro de Valencia and the Catholic Apologists of the Expulsion of the Moriscos. Visions of Christianity and Kingship. Leiden: Brill.

MARIANA, Juan de (1685) Historia general de España. Madrid: Francisco Martínez.

MARTÍNEZ DEL VILLAR, Miguel (1619). Discurso acerca de la conquista de los reinos de Argel y Bujía, en que se trata de las razones que hay para emprenderla, respondiendo a las que se hacen en contrario. Barcelona: Sebastián de Cormellas.

MESA, Sebastián de (1630). Jornada de África por el rey don Sebastián y unión del reino de Portugal a la corona de Castilla. Barcelona: Pedro Lacaballería.

MEXÍA, Pedro (1619) Discurso sobre los dos cometas que aparecieron el año pasado de 1618. Lisboa: Pedro Craesbeeck.

MICÓN, José (1578). Diario del juicio del grande cometa que nuevamente nos ha aparecido. Barcelona: Jaime Sendrat.

MUÑOZ, Jerónimo (1578). Suma del prognóstico del cometa y de la eclipse de la luna. Valencia: Joan Navarro. 
NAVARRO BROTONS, Víctor (2012). "Las novedades celestes en España entre 1572 y 1618”, in Granada, M. A. ed. (2012). Novas y cometas entre 1572 y 1618. Revolución cosmológica y renovación política y religiosa. Barcelona: Universidad de Barcelona, 15-41.

NOUTHUYS, Etabita van (1988). The Age of Two Faced Janus. The Comets of 1577 and 1618 and the Decline of the Aristotelian World View in the Netherlands. Leiden, Brill.

NÚÑEZ DE ZAMORA, Antonio (1610). Liber de Cometis in quo demostratur Cometam anni 1604 fuisse in firmamento. Y en romance el juicio de la máxima conjunction de Júpiter y Marte que le encendió. Salamanca, Antonia Ramírez.

PALACIO Y VILLEGAS, Domingo ed. (1663). Parte diez y nueve de comedias nuevas y escogidas de los mejores ingenios de España. Madrid: Pablo de Val.

QUEVEDO,Vasco Mausino de (1619). Triunfo del monarca Filipo tercero, en la felicísima entrada de Lisboa. Lisboa: Jorge Rodrigues.

REDONDO, Augustin (2000). Introduction in Redondo, Augustin (ed.). La prophétie comme arme de guerre des pouvoirs (Xve-XVIIe siècles). Paris: Presses de la Sorbonne Nouvelle.

SALAZAR DE MENDOZA, Pedro (1770). Monarquía de España. Madrid: Joaquín Ibarra.

SAN GERÓNIMO, fray Juan de (1845). “Memorias” in Colección de documentos inéditos para la historia de España. t. 7, Madrid: Viuda de Calero.

SAN ROMÁN, Antonio de (1603). Jornada y muerte del rey don Sebastián de Portugal, sacada de las obras de Franchi, ciudadano de Génova. Valladolid, Juan Íñiguez de Lequerica.

SÁNCHEZ DE ACRE, Pedro (1590). Historia moral y filosófica en que se tratan las vidas de doce filósofos y príncipes antiguos. Toledo: Viuda de Juan de la Plaza.

SANTA MARIA, Francisco (1644). Reforma de los Descalzos de Nuestra Señora del Carmen de la primitiva observancia. Madrid: Diego Díaz de la Carrera.

SANTOS, Ilda dos (2000). "Le temps d'un roi. Prophéties et conquêtes à l'époque de Sébastien du Portugal (1554-1578), in Redondo, A. ed. (2000). La prophétie comme arme de guerre des pouvoirs (XVe-XVIIe siècles). Paris: Presses de la Sorbonne Nouvelle, 109-122.

SANTOS, Manuel dos (1735) Historia Sebastica. Lisboa: Antonio Pedrozo Galram.

SEYNER, Antonio (1644). Historia del levantamiento de Portugal. Zaragoza: Pedro Lanaja y Lamarca.

SIGÜENZA, José de (2010). La fundación del monasterio de El Escorial. Valencia: CMC Editor.

SOARES, Pero Roĩz (1953). Memorial. Ed. M. Lopes de Almeida. Coimbra: Acta Universitatis Conimbrigensis.

TRABULSE, Elías (1974). Ciencia y religión en el siglo XVII. México: El Colegio de México.

USANDIZAGA CARULLA, Guillem (2007). "Representar la derrota: Alcazarquivir en la escena áurea”, in Pedraza, F. B. y otros ed. (2007). Guerra y paz en la comedia española. Almagro: Universidad de Castilla-La Mancha, 35-47.

USUNÁRIZ, Jesús M. (2011). “Don Sebastián, Alcazarquivir, la unión de Coronas y el conflicto internacional en las crónicas y relaciones de sucesos de los siglos XVI y XVII”, 
in Colóquio Letras. Suplemento. Relaçoes hispano-portuguesas no século XVII. Septiembre (2011) 7-25.

VARELA, Javier (1990). La muerte del rey. El ceremonial funerario de la monarquía española 1500-1885. Madrid: Turner.

VIEIRA, Antonio (1712). Sermones varios. Madrid: Nicolás Rodríguez

YEPES, Diego de (1592). Discursos de varia historia. Toledo: Pedro Rodríguez.

ZAMORANO, Rodrigo (1594). Cronología reportorio de la razón de los tiempos. Sevilla: Rodrigo de Cabrera. 



\title{
Aristóteles en el Banquillo: el prólogo al Libro del Nuevo Cometa de Jerónimo Muñoz

\author{
Aristotle in the dock: the prologue to Jeronimo \\ Muñoz' Libro del Nuevo Cometa
}

\author{
FELIX K.E. SCHMELZER \\ Universidad de los Andes - Chile \\ fschmelzer@uandes.cl
}

Texto recebido em / Text submitted on: 21.09.2015

Texto aprovado em / Text approved on: 26.10.2015

Resumen: El prólogo-epístola al Libro del nuevo cometa (1573) de Jerónimo Muñoz es el primer rechazo decisivo del paradigma aristotélico en España. Este rechazo es sobre todo un procedimiento retórico: el astrónomo y hebraísta valenciano hace uso de elaborados recursos argumentativos y estilísticos que crean la imagen de un 'Aristóteles en el banquillo' que, finalmente, es declarado culpable de la ignorancia en temas de astronomía, argumentación a base de la cual Muñoz puede propagar su propia nueva cosmovisión. Un análisis de los pasajes decisivos de esta refutatio histórica no solo revela el papel central de la retórica en el discurso científico del Siglo de Oro español, sino también la importancia que tiene en el proceso de un cambio de paradigma de la visión científica del mundo.

Palabras clave: Muñoz, Libro del nuevo cometa, Aristóteles en España, retórica y ciencias, cambio de paradigma.

Abstract: The epistolary prologue to Jeronimo Muñoz' Libro del nuevo cometa (1573) is the first resolute refutation of the Aristotelian paradigm in Spain. It is primarily a rhetorical procedure: the Valencian astronomer and hebraist makes use of elaborated argumentative and stylistic strategies that create the image of an 'Aristotle in the dock' who, at the end of the discourse, is declared guilty of ignorance with respect to astronomic subjects. In that way, Muñoz creates an argumentative basis for propagating his new cosmology. An analysis of the central passages of this historic refutatio not only reveals the importance of rhetoric in the scientific discourse of the Spanish golden age, but also its central role in the process of a paradigm shift in the scientific world view.

Keywords: Muñoz, Libro del nuevo cometa, Aristotle in Spain, Rhetoric and Science, Paradigm shift. 
El prólogo-epístola al Libro del nuevo cometa de Jerónimo Muñoz ${ }^{1}$ es un documento científico-histórico de gran interés porque aquí se rechaza por primera vez de manera resolutiva la cosmología aristotélica en España, un paso importante hacia una nueva visión del universo. La génesis del libro se debe a un fenómeno celestial que preocupaba por aquel entonces a la comunidad científica, una supernova (en términos modernos) que apareció en el cielo en 1572 y fue visible en toda Europa hasta 1574, cambiando de color y de intensidad lumínica. Este "cometa" daba pie a distintas especulaciones astronómicas y cosmológicas y, además, inspiraba a numerosos poetas. No se sabía exactamente de qué tipo de fenómeno se trataba y había dudas respecto a si pertenecía a la zona sublunar o a la zona supralunar². Siendo el más reconocido astrónomo en España, la corte de Felipe II había pedido a Muñoz que observara este fenómeno y aclarara las dudas.

La respuesta de Muñoz se publicó como breve tratado en 1573, el Libro del nuevo cometa, donde el valenciano desarrolla una nueva teoría, a un alto precio. Su teoría es capaz de explicar científicamente la supernova, suponiendo que se trata de un fenómeno celestial, lo que significaría que los cielos (es decir, la zona supralunar) no son inmutables, sino que conocen "corrupción" y cambio. Siendo la inmutabilidad de los cielos una idea nuclear de la cosmología aristotélica, la teoría de Muñoz pone en duda todo un sistema filosófico válido durante casi dos milenios. La conflictividad es inevitable y, por ello, el autor hace uso en el prólogo de varios recursos argumentativos y estilísticos para socavar la credibilidad de Aristóteles, un primer paso necesario para poder implantar su propia nueva cosmovisión. En este momento, Muñoz no ha comprobado su teoría todavía, sino la propaga, con el objetivo de que el lector se comprometa con la perspectiva deseada. Es decir que se trata de un procedimiento retórico más que científico; y la elocuencia de Muñoz es, de hecho, llamativa. En lo que sigue, esbozaré brevemente la estrategia de esta refutatio histórica, centrándome en los primeros párrafos

1 Jerónimo Muñoz (1520-1591) fue catedrático de hebreo y matemáticas en la Universidad de Valencia a partir de 1565. En 1578 se trasladó a la Universidad de Salamanca, donde ocupó la cátedra de astrología. Entre sus obras cuentan un tratado titulado Institutiones arithmeticae ad percipiendam Astrologiam (1566) y un Alphabetum hebraicum cum ratione legendi cum punctis (1585), así como diversos manuscritos. Puede que una parte considerable de su obra quede por descubrir todavía. Su trabajo más importante desde la perspectiva científico-histórica es, sin duda, el Libro del nuevo cometa. Para más informaciones, ver Navarro Brotóns 1981: 14-84.

2 La distinción del universo en las regiones sublunar (desde la tierra hasta la esfera del fuego) y supralunar (desde la luna hasta la última esfera del 'primer motor inmóvil') forma la base de las teorías astronómicas del siglo XVI. Es de proveniencia aristotélica (ver, sobre todo, Acerca del cielo y Acerca de la generación y la corrupción). 
del texto. Espero poder mostrar que la retórica forma una parte integral del discurso científico en el Siglo de Oro español.

Para el análisis del texto es útil tener en cuenta la función general del género del prólogo. Ante todo, se trata de un discurso que sirve para persuadir a los lectores de que lean el libro, por lo que su contenido debe ser recomendado como importante, útil, curioso, etc. Es obvio que aquí la retórica entra en el juego, y cuanto más que cualquier autor culto del siglo XVI gozaba de una amplia formación retórica ${ }^{3}$. En el caso de Muñoz, el valor del libro está en una nueva teoría cosmológica cuya aceptación depende en gran medida de la disposición que tengan los lectores de renunciar a Aristóteles ${ }^{4}$. Por ello, la refutación del filósofo es nuclear, y el astrónomo y hebraísta valenciano aplica una sofisticada estrategia de argumentación para conseguirla. En este contexto, no sorprende que el presente prólogo revela una cercanía al genus iudicale de la retórica clásica ${ }^{5}$. Uno se puede imaginar una sala de audiencia con Muñoz como acusador, Aristóteles como acusado, y los lectores formando los jueces y el público. Veamos, con esta idea auxiliar en mente, como empieza el texto:

Así por cartas desa corte de vuestra majestad como de otras muchas partes tengo entendido el deseo grande que muchos tienen de saber este nuevo cuerpo que aparece en el cielo, si es estrella o si es cometa, y que hay diferentes opiniones acerca desto y dudan del lugar donde esta estrella está cuanto a la longitud del zodíaco ${ }^{6}$, que es en qué signo está de los que hace el sol, haciendo los equinoctios ${ }^{7}$ y los solsticios ${ }^{8}$ (de los cuales cuatro puntos nace el zodíaco de

3 Comp. Kristeller 1961: 19. Con vistas a la importancia de la retórica en el sistema educativo español en particular, ver Briesemeister 1993.

4 Más precisamente, la teoría no encaja en el paradigma cosmológico contemporáneo, y el lector solo la aceptará en la medida en que vea la necesidad de renunciar a este paradigma, que es esencialmente aristotélico.

5 La retórica clásica, con sus géneros tradicionales (genus iudicale, genus deliberativum, genus demonstrativum, a los que se añaden el ars praedicandi y el ars dictaminis a partir de la Edad Media), es todavía decisiva en la España del siglo XVI.

6 Explico los términos técnicos en la medida posible en su significado científico-histórico según las definiciones citadas en el Diccionario de la Ciencia y de la Técnica del Renacimiento (DICTER): "Consideran los astrólogos, en el octavo cielo, un círculo mayor a quien llaman “zodíaco”, el cual tiene de anchura doce grados, en medio del cual está imaginada una línea que llaman eclíptica, que parte y deja los seis grados hacia él un polo, y los otros seis hacia el otro, la cual distancia se llama latitud" (Anónimo, Repertorio de tiempos, 1554, fol. XXIIr-XXIIv).

7 "Llámase equinoccial porque cuando el Sol pasa por la equinoccial, que son dos veces en cada año, la una en el comienzo de Aries, que es a once de marzo, la otra en el comienzo de Libra, que es a catorce de setiembre, los días e las noches son iguales, así que equinoccio quiere decir igualador de la noche y del día” (Fernández de Enciso, Suma de geografía, 1530, fol. IVv, en DICTER).

8 "Y llámanse solsticios porque en el mes de diciembre y de junio, cuando ellos acontecen, en el sol no hace notable mudanza en el lugar donde nace y se pone, ni en el número de las horas y partes del 
los astrólogos, según el cual en las efemérides ${ }^{9}$, que los moros y caldeos llaman «almanach», se ponen y asientan los lugares de los planetas). Más dudan si esta estrella está en el aire o en el cuerpo que llaman cielo, más piden la significación de este cuerpo nuevo.

Aunque el autor todavía no va 'al grano', este pasaje inicial del prólogo es importante para establecer su credibilidad y generar simpatía por su persona en los lectores ${ }^{10}$. Dirigiéndose directamente a Felipe II, que tenía la fama de ser un gran conocedor y amante de las ciencias matemáticas ${ }^{11} y$, junto a él, a los científicos de su corte, Muñoz esboza la situación de partida, sin posicionarse todavía: ha aparecido un nuevo cuerpo celestial y no se sabe si está situado en la esfera del aire, es decir, en la zona sublunar, o en la zona supralunar. Sus palabras ya indican la necesidad indispensable de clarificar las cosas ("deseo grande de saber", "diferentes opiniones", “dudan”... ). El uso de varios términos técnicos y definiciones pone en evidencia que se trata de un público culto y sirve, desde la perspectiva retórica, además para acentuar desde el inicio los conocimientos astronómicos del autor. El tono es pertinente y aparentemente objetivo, pero con cálculo ${ }^{12}$. Se podría decir que Muñoz se presenta a sí mismo en estas primeras líneas como un hombre culto y conocedor de la materia cuyo objetivo es acabar con las dudas y encontrar la verdad en el nombre del bien común.

A partir de ahí, el astrónomo denuncia ante los lectores el supuesto 'culpable' de la crisis científica en torno a la aparición de la nova, Aristóteles:

Las causas de dudar toman las de la fe y crédito que dan a Aristótil, el cual con agudas palabras les ha dado a entender que el cielo es de su naturaleza incorruptible, que es quinta esencia ${ }^{13}$, que no está compuesto, no digo de materia y forma -que esto es de necios peripatéticos-, pero de elementos, y contra Demócrito y Anaxágoras, no quiere que hayan salido las estrellas y el cielo del

día" (Nebrija, Tabla de días y horas, 1517, fol. IVr, en DICTER).

9 "Y a estos días están reguladas y constituidas todas las tablas de los movimientos, como son todas las efemérides y Tablas alfonsíes, y, finalmente, todas las tablas astronómicas" (Sacrobosco, Esfera, trad. de Jerónimo de Chaves, 1545, fol. LXVv, en DICTER).

10 Se trata de un procedimiento que la retórica clásica suele llamar captatio benevolentiae.

11 No se debe al azar que la Real Academia de Matemáticas se fundara bajo su reinado, en 1582.

12 De acuerdo con el genus humile que se aconseja para la estrategia retórica del docere.

13 La formulación "quinta esencia" (pémpte ousía) se refiere a un quinto elemento del cual están compuesto las estrellas y planetas. Al contrario de los cuatro elementos terrenales, que se mezclan el uno con el otro y por tanto, son corruptibles, este elemento aparece solo en forma pura. Como destaca Vigo (2007: 83), la noción de una quinta esencia está ya inherente a la cosmología aristotélica, pero proviene en su forma precisa de la tradición posterior. 
caos, que Moisén llamó «tohu va bohu», sino que siempre fueron y serán, porque son de su naturaleza incorruptibles, coeternas con la primera causa. De suerte que, según Aristótil, los cielos y sus inteligencias son tan eternas causas como la primera, y sobre ellas no tiene más poder que de primer movedor, el cual, como esté en la suprema convexa haz del mundo, dando la vuelta al cielo más arriba, hace que las inteligencias muevan, y con él entiendan en mover los orbes inferiores. Cuánto mejor dice Platón en el Timeo, que propone a Dios hablando con los cielos y estrellas y las inteligencias: "dii deorum, quorum opifex ego, et pater sum, haec attendite: quae a me facta sunt, me ita volente indissolubilia sunt. Omne siquidem, quod vinctum est, solui potest: sed mali est, quod pulchre compositum est beneque; se habet, velle dissolvere. Qua propter, quia generati estis, immortales quidem et indissolubiles omnino non estis, nec tamen unquam dissoluemini, nec mortis fatum subitis. Nam voluntas mea, maius praestantiusque; vobis est vinculum ad vitae custodiam, quam nexus illi, quibus estis tunc, cum gignebamini, colligati” ${ }^{14}$.

Los procedimientos argumentativos y estilísticos que deben socavar la credibilidad y la autoridad del filósofo griego son evidentes desde el principio. Ya en la primera frase, la formulación "agudas palabras" aproxima a Aristóteles a la figura de un sofista, capaz de convencer a la gente por su habilidad retórica, pero sin estar interesado en la verdad. La validez de sus teorías es, asimismo, puesta en duda por designar a sus seguidores como "necios peripatéticos”, expresión que se esconde en un comentario aparentemente marginal. Además, la descripción del modelo aristotélico es simplificadora y enfoca la falsa -según Muñoz-suposición de la eternidad e incorruptibilidad de los cielos.

Ahora bien, el primer paso importante para refutar la cosmología aristotélica consiste en demostrar que la incorruptibilidad y eternidad de los cielos contradice la idea de la creación del mundo. Se trata de un contrargumento poderoso, dado que se basa en el concepto del Dios creador de la Biblia. Si los cielos siempre han estado ahí, eso significaría, según Muñoz, que el poder de Dios se limitara a mover las esferas de un universo que él no ha creado (precisamente porque siempre estaba ahí). Por tanto, Dios, según la filosofía aris-

14 "Dioses, hijos de dioses, obras de las que yo soy artífice y padre, que, por mí engendradas, son indisolubles, mientras yo no lo quiera. Todo lo que está anudado puede ser desatado; no obstante, es propio de un malvado querer deshacer la hermosura de un vínculo armónico, que se encuentra en perfecto estado; por lo cual, si bien toda vez que habéis llegado a la existencia, no sois inmortales ni indisolubles en absoluto, no obstante, no os disolveréis ni tendréis parte en el destino de la muerte, pues habéis obtenido en suerte mi voluntad, un vínculo aún más fuerte y poderoso que aquéllos con los que os ligasteis al llegar a la existencia" (Timeo, 4la-b). 
totélica, sería solo el 'primer motor' ${ }^{15}$, pero no el creador. Lo que Muñoz no sabe o, más probable, oculta conscientemente, es que este conflicto aparente entre la imagen aristotélica del mundo y la Biblia ya había sido solucionado por Tomás de Aquino, que diferencia entre los niveles físico y metafísico para dar a entender que el concepto aristotélico se aplica al primero, mientras que la concepción bíblica de la creación se aplica al segundo nivel ${ }^{16}$.

Muñoz refuerza su argumentación con cuatro testigos, procedentes de la tradición filosófica griega y de la tradición bíblica judeo-cristiana: Anaxágoras, Demócrito, Moisés (como autor del Génesis) y Platón. Se trata de nombres acreditados, y su supuesta unión construye un contrapeso considerable a la autoridad científica de Aristóteles, que en el siglo XVI parecía irrefutable todavía. De hecho, todos ellos pueden verse como representantes de un modelo que proclama o, al menos, admite la idea de un Dios creador que, según Muñoz, es negada por el concepto aristotélico. Eso se revela a través de una breve revisión de sus ideas cosmológicas. En cuanto a Anaxágoras y Demócrito (supuesto discípulo del primero), ambos pensaron que la creación del mundo se debe a la actividad de una mente que actúa sobre un estado primordial e indiferenciado de la materia (el kháos de la filosofía griega), lo que queda patente a través de varios textos, entre ellos, una Historia de la filosofía atribuida a Galeno, que fue muy popular durante la época ${ }^{17}$. También son significativas en este contexto las siguientes palabras que Diógenes Laercio atribuye a Anaxágoras: "Todas las cosas estaban juntas; luego vino la Inteligencia y las ordenó" ${ }^{18}$. Un lector culto del siglo XVI probablemente tendría presente estas fuentes.

Moisés, obviamente, le sirve a Muñoz en primer lugar para basar su argumentación también en la autoridad bíblica. La expresión tohu va bohu, que puede traducirse como «desolado y vacío», indica en la Biblia (Génesis 1, 1-2)

15 Aristóteles intenta comprobar la existencia de un 'primer motor', a su vez inmóvil, en el libro XII, 6 de la Metafísica. En el marco de una teoría del movimiento, el concepto de 'primer motor' tiene que ser entendido causalmente, y no temporalmente, dado que el universo, según Aristóteles, es eterno.

16 Quiero dar las gracias al profesor Alejandro Vigo por esta sugerencia.

17 Comp. Galeno (De philosophica historia, capítulo 25): "Anaxagoram potius audiamus, qui divinam mentem asserit, res omnes a primordiis mundi inter se confusas distinxisse, atque ita res omnes procreasse; uel Anaximandrum, qui stellas coelestes deos arbitrabatur; aut Democritum, qui mentem ígneo circularique corpore utentem, hoc est mundi animam deum ese affirmabat”.

18 Vidas y opiniones de los filósofos ilustres, II, 6. Algo similar es comunicado por Plutarco, quien afirma que Anaxágoras «fue el primero en ponerle al universo como principio de organización no el azar y la necesidad, sino una inteligencia pura y sin mezcla que en el conjunto de todo lo demás mezclado separa las homeomerías» (Vidas paralelas, II, Pericles, 4). 
la etapa anterior a la creación de la luz, etapa de confusión y desorden ${ }^{19}$ : "En el principio creó Dios los cielos y la tierra. Cuando la tierra estaba informe y vacía [tohu va bohu], con oscuridad sobre la faz del abismo [tehom]”. En rigor, el término hebreo tohu va bohu y el término griego kháos no son equivalentes, como Muñoz indica en el párrafo citado, porque el primero deja lugar a la idea de una creación ex nihilo (que acentúa la omnipotencia divina), mientras que el segundo presupone la existencia de una masa primordial sobre la que Dios actúa como una especie de escultor. Una vez más se revela que la argumentación no es necesariamente científica, es decir, objetiva. Supongo que Muñoz (un destacado hebraísta) acepta una posible contradicción en el nivel lógico-racional porque la acumulación de testigos es más importante en esta etapa del discurso.

A Platón, finalmente, por la larga cita, se le otorga el estatus de 'testigo principal'. Él es, sin duda, el filósofo con mayor autoridad que se puede enfrentar a Aristóteles en aquella época. Mientras muchos pensadores del Renacimiento intentaron armonizar las ideas de ambos, Muñoz los opone aquí polémicamente. La mención del Timeo se explica, entre otros factores, por la gran popularidad de esta obra en el siglo XVI (fue muy difundida la traducción latina de Marsilio Ficcino que cita Muñoz en el párrafo ${ }^{20}$ ). En este su libro cosmológico principal, Platón describe que el universo ha sido creado por un demiurgo matemático cuya omnipotencia equivale, en cierto sentido, a la del Dios bíblico, como se ve en la cita: el creador platónico es el "artífice y padre" de los "dioses" [es decir, los cielos], que, al contrario del modelo aristotélico, no son "inmortales ni indisolubles en absoluto" ("immortales quidem et indissolubiles omnino non estis") y se someten a la voluntad de su creador ${ }^{21}$.

En esta fase del discurso, con los presocráticos, el mito de la creación bíblico y Platón en su contra, la posición de Aristóteles ya se ha debilitado considerablemente. Ahora Muñoz lanza el segundo 'golpe' argumentativo:

Mas les ha dado a entender los cometas hacerse en la suprema región del aire, y no en el cielo, como quiere Demócrito, y Anaxágoras, filósofo y matemático gravísimo, cuyas opiniones cuanto a los cometas no entendió Aristótil, por no

19 La expresión también se emplea en Isaías $(34,11)$ y Jeremías $(4,23)$ en este significado, pero precedido de animación y hermosura.

20 En Platonis dialogi latine. Juxta interpretationem Ficini, XI. La cita se encuentra en la página 248.

21 Desde la perspectiva científico-histórica, la oposición del Timeo a la cosmología aristotélica es muy interesante porque representa la imposición paulatina de una imagen matemática del cosmos (que tendrá su punto culminante en la frase famosa de Galilei según la cual 'el libro de la naturaleza está escrita en caracteres matemáticos') en una etapa inicial de la "revolución científica". 
ser astrónomo ni tener principios para entender la doctrina de los caldeos y egipcios, los cuales, con subtiles demonstraciones de geometría y de aritmética y de perspectiva, se subieron a la contemplación de los cielos y a entender el gobierno que tienen ellos sobre las cosas corporales de acá bajo. Y, perseverando Aristótil en su opinión que los cielos son eternos, ha porfiado estar los cometas en el aire, porque veía que si los recibía dentro del cuerpo del cielo, como ellos sean fuegos o llamas, era necesario conceder los cielos de su naturaleza ser corruptibles según algunas partes [...]. Esto ha causado que, viendo, aun por razones naturales sacadas de las propiedades deste cometa, que él está en el cielo y tiene naturaleza o parentesco con las estrellas fijas, no han podido entender lo que con los ojos pudieran ver.

El texto deviene más concreto ahora. Muñoz hace referencias explícitas a la teoría aristotélica de los cometas, que está estrechamente vinculada a la cosmología del filósofo. Las descripciones remiten en particular a los capítulos 3-8 del primer libro de los Meteorológicos, donde Aristóteles explica como meteorológicos algunos fenómenos que, desde la perspectiva de hoy, serían astrofísicos es decir, como fenómenos que tienen lugar dentro de la atmósfera. En el marco de su teoría, los cometas se forman en la parte más exterior de la esfera del aire, que limita con la esfera del fuego, siendo ambas esferas pertenecientes a la zona sublunar. Esta idea es opuesta a Anaxágoras y Demócrito, y esta segunda mención de los dos filósofos presocráticos no es al azar porque el mismo Aristóteles refiere en los Meteorológicos las opiniones de ambos -que conciben los cometas como cuerpos celestiales de la zona supralunar $^{22}$ - para refutarlas después. Es obvio que Muñoz procede exactamente al revés.

También en este párrafo es llamativo como se caracteriza a Aristóteles: el filósofo es presentado como un 'cabezota' que perseveraba en su falsa opinión porque, y este es el punto culminante de la acusación, no entendía las matemáticas. A esa caracterización se opone la de Anaxágoras, a su vez designado como «filósofo y matemático gravísimo». De tal manera, Muñoz niega a Aristóteles la capacidad y competencia para tratar adecuadamente la cuestión de los cometas porque, como señala, solo él que entienda "la doctrina de los caldeos y egipcios"23 (que se añaden a la lista de testimonios en

22 Ver Meteorológicos, I, 6.

23 La formulación presupone un supuesto origen de la astronomía y astrología en Egipto y/o Caldea, como creía la mayoría de los autores antiguos y medievales. Ver, por ejemplo, Herodoto, Historia, II, 4; Diodoro de Sicilia, Biblioteca histórica, II, 31,7-9; Jámblico, Sobre los misterios egipcios, IX, 4; san Isidoro, Etimologías, III, 25. La mención de estos países también sirve para relacionar la astronomía con la idea de un saber secreto y mágico. 
contra del acusado) y las "subtiles demonstraciones de geometría y de aritmética y de perspectiva" tiene voz en ese asunto -una sofisticada estrategia argumentativa-.

En la última frase de la cita, Muñoz remite otra vez a la fe ciega con la que la comunidad científica de aquella época ("ellos") seguía a Aristóteles, a pesar de estar en contra de las "razones naturales" y de lo que "con los ojos pudieran ver" (las formulaciones se refieren a la observaciones empíricas de las posiciones de la supernova). Ahora, finalmente, ha construido una sólida base para el argumento principal con el que pretende derrocar definitivamente el paradigma aristotélico y proclamar su propia teoría:

Por tanto, habiéndome hecho Dios merced de darme ingenio libre, bien inclinado y aparejado para entender cualquier facultad, viendo la flaqueza de las razones de Aristótil, con que quiere probar ser el cielo eterno, y habiendo observado con instrumentos las mudanzas que hay en el cielo, como son la irregularidad de los movimientos y revoluciones particulares de cada uno dellos, y viendo que las revoluciones dellos no son iguales, y que los lugares de las estrellas se han mudado desigualmente, y que las máximas declinaciones del sol (que pensaban ser inmudables) se han mudado, y que los apogeos y perigeos de planetas (que son los puntos de la máxima y mínima distancia dellos hasta la tierra), de tiempo de Ptolomeo hasta agora, se han mudado en más de 26 grados ( $y$ eran tenidos por inmudables), viendo que los años se hacen menores de lo que solían ser, como por instrumentos se puede ver, he entendido que es falso lo que dice, que es común opinión de todas las gentes que nunca ha habido en el cielo mudanza alguna, por lo cual los hace eternos; y, pues sé que hay en ellos mudanza y en ellos se encienden los cometas, he sido forzado, por razones naturales y demonstraciones geométricas, conceder que hay en el cielo corrupción e incendios.

Con decisión y en nombre de la verdad científica demostrable, el autor se involucra a sí mismo como oponente a Aristóteles; una posición en la que, después de la mención de varios testigos, ya no se encuentra solo. El tono de las acusaciones se hace más estridente aun que en los apartados anteriores, los argumentos aristotélicos son designados como "flaqueza" y "común opinión”. El alto grado de elaboración retórica del discurso se revela por el hecho de que está marcado en esta fase decisiva por una amplificación semántica y sintáctica: Muñoz enumera varias observaciones empíricas ${ }^{24}$ que

24 Las observaciones mencionadas aquí son muy instructivas desde la perspectiva científico-histórica porque ejemplifican la derrota paulatina de la imagen aristotélico-ptolemaica del universo; un cambio de paradigma es ya inminente. A lo largo de los siglos, con datos de observación cada vez 
contradicen a Aristóteles y las enlaza mediante una sintaxis paralela y repetitiva (“viendo...”, “y viendo que...”, “y que...," “y que...”). Además, repite y modifica términos y palabras clave como "irregularidad", "mudanza", "desigualmente", etc., que asimismo contradicen la cosmología aristotélica, en la que las revoluciones de los planetas se realizan de manera regular y uniforme. De este modo, el acusado, que ya se encuentra en una posición muy difícil, es aplastado por así decir, con argumentos en su contra.

El punto culminante de la argumentación de Muñoz constituye la afirmación de haber sido forzado "por razones naturales y demonstraciones geométricas". En el contexto de lo anteriormente dicho, eso quiere decir que, junto a las autoridades mencionadas ya, el astrónomo se apoya también en la autoridad de las observaciones empíricas (con instrumentos), incluyendo las deducciones que siguen de ellas, y en la autoridad de la demostración matemática. Este argumento, que ya ha sido preparado por la mención de las matemáticas en el apartado anterior, implica que Muñoz, al contrario que Aristóteles, no insiste en una mera «opinión», sino que ha desarrollado su teoría de acuerdo con los postulados científicos de la Modernidad. Con estas palabras llamativas, que apuntan hacía un nuevo espíritu de la época que todavía está por venir, termina la refutación de la cosmología aristotélica ${ }^{25}$. A partir de ahí, Muñoz instaurará su propia teoría de los cometas.

En suma, la estrategia argumentativa aplicada por Muñoz revela una posición media entre una retórica humanista y una retórica científica (en el sentido moderno de la palabra). Es decir, por un lado se basa en la autoridad de pensadores antiguos y bíblicos, por el otro, como ya dicho, en la autoridad de la observación empírica y la demostración matemática. Parece que la primera tiene una ligera preponderancia todavía, aunque la segunda forma el clímax de la refutatio. En este sentido, el texto da testimonio de una época de transición.

más precisos, la imagen del cosmos se hacía cada vez más desuniforme e irregular. Para mantener el postulado de las revoluciones circulares de los planetas (que Kepler sustituirá por la noción de órbitas elípticas), los astrónomos del siglo xvi tenían que añadir numerosas revoluciones en forma de epiciclos (pequeños círculos sobre el círculo, que Muñoz llama aquí «revoluciones particulares»). En este contexto, un argumento principal de los pioneros del heliocentrismo fue que la geometría del cielo se hace mucho más regular con el sol en el centro. Ver, en este contexto, Kuhn 1985; también Schmelzer 2011.

25 Muñoz añade, en el apartado siguiente, dos ejemplos que igualmente contradicen a Aristóteles, pero la función en este caso es más bien elocutiva que argumentativa: "Por lo cual los estoicos pensaron que el mundo es corruptible, y que a la fin se hará transmutación del mundo por fuego, según escribe Galeno (De philosophica historia, capítulo 29). Beda, anglosajón, siente las aguas que están sobre el cielo haberlas puesto encima Dios para templar el fuego de las estrellas y cometas". 
Quiero dejar en claro que no ha sido mi intención disminuir la indudable importancia astronómica de la obra de $\mathrm{Muñoz}^{26}$, sino mostrar que la retórica desempeña un papel importante en el discurso científico del Siglo de Oro español, sobre todo cuando se trata de cuestiones de principios que no son definitivamente demostrables (como la pregunta de si el universo es eterno o ha sido creado, por ejemplo) y, por ello, pertenecen más bien al área de lo opinable ${ }^{27}$. Como este breve análisis ha mostrado, la argumentación en favor de una determinada opinión, aunque sea científica, es necesariamente una argumentación en perspectiva, que, además, amplia los aspectos en su favor, mientras que oculta aquellos que están en su contra.

En un contexto más general, este prólogo ejemplifica también que la retórica forma parte del proceso de un cambio de paradigma en la visión (científica) del mundo ${ }^{28}$, cuando un concepto científico dominante es puesto paulatinamente en duda, mientras que el que irá a reemplazarlo cristaliza de manera progresiva. Esta disciplina es una herramienta necesaria, no solo para proclamar un nuevo paradigma y derrotar al anterior, sino, además, para preparar la sociedad en general y la comunidad científica en particular al cambio inminente. Como ya he destacado, el papel de Muñoz es pionero en este contexto $^{29}$.

\section{Bibliografía}

ARISTÓTELES (1987). Acerca de la generación y la corrupción / Tratados breves de historia natural. Madrid: Gredos.

ARISTÓTELES (1996). Acerca del cielo / Meteorológicos. Madrid: Gredos.

26 Debido a sus observaciones precisas del fenómeno, el Libro del nuevo cometa es considerado hasta hoy día el mejor estudio realizado en España, y uno de los mejores de Europa, sobre la supernova de 1572. Varios astrónomos contemporáneos, entre ellos Tycho Brahe, se refieren a la obra del valenciano.

27 En principio, este papel de la retórica en el discurso científico no ha cambiado, pero los científicos del Siglo de Oro estaban más conscientes de ello que los científicos de nuestra época.

28 Como se sabe, un tal cambio se está ejecutando en toda Europa en el ámbito cosmológico a lo largo de los siglos XVI y XVII. La cosmovisión geocéntrica, de proveniencia aristotélico-ptolemaica, es reemplazada paulatinamente por la cosmovisión heliocéntrica y en ese proceso los astrónomos ponen en duda cada vez más la autoridad de Aristóteles.

29 Sería interesante, por tanto, comparar su prólogo con otros escritos de la época que asimismo pretenden introducir nuevos paradigmas científicos. Se puede pensar, por ejemplo, en el proemio que encabeza De revolutionibus orbium coelestium, donde Copérnico, al igual que Muñoz, se refiere a la filosofía presocrática para propagar su teoría (Copérnico remite al Filolao, filósofo pitagórico, cuya idea de un "fuego central" utiliza para proclamar la teoría heliocentrista). 
ARISTÓTELES (1994). Metafísica. Madrid: Gredos.

BRIESEMEISTER, Dietrich (1993). "Rhetorik und Humanismus in Spanien”, en Renaissance Rhetorik, ed. Heinrich F. Plett. Berlin: De Gruyter, 92-106.

Diccionario de la Ciencia y de la Técnica del Renacimiento (DICTER). Salamanca: Ediciones Universidad [dicter.usal.es].

DIODORO DE SICILIA (2001). Biblioteca histórica. Libros I-III. Madrid: Gredos.

DIÓGENES LAERCIO (2010). Vidas y opiniones de los filósofos ilustres, Zamora: Lucina.

GALENO (1543). De philosophica historia liber unus, Coloniae: Johannes Aquensis.

HERODOTO (1977). Historia. Madrid: Gredos.

ISIDORO DE SEVILLA (2004). Etimologías. Madrid: Biblioteca de Autores Cristianos.

JÁMBLICO (1997). Sobre Los Misterios Egipcios. Madrid: Gredos.

KRISTELLER, Paul Oskar (1961). Renaissance thought. The classic, scholastic, and humanist strains. New York: Harper.

KUHN, Thomas S. (1985). The Copernican Revolution. New York: MJF.

MUÑOZ, Jerónimo (1573). "A la sacra, católica, real Majestad del Rey don Felipe II. El maestro Gerónimo Muñoz, catedrático de hebreo y matemáticas en la Universidad de Valencia”, en Libro del nuevo cometa. Valencia: Pedro de Huete, fols. Irr-Vr.

NAVARRO BROTÓNS, Victor (1981). “Introducción”, en Muñoz, Jerónimo. Libro del nuevo cometa, Valencia, Pedro de Huete, 1573 / Littera ad Bartholomaeum Reisacherum, 1574 / Summa del prognostico del cometa, Valencia, Juan Navarro, 1578. Valencia: Cultural, 14-84.

PLATÓN (1826). Platonis dialogi latine. Juxta interpretationem Ficini, Londoni: Priestley.

PLATÓN (2012). Timeo. Madrid: Consejo Superior de Investigaciones Científicas.

PLUTARCO (2010). Vidas Paralelas. Madrid: Gredos.

SCHMELZER, Felix K.E. (2011), “«In medio ómnium residet sol»”: Die Idee des Schönen im Heliozentrismus”, en Repräsentationsformen von Wissen, ed. Annika Nickenig. München: Meidenbauer, 29-45.

VIGO, Alejandro G. (2007). Aristoteles. Una introducción. Santiago de Chile: Instituto de Estudios de la Sociedad, 2007. 


\title{
Diplomacia e sociabilidade intelectual na viagem a Itália de D. Francisco Manuel de Melo
}

\section{Diplomacy and intellectual sociability in the italian journey of D. Francisco Manuel de Melo}

\author{
Paulo Silva Pereira \\ Universidade de Coimbra - FLUC/ CLP \\ psilvapereira@sapo.pt
}

Texto recebido em / Text submitted on: 15.09.2015

Texto aprovado em / Text approved on: 21.10.2015

Resumo: Este estudo parte de uma circunstância específica, a viagem de D. Francisco Manuel de Melo a Itália na década de 60 do século XVII, para abordar o cruzamento entre política, diplomacia, atividade cultural e convivialidade discreta, em especial durante o tempo da sua permanência na cidade de Roma. Permite ainda lançar um olhar sobre a configuração das redes de sociabilidade intelectual que se consolidavam, de modo transversal, por essa altura no espaço europeu e de que faziam parte também agentes culturais de origem portuguesa.

Palavras-chave: Barroco; viagens a Roma; missões diplomáticas; sociabilidade intelectual.

Abstract: This study based on the circumstances of the travel of D. Francisco Manuel de Melo to Italy in the 60 's of the seventeenth century aims to analyse the intersection between politics, diplomacy, cultural activity and discreet conviviality, especially during the time of his stay in Rome. It also allows to cast a glance at the configuration of intellectual sociability networks that were flourishing by then in Europe and with the participation of many portuguese cultural agents.

Keywords: Baroque; journeys to Rome; diplomatic missions; intelectual sociability.

1. Quando, no derradeiro capítulo da sua Relação do novo caminho da Índia para Portugal, o Padre Manuel Godinho evoca o encontro que manteve com D. Francisco Manuel de Melo na cidade de Marselha, numa altura em que este se encontrava em trânsito a caminho de Itália para tratar do casamento de Afonso VI e para tentar resolver, junto da cúria papal, as questões dos bispados vagos e dos cristãos-novos, fica bem patente a viva impressão que lhe causou: 
Fui logo visitado do senhor D. Francisco Manuel, o qual, com nome suposto de Monsieur Chevalier de S. Clément, passava a Roma, recomendado a todos os príncipes e repúblicas amigas, por cartas patentes dos senhores reis de Inglaterra e França. Não é crível o gosto que me causou a visita deste fidalgo; só o pode considerar quem souber estimar suas inestimáveis prendas, quem tiver gozado de sua admirável conversação, quem for lido em seus engenhosos livros, quem de seu singular juízo formar aquele conceito que dele tem feito o mundo todo, quem de seu primor estiver obrigado como o eu estou, porque todas estas cousas juntas foram os motivos de meu gosto naquela visita. (Godinho, 1974: 253-254)

Tanto quanto se pode depreender das suas palavras, essa convivência momentânea permitiu certificar, quando não reforçar ainda mais, todo o mérito que se lhe atribuía (ainda que, neste caso, a coberto de um avatar - o misterioso Chevalier de Saint Clément - criado especificamente para preservar o caráter sigiloso da missão ${ }^{1}$ ). Embora não fosse caso único na Península Ibérica (como fica bem patente até pela estratégia de emulação que, em certas ocasiões, se pretende instituir com a figura de Quevedo), o seu percurso biográfico, marcado tanto por momentos de glória, como pelo desencanto e pelo sofrimento, despertava a curiosidade dos contemporâneos (para utilizar expressão neutra que não favorece os seus mais íntimos admiradores ou seus misteriosos inimigos).

Pelos ecos que até nós chegaram, é de supor que, à medida que o tempo avançava, mais nítidos se tornavam os contornos de uma figura que, a vários títulos, se podia considerar excecional. É sabido que a imagem que temos de uma personalidade histórica não é neutra nem inocente, mas de Manuel de Melo se pode dizer que contribuiu ativamente (pelo pensamento e pela ação) para compor esse perfil de homem de eleição, capaz de atuar com eficácia em vários palcos do mundo. Por outro lado, soube constituir-se a si próprio como exemplo vivo das virtudes, do saber teórico e prático necessário para enfrentar as exigências de um mundo hostil, do gosto requintado e da sociabilidade que tanto elogiou. Até mesmo quando deixa ressoar a voz do

1 Vale a pena lembrar que Melo de forma a contornar eventuais acusações de oportunismo político, vindas sobretudo do lado espanhol, resolve então estampar a sua Guerra de Cataluña (1645) sob o pseudónimo de Clemente Libertino, explicando detalhadamente o sentido deste "nome fingido" que figura no frontispício de "um livro tão verdadeiro" (p. 93): "a não ter o nome que tenho, esse houvera de ser o meu nome, sendo Clemente o santo tutelar de meu nascimento, o qual estimo pelo mais afortunado horóscopo e ascendente. Libertino, porque já sabeis que era, entre os Romanos, o nome dos filhos de escravos libertos. Assim, aludindo à liberdade que já gozava minha pátria, fiz dela brasão e apelido. Se em tudo errei, bem pode ser culpa da eleição, que pertence ao juízo, não do propósito, que é filho da vontade" (Melo, 1970: 95). 
desengano, vem ao de cima a sua condição existencial, o seu estatuto como homem de letras e o seu papel como 'tratadista' ao serviço da aristocracia que, não raro, se confrontava com os reveses da Fortuna ${ }^{2}$.

Não por acaso, a viagem diplomática que realiza, entre 1663 e 1665, por Londres, Paris e Roma, só seria possível (como de facto foi) em virtude de uma mudança significativa operada no seio da corte portuguesa em 1662: a subida ao trono de $\mathrm{D}$. Afonso VI, que pôs termo à regência de $\mathrm{D}$. Luísa de Gusmão, e a escolha do conde de Castelo Melhor, seu amigo e parente, para chefiar o governo, na medida em que permitiu inverter o ciclo de descrédito e de perseguições de que vinha sendo vítima pelo menos desde o reinado de $\mathrm{D}$. João IV. Infelizmente pouco pôde beneficiar de tão auspicioso clima político, pois viria a falecer em 1666.

A passagem de Manuel de Melo pela Itália pode ser equacionada em vários planos, suscetíveis, contudo, de se relacionarem entre si: pela sua intrínseca relevância, destacaremos o plano político-diplomático e o plano das relações culturais. Ao mesmo tempo, deve notar-se desde já que no primeiro caso o balanço não pode ser estabelecido de modo unívoco, um pouco à semelhança do que acontece com tantos outros legados ou agentes diplomáticos do Portugal Restaurado que viajaram pelas cortes europeias, obtendo assinaláveis êxitos nuns casos, e não poucas derrotas e frustrações noutros: ele é necessariamente afetado tanto pelo clima de vincada crispação e de confronto bélico com Espanha (de 1641 às campanhas finais de 1663 e 1665, ainda que de forma intermitente) como pelo intenso quadro de rivalidade entre potências europeias em luta pela hegemonia ${ }^{3}$. Vale a pena recordar que, além dos debates sobre o início das negociações de paz entre as monarquias ibéricas, os conselheiros de Afonso VI discutiam a possibilidade de se estabelecer uma forte aliança com outro país europeu. Assim, da mesma forma que o casamento de Catarina de Bragança e Carlos II havia permitido o reforço da ligação com os ingleses, a união de Afonso VI e do infante $\mathrm{D}$. Pedro com princesas estrangeiras garantiria o apoio formal de mais um aliado contra os castelhanos.

Como era hábito em semelhantes ocasiões, foram preparadas Instruções secretas, uma assinada pelo rei e outra pelo Secretário de Estado, António de Sousa de Macedo (ambas de 27 de outubro de 1662), em que de forma

\footnotetext{
2 Para uma abordagem mais desenvolvida da relação entre o perfil de D. Francisco Manuel de Melo e o modelo do cortesão prudente e discreto na cultura barroca peninsular, cf. Pereira, 2007.

3 Sobre as missões secretas e negociações levadas a cabo por D. Francisco ao serviço da coroa portuguesa, pode o leitor encontrar informações de grande utilidade no ensaio de Ana M. H. Leal de Faria (2011).
} 
pormenorizada se descrevem as razões que estão na base da sua missão e se estipula o que lhe compete fazer, tirando partido da sua "prudência, juízo e capacidade" 4 . São documentos preciosos, a par de outros de índole semelhante, para uma reconstituição mais fidedigna do contexto que antecede (e rodeia) o processo de negociações junto da cúria pontifícia. É-lhe garantida, no entanto, alguma margem de autonomia, uma vez que se faz depender a concretização prática das ações da "disposição e acerto" que as circunstâncias exigissem, até porque a demora com que se processava a troca epistolar nessa altura e o ritmo a que, por vezes, evoluíam os acontecimentos políticos no terreno desaconselhavam um cumprimento estrito, apenas e só, do que estava inicialmente disposto nesses documentos que havia recebido. Atendendo à delicadeza da missão que seria necessário empreender em Roma, compreende-se o grau de meticulosa preparação que ora faz circunscrever o âmbito do relacionamento de D. Francisco Manuel de Melo com membros de ordens religiosas que se encontrassem na região por aqueles dias, por se entender que poderia ter efeitos danosos ${ }^{5}$, ora procura limitar a exibição de signos distintivos que pudessem indiciar a ligação à Coroa: "Também não levareis por hora mais número de criados que até cinco ou seis, por não dar a entender que ides como ministro meu, dispondo de tal maneira o trato de vossa pessoa, casa e família que não causeis ciúme, nem também desprezo, porque na estimação dos amigos e emulação dos contrários possais proceder em meu serviço sem o menor desar nem risco em vossa pessoa, e com toda a autoridade e quietação, procurando porém fazê-lo de tal sorte que por nenhum acontecimento se alcance sois ali mandado por mim, enquanto não convier dá-lo assi a entender" ${ }^{6}$. Se, noutras ocasiões, se procurava investir, quantas vezes a despeito de critérios de racionalidade orçamental, na entrada pública de um representante do poder régio na corte em que era acreditado, porque tal contribuía para a afirmação simbólica do prestígio do monarca, neste caso o investimento é de sentido inverso, procurando garantir decência mínima, mas sem levantar suspeitas quanto à condição

4 Prestage, 1914: 512 (documento n. ${ }^{\circ} 85$ ). Em todos os passos transcritos atualizámos a grafia, mas procurámos manter, sempre que possível, a pontuação do original.

5 Por reforçar o sentido grave e muito melindroso dos assuntos de Estado a que Manuel de Melo deveria atender durante a sua permanência na cidade, transcrevemos o passo em que se faz menção dessa estratégia: "procurareis passar dali [Génova e Liorne] a Roma, não levando em vossa companhia religioso algum, nem em seu hábito, nem no alheio, pelo grande descrédito de que são naquela Corte, além das inquietações e perturbações que a sua ida causa nas religiões destes reinos, a cujos prelados tenho mandado ordenar procurem evitar estas jornadas, tendo com eles, enquanto ali assistirdes, a menor comunicação que for possível”, Prestage, 1914: 513 (documento n. ${ }^{\circ} 85$ ).

6 Prestage, 1914: 513. 
do enviado. Manifestações de apertada cautela são recorrentes ao longo do texto destas Instruções, mas é de sublinhar ainda assim o lote de recomendações que são feitas a propósito da visita ao Cardeal Protetor de Portugal, Virginio Orsini, sobre quem recaíam suspeitas de quebra de fidelidade aos interesses do nosso reino:

procurareis vesitar o Cardeal como um fidalgo português, que favorecido de meus ministros ides a Roma a negócios particulares vossos, dando-lhe a minha primeira carta que para ele levais, e introduzindo por este modo a vossa negociação, procurareis alcançar dele com destreza as primeiras notícias, não mostrando (ainda no caso de achardes dele ruins indícios) desconfianças, nem fazendo demonstração por obra ou por palavra de que conheça terdes conhecido o seu ânimo. (Prestage, 1914: 514)

Acontece, porém, que a viagem só viria a ter lugar no ano seguinte (1663), por motivos políticos, acabando por prevalecer uma estratégia algo diferente, que aparece gizada numa outra Instrução, agora de 18 de Janeiro de 1663, implicando uma passagem prévia pela Inglaterra e pela França. É intenção do monarca fazer com que Melo parta tão rapidamente quanto possível em direção a Roma (ainda e sempre o fim último da missão diplomática), mas não sem antes fazer um "rodeio" (é o termo que consta do documento original) por Inglaterra, para se encontrar com o Marquês de Sande, Francisco de Melo e Torres, embaixador português na corte inglesa, uma vez que Catarina de Bragança tinha vindo a realizar uma ou outra diligência junto da cúria pontifícia em favor da causa portuguesa, através de um seu colaborador, Sir Richard Belling.

2. Corria o mês de setembro de 1663 quando Melo desembarcou em Génova, ficando aí a residir por dois meses. Dirigiu-se depois a Parma e chegou, por fim, a Roma em dezembro desse mesmo ano, onde viria a permanecer até novembro de 1664. A mais circunstanciada descrição que nos deixou sobre essa experiência de viagem (incluindo também a referência à passagem pelos territórios inglês e francês) encontra-se numa carta em verso dirigida ao seu amigo Francisco Correa de Lacerda e mais tarde incluída no volume das Obras Métricas (Fístula de Urania, epístola V). Presume-se que tenha sido redigida em Parma na segunda metade de 1663, pelo que infelizmente não chega a tocar no período da sua permanência em Roma. Os últimos tercetos da composição (que procura acompanhar o fio cronológico dos aconteci- 
mentos desde a partida de Lisboa) são consagrados, com efeito, à evocação da sua chegada àquela região italiana:

Subo; y apenas la vista le descubre, cuando del Po la decantada orilla de verdes lutos de álamos se encubre.

La armada, despidiéndome, cuadrilla que a las insidias ya del odio, o el caso, real mano ha mandado prevenilla,

con ánimo sincero y manso paso arribo en esta corte, donde escribo su exceso liberal con modo escaso. (Melo, 2006: II, 961)

Muito embora o autor tenha manifestado a intenção, noutros momentos, de reduzir a escrito os sucessos e desventuras da jornada italiana (basta ter em conta, a título de exemplo, a promessa que deixa ao seu amigo neste poema: "para mejor tiempo su alabanza / ya desde agora, grato, le apercebo"), não chegou a fazê-lo, até porque algum tempo depois de chegar a Lisboa viria a falecer.

Que esta missão internacional era especialmente delicada, podendo até comportar risco de vida, é algo que se comprova na série de Instruções que recebeu, pela insistência na preservação do segredo, a coberto do disfarce de negócios particulares que justificariam a sua ida a Roma, e pela exortação a que não se deixasse intimidar pelas ameaças dos castelhanos. Sirva como confirmação deste último ponto, pela sua decisiva relevância, um passo da Instrução de 27 de outubro de 1662, ainda há pouco referida, até pelo cuidado posto na eleição do homem que viesse a desempenhar a missão:

No meio das satisfações e sumições de que usardes para vos introduzir em Roma, o fareis também de palavras de grande sentimento e mistério, sem vos perturbarem nem intimidarem as cavilações e ameaças dos Castelhanos, pois com esta mesma razão cometo a demonstração deste negócio (no caso que seja necessário fazê-la) a ũa tal pessoa como vós, e da vossa profissão, e não a pessoa eclesiástica. (Prestage, 1914: 517)

Correspondia-se, durante todo este período, diretamente ora com o rei, ora com Castelo Melhor, o que permite confirmar a natureza muito sensível da missão e o seu estatuto hierarquicamente superior em relação a outros 
legados. Uma parte significativa dessas cartas seguia escrita em código ("em cifra”, como então se dizia), pois havia sempre o risco de ser intercetada e inspecionada ${ }^{7}$. Melo tinha uma aguda consciência da vulnerabilidade dos canais de comunicação e por isso não surpreende que possamos encontrar na sua correspondência indicações práticas quanto ao modo de proceder, como se comprova em carta enviada a 25 de agosto de 1664: "podeis mandar ou remeter qualquer aviso extraordinário em cifra, dirigindo-o por via dos Padres da Companhia e que venha aqui ao Padre Donelli... pela língua francesa em o Colégio Romano, porque com esta direcção virá às minhas mãos segura qualquer carta".

Fruto do seu continuado empenho, da sua destreza em conduzir negociações políticas e das boas relações que mantinha com eclesiásticos influentes, viria finalmente a concretizar-se a tão desejada audiência com o Papa Alexandre VII. O entusiasmo com que descreve, na correspondência dirigida ao Conde de Castelo Melhor, esse singular momento é bem a prova de que não faltaria sensibilidade, ao mais alto nível da Cúria, para perceber e aceitar a legitimidade da causa portuguesa, não fora a pressão vinda de Castela e o delicado equilíbrio geo-estratégico entre potências europeias:

hoje, dia do Senhor Rei S. Luís [25 de agosto de 1664], tive audiência de Sua Santidade de três quartos de hora. Está bem com os Melos e me disse muitas cousas dos dous irmãos, D. Francisco e D. Álvaro. Discorreu-se variamente e no fim o apertei quanto um homem podia a um Papa; ficámos bem e ele me mandou, como quem pode, que a tudo o de negócio tivesse segredo inviolável. Bem podereis vós entender que me não mandaria calar o que nos está mal. (Melo, 1981: 518)

Muito embora se assumisse, no contexto do Ocidente cristão, como cidade santa e destino de peregrinações religiosas, Roma era também um centro de poder temporal, com tudo quanto isso implica em matéria de cargos, congregações, colégios, tribunais e embaixadas. Ora, o retrato que Manuel de Melo oferece da corte pontifícia do seu tempo, numa carta dirigida "ao Geral

\footnotetext{
Do ritual próprio de uma missão secreta como seria sempre a de Manuel de Melo ou de qualquer outro representante português numa cúria pontifícia ainda muito sensível à pressão castelhana dá conta um dos parágrafos da Instrução de 62: "De tudo o que passardes nestes negócios me ireis avisando por todas as vias seguras, com toda a clareza, e sem respeito a pessoas particulares, para que meus ministros, fundados nas notícias que derdes, me possam aconselhar o mais conveniente; e assim para estes avisos, como para os que haveis de fazer aos ministros e embaixadores que tenho fora do Reino, a quem mando escrever vos ajudem e assistam nesta negociação, se vos entregarão cifras na Secretaria de Estado." (Prestage, 1914: 517).

8 Melo, 1981: 519.
} 
de certa Religião, sobre negócios tocantes ao bom governo dela”, não deixa de ser, a vários títulos, demolidor:

Esta Corte tem seus modos de negociação assaz lamentados e lamentáveis; e não há virtude tão robusta que facilmente resista às tentações que, ou por enojo ou por exemplo, oferece o demónio aos bons, apresentando-lhe o triunfo dos maus. $[\ldots]$

Os Prelados que assistem nesta Cúria, perdidos da piedade sua, obrigados do rogo e respeitosos à intercessão, julgam que é perdão a mais competente mezinha; com o qual aquele que parece vai curado sai de sua presença mais perigoso. Nas informações distantes há seguro risco; e os que dirigem e dão movimento às partes e membros deste corpo julgam que satisfazem sua obrigação, governando-os da própria maneira que de sua cabeça são governados. (Melo, 1981: 516)

Poder-se-á argumentar que este juízo tão severo é mera consequência da frustração de expetativas de um agente diplomático e da causa que representa, mas não deixa de refletir, na sua desarmante crueza, o instável equilíbrio entre as leis divinas e os interesses dos homens.

Boa parte do material atualmente disponível sobre este período da vida de D. Francisco ainda se fica a dever à pesquisa levada a cabo por Edgar Prestage em arquivos e bibliotecas, no final do século XIX e início do século XX. Do lote de documentos que então recolheu, em especial no Archivo General de Simancas, constam várias cartas (ou talvez com mais propriedade valesse a pena dizer: relatórios) sobre as diligências feitas ${ }^{9}$. Cumpre assinalar, por outro lado, que as redes de informação e de espionagem ligadas à coroa castelhana estiveram muito ativas durante estes anos, recolhendo, analisando e remetendo dados para o rei Filipe IV. Comandavam essa poderosa engrenagem, neste caso específico, o Cardeal de Aragón e o seu irmão, D. Pedro de Aragón, ambos sempre com extrema atenção a tudo quanto dissesse respeito ao enviado de Afonso VI: "Por lo que se ha ofrecido estos días en lo tocante a Don Francisco Manuel, he procurado se le observe con todo cuidado adonde entra y con quien comunica, y así mismo con que Cardenales ha tratado antes, si ha regalado a alguno, a quien y con qué"10. É muito curioso observar

\footnotetext{
9 O estudioso lembra as dificuldades por que passou para poder reconstituir o tempo de permanência de Melo em Roma, muito por causa da impossibilidade de se aceder à correspondência com a Cúria Romana em todo o segmento que vai de 1663 a 1668, lançando mão em contrapartida da correspondência trocada entre o Marquês de Sande e o Conde de Castelo Melhor, por um lado, e do Cardeal de Aragón e do seu irmão com Filipe IV, por outro (Prestage, 1914: 363).

10 Prestage, 1914: 554 (documento n. ${ }^{\circ} 110$ ).
} 
o detalhe com que se descreve não só as circunstâncias das visitas ou pontuais encontros com destacados membros da Cúria Romana, como o teor e a quantidade de presentes oferecidos. Ainda quando tentava iludir a vigilância exercida sobre si, recorrendo a estratégias mais insinuantes como o disfarce, de pouco adiantava, pois sempre alguém lá estava para controlar: "Supe que había ido vestido de clérigo a Castelo a solicitar la audiencia, respondéosle con exclusiva, con que se volvió, no habiendo logrado el intento" ${ }^{11}$. O último testemunho em termos cronológicos, pelo menos que até agora se conheça, diz respeito à fase final da missão e serve para mostrar o apreço com que o rei Filipe encarava o cuidadoso (e bem sucedido, diga-se) trabalho de espionagem de D. Pedro de Aragón: "Todo lo que habéis obrado y discurrís en estos puntos es propio de vuestra atención y celo de mi servicio, y así os lo apruebo, y doy gracias por lo que procuráis atravesar las negociaciones de ese Portugués" 12 .

Para além destas manobras mais insinuantes de espionagem e de contra-espionagem entre as duas partes envolvidas ou da ação diplomática regular, era muito comum a existência de campanhas de propaganda político-ideológica que se materializavam numa intensa difusão de textos panfletários ou papéis, como então se dizia. É muito significativo o número de impressos, redigidos em vários idiomas, que chegaram até nós, mas é legítimo pensar que no tempo que acompanha o movimento restauracionista e ao que se lhe seguiu o seu impacto tenha sido ainda mais notório. Ora, tanto quanto se sabe, pela mesma altura em que se desenrolava o périplo, que vimos referindo, por várias regiões da Europa (Inglaterra, França, territórios da Península Itálica), Manuel de Melo alimentava também a seu modo esta máquina de propaganda, redigindo e fazendo publicar panfletos em que se procurava exaltar o comportamento do país em vários domínios (da política ao confronto bélico, sem esquecer a extrema obediência do rei e do reino a Roma, mesmo quando esta abertamente fazia pouco caso dos seus mais legítimos interesses). É o que acontece com um texto publicado em 1663, sob o título de Declaración que por el reyno de Portugal ofrece el Doctor Geronymo de Santa Cruz a todos los reynos y provincias de Europa contra las calumnias de sus emulos, em Lisboa, pelo impressor António Craesbeeck de Melo, mas com várias

11 Prestage, 1914: 557 (documento n. ${ }^{\circ} 115$ ).

12 Prestage, 1914: 560 (documento n. ${ }^{\circ} 120$ ). 
reedições (como demonstrou Edgar Prestage ${ }^{13}$ ) e atribuível a Melo, por figurar no catálogo de obras que o próprio incluiu na edição de Obras Morales ${ }^{14}$.

Pontos mais obscuros do seu percurso vivencial, e ainda hoje à espera de clarificação definitiva, seja pelo desaparecimento de preciosa documentação como o seu processo judicial, seja pela parca informação que pode ser colhida nos textos que chegaram até nós, abriram caminho a um trabalho de produtiva figuração ficcional. São disso exemplo peças de teatro como Um duelo nas sombras ou D. Francisco Manuel de Melo (Lisboa, 1875) de António Francisco Barata, D. Francisco Manuel (Lisboa, 1914) de Ruy Chianca e, mais próximo de nós, a obra de ficção que Fernando Campos publicou em 2003, sob o título de O prisioneiro da Torre Velha. Quare?. Sensível ao valor romanesco da dinâmica de espionagem e de contra-espionagem, num contexto de apertadas movimentações nos corredores do poder, Campos soube tirar amplo partido da ficcionalização desta jornada diplomática de Lisboa a Roma, passando por França e Inglaterra ${ }^{15}$.

Sendo objetivo deste nosso estudo lançar também um olhar sobre o teor das relações diplomáticas do tempo barroco, creio que vale a pena considerar agora o retrato do perfeito embaixador que Melo propõe aos seus leitores na Visita das Fontes. Aí, a par de qualidades inerentes ao âmbito cortesanesco e de virtudes éticas e cristãs que uma longa tradição se encarregara de sedi-

13 Prestage, 1914: 581.

14 Em ensaio publicado em 2008, na revista Românica, Maria Lucília Gonçalves Pires levantou, pela primeira vez, a hipótese de ser este o "papel romano" que o Padre António Vieira severamente critica numa carta a D. Rodrigo de Meneses, datada de 8 de setembro de 1664, por não ser tão eficaz do ponto de vista persuasivo quanto a situação exigiria. Não se justifica repisar a meticulosa análise a que procede a estudiosa referida, revelando as informações que poderiam sustentar esta tese ou dando conta da especificidade da engrenagem retórico-estilística que o enforma, a ponto de torná-lo próximo de uma matriz muitas vezes presente em textos de reconhecida autoria de Manuel de Melo, pelo que nos limitamos a remeter o leitor para esse ensaio intitulado "Francisco Manuel de Melo e António Vieira”, pp. 133-150.

15 Sublinharemos apenas um segmento textual do penúltimo capítulo desta obra (justamente intitulado "Le Chevalier de Saint Clément") que aposta na ficcionalização de uma "sessão de lanterna mágica” levada a cabo, no âmbito do círculo cultural da rainha Cristina da Suécia, por Athanasius Kircher, homem notável do seu século e de quem falaremos mais pormenorizadamente adiante, numa demonstração prática de princípios teóricos gizados em vários tratados científicos seus, mas de modo especial em Ars Magna Lucis et Umbrae (Romae, Hermannus Scheus, 1646): "a um aceno da rainha, logo ele se coloca atrás de uma mesinha sobre que estava um estranho aparelho e uma vela acesa. Homem alto e magro, cabelos grisalhos a caírem-lhe sobre os ombros, labita negra de jesuíta, num italiano com toada alemã pediu a atenção da assembleia para a parede branca do fundo da sala. Fez sinal aos criados, que, junto das janelas, cerraram as cortinas, e na parede começaram a surgir figuras de pessoas, coisas, animais em corpo grande, no silencioso assombro da assistência ... um gato, uma caleça tirada por cavalos, um jesuíta, o cardeal Orsini, o papa Alexandre bem reconhecível...", Campos, 2003: 398. 
mentar, contam-se aspetos mais discutíveis (e, de facto, na altura amplamente discutidos):

primeiro que tudo, necessita este ofício de hũa agradável presença e saúde corporal, boa graça e arte na conversação, notícias vivíssimas dos sucessos do mundo, desinteresse invencível, ânimo temperado, razões modestas, coração forte, prudente liberalidade, diligência activa, arte, despejo, e tal vez dizem que não perderá nada na mentira, fingimento e simulação, tudo adubado da malícia quanto baste a não ser enganado. (Melo, 1962: 227-229; itálico nosso)

Cumpre notar, porém, que a parte final desta intervenção suscitou amplas reservas junto das restantes personagens deste apólogo dialogal - como, de resto, também viria a acontecer com os censores que não hesitaram, na edição de 1721 , em modificá-la ${ }^{16}-$, uma vez que não é de ânimo leve que se pode admitir num "homem de bem", como protesta a Fonte Nova, a prática da mentira, do fingimento e da simulação. Ora, é justamente este o ponto que importa sublinhar: ainda que o pacto ficcional que subjaz à obra nos impeça de estabelecer uma filiação direta entre as opiniões manifestadas pelas personagens e o juízo que o autor teria sobre a matéria, não deixa de ser curioso verificar que se apregoa, quanto mais não seja num plano retórico, a insensatez (pecaminosa, subentende-se) deste procedimento, quando se sabe que no campo diplomático a verdade desnudada podia, nalguns casos, ter custos elevados. Sabia-o D. Francisco como homem experiente que era - ainda que a redação dos apólogos seja anterior a decisivas missões diplomáticas que levou a cabo nos últimos anos da sua vida -, pelo que subtilmente deixa de lado deste lote de estratégias condenáveis, por desonestas, a dissimulação. A preocupação, que sempre demonstra nos seus escritos, com a dimensão ética e moral não o impede de ver as adversas condições que a realidade punha diante dos olhos dos que tinham que negociar ou desempenhar determinada missão política.

16 Giacinto Manuppella, responsável pela edição que aqui utilizamos, chama a atenção para este facto em nota ao passo citado, transcrevendo as alterações introduzidas (Melo, 1962: 543-546) e sublinhando o âmago da questão nestes termos: "entre 1580 e 1650, nesse clima contra-reformista um tanto pesado e circunspecto, embora animado de vivos e sinceros anseios de regeneração dos valores morais e religiosos, em Itália e fora multiplicaram-se desmedidamente os tratados da arte de governar os povos, todos eles ansiosos de resolver plena e definitivamente o problema espinhoso das relações entre política e moral (que Maquiavel - é preciso que se note - não destruíra, pela simples razão que nunca tinha existido o problema), de descobrir e focar a maneira de harmonizar as exigências de uma religiosidade revigorada (em parte por meios exteriores, e portanto receosa e acanhada) e o irreprimível desejo de debruçar-se sobre as inúmeras acções aberrantes que a inteligência humana sugere e orienta, quando estimulada pela ambição, pelo interesse, ou por outras paixões ainda menos recomendáveis». 
3. Passemos agora a um outro plano: quando se observa de forma atenta a produção de Manuel de Melo, depressa se percebe que as experiências colhidas durante as suas viagens (independentemente da motivação que estava na sua origem: política, militar, diplomática ou outra) podiam facultar material para o seu processo criativo, numa assumida demonstração de cosmopolitismo intelectual e vivencial. Roma, nesse sentido, não constituiu exceção e assim, num passo da Carta de Guia de Casados, obra especialmente entretecida com o relato de contos, ditos, provérbios ou sentenças que põem em evidência um estilo de conversação "agudo" e "engenhoso", puxa para primeiro plano um episódio de tom mais gracioso. Segundo recorda, um seu conhecido, Gonçalo Correia de Sousa, homem fortemente empenhado no processo de beatificação de Margarida de Chaves, sua mãe, a tal ponto que chegou mesmo a escrever e publicar um Breve compêndio com os principais sucessos da vida daquela virtuosa senhora, deslocou-se a Roma para mais depressa conseguir realizar esse intento, mas sem êxito. Ficou, contudo, o rasto da sua inquebrantável perseverança:

Solicitava com exquisita importunação em Roma a beatificação da venerável matrona Margarida de Chaves um seu filho, que eu muito bem conheci, e de sua boca ouvi o que digo. Tinha o Papa Paulo Quinto remetido a causa a certo cardeal que já andava tão temeroso do requerente que, em o vendo, fugia dele. Sucedeu chegar a falar-lhe um dia, estando o cardeal mais que outros enfadado e, havendo-lhe lembrado, como costumava, seu negócio, lhe respondeu: Senhor, não nos cansemos em provas da santidade de vossa mãe; prova somente que vos sofreu que o Papa a declarará logo por santa. (Melo, 2003: 122)

Sabemos que do ponto de vista político a sua ação foi pouco mais do que infrutífera, por não ter conseguido resolver o problema do casamento de Afonso VI e obtido do Papa a nomeação de prelados portugueses para os lugares que se encontravam vacantes, mas é de crer que tenha desfrutado, com a sapiência que só os anos sabem proporcionar, desse convívio culto que a cidade propiciava. Encontrando-se já em Lyon (França) em 1665 e sob o pretexto de ter publicado em Roma, no ano anterior, o primeiro dos dez volumes em que tinha dividido o conjunto da sua produção escrita, o das Obras Morales, Melo faz referência à vertente cultural da sua estada em termos que aqui importa recuperar ${ }^{17}$ :

17 Melo fala deste seu ambicioso projeto (e talvez por isso inacabado) precisamente na altura em que apresenta as Obras Morales: era seu desejo reunir em vários volumes as suas Obras Políticas, Históricas, Métricas, Demonstrativas, Solenes, Exquisitas, Várias, Familiares e Imperfeitas, distribuindo o trabalho de impressão por cinco oficinas tipográficas de vários países europeus. 
De entre las águilas de Roma, no ha mucho tiempo, oh, letor mío!, que viste volar mi pluma a las más sublimes moralidades. Confieso que no por eso te habrá parecido de águila, mas de milano tampoco. Linaje sería de ingratitud desconocer yo en mí proprio los alientos, que con ejemplos, y doctrinas, pudo haberla importado la compañía, amistad, y prática, de tantos varones sabios, cuantos en la corte romana agora resplandecen. (Melo, "A los letores de mis Obras Métricas”, 2006: I, 7)

É com indisfarçável orgulho que ostenta, no início da advertência aos leitores de Obras Métricas uma lista de afamados intelectuais que se encontravam em Itália quando ele por lá passou e com os quais manteve contacto próximo. Como confessa já na parte final desse parágrafo consagrado à experiência italiana: "Todos los cuales, agora con eruditísimos escritos, agora con atentísimas conferencias, han socorrido o labrado mi ignorancia, de tal modo que yo no pasaría más allá de mi obligación, o de su esperanza, habiéndome aprovechado lucidamente de tan caudalosos socorros"18. Fazendo jus a uma convicção muito generalizada no século XVII europeu, reconhece-se que a amizade e o convívio com homens de elevada estirpe favoreciam o aperfeiçoamento pessoal, pelo que se percebe o seu empenho em fazer parte desse circuito.

Proceder aqui a um levantamento exaustivo dos contactos que estabeleceu torna-se algo difícil em função do espaço disponível, mas não queremos ainda assim deixar de contemplar esta vertente, até porque se revela útil para a consideração do modelo de homem discreto que Manuel de Melo tão bem encarna. Sendo a sanção pública um fator determinante para que alguém possa ser tido em conta como tal, não é conveniente descurar essa teia de afinidades que se vão tecendo entre indivíduos que mutuamente se reconhecem como parte integrante de uma elite intelectual.

Estrategicamente colocado à cabeça da referida lista, ou não fosse a personalidade de maior renome a nível internacional, encontra-se o jesuíta alemão Athanasius Kircher, um dos mais famosos membros da Companhia de Jesus e, nas palavras de Melo, "autor de los más portentosos destos tiempos, igualmente en la solidez que en la sutileza y en la raridad de sus escriptos". Diga-se, em abono da verdade, que as palavras com que brinda esse "rarísimo ingenio" não são de todo exageradas, pelo alcance da sua produção fortemente eclética, capaz de cobrir campos tão distintos quanto os da ciência óptica, da música, da física, da história, da filologia, da egiptologia ou do

18 Melo, 2006: I, p. 7. 
magnetismo, para não alongar mais a lista. Caberia aqui recordar, por muito adequados, um ou outro epíteto que estudiosos recentes lhe têm atribuído, como acontece com o volume coordenado por P. Findlen - the last man who knew everything - ou em obras publicadas por J. Godwin - the last man to search for universal knowledge - e por C. Reilly - a master of a hundred arts -, porque manifestam, com meridiana claridade, a insaciável sede de saber que fez deste homem um dos mais notáveis do seu século ${ }^{19}$. Ficou famoso o seu Museum Kircherianum, instalado no Colégio Romano, por nele se recolher toda uma série de objetos de história natural, de antiguidades e de extraordinárias máquinas pneumáticas, hidráulicas e magnéticas, o que demonstra bem a transversalidade dos seus interesses ${ }^{20}$. Como tem sido notado frequentes vezes, esse projeto de Kircher revestiu-se de caráter pioneiro, até por ter apostado numa feliz combinação de traços próprios de um "gabinete de curiosidades" (Wunderkammer) com a matriz que enforma o museu cientifico, mostrando, de modo inequívoco, a proeminência da maravilha na cultura da primeira Modernidade. ${ }^{21}$

19 Para benefício de leitores interessados em aprofundar esta vertente do pensamento e da ação de Kircher, deixamos aqui a indicação bibliográfica completa: Paula Findlen (ed.), Athanasius Kircher: The Last Man Who Knew Everything, New York, Routledge, 2004; Joscelyn Godwin, Athanasius Kircher's Theatre of the World: The Life and Work of the Last Man to Search for Universal Knowledge, Rochester, Vt., Inner Traditions, 2009; Conor Reilly, Athanasius Kircher: a master of a hundred arts, 1602-1680. Studia Kircheriana, Wiesbaden, Edizioni del Mondo, 1974.

20 Muito embora não sofra contestação o seu estatuto como um dos mais destacados eruditos do seu tempo, tendo alcançado uma forte projeção internacional junto de uma vasta comunidade de leitores, formada quer por estudiosos, quer por gente que pretendia apenas alimentar a sua curiosidade intelectual, de gozar do apoio mecenático de príncipes poderosos e de ter conseguido inscrever o seu museu do Colégio Romano na rota cultural dos curiosi que visitavam a cidade de Roma, o certo é que a posteridade não soube fazer jus ao seu real valor. Contrariando essa tendência, nos últimos anos tem crescido, de modo significativo, a produção bibliográfica sobre este homem e sobre o seu legado cultural, como se pode ver, só a título de exemplo, por trabalhos como os de Ingrid Rowland, The Ecstatic Journey: Athanasius Kircher in Baroque Rome (Chicago, University of Chicago Press, 2001); Daniel Stolzenberg (ed.), The Great Art of Knowing: The Baroque Encyclopedia of Athanasius Kircher, Stanford University Libraries, 2001; Eugenio Lo Sardo (ed.), Iconismi \& Mirabilia da Athanasius Kircher, Roma, Edizioni dell'Elefante, 1999; M. Casciato, M. Ianniello e M. Vitale (eds.), Enciclopedismo in Roma barocca: Athanasius Kircher e il museo del Collegio Romano tra Wunderkammer e museo scientifico, Veneza, Marsilio, 1986; Paula Findlen, "Scientific Spectacle in Baroque Rome: Athanasius Kircher and the Roman College Museum”, Roma Moderna e Contemporanea, 1995; 3, pp. 625-665; P. Findlen, Possessing Nature: Museums, Collecting, and Scientific Culture in Early Modern Italy, Berkeley, University of California Press, 1994.

21 Sobre esta questão, valeria a pena ter em conta o ponto de vista manifestado por Koen Vermeir em "Wonder, magic and Natural Philosophy. The disenchantment thesis revisited": "The wunderkammer is a sign of the times, and attests to the prominence of wonder, but it also reflected distinctions present in the broader cultural setting. Kircher's museum, for instance, was like a big show, similar to illusionist paintings or baroque theatres excelling in stage machinery, devised to baffle courtiers and dignitaries. I have already related that Athanasius Kircher's artificial marvels sometimes had a 


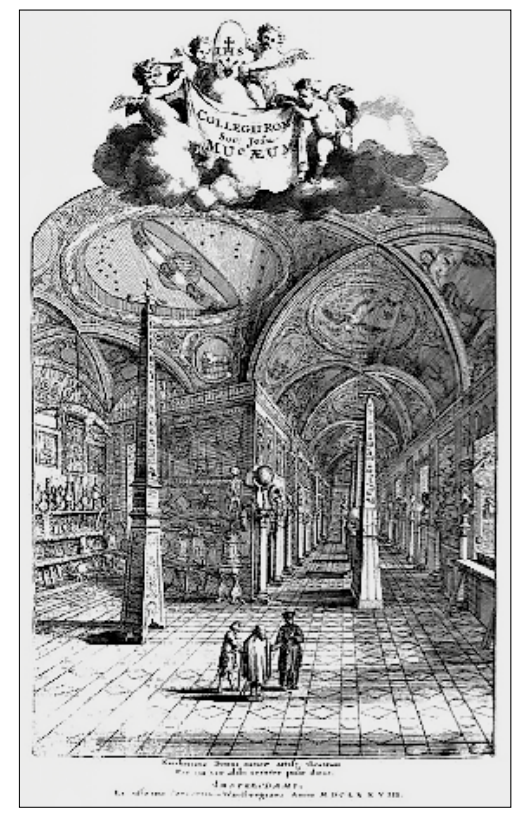

Museum Kircherianum, Giorgio de Sepibus, Romani Collegii Musaeum Celeberrimum, Amsterdam, Ex Officina Janssonio-Waesbergiana, $1678^{22}$

Ora, perante um homem com este perfil, e numa altura em que os intelectuais, um pouco por toda a Europa, se viam a si mesmos como cidadãos de uma sociedade transnacional - a República das Letras - em que o mérito se sobrepunha à qualidade do nascimento, é natural que Melo procurasse ter acesso a esse tão celebrado horizonte de sociabilidade. A prová-lo está o facto de o seu nome constar de uma longa lista de correspondentes com Kircher que só muito recentemente ficou conhecida em toda a sua extensão ${ }^{23}$.

moral significance, but more often it represented religious and political messages. It was a museum of wonders for the elite, where the latest techniques and inventions found a place in a Catholic framework, and Kircher played with hidden messages that served to reinforce his religious position. The common man, it was supposed, was prone to superstition. Only the educated gentry were able to enjoy the play and read the hidden messages. Marvellous devices referred to the incapacity of the vulgar and helped constitute a distinct elite epistemic culture", in M. Deckard and P. Losonczi (eds.), 2009: 50.

22 Reprodução da imagem disponível em: http://www.stanford.edu/group/kircher/cgi-bin/site/ [consulta: 5.X.2015].

23 No âmbito do projeto 'Athanasius Kircher at Stanford' foi levada a cabo uma campanha de digitalização da correspondência do jesuíta alemão, que se encontra guardada principalmente nos arquivos da Pontificia Università Gregoriana, e do elenco de material recolhido faz parte uma carta enviada por D. Francisco Manuel de Melo, que comprova de modo inequívoco o estabelecimento de contacto entre as duas figuras (http://web.stanford.edu/group/kircher/cgi-bin/site/?page_id=7). 
Entre os portugueses que se encontravam também por lá nessa altura e com quem terá privado (a acreditar no seu próprio testemunho) merece destaque especial Frei Francisco de Santo Agostinho de Macedo, religioso, qualificador do Santo Ofício da Inquisição romana, poeta, diplomata, Mestre de Controvérsia no Colégio De Propaganda Fide e, mais tarde, Lente de História Eclesiástica na Sapienza ${ }^{24}$. Da recolha levada a cabo com vista à publicação do volume de Cartas Familiares infelizmente apenas faz parte uma missiva dirigida a Macedo, de 23 de fevereiro de 1648, em agradecimento pela diligência que este fizera junto da monarquia francesa para lhe obter uma carta de intercessão do rei no período em que se encontrava preso, mas é perfeitamente legítimo supor que a troca epistolar, ao longo de anos, tenha sido muito mais intensa ${ }^{25}$. Em todo o caso, é de acreditar que a amizade entre Melo e Macedo tenha contribuído para uma integração ainda mais rápida e frutuosa daquele nos mecanismos de sociabilidade intelectual que o próprio meio romano estimulava. Que a fama da sua elevada erudição lhe granjeava um estatuto singular não resta hoje qualquer dúvida, mas Melo tem o cuidado ainda assim de recordar esse facto: "Así en la opulencia de las buenas y de las mejores letras, humanas y divinas, nuestro insigne y nuestro preceptor y amigo, el P. M. F. Francisco de Macedo, cuyos copiosos caudales logran admirablemente dos cátedras, muchos púlpitos, no pocos tribunales e innumerables tipos"26.

Mas, o que talvez mais impressione o leitor - a começar, como é evidente, pelo da época em que a obra foi publicada - é a abrangência enciclopédica dos saberes que no seu todo as duas dezenas de nomes representam ${ }^{27}$. A cada um deles corresponde em especial uma fração desse vastíssimo campo do saber - humanidades, matemáticas, divinas e humanas letras, etc. -, mas

24 Temos notícia de que Macedo foi responsável, em nome do Colégio De Propaganda Fide, por uma das aprovações (datada de 24 de fevereiro de 1661) que acompanham a edição de uma obra de Kircher: Ars Magna sciendi, in XII libros digesta, qua nova \& universali methodo per artificiosum combinationum contextum de omni re proposita plurimis \& prope infinitis rationibus disputari, omniumque summaria quaedam cognitio comparare potest. Ad augustissimum Rom. imperatorem Leopoldum primum, justum, pium, felicem.

25 Melo, 1981: 177-178.

26 Melo, 2006: I, 7.

27 Para além de Kircher e de Francisco de Macedo já referidos, faz menção explícita a vários intelectuais de renome (e seguimos a grafia proposta neste seu texto): "P.M.F. Lorenzo Brancatto de Lauria"; "P. Jerónimo Petruche"; "P.F. Felipe de la Trinidad”; "P. Sebastián Beluche”; "P. Ignacio Bompiano"; "P.F. Lorenzo de S. Pablo"; "P. Felipe Marino"; "Doctor Miguel Angelo Lualde”; "Dotor Felipe Maria Bonini"; "Dotor Iacobo Gibessio Albano"; "Dotor Bernardo de Almeida"; "Dotor Francisco Lavera”; "P. Maestro Gottinis"; "Leo Alassio”; "Abrahamo Maronita”; "Juan Batista Ionás”; “Tomás de Rivera"; "abad D. Martín de Mesquita”. 
ao mostrar que comunicou com todos eles consegue projetar a imagem de um homem discreto, capaz de operar uma produtiva síntese intelectual. Em suma, para a sua curiosidade sempre desperta, o convívio com grandes figuras da Companhia de Jesus, que de todo o mundo chegavam à Cidade Eterna por esses anos, e com gente de elevada estirpe que pertencia a círculos de cultura eclesiástica e laica, revelar-se-ia por certo muito estimulante ${ }^{28}$.

4. Em suma, pelas suas qualidades e temperamento, D. Francisco Manuel de Melo aproximava-se, sem dúvida, da imagem do perfeito legado ou agente diplomático, muito embora a conjuntura política dificilmente pudesse propiciar ações de assinalável êxito neste campo. Na verdade, de pouco importa o ângulo de análise adotado, pois uma verdade subsiste: a história pessoal do autor confunde-se com o destino político dos povos peninsulares e isso confere-lhe uma dimensão única no quadro da cultura e da sociedade do século XVII. Não é apenas um autor de textos que assim se dá a ver, é um homem que foi, nesta como noutras circunstâncias, também ator e testemunha privilegiada de acontecimentos históricos relevantes.

Em todo o caso, pela gostosa combinação de política, de convivialidade discreta e de fervente atividade cultural, a viagem a Itália de D. Francisco - e de modo especial a sua passagem por esse grande teatro do mundo que era, por então, a cidade de Roma - emerge como decisiva na fase mais derradeira do seu atribulado percurso de vida. Para um homem que acreditava que "entre os sábios não há nações” (a expressão surge na boca da personagem Quevedo de Hospital das Letras, mas aquele podia sem dificuldade subscrevê-la ${ }^{29}$ ) e que não há nada como ser "cidadão do mundo todo", muito deveria significar esta calorosa receção no ambiente intelectual além-fronteiras. Repetidas vezes vem ao de cima, em modos vários, esse sentimento de pertença a uma elite que, mesmo quando não ocupava lugares de prestígio ou de poder na orgânica da sociedade, se sentia superior - e fazia gala que os outros também a reconhecessem como tal - em termos espirituais, morais ou culturais.

Se se procurar compreender um pouco mais a fundo a raiz da sua fama como escritor, há uma forte probabilidade de encontrar entre os seus mais

28 Serviria ainda esta sua viagem para promover o seu projeto de compilação e posterior edição das obras em locais de forte prestígio cultural a nível europeu. Que circulava também com alguma destreza pelos meandros do universo editorial da cidade, é algo que bem se percebe pelo facto de aí ter saído, no ano de 1664, dos prelos de Filipe Maria Mancini, a edição das suas Cartas familiares escritas a várias pessoas sobre assuntos diversos. Reunira-as, em cinco centúrias, o seu amigo António Luís de Azevedo, abrindo assim caminho à publicação da primeira coletânea de cartas escritas em português intencionalmente preparada sob supervisão do seu autor.

29 Melo, 1970: 93. 
decisivos fatores a conciliação entre um saber literário e cultural que só alguns estavam em condições de manifestar com uma experiência de vida e de relacionamento social que lhe permitia descer bem fundo na anatomia do espírito humano. Raro é o estudo que buscando esmiuçar a obra não se vê obrigado a convocar argumentos que pertencem ao plano da vida do homem que está por detrás dela, sem que isso possa ser visto como abordagem meramente biografista. Não causa estranheza, portanto, verificar que entre os mais íntimos conhecedores da sua escrita se contam alguns que, de forma mais ou menos pronunciada, se ocuparam do percurso de vida do autor, a começar por Edgar Prestage, o lusitanista britânico que consagrou longas horas ao estudo desta matéria. A questão é, como têm admitido os estudiosos da época histórico-literária que se convencionou chamar 'barroca', muito mais complexa, pois mesmo quando não escrevia para falar de si próprio, deixava que a sua voz íntima, ora pelo entusiasmo que nutria por alguns dos temas que tratou, ora pelo pessimismo que vicissitudes pessoais haviam despoletado, se intrometesse no tecido ficcional ou nos largos cenários dos acontecimentos históricos que expôs, para só citar duas áreas estratégicas a este nível.

\section{Bibliografia}

CAMPOS, Fernando (2003). O prisioneiro da Torre Velha. Quare?. Algés: Difel.

FARIA, Ana M. H. Leal de (2011). "Missões secretas e negociações. D. Francisco Manoel de Mello e D. Francisco de Mello Manoel ao serviço da Coroa portuguesa", in M. R. Pimentel e M. R. Monteiro (eds.), D. Francisco Manuel de Melo - O Mundo é Comédia. Lisboa: Edições Colibri, pp. 211-234.

GODINHO, P.e Manuel (1974). Relação do novo caminho que fez por terra e mar vindo da Índia para Portugal no ano de 1663. Introdução e notas por A. Machado Guerreiro, Lisboa: Imprensa Nacional-Casa da Moeda.

PRESTAGE, Edgar (1914). D. Francisco Manuel de Mello. Esboço biográfico. Coimbra: Imprensa da Universidade.

MELO, D. Francisco Manuel de (1970). Le dialogue "Hospital das Letras" de D. Francisco Manuel de Melo. Texte établi d'après l'édition princeps et les manuscrits, variantes et notes de Jean Colomès. Paris: Fundação Calouste Gulbenkian - Centro Cultural Português.

MELO, Francisco Manuel de (2006). Obras Métricas. Edição coordenada por Maria Lucília Gonçalves Pires e José Adriano de Freitas Carvalho. Braga: Edições APPACDM de Braga.

MELO, D. Francisco Manuel de (1981). Cartas Familiares. Prefácio e notas de Maria da Conceição Morais Sarmento, Lisboa: Imprensa Nacional-Casa da Moeda. 
MELO, D. Francisco Manuel de (1962). A Visita das Fontes. Edição fac-similada e leitura do autógrafo (1657), introdução e comentário por Giacinto Manuppella, Coimbra: Acta Universitatis Conimbrigensis.

MELO, D. Francisco Manuel de (2003). Carta de Guia de Casados. Edição de Maria de Lurdes Correia Fernandes, Porto: Campo das Letras.

PEREIRA, Paulo Silva Pereira (2007). D. Francisco Manuel de Melo e o modelo do cortesão prudente e discreto na cultura barroca peninsular. Coimbra: Faculdade de Letras da Universidade de Coimbra [Tese de Doutoramento policopiada].

PIRES, Maria Lucília Gonçalves (2008). “Francisco Manuel de Melo e António Vieira”, in Românica. Revista de Literatura, n. ${ }^{\circ}$ 17, Lisboa: Departamento de Literaturas Românicas da Faculdade de Letras da Universidade de Lisboa, pp. 133-150.

VERMEIR, Koen (2009). "Wonder, magic and Natural Philosophy. The disenchantment thesis revisited”, in M. Deckard and P. Losonczi (eds.), Philosophy Begins in Wonder. Eugene: Wipf and Stock, pp. 43-71. 



\title{
En torno a una traducción inglesa del Buscón. "The pleasant story of Paul of Segovia”, 1683 \\ Around an English translation of the Buscon: "The pleasant story of Paul of Segovia", 1683
}

\author{
J. EnRiQue Duarte \\ Universidade de Navarra - GRISO \\ eduarte@unav.es
}

Texto recebido em / Text submitted on: 10.09.2015

Texto aprovado em / Text approved on: 18.10.2015

Resumen: El presente artículo analiza una breve traducción del Buscón de Quevedo inserta en un libro titulado: The Famous History of Auristella, Originally Written by don Gonsalo de Cespedes. Together with the Pleasant Story of Paul of Segovia, by Don Francisco de Quevedo. Translated from Spanish y publicado en Londres en 1683. En el artículo se muestra que el autor, desconocido e identificado únicamente con las iniciales W.B., sigue los originales españoles publicados a partir de la edición de Zaragoza (1626). Es curioso que esta traducción del Buscón se aparte de la primera traducción inglesa de esta obra, realizada por John Davies en 1657 y que tiene como modelo la traducción francesa de 1633.

Palabras clave: Francisco de Quevedo; El Buscón; Traducción Inglesa, 1683

Abstract: This article analyses a brief translation of the Buscón by Francisco de Quevedo within a book whose title is: The Famous History of Auristella, Originally Written by don Gonsalo de Cespedes. Together with the Pleasant Story of Paul of Segovia, by Don Francisco de Quevedo. Translated from Spanish and published in London, 1683. This article proves that the author of this book, still known by his initials W.B., follows the Spanish originals from the printed edition published in Zaragoza, 1626. It is curious to note that this work published in 1683 does not follow the first English translation made by John Davies in 1657, which depends completly on the French made in 1633.

Keywords: Francisco de Quevedo; El Buscón; English translation, 1683

\section{Introducción}

El interés de Inglaterra por la literatura española de los Siglos de Oro se manifiesta de forma clara en la cantidad de traducciones existentes de 
obras de nuestra literatura ${ }^{1}$. Para Navarro Errasti (1980: 155-156), el siglo XVII ve en Inglaterra el apogeo de los temas españoles que se manifiestan de forma contundente en la Corte de Carlos I con la visita que realiza a Madrid en 1623 (Jauralde 1999: 466 y ss.), siendo príncipe de Gales, y en la que le acompañan hombres de letras como John Mabbe y James Howell y las representaciones que una compañía de actores españoles realiza el 23 de diciembre de 1635 en la corte inglesa. Uno de los autores que tienen una relativa importancia, todavía por determinar en esta influencia de la literatura española, es Francisco de Quevedo.

Don Francisco, y especialmente su Buscón, al que voy a dedicar estas páginas, consiguen atraer la atención de Europa que le dedica diversas traducciones, partiendo de la francesa de 1633 por La Geneste que resulta ser la base de otras traducciones como la príncipe inglesa de John Davies de Kidwelly (con una segunda edición en 1670), la holandesa de 1642 o la alemana de 1671 (Roig Miranda 2003: 250). Todas estas traducciones muestran un final dulcificado muy diferente del original. Sin embargo, la traducción italiana con la que contamos y que se fecha en 1634 no sigue esa dependencia de la traducción francesa (Martinengo y Símini 2003. Ver también Navarro Errasti 1987b: 166).

Respecto a la relación de Quevedo e Inglaterra, la crítica se fija en dos aspectos: el primero intenta explicar las posibles influencias del autor madrileño en la literatura inglesa y, en segundo lugar, se enumeran las distintas traducciones de sus obras al inglés.

En cuanto a la influencia, hay dos tendencias. Una representada por Barker, para quien Quevedo no pudo influir en la literatura inglesa, ya que su estilo y su visión de España estaban muy alejados de la visión que de nuestro país tenían los lectores ingleses:

Las dificultades de estilo, mal gusto y retruécanos pueden explicar en cierta medida el olvido (en comparación con un Cervantes, por ejemplo) en que han caído las obras de Quevedo, pero el verdadero motivo se halla en algo más hondo y arraigado. El inglés medio ve a España de un lado como un país de romance, país de ensueño y de amor romántico, de alegría y de sol, de buen vino y buen pan, de picardías picarescas y de lances de humor. La visión negra de Quevedo está en plena contradicción con tal visión. Del otro lado, el inglés del siglo XVII leía con afán los manuales de devoción y los tratados de los

\footnotetext{
Ver, por ejemplo, "Los siete libros de la Diana" de Jorge Montemayor (Chamosa 1987), las traducciones del "Quijote" (Cunchillos 1987), "La Celestina" (Guardia Massó 1987), "Las novelas ejemplares” (Luttikhuizen 1987), "El Lazarillo” (Santoyo 1987) o "El Guzmán de Alfarache” (Verdaguer Clavera 1987).
} 
ascéticos y místicos españoles. La sátira y la suciedad de Quevedo tampoco encajaban con este país místico que admiraban y temían los ingleses. [... El El amargo Quevedo con su sátira y sus sufrimientos personales, destruía esa ilusión (Barker 1945: 434-435).

\section{Sin embargo, para Navarro Errasti:}

La proyección británica de Quevedo es ciertamente considerable. Las numerosas ediciones de los Sueños en los siglos XVII y XVIII vienen a justificar el hecho de que a Quevedo se le conociera en Inglaterra como autor de éstos, aunque como se ha visto, otras obras suyas, y en particular el Buscón, adquieren una difusión nada despreciable. Quevedo, pues, no es desconocido en Gran Bretaña; si su huella no ha sido más decisiva en la literatura inglesa, considero que se debe principalmente a la complejidad conceptista de su estilo, la cual es causa de que a la hora de traducir sus escritos se presenten dificultades insalvables que redundan en la pérdida de la más pura esencia quevedesca, dando lugar, en ocasiones, a textos carentes de originalidad que difícilmente pueden tomarse como modelo (Navarro Errasti 1980: 163)

Para Arbesú, la influencia de Quevedo en Inglaterra es semejante a la de Cervantes y analiza un libro de 1684 titulado The Travels of don Francisco de Quevedo through Terra Australis Incognita en el que Quevedo es el protagonista utilizado para atacar a su propio país y a la religión católica. Este hecho le lleva a pensar que la popularidad de nuestro escritor en la época de los Estuardos era enorme:

la popularidad de Quevedo en la Inglaterra de los Estuardos es muchísimo mayor de lo que la crítica ha apuntado hasta el momento, llegando incluso a competir con la de Miguel de Cervantes (1547-1616). Las ediciones de las obras de Quevedo en este país nada tienen que envidiar a las de Don Quijote, y las numerosas referencias a Quevedo en las antologías literarias de la época superan con creces a las de cualquiera de sus contemporáneos españoles. Por otra parte, la publicación de Los viajes a finales del XVII hace de este libro el último ejemplar de una serie de obras -legítimas o falsas- que los ingleses utilizaron para modelar una imagen particular de Quevedo de acuerdo con los intereses de la época. Intentaremos demostrar, pues, que existió una corriente literaria que aprovechó la popularidad de Quevedo entre el público inglés, además de su condición de español, para forjar una ideología determinada sobre su figura, ya sea como autor (al traducir o adaptar muchas de sus obras) o como personaje (al incluirlo en relatos tan extravagantes como el de Los viajes). (Arbesú 2006: 318) 
Los editores ingleses comienzan a traducir a Quevedo tan pronto como 1640, pero casi inmediatamente encontramos el siguiente paso: falsificar las obras o la personalidad de Quevedo para conseguir un efecto determinado en el público inglés. No es este el lugar para realizar una enumeración de todas las traducciones inglesas de las obras de Quevedo, pero creo que es interesante, para situarnos en este ambiente, explicitar que estas traducciones durante el siglo XVII comienzan con la edición de los Sueños en 1640 por Richard Croshaw quien traduce cinco sueños ${ }^{2}$. Sigue la traducción en 1641 de dos sueños por Edward Messervy, publicados estas dos primeras ediciones por el mismo librero. Encontramos a continuación la traducción de Roger L'Estrange en 1668, con dos ediciones, una de ellas pirata; 1673, la quinta; 1678, la sexta; 1689, la séptima. Richard Sare y E. Hindmarsh se encargan de la octava en 1696; la novena, en 1702; la décima en 1708 y la undécima en 1715 (Navarro Errasti 1980: 159 y ss).

En 1657 se publica la primera traducción del Buscón al inglés por John Davies, ciudadano galés de Kidwelly:

The Life and Adventures of Buscon The Witty Spaniard. Put into English by a person of Honour. By Don Francisco de Quevedo, a Spanish Cavalier, London, Printed by J.M. for Henry Herringman, 1657.

John Davies no conocía la lengua castellana y traduce desde la edición francesa de 1633 con la que muestra "una dependencia total" (Navarro Errasti 1980: 160, n. 30. Ver también Navarro Errasti 1987a). Sin embargo, es un trabajo importante del que el traductor galés se sentía muy orgulloso, ya que se lo dedica a un amigo español que le recomendó vivamente este libro a pesar de que tiene cambios tan importantes que lo alejan definitivamente de la versión española ${ }^{3}$.

Tras una segunda edición de esta traducción en 1670, la siguiente etapa la representa un libro de 1683, cuyo título es el siguiente:

The Famous History of Auristella, Originally Written By Don Gonsalo de Cespedes. Together With the Pleasant Story of Paul of Segovia, by Don Francisco de Quevedo. Translated from the Spanish, London, Printed for Joseph Hindmarsh, Bookseller to his Royal Highness, at the Black Bull in Cornhil, 1683.

\footnotetext{
Ver Navarro Errasti 1980: 158 y ss.

Navarro Errasti 1987b: 182: "La versión inglesa es un buen trabajo, hecho con precisión y literalidad como rasgos dominantes, pero en absoluto es la traducción del Buscón de Quevedo; es la traducción de la obra francesa de la Geneste”.
} 
Esta traducción es la que me propongo analizar en estas páginas. Por lo visto hasta ahora, nos daremos cuenta de que las traducciones inglesas del siglo XVII distan bastante de lo que entendemos hoy en día por traducción. Para Santoyo:

El traductor inglés de lengua española, nunca profesional durante el siglo XVI, no se sentía (en principio) atado a forma alguna del original. [... ] Traducir no era todavía un oficio, ni un arte, sino una actividad marginal que muy pocos iban a censurar, entre otras razones porque eran muy pocos los que entendían o podían disponer del original con vistas a una comparación. [...]. Consideraban la traducción de cualquier volumen como "un acto de patriotismo", en palabras de F. O. Matthiessen, más que como una actividad literaria (Santoyo 1987.38-39)

\section{La traducción del Buscón de 1683}

El traductor de este libro se presenta con sus iniciales W.B. y dedica su trabajo a la honorable Lady Henrietta Grenville, de la que se declara pariente; hasta ahora la crítica no ha podido desvelar el nombre completo del traductor.

Este libro está organizado en tres secciones: la primera parte es una traducción de una novela de Gonzalo de Céspedes procedente de su Poema trágico del Español Gerardo y desengaño del amor lascivo (Madrid, 1615); la segunda parte es la traducción del Buscón de Quevedo, que voy a analizar más en profundidad, y la tercera es una traducción de la Carta de las cualidades de un casamiento traducida como On the qualities of a Marriage; or certain Rules for the choise of a Wife in a letter to the Countess of - "Sobre las cualidades de un casamiento; o ciertas reglas para la elección de una esposa en una carta a la condesa de-"

\subsection{The famous history of Auristella}

Resulta de la traducción de una de las novelas que se encuentran al comienzo del Discurso segundo de la Primera parte del Poema trágico del Español Gerardo y desengaño del amor lascivo, del que he podido consultar una edición de 1788. La traducción al inglés ocupa las 65 primeras páginas. 
Se trata de un historia de honor y crímenes, que los lectores ingleses encontrarían muy interesante.

En general, esta traducción sigue muy de cerca el argumento de Céspedes, aunque con unos significativos cambios de nombres: Isdaura aparece como Auristella, Roberto como Philander y Leriano como Bennato. El padre de Isdaura, Leonardo Argentino, es en la traducción inglesa Lorenzo D’Spazo, la criada Julia es Mariana y el mayordomo vizcaíno, Andreo. El viaje a América de los progenitores de Roberto e Isdaura es sustituido por un viaje a Flandes.

\subsection{The pleasant story of Paul of Segovia}

Esta sección del libro ocupa de la página 66 a la 120, y viene a corresponder a una diez páginas de un libro normal. Nos encontramos con un Buscón abreviado que presenta un total de 5400 palabras y está formado por 4 bloques argumentativos:

a) El primero de ellos es una introducción en la que muestra su procedencia (de Sigovia) y presenta a sus padres, Clement y Aldonce, y sus oficios: ladrón él y reparadora de virgos ella. Este bloque temático tiene una extensión total de 2,41\% del total (127 palabras).

b) El segundo bloque es el correspondiente a la escuela, en el que se cuenta la amistad con Diego Coronello, la aventura con Poncio de Aguirre y finaliza con el episodio del Rey de gallos y la batalla nabal. Este bloque temático posee una extensión total del 11,90\% (638 palabras).

c) El tercer bloque temático corresponde a las aventuras en el pupilaje del dómine Cabra. Está formado por la descripción de Cabra, las primeras comidas, la simulación de la enfermedad por don Diego y Pablos, la muerte del pupilo extranjero y el rescate y recuperación de los estragos sufridos con los preparativos para el viaje a Alcalá. Tiene una extensión total del $57,71 \%$ (3119 palabras), siendo el bloque temático más extenso.

d) El cuarto bloque temático se desarrolla en Alcalá, en el que se omiten las aventuras de Pablos y se centra en la carta del tío de Pablos, Alonso Ramplón, y la contestación del sobrino en otra carta en la que manifiesta que desea seguir sus pasos y convertirse en otro hombre de provecho como él, servidor del rey. Este apartado presenta una 
extensión total del 27,98\% (1512 palabras) y se aleja totalmente de la línea argumental del Buscón quevediano.

Se trata, por tanto, de una traducción de los primeros capítulos del Buscón, presentando un final abrupto en el que Pablos redacta una carta en la que promete seguir sus pasos y contarle a su tío más aventuras, pasaje este último que no he encontrado ni en la traducción inglesa de 1657, ni en la versión francesa de 1633. Si comparamos esta traducción con la edición crítica de la versión $\mathrm{Z}$ del Buscón, nos daremos cuenta de que esta extraña traducción de 1683 se centra en el libro primero y en los capítulos 1 ("En que se cuenta quién es y de dónde"), 2 ("De cómo fui a la escuela y lo que en ella me sucedió”), 3 ("De cómo fui a un pupilaje por criado de don Diego Coronel”), los tres primeros párrafos del capítulo 4 ("De la convalecencia y ida a estudiar a Alcalá de Henares") y 7 ("De la ida de don Diego y nuevas de la muerte de mis padres, y la resolución que tomé en mis cosas para adelante") en el comienzo del capítulo con la carta que le envía el tío a Pablos.

Uno de los problemas al que nos enfrentamos es saber qué edición se toma como modelo. El título del libro manifiesta claramente "Translated from Spanish", pero no todos los críticos están de acuerdo. Frente a la traducción príncipe inglesa de 1657 realizada por John Davies que toma como modelo la francesa de 1633, Astrana Marín cree que esta traducción sigue un modelo español, aunque no especifica la versión del Buscón que sigue el texto inglés:

Tanto la novela de Céspedes como la de Quevedo, aunque vertidas directamente del castellano, sufren profundas alteraciones y supresiones (Astrana 1946: 794)

De la misma opinión es Thomas, quien se explica en semejantes términos:

Such a change of names would ordinarily create the suspicion that this version was but a rechauffe of an existing English translation. The Pleasant Story of Paul of Segovia, however, does not confirm that suspicion. The existing French and English versions of this story had already changed the names and some of the incidents of the Spanish original; the new translator, who signs himself W.B., returns to the original, which is all the more surprising as he is only reproducing the story in an abridged and fragmentary form. He only utilises the first twelve chapters, coming to an abrupt conclusion with the letter written by the hero to his uncle, the Hangman of Segovia (Thomas 1933: 286-287) 
La duda de la procedencia de esta traducción aparece en las palabras de Navarro Errasti que explica lo siguiente:

Se trata, más que de una traducción, de un resumen, por lo que es difícil afirmar si su autor utilizó la versión francesa o el original español, o, incluso, la otra traducción inglesa. Astrana Marín insiste en que es una traducción directa del español. Sin embargo, hemos podido constatar que la decisión de Astrana es un tanto gratuita. El libro contiene asimismo On the Qualities of a Marriage, que es la versión inglesa de Cartas de las calidades de un casamiento. El traductor, del que sólo se sabe que es pariente de Lady Henriette Grenville, no ha podido ser identificado. No se conocen reimpresiones de esta obra. (Navarro Errasti 1987b: 177)

Admitiendo con esta autora que este Buscón inglés de 1683 es un tanto particular, su postura nos obliga a realizar un pequeño cotejo teniendo en cuenta por un lado la edición crítica de la versión $\mathrm{Z}^{4} \mathrm{y}$ por otro lado la traducción príncipe inglesa de 1657, que revela que The pleasant story of Paul of Segovia de 1683 no toma como modelo la anterior traducción inglesa, sino el original castellano.

Analizo, en primer lugar, los nombres de los personajes:

My Fathers Name was Ysidore, Native of the same City and by Trade a Barber (1657: 1)

I am of Sigovia, my Fathers Name is Clement Paul, a Native of the City; (Heaven take his Soul) (1683: 66)

Yo, señor, soy de Segovia. Mi padre se llamó Clemente Pablo, natural del mismo pueblo. Dios le tenga en el cielo (Z: 219).

His wife, who as I believe, was my mother, was called Roguille. It was the opinion of most of the Neighbourhood, that she was of the race of the Jews (1657: 1) he married Aldonce Saturna of Revola who had the reputation not to be the best Christian of that Country (1683: 66)

Estuvo casada con Aldonza de Saturno de Rebollo [...]. Sospechábase en el pueblo que no era cristiana vieja (Z:219)

4 Rey, 2003: 37: “Todas las ediciones del Buscón de los siglos XVII y XVIII derivan de la impresa en Zaragoza en $1626(\mathrm{Z})$, bien directamente, bien a través de Z2 (Zaragoza 1626 [en realidad, Sevilla]) o de Z3 (Zaragoza 1628). Algunos estudiosos afirman que hubo una extensa difusión manuscrita, pero como esta no dejó ninguna huella nada es posible decir sobre la misma. Los manuscritos que hoy conocemos del Buscón (designados con las siglas S, C y B) solo han sido tenidos en cuenta por los investigadores del siglo XX. Sus lecturas privativas no pasaron a las ediciones impresas durante aquellos siglos". 
I began from that time, to keep company with those who were bigger then my self, insomuch that I become intimate with a Cavaliers son of the City, whose name was Don Alonso de Sougniga (1657: 9).

I was early put to School, where I contrasted friendship with the son of Don Alonso Coronello, a person of quality (1683: 67).

Llegábame, de todos, a los hijos de los caballeros, y particularmente a un hijo de don Alonso Coronel de Zúñiga (Z: 221).

Now it so fell out upon a day just after the Christmas Holy-dayes, that we going together to school, met with one wjose name was Ponce d'Aguire, a rag of the Law, who was not very well in his wits: Let us call yon fellow Ponce Pilate, quoth little Diego, and the run away (1657: 13)

One day as was walking the Street with my friend Don Diego Coronello, we met a man named Pontius Dagura, a man of publick employ; Don Diego bid me call him Pontius Pilate, which I did (1683: 68)

Sucedió, pues, que uno de los primeros que hubo escuela por Navidad, que, viniendo por la calle un hombre que se llamaba Poncio de Aguirre, el cual tenía fama de consejero, que el don Diaguito me dijo:

- Hola, llámale Poncio Pilato y echa a correr.

Yo, por darle gusto a mi amigo, llamele Poncio Pilatos (Z: 222)

He was at last inform'd of one Ragot, who used to teach Gentlemens children (1657: 21)

His Father soon after that took a resolution to place his son Pensioner, with a Graduate named Cabra, who in his House had the Tuition of some young Gentlemen of Quality (1683: 73)

Supo que había en Segovia un licenciado Cabra que tenía por oficio criar hijos de caballeros (1683: 225)

thereupon he provided a steward to oversee Don Diego's expences, him he furnish'd with Bills of exchange (1657: 39)

Alonso allotted his Son a Steward, whose name was Aranda, to govern his Affairs, with a Bill of Exchange on a Merchant called Julian Merluche, and accordingly we took Coach (1683: 104)

$\mathrm{Y}$ con esto diole un criado para mayordomo, que le gobernase la casa y le tuviese cuenta del dinero del gasto, que nos daba remitido en cédulas para un hombre que se llamaba Julián Merluza [...], del mayordomo, que se llamaba Aranda (Z: 231)

La traducción inglesa de 1657 cambia por sistema todos los nombres siguiendo la traducción francesa de 1633. El padre del Buscón, Clemente 
Pablo se convierte en Ysidore haciendo un chiste con el nombre ${ }^{5}$, la madre Aldonza de Saturno de Rebollo se llama Roguille, y así ocurre con el resto de personajes como se ha podido apreciar.

Pero encontramos además otros cambios muy interesantes de la traducción de 1657 que contrastan con los de la obra de 1683, quien sigue el original castellano, especialmente en las omisiones:

his hair red, from which colour God deliver us (1657: 21)

little head, covered with red hair; and it is sufficient to say according to the Proverb, no good Cats or Dogs that are red $(74)$

su cabeza pequeña, pelo bermejo (no hay más que decir para quien sabe el refrán que dice "ni gato ni perro de aquella color" (Z: 225)

his Hand like a Skeleton, if he stirred never so little, all his bones ratled within him (1657: 22)

his Hands as shrivled Loppings of Vines, viewing him from the Wast downwards: He seemed like a Fork or Compass, so long and magre did his Thighs appear when he moved (1683, pp. 75-76)

las manos como un manojo de sarmientos cada una. Mirado de media abajo, parecía tenedor o compás, con dos piernas largas y flacas (Z: 225)

He was an arch Villian and a miserable Hound (1657: 23)

In fine, one may call him the Protype of Poverty and Misery (1683: 78)

Al fin, era archipobre y protomiseria (Z: 224)

Referencia al Diaquilón: omite 1657

This I protest began much to afflict me, and much the more when I certainly perceived, that such as had for some time been in this House had Complexions which looked as if daubed with Diachilon (1683: 79)

Yo, con esto, me comencé a afligir, y más me asusté cuando advertí que todos los que antes vivían en el pupilaje estaban como leznas, con unas caras que parecían se afeitaban con diaquilón (Z: 226)

Maldición de Pablos en la comida: omite 1657

May the Devil confound thee with all thou hast eaten said I, thee who makest so cruel Threats to my Bowels (1683: 82)

¡Mal te haga Dios y lo que has comido, lacerado -decía yo-, que tal amenaza has hecho a mis tripas (Z: 226)

$5 \quad$ Ssidore con $Y$ para hacer el siguiente chiste: "for some of our Neighbours tongues were to lavish as to report, that she had changed the Roman I of my Fathers name into a Greek Y" (1657: 1-2).

6 Variante interesante porque la versión B la retira siguiendo las críticas del Memorial y el Tribunal. Ver Rey 2003: 60 . 
Misas en altar privilegiado: omite 1657

this cannot be done, if some charitable [89] persons do not recite for us extraordinary Prayers of Jubile, and cause Masses to be said for us on some priviledg'd Altar (1683, pp. 88-89)

si alguno no nos reza en alguna cuenta de perdones y nos saca de penas con alguna misa en altar privilegiado (Z:228)

Consecuencias del hambre: omite 1657: I found my doublet and hose a great deal to big for me, I began to suspect some one had changed my clothes (1657: 30)

Fear had made me leaner in one day than others in fifteen, My Shoulders and my Stomach did already swim in my Doublet; my Legs had need of seven pair of Stockins; my Teeth were become of an Orange colour (the true colour of despair). He made me read the first Lesson to the others, and my hunger was so great, that I broke my Fast in eating half of the words (1686, pp. 89-90)

Ya mis espaldas e ijadas nadaban en el jubón, y las piernas daban lugar a otras siete calzas; los dientes sacaban con tobas, amarillos vestidos de desesperación. Mandáronme leer el primer nominativo a los otros, y era de manera mi hambre que me desayuné con la mitad de las razones, comiéndomelas (Z: 228)

Tocino en la olla: omite 1657.

Cabra at length heard that there were many murmurings in the City against him, for the bad chear he made us, resolved it should be better, and to that end he got a Box made of tin, full of holes, in with he put a little Bacon, and having fastened a little string to it, he let it hang a little while in the Pot, but finding that it was too expensive, he believed it to be sufficient only to shew it the Bacon without putting it in (1683: 91)

solo añadió, a la comida, tocino en la olla por no sé qué le dijeron un día de hidalguía allá afuera. Y así, tenía una caja de hierro toda agujereada como salvadera, abríala y metía un pedazo de tocino en ella que la llenase, y tornábala a cerrar y metíala colgando de un cordel en la olla para que le diese algún zumo por los agujeros y quedase para otro día el tocino. Pareciole que en esto se gastaba mucho y dio en asomar el tocino en la olla ( $\mathrm{Z}: 228)$.

Criado echado por las migas en la ropilla: omite 1657

He made his old Aunt the Governess of the Family, and to dress our provision for us, and to serve his Pensioners; and turned away his man, because on a Friday he perceived some few Crumbs of Bred to me on his Clothes (1683: 95) Metió en la casa la vieja por ama para que guisase y sirviese a los pupilos, y despidió al criado porque le halló el viernes a la mañana, con unas migajas de pan en la ropilla ( $\mathrm{Z}: 229)$ 
Padres del yermo: omite 1657:

and at four dayes end we sate up in our beds, yet all this while, we did but look like shadows in respect of others (1657, pp. 37-38)

At the end of four daies we arose, but looked like the shadows of other men; and so yellow and magre we were, that once we were taken to be the Offspring of the Fathers of the Desert (1683: 102)

Levantábamos a hacer pinicos dentro de cuatro días y aún parecíamos sombras de otros hombres y, en lo amarillo y flaco, simiente de los padres del yermo (Z: 231)

La traducción de 1657 omite pasajes que contienen referencias a elementos religiosos. Sin embargo, la traducción de 1683 demuestra seguir a la versión castellana $\mathrm{Z}$ incluyéndolas. Como se puede comprobar, la traducción 1683, a pesar de su brevedad, sigue con bastante exactitud estos pasajes

No quiero tampoco extenderme mucho más en proporcionar ejemplos, pero algunos son muy interesantes y no me resisto a citarlos:

I so fell out that next morn, whilest we were saying the Creed, and our other prayers (1657: 14)

This made so dreadful an impression on my spirits, that the day following, I being called to say my Prayers (1683: 69)

Mandáronme el día siguiente decir, como solía, las oraciones a los otros, llegando al Credo (Z: 222)

my Master intended to give some recreation to his schollars, resolve to make a Royalty. The cake was divided and the Kingdom of the Bean came to my share without any artifice (1657: 14). (Es la tradición del pastel horneado con una alubia dentro con lo que el que la descubre se convierte en el rey de la noche). It happened not long after (the Time of Carnival) a King of the Schollars was to be made; (a pleasant custom in those Parts) and the Lot fell on me (1683, pp. 69-70)

Echamos suertes entre doce señalados por él, y cúpome a mí (Z: 222)

my hunger-starv'd Horse, fell upon a Basket of Coleworts and forthwith devoured them, stuffing his Guts, and not a little overjoy with so pleasant a bait (1657: 16)

my Horse being almost famished, greedily seized on a Cabbage, and almost made but one swallow of it (1683: 71)

agarró mi caballo un repollo a una, y ni fue visto ni oído cuando lo despachó a las tripas (Z: 223) 
Amidst this scufle, my Companions armed by this, in their Kings defense, broke two of the herb-women necks (1657: 17)

my Comrades in the mean time with stones repulsed the Fruiterers, and wounded two of them in the head (1683: 72)

Ya mis muchachos se había armado de piedras y daban tras las verdureras, $y$ escalabraron dos (Z: 223)

In came the Officers, who seized upon the Herb-women, and such scholars and arms, as they could catch; for my subjects had made use of their weapons in an offensive way, which they intended only for shrew as Daggers, Swords and Spears (1657: 17).

at length the Officers of Justice came and seized some of them and some of the Scholars, and disarmed them for they had Swords and Poniards as the Kings Guards (1683: 72)

Vino la justicia, prendió a berceras y muchachos, mirando a todos que armas tenían y quitándoselas, poque habían sacado algunas dagas de las que traían por gala, y otros, espadas pequeñas (Z: 223)

his nose like a saddle, you would have imagined, someone had broken the bridge of it with a clap (1657: 21)

his Nose half eaten by Scurf, which came not to pass through Debauchery because that would cost money (1683: 74)

la nariz, entre Roma y Francia, porque se le había comido de unas búas de resfriado, que aún no fueran de vicio porque cuestan dinero $(\mathrm{Z}: 225)$

his throat was as long as a Cranes (1657: 22)

His Throat was as long as an Austritchs; the Apple whereof seemed so large as if necessity had forced it out to see for Victual (1683: 75)

el gaznate, largo como avestruz, con una nuez tan salida que parecía se iba a buscar de comer forzada por la necesidad (Z: 225)

if he stirred never so little, all his bones ratled within him (1657:22)

His Bones refounded like the Ivory Clickets of a Leopard, which they use to give People notice to avoid them (1683: 76)

le sonaban los huesos como tablillas de san Lázaro (Z: 224)

he wore a cap which the rats had all beeaten, for the Grease sake (1657:22)

He wore in Summer a Bonnet which was nibled by Mice, which heretofore might be Cloth, and was lined with the sweaty Greece which fell from his Head (1683: 76)

Traía un bonete los días de sol, ratonado con mil gateras y guarniciones de grasa (Z: 225) 
everyone would have taken him for a Scar-crow (1657, pp. 22-23)

his long Hair that covered his Vest (as narrow and short as it was) made him look like a true Lacquey of Death (1683: 77)

Parecía, con los cabellos largos y la sotana mísera y corta, lacayuelo de la muerte (Z: 225)

an being older then some, and stronger then others, I began to lay about me with both my hands, and that so simbly, that in three or four mouth-fulls I had consumed above half of what our Master had left upon the table (1657:27)

but being lately better fed, and stronger than the others, I pull'd the Dish to me, which all had seiz'd on, and of three morsels I swallowed two, which made them grumble (1683: 83)

como más sano y fuerte que los otros, arremetí al plato, como arremetieron todos, y emboqueme de tres mendrugos los dos y el un pellejo. Comenzaron los otros a gruñir ( $\mathrm{Z}: 227)$

He sent to hire a coach for us (1657:35)

then he got us carried from thence in a Chair (1683:99)

Nos mandó llevar en dos sillas a casa (Z: 230)

There were Oculists sent for, to search out our eyes, for they were sunk into our heads, that we stood in need of a wormer to scrue them up again (1657:36)

Spies were sent for to pry into what part of our faces our Eyes were hid (1683: 100)

Trujeron exploradores que nos buscasen los ojos por toda la cara (Z: 231)

En el episodio de Rey de carnaval, Pablo explica, en la versión Z, que su caballo engulle un "repollo" que va dando vueltas hasta que acaba en las tripas. La traducción de 1683 utiliza el término a cabbage, que es mucho más cercano al original que la expresión en plural utilizada por la traducción de 1657: "a Basket of Coleworts"; en la descripción del dómine Cabra hay elementos muy interesantes: la traducción de 1657 explicita que Cabra tiene la nariz rota, aspecto que el original español no afirma sino que estaba comida "de unas búas de resfriado", elemento que sigue fielmente 1683: "his Nose half eaten by Scurf”. La traducción de 1657 explica que Cabra es un espantapájaros: "scar-crow". Pero este no es el término que utiliza el modelo castellano que lo define como lacayuelo de la muerte, término que intenta buscar la obra de 1683 en "a true Lacquey of Death"

Hay algunos casos en los que la composición de 1683 se aleja de la versión de Z: 
away ran I to Don Diego, who was newly come home with a cut in his head, which he receiv'd in the fray, which made his Father and Mother conclude not to send him any more to School (1657 p. 18)

I returned to Don Alonso Coronello with his Son, who was preserved in the Battle (1683: 73)

salime de casa y fuime a ver a mi amigo don Diego, al cual hallé en la suya descalabrado, y a sus padre resueltos por ello de no le inviar más a la escuela (Z: 223)

Por ejemplo, $\mathrm{Z}$ explica que tras la batalla nabal, don Diego es "descalabrado", lo que hace que su padre tome la decisión de quitarlo de la escuela y llevarlo al pupilaje de Cabra. En este caso la traducción de 1683 afirma que don Diego salió ileso, lo que produce cierta incoherencia porque no explica el motivo por el que don Alonso saca a su hijo de la escuela.

\subsection{On the qualities of a Marriage}

Corresponde esta parte de la traducción a la Carta de las cualidades de un casamiento. Ocupa las páginas 123 a la 140 y presenta un total de 1432 palabras que vienen a ser tres páginas de un libro normal.

Una rápida comparación con la edición realizada por Celsa Carmen García Valdés ${ }^{7}$ muestra que la carta traducida omite ciertos pasajes: en primer lugar, el párrafo inicial, ciertamente erudito, que se centra en una glosa de los Proverbios, 30, 10: “La mujer fuerte ¿quién la hallará?”. Más adelante, al final de la carta omite dos pasajes: el primero se refiere a la mujer de mala condición ('de mal genio') y el pasaje en el que se menciona a la dueña, probablemente por la dificultad en la traducción de este fragmento.

Otro cambio insignificante es que la traducción de 1683 intercambia la posición de dos párrafos en la que el autor se describe a sí mismo como "cojo" y el siguiente en la que se define como persona "no aborrecible ni enfadosa".

En principio, observamos la misma técnica que en la traducción del Buscón. El traductor busca la precisión y sigue con bastante acierto el original. En algunos momentos, parece querer puntualizar, aclarar o esclarecer algunos elementos del modelo, quizá para acercar las circunstancias propias del texto a los lectores ingleses. Así, por ejemplo, cuando el texto explicita que le da igual las mujeres altas o bajas ya que hay chapines, la traducción hace un inciso aclaratorio:

\footnotetext{
Ver “Carta de las cualidades de un casamiento”, García Valdés, (ed.): 460-467.
} 
Chiopins or Stilts (much used in Spain and Italy). (On the qualities. 134)

O cuando se explica que es más deseable la mujer flaca que la gorda ("más la quiero alma en cañuto u pellejo en pie, que doña Mucha o cuba en zancos" ${ }^{8}$ ), la traducción que analizo se desvía con una expresión inglesa:

would be more acceptable to my Fancy, to be rather slender as a Cow than gross as a Tun (On the qualities: 135 ).

Lo mismo ocurre cuando se rechaza la posibilidad de las dueñas, donde la traducción no parece muy segura de haber acertado con el término escogido "Governess" y matiza al lado añadiendo el término "Duegna”.

\section{Conclusiones}

Nos encontramos, me parece, con un libro muy interesante que presenta una traducción de una novela de Gonzalo de Céspedes y Meneses y dos obras de Quevedo: el Buscón y la Carta de las cualidades de un casamiento. En general, podemos apreciar que el traductor sigue con bastante precisión los originales castellanos.

En el caso del Buscón, creo que el término "resumen", utilizado por Navarro Errasti, no es adecuado para describirlo. No se trata de una sinopsis de toda la acción, sino que encontramos una traducción bastante precisa de los primeros capítulos de este libro. Es posible que fuese el inicio, el borrador de una traducción más extensa que después, por cansancio o por razones que no alcanzo, se haya abandonado. Pero desde luego, creo que hay que descartar la idea de que esta traducción tenga algo que ver con la traducción príncipe inglesa de 1657, su reedición en 1670, o la francesa de 1633.

En definitiva, es posible que el autor aprovechase en 1683 la fama que tenía don Francisco en Inglaterra tal y como afirma Arbesú. De cualquier forma, de lo que sí estamos seguros es que el traductor, W.B., quien quiera que fuese, conocía lo suficiente de la lengua castellana y era un enamorado de la obra de Quevedo.

En cualquier caso, sorprende la poca atención de la crítica, lo que nos advierte de la cantidad de trabajo que nos queda por realizar en este apasionante mundo de las relaciones interculturales de dos países y dos idiomas.

8 “Carta de las cualidades de un casamiento” García Valdés, (ed.): 465. 


\section{Bibliografía}

ASTRANA MARÍN, Luis (1946). Epistolario completo de don Francisco de Quevedo-Villegas. Madrid: Instituto Editorial Reus.

ARBESÚ, David (2006). “La manipulación ideológica de las obras de Quevedo en la Inglaterra del siglo XVII”, La Perinola, 10, 317-338.

BARKER, John William (1945). "Notas sobre la influencia de Quevedo en la literatura inglesa”. Boletín de la Biblioteca Menéndez Pelayo, 21, 429-435.

CHAMOSA, José Luis (1987). "Bartholomew Yong: la traducción inglesa de las Dianas", in Julio César Santoyo, and Isabel Verdaguer, (ed.), De clásicos y traducciones: versiones inglesas de clásicos españoles (s. XVI-XVII). Barcelona: Promociones y Publicaciones Universitarias, 59-79.

CUNCHILLOS, Carmelo (1987). “Traducciones inglesas del Quijote (1612-1800)”, in Julio César Santoyo, and Isabel Verdaguer, (ed.), De clásicos y traducciones: versiones inglesas de clásicos españoles (s. XVI-XVII). Barcelona: Promociones y Publicaciones Universitarias, 89-113.

GUARDIA MASSÓ, Pedro (1987). The Spanish Bawd, Londres, 1631”, in Julio César Santoyo, and Isabel Verdaguer, (ed.), De clásicos y traducciones: versiones inglesas de clásicos españoles (s. XVI-XVII).Barcelona: Promociones y Publicaciones Universitarias, 129146.

JAURALDE POU, Pablo (1999). Francisco de Quevedo (1580-1645). Madrid: Castalia.

LUTTIKHUIZEN, Frances (1987). “Traducciones inglesas de las Novelas ejemplares”, in Julio César Santoyo, and Isabel Verdaguer, (ed.), De clásicos y traducciones: versiones inglesas de clásicos españoles (s. XVI-XVII). Barcelona: Promociones y Publicaciones Universitarias, 147-164.

MARTINENGO, Alessandro, Diego Símini (2003). "La primera traducción italiana del Buscón" in Alfonso Rey (ed.), Estudios sobre el Buscón. Pamplona: Eunsa, 273-294.

NAVARRO ERRASTI, María Pilar (1980). “Inglaterra y Quevedo”, Letras de Deusto, 20, 149-166.

NAVARRO ERRASTI, María Pilar (1987a). “J. D. Primer traductor inglés del Buscón, reconstrucción de su biografía a través de los prefacios de sus traducciones”, Miscelánea: A journal of English and American Studies, 8, 33-60.

NAVARRO ERRASTI, María Pilar (1987b). “Quevedo en lengua inglesa”, in Julio César Santoyo, and Isabel Verdaguer, (ed.), De clásicos y traducciones: versiones inglesas de clásicos españoles (s. XVI-XVII). Barcelona: Promociones y Publicaciones Universitarias, 165188.

QUEVEDO, Francisco (1993). "Carta de las cualidades de un casamiento. A doña Inés de Zúñiga y Fonseca, condesa de Olivares”, in Celsa Carmen García Valdés (ed.), Prosa festiva completa. Madrid: Cátedra, 460-467. 
QUEVEDO, Francisco (1657). The life and adventures of Buscon. The witty Spaniard. Put into English by a Person of Honour. To which is added The provident Knight. By Don Francisco de Quevedo, A Spanish Cavalier. London: Printed by J. M. for Henry Herringman.

QUEVEDO, Francisco (2007). El Buscón. Edición crítica de las cuatro versiones. La del Buscavidas, por otro nombre don Pablos. La vida del Buscón, llamado don Pablos. Historia de la vida del Buscón, llamado don Pablos, ejemplo de vagamundos y espejo de tacaños (versiones $Z$ y B). Alfonso Rey (ed.), Madrid: C.S.I.C.

REY, Alfonso (2003). "El texto del Buscón”, in Alfonso Rey (ed.), Estudios sobre el Buscón, Pamplona: Eunsa, 37-64.

ROIG Miranda, Marie (2003). “Las traducciones francesas del Buscón”, in Alfonso Rey (ed.), Estudios sobre el Buscón, Pamplona: Eunsa, 243-272.

SANTOYO, Julio César (1987). "El Lazarillo en Inglaterra: primera traducción (1568), primera edición (1576)”, in Julio César Santoyo, and Isabel Verdaguer, (ed.), De clásicos y traducciones: versiones inglesas de clásicos españoles (s. XVI-XVII). Barcelona: Promociones y Publicaciones Universitarias, 7-24.

W. B. (1683). The Famous History of Auristella, Originally Written by don Gonsalo de Cespedes. Together with the Pleasant Story of Paul of Segovia, by Don Francisco de Quevedo. Translated from Spanish. London: Joseph Hindmarsh. Bookseller to his Royal Highness, at the Black Bull in Cornhill.

THOMAS, Henry (1933). “The English Translations of Quevedo’s La vida del Buscón”, Revue Hispanique, 81, 282-299.

VERDAGUER CLAVERA, Isabel (1987). “Traducciones inglesas del Guzmán de Alfarache”, in Julio César Santoyo, and Isabel Verdaguer, (ed.), De clásicos y traducciones: versiones inglesas de clásicos españoles (s. XVI-XVII). Barcelona: Promociones y Publicaciones Universitarias, $115-128$. 


\section{“iQué amables tus moradas...” (Salmo 84 [Vg 83]), de fray Pedro Malón de Echaide, y el modelo de fray Luis de León para la paráfrasis de los salmos bíblicos ${ }^{1}$ "¡Qué amables tus moradas..." (Psalm 84 [Vg 83]), by fray Pedro Malón de Echaide, and fray Luis de León’s model for biblical psalms translation}

\section{CARlos Mata Induráin}

Universidad de Navarra - GRISO

cmatain@unav.es

Texto recebido em / Text submitted on: 15.09.2015

Texto aprovado em / Text approved on: 12.10.2015

Resumen: En este artículo pretendo analizar una de las paráfrasis bíblicas contenidas en $\mathrm{La}$ conversión de la Madalena (Barcelona, Hubert Gotard, 1588), de fray Pedro Malón de Echaide. En la prosa de su tratado ascético el escritor agustino intercala una serie de poemas, la mayoría de los cuales son traducciones o, mejor dicho, paráfrasis exegéticas de distintos salmos bíblicos, en las cuales sigue como modelo las realizadas por su maestro fray Luis de León. Mi comentario se centra en el poema que comienza “iQué amables tus moradas...", localizado en la "Parte primera del tratado de la Madalena”, $\$ 1$, que es paráfrasis del Salmo 84 (Vulgata 83), "Quam dilecta tabernacula tua, Domine virtutum”. Ofrezco una versión anotada del texto y comento su contenido y estructura, así como la técnica de la amplificatio utilizada por Malón de Echaide en su redacción y los principales recursos retóricos empleados.

Palabras clave: Pedro Malón de Echaide. Paráfrasis bíblicas. Traducción. Salmos. Literatura española del Siglo de Oro.

Abstract: In this paper I propose an analysis of the biblical paraphrases included in $\mathrm{La}$ conversión de la Madalena (Barcelona, Hubert Gotard, 1588), by fray Pedro Malón de Echaide. In this ascetic treatise the Augustinian writer inserts several poems, most of them translations or, rather, exegetical paraphrases of different biblical Psalms, following the model of fray Luis de León. My commentary focuses on the poem that begins " $i Q u e ́$ amables tus moradas...", placed in the "Parte primera del tratado de la Madalena”, $\$ 1$, a parafrase of Psalm 84 (Vulgata 83), "Quam dilecta tabernacula tua, Domine virtutum". I offer an annotated version of the text and analyse its content and structure, as well as

1 Este trabajo forma parte del proyecto de investigación Modelos de vida y cultura en la Navarra de la modernidad temprana, dirigido por Ignacio Arellano, que cuenta con una ayuda de la Fundación Caja Navarra, "Convocatoria de ayudas para la promoción de la Investigación y el Desarrollo 2015", Área de Ciencias Humanas y Sociales. 
the amplificatio technique used by Malón de Echaide in his translation and the main rhetorical devices.

Key words: Pedro Malón de Echaide. Biblical paraphrases. Translation. Psalms. Spanish Golden Age Literature.

Como apretado resumen de la figura y la obra de fray Pedro Malón de Echaide $^{2}$, me limitaré a copiar aquí las palabras con que lo presentaba en un trabajo anterior:

Pedro Malón de Echaide (Cascante, 1530-Barcelona, 1589) profesó como religioso en el convento agustino de Salamanca el 27 de octubre de 1557. En la universitaria ciudad castellana enseñaban, entre otros, maestros destacados como fray Luis de León, Domingo de Soto, Pedro de Sotomayor, Juan de la Peña o Gaspar de Grajal, a cuyos cursos Malón asistiría como alumno, recibiendo una amplia formación humanista, filosófica y teológica. Más tarde desempeñó varios cargos dentro de su orden, con distintos destinos, en especial en el reino de Aragón. Un año antes de su muerte había publicado la única obra suya que conservamos, y por la que sin duda merece un lugar entre los clásicos de nuestra literatura áurea: La conversión de la Magdalena, en que se ponen los tres estados que tuvo, de pecadora, de penitente y de gracia (Barcelona, Hubert Gotard, 1588). La lectura de su obra nos revela al escritor agustino como teólogo originalísimo y excepcional escritor, y como uno de los más brillantes espíritus humanistas del momento. La conversión de la Magdalena no es tan sólo, como se ha pensado a veces, una paráfrasis de los Evangelios, sino un rico mosaico que, tomando la figura de la Magdalena como símbolo del penitente, amalgama los más diversos temas sociales, teológicos, históricos y lingüísticos, todo perfectamente conjuntado por la mentalidad de un humanista ascético. En el tratado -que gozó de gran éxito y difusión durante los siglos XVI y XVII, como demuestran las numerosas ediciones y su pronta traducción a otros idiomas- se aúnan las más diversas corrientes renacentistas: Platón, Plotino y San Agustín se encuentran magníficamente armonizados junto a los neoplatónicos italianos, sobre todo Ficino y Pico della Mirandola (Mata Induráin 2005: 116 $6^{3}$.

Recordaba también que, al medio de la exuberante prosa de su tratado, y a modo de descanso de su lectura, Malón intercaló diversas composicio-

2 Sobre el autor y su obra ver especialmente Aladro Font 1998, y una buena síntesis en la introducción de Arellano, Aladro y Mata Induráin a su reciente edición de La conversión de la Madalena (2014), con una completa bibliografía (73-85). Sobre la orden agustina y sus escritores en el Siglo de Oro, ver, entre otros trabajos, Monasterio 1929 y Álvarez 1978.

3 En ese artículo se ofrece el comentario de otra composición maloniana, "Como la cierva en medio del estío..." (paráfrasis del salmo 42-43 [Vg 41-42]). 
nes poéticas. La función de los versos no era otra que facilitar la asimilación por parte del lector de la enseñanza contenida en la prosa, de acuerdo con el conocido tópico horaciano del delectare et prodesse. El propio escritor se encarga de explicar que ha incluido esos poemas

porque, como ya he dicho en el prólogo, están los gustos tan estragados con los muchos vicios, que para que [los lectores] puedan comer algo que les sea de provecho es menester dárseles guisado con mil salsillas, y aun plega a Dios que de esta suerte lo detengan y no lo vomiten como comida indigesta. $Y$ no sé si me engaño, pero pienso que con los versos se desempalagarán para tragar mejor la prosa ${ }^{4}$.

En fin, Arellano, Aladro y Mata Induráin escriben a propósito del prólogo maloniano a su tratado:

Asimismo, advierte el autor que para "desempalagar el gusto cansado de la prosa he encajado cosillas de verso, porque, aunque no es curioso, haga la variedad del estilo lo que había de hacer la bondad de la poesía" (p. 100). Malón se respalda en el hecho de que los Salmos, el Libro de Job, el Cantar de los cantares, etc., al estar insertos en la Biblia son palabra de Dios. Si Dios había escogido la poesía para comunicarse con los hombres, zquién se atrevería a menospreciar el arte poético? Así y todo, y para evitar posibles críticas, Malón echa mano de varios ejemplos de ilustres varones que recurrieron al mismo procedimiento, desde David, que "tantos sonetos y canciones compuso y cantó a la arpa divina, en alabanza del gran Gobernador del universo" (p. 100), hasta el "excelentísimo dotor San Tomás de Aquino", a quien "poco le embarazó para ser santo y supremo teólogo por haber hecho los hinos y prosa que se cantan al Santísimo Sacramento" (p. 102) (Malón de Echaide 2014: 36).

\section{Fray Luis de León, modelo para la paráfrasis de los Salmos}

Ya Marcelino Menéndez Pelayo, en el volumen III de su Biblioteca de traductores españoles, había sentenciado:

Era Malón poeta elegantísimo, clásico en las formas aun al tratar asuntos sagrados, uno en fin de los que con manos cristianas labraban el mármol de la antigüedad, y ora fuese por la razón que él expone y veremos en seguida,

4 Fray Pedro Malón de Echaide, La conversión de la Madalena (2014). Ed. de Ignacio Arellano, Jordi Aladro y Carlos Mata Induráin. New York: IDEA, 339-340. Todas las citas serán por esta reciente edición. 
ora por el natural deseo de dar a conocer sus versos que tenía sin duda (y con razón) en mucha estima, juzgó conveniente mezclarlos en el ameno tejido de su obra. Manifiéstase en el prólogo a los lectores grande enemigo de la poesía profana simbolizada para él en Garcilaso y sus secuaces, aunque él con frecuencia los imita (Menéndez Pelayo 1953: $8^{5}$ ).

Para añadir poco después que "Los versos publicados con La Magdalena son excelentísimos” (Menéndez Pelayo 1953: 8), matizando, eso sí, que Malón es "menos sobrio y conciso, es verdad, pero no menos inspirado que Fr. Luis de León” (Menéndez Pelayo 1953: 9). Ciertamente, fray Luis, que fue su maestro en Salamanca, es el verdadero modelo para sus paráfrasis bíblicas. Ya el también agustino Juan de Soto, en el "Prólogo al lector" de su Exposición parafrástica del Psalterio de David en diferente género de verso español, con exposiciones varias de varios y gravísimos autores (Alcalá, por Luis Martínez Grande, 1612), explicaba:

La misma razón que movió a algunos a componer los salmos en verso, aunque pocos, como al doctísimo Padre fray Luis de León, al Padre Maestro fray Pedro Malón, al Padre Maestro fray Alonso de Mendoza y al Padre Maestro fray Jerónimo Cantón, todos religiosos gravísimos de mi orden, y otros de otras y diferentes estados, que por mi cuenta deben de ser hasta treinta los que andan esparcidos en libros y de mano, esa misma me movió a mí a componerlos todos ciento y cincuenta. Y si bien la he considerado, es ver que el Real Profeta y los demás autores de salmos los compusieron en verso $[. .$.$] no parece fuera$ de propósito que se expongan y declaren en verso, tal que todos le entiendan, conozcan y sepan (citado por San José Lera 2006: 40-41 ${ }^{6}$ ).

\section{Por su parte, Cristóbal Cuevas señala:}

Un poeta-humanista como el Mtro. León, que además era fraile y teólogo, había de estimar en mucho su entrega a la traducción de textos bíblicos, clásicos o romances -éstos, con tal de ser prestigiosos-. Ello le permitía mostrarse filólogo capaz de ejercer de fidus interpres, poeta que trasvasa las bellezas de pensamiento y forma de los originales, y hasta exegeta cristiano -la traducción había de responder al sentir de la Iglesia, sin dar pie a interpretaciones heterodoxas (Cuevas García 2001: 27).

5 Sobre la traducción de los Salmos en el Siglo de Oro, ver Alonso Schökel y Zurro 1983, y Kaplis-Hohwald 2003. Para la presencia del Salterio de David en la cultura española, ver Fernández de Castro y Álvarez 1928. Sobre fray Luis de León, Cuevas García 1982 y Alcántara Mejía 2002.

6 Para las paráfrasis bíblicas de los Salmos realizadas por fray Luis, ver también San José Lera 2003 y 2010 . 
Valentín Núñez Rivera, en un trabajo dedicado a la relación entre salmos y oda en el Siglo de Oro, escribe:

Al margen de los salmos anónimos adscritos alguna vez a fray Luis, contamos con las versiones de una serie de discípulos y seguidores del agustino, que lo tienen como modelo directo y que demuestran con sus aportaciones el enorme florecimiento de la poesía bíblica tras la publicación de De los Nombres de Cristo, verdadera piedra de toque para la definitiva aclimatación de los salterios poéticos en España. En el más estricto seno de la congregación de san Agustín se encuadra la obra de Malón de Chaide, el Libro de la conversión de la Magdalena (Barcelona, 1588) que parece escrito entre 1578 y 1583, fechas de su estancia en Huesca; por las referencias a Nombres en el epílogo de la obra, Malón profesó en 1597 en el convento agustino de Salamanca, donde tuvo por maestro a fray Luis, que influyó notoriamente en su estro poético y preferencias literarias. Todo el libro, acabado poco después de la aparición de Nombres, está informado por el ejemplo del maestro, especialmente las versiones de los Salmos, intercaladas, según declara él mismo en la Dedicatoria, "para solo desempalagar el gusto cansado de la prosa”. La intención de desmentir a aquellos que pudieran pensar "que es menos gravedad en materia santa mezclar versos y cosas de poesía" le lleva a recrear en los preliminares el topos del carácter poético del Libro de David. [... ] La novedad que infunde a sus juicios radica en la conceptualización de los Salmos bíblicos como piezas líricas perfectamente equiparables a nuestros sonetos, canciones o romances, con lo que Malón actualiza la tesis de san Jerónimo sobre la existencia de hexámetros en la Vulgata, incardinándola en un marco de referencias literarias autóctonas (Núñez Rivera 2010: 138-13977).

En fin, Javier San José Lera ha dedicado varios trabajos a las paráfrasis bíblicas de fray Luis, en los que defiende con buenos argumentos que, lejos de ser meros ejercicios académicos de traducción, estas versiones poéticas constituyen tanto paráfrasis exegéticas como verdadera creación poética. Explica que estas paráfrasis en verso son "artefactos complejos" que deben ser estudiadas atendiendo a muy diversos aspectos de codificación del texto, no solo los lingüísticos y estilísticos, sino también los exegéticos y hermenéuticos. La cita que sigue es larga, pero creo que no tiene desperdicio:

\footnotetext{
Con respecto a estas traducciones, concluye: "A pesar del gran apego a los rasgos luisianos, estas versiones resultan en general mucho más diluidas y difusas que sus ajustadas traducciones" (139). A continuación menciona los textos que versificó Malón (un soneto y varias canciones, pero ningún romance), y menciona "Seis salmos sacados del Salterio de David para mover a la alabanza y amor de Dios”, conservados en los folios 44r-68v del Ms. 4.154 de la Biblioteca Nacional de España (Madrid), los cuales, según José Simón Díaz, han de atribuirse a Malón de Echaide (140).
} 
Traducción, poética y exégesis, en fin, se dan la mano en las versiones poéticas del siglo XVI con el fin de extraer toda la potencialidad de sentidos de los originales. Por eso acercarse a las paráfrasis de fray Luis como mero ejercicio de traducción no es otra cosa sino una excesiva simplificación. No se trata de identificar fuentes -nunca en fray Luis tiene sentido ese ejercicio-, sino de mostrar el complejo entramado exegético que urde la traducción, las estrategias de elaboración del poema, desde los principios poéticos a que atiende hasta la afinidad espiritual con que se construye el sentido, acercando el texto al sentimiento del autor de la traducción-poema-interpretación. De esta forma hay un movimiento que hace pasar la poesía del original a la poesía de la lengua receptora y otro que lleva de los sentidos explicados tradicionalmente en el texto al sentido construido en el mundo de referencias del autor, y que permite percibir el proceso de la traducción en todo [sic] su compleja trama de relaciones intertextuales.

Este proceso creativo muestra, en fin, la necesidad de atender no sólo a los aspectos técnicos de la traducción (la estrofa, por ejemplo, o la adaptación del género horaciano, como hace Núñez Rivera, 1993), sino a los procesos de construcción de sentido, por cuanto una paráfrasis es un modo de interpretación, y una paráfrasis en verso no es otra cosa que una interpretación que busca adecuarse a la naturaleza rítmica y poética del original. Traducir es interpretar, o como explica con lucidez Juan David García Bacca, es transfigurar, buscando la propia fuerza del texto para verter eso y no la mera literalidad, inventando un lenguaje nuevo (San José Lera 2006: 42-43; ver también San José Lera 2003 y 2010).

\section{El texto latino del salmo y su interpretación}

Este es el texto latino del salmo que versiona Malón:

$$
\text { PSALMUS } 83 \text { (84) }
$$

Desiderium templi Domini

1 In finem, pro torcularibus filiis Core. Psalmus ${ }^{8}$.

2 Quam dilecta tabernacula tua, Domine virtutum!

3 Concupiscit et deficit anima mea in atria Domini; Cor meum et caro mea exsultaverunt in Deum vivum.

4 Etenim passer invenit sibi domum, Et turtur nidum sibi, ubi ponat pullos suos.

\footnotetext{
8 Malón, que copia al margen el texto latino del salmo, omite este versículo introductorio.
} 
Altaria tua, Domine virtutum,

Rex meus, et Deus meus.

5 Beati qui habitant in domo tua, Domine;

In saecula saeculorum laudabunt te.

6 Beatus vir cuius est auxilium abs te,

Ascensiones in corde suo disposuit,

7 In valle lacrymarum, in loco quem posuit.

8 Etenim benedictionem dabit legislator;

Ibunt de virtute in virtutem,

Videbitur Deus deorum in Sion.

9 Domine, Deus virtutum, exaudi orationem meam;

Auribus percipe, Deus Iacob.

10 Protector noster, aspice, Deus,

Et respice in faciem christi tui.

11 Quia melior est dies una in atriis tuis super millia;

Elegi abiectus esse in domo Dei mei,

Magis quam habitare in tabernaculis peccatorum.

12 Quia misericordiam et veritatem diligit Deus,

Gratiam et gloriam dabit Dominus,

13 Non privabit bonis eos qui ambulant in innocentia.

Domine virtutum, beatus homo qui sperat in $\mathrm{te}^{9}$.

Los comentaristas explican que es este uno de los salmos de peregrinación, probablemente la ligada a la fiesta de las cabañas o los tabernáculos, dada la mención en el texto a las lluvias tempranas, las del otoño ${ }^{10}$. En la Biblia comentada por los Profesores de Salamanca, leemos la siguiente explicación del salmo, bajo el epígrafe "Anhelo de la presencia de Dios en el templo":

El yahvista fervoroso tenía toda su ilusión en vivir a la sombra del templo, participando de la familiaridad con su Dios en la asistencia a las funciones litúrgicas.

9 Biblia Sacra iuxta Vulgatam Clementinam nova editio logicis partitionibus aliisque subsidiis ornata a $R$. P. Alberto Colunga, O. P. et Dr. Laurentio Turrado, professoribus Sacrae Scripturae in P. Universitate Eccl. Salmanticensi, iterata editio, Matriti, Biblioteca de Autores Cristianos, 1953, 702a. Para un análisis más detallado del salmo (bibliografía, análisis filológico, exégesis, trasposición cristiana ... ), remito especialmente a Alonso Schökel y Carniti, 1992, 1095-1105; ver también Cayuela, 1947; Casciaro (dir.), 2001, 423-426; Drijvers, 1964, 172-173 y 259; González, 1966, 386-390; Guichou, 1966, 409-413; Kraus, 1995, vol. II, 251-260. Son igualmente interesantes los trabajos de Gunkel, 1983; Kraus, 1993; y Trebollé Barrera, 2001.

10 Alonso Schökel y Carniti 1993: 1099-1100 hablan de una triple peregrinación, la física, la espiritual y la ética, anunciada al final en el v. 12. 
Este salmo es similar a los salmos 42 y 43 . En éstos se refleja la nostalgia del levita que no puede asistir a la vida de culto del templo; en este salmo 84 se dan gracias a Dios y se entona un himno de alabanza por haberle otorgado el inmenso beneficio de poder tener acceso al santuario. Es la voz agradecida del peregrino que puede acercarse a la morada de Yahvé y vivir en intimidad espiritual con su Dios.

El salmo es lírico y no didáctico, y canta a Yahvé como Dios viviente, Señor de las jerarquías angélicas. Soberano de los ejércitos astrales, Israel es el pueblo escogido por este Dios omnipotente, y tiene su morada en el templo de Sión. El peregrino que llega a él se siente feliz, pues más vale un día en la casa del Señor que mil fuera de su recinto sagrado. Con toda ingenuidad muestra envidia de los sacerdotes y levitas, que pueden vivir permanentemente en los atrios del Señor. Consciente de su vinculación a la nación privilegiada, el salmista ruega por el ungido de Yahvé, el rey, que es el eslabón que conduce al Ungido por excelencia: el Mesías. Así, la oración del salmista es colectiva, pues se asocia a los intereses generales de la nación.

Por las alusiones al templo y al rey hemos de suponer que el salmo es anterior al exilio. Los reyes Ezequías y Josías, profundamente piadosos, habían fomentado las peregrinaciones al templo con motivo de la Pascua. Quizá el salmista refleje aquí una de estas circunstancias históricas de los tiempos gloriosos de la monarquía israelita (Profesores de Salamanca 1967: 512-513).

Y dividen el salmo en tres apartados: 1) la dicha del que habita en los atrios del Señor (versículos 1-5); 2) el peregrino de Yahvé (versículos 6-8); y 3) una súplica final (versículos 9-13). Por su parte, Alonso Schökel y Carniti han destacado su intensidad expresiva:

Si nos fijamos en el contenido, el salmo canta el templo de Sión como los Sal 46, 48, 63 y 87 (y 27,4-6). Podemos concretar: canta a Sión en un canto de peregrinación, como el Sal 122.

Pero no basta catalogar, no sea que se nos escape la intensidad lírica del poema, por la cual se emparenta con 42-43. Escuchemos la exclamación inicial repentina, la expresión de estado de ánimo en v. 3, la proyección sentimental en el ave (v. 4), los títulos personalizados de Dios en 4c, la elección gozosa de 11. Son efusiones que no se dejan encasillar (Alonso Schökel y Carniti 1993: 1098).

En el Comentario de la Sagrada Biblia preparado por la Facultad de Teología de la Universidad de Navarra, se presenta bajo el epígrafe "Manifestación al Señor del ardiente deseo de morar en su Templo":

Ya el grupo anterior de salmos de los hijos de Coré (Sal 42-49) comenzaba con el recuerdo anhelante de la peregrinación al Templo (cfr Sal 42,5). Algo 
parecido sucede ahora en Sal 84, con la diferencia de que aquí el salmista parece haber conseguido su deseo (Sal 84,11). La secuencia entre este salmo y el anterior parece estar señalada en que en aquél se confesaba a Dios como el que “sólo" Él era el Altísimo (cfr Sal 83,19), y en éste como "el Dios de los dioses" que habita en Sión (Sal 84,8).

A la confesión inicial del deseo de morar en el Templo para ser dichoso (vv. 2-5), sigue la proclamación de la dicha de los que peregrinan a Jerusalén (vv. 6-89), y la súplica por el rey acompañada del reconocimiento de los bienes que allí el Señor le otorga (vv. 9-12). Concluye proclamando dichoso a quien confía en Dios (v. 13).

Los deseos de morar en el Templo y la dicha de estar junto a Dios, tal como aparece en éste y en otros salmos (cfr Sal 120-134), los actualiza el cristiano en su deseo de vivir con Cristo (cfr Flp 1,21). Cristo es, en efecto, el Nuevo Templo de Dios (cfr Jn 2,21). De ahí que la meditación de este salmo sea un medio para fomentar las ansias de unirse íntimamente a Cristo en la celebración eucarística, y especialmente al recibirle en la Sagrada Comunión. Por eso, este salmo, junto con los dos siguientes (Sal 85 y 86) y con Sal 116 y 130, es uno de los que la Iglesia ha aconsejado rezar a los sacerdotes antes de celebrar la Santa Misa (Facultad de Teología de la Universidad de Navarra 2010: 529b-530a; ver también los comentarios de Guichou 1966: 409 y González 1966: 388).

\section{El texto de Malón de Echaide: la técnica de la amplificatio y el ornato retórico}

El poema de Malón, paráfrasis del Salmo 84 (Vulgata 83), "Quam dilecta tabernacula tua, Domine virtutum", se localiza en la "Parte primera del tratado de la Madalena”, $\$$ 1, al comienzo de la obra. Va explicando el agustino navarro que Dios es el fin de todas las cosas y que las criaturas intelectuales del cielo, los ángeles, no pueden dejar de amarse. En ese contexto, y como cierre del $₫ 1$, introduce su paráfrasis, cuyo texto ofrezco a continuación con una amplia anotación ${ }^{11}$ :

11 Cito el texto por la edición de La conversión de la Madalena (2014) de Ignacio Arellano, Jordi Aladro y Carlos Mata Induráin, 133-137, pero introduzco ligeros retoques. Añado además la numeración de versos para facilitar las referencias. El poema está recogido también en la antología Poetas navarros del Siglo de Oro, 48-51. 


\section{PSALMUS 83}

Quam dilecta tabernacula tua, etc. ${ }^{12}$

¡Qué amables tus moradas ${ }^{13}$,

Señor de los ejércitos del cielo ${ }^{14}$,

del alma deseadas,

que desmaya en pensallas ${ }^{15}$ desde el suelo!

$Y$ tal dulzura siente

cuando del Señor piensa en los umbrales ${ }^{16}$,

que al alma, de impaciente,

la dejan los espíritus vitales ${ }^{17}$.

Alégranse en Dios vivo ${ }^{18}$

mi corazón, mi carne, que, movidos

de aquel ardor nativo ${ }^{19}$

de estar contigo, dan por Ti gemidos.

12 El texto latino del salmo aparece en Malón en forma de acotaciones marginales.

13 ¡Qué amables tus moradas...: "El predicado 'qué amables' hay que escucharlo con su etimología de amor funcionando. [...] Resumiendo diríamos: el orante está enamorado del templo” (Alonso Schökel y Carniti 1993: 1101); "El poeta comienza con exclamaciones líricas, que expresan su afección y su nostalgia por la morada de Yahveh” (González 1966: 388); “Los 'atrios' del Señor son el templo y sus dependencias, en cuanto símbolo de la divina cercanía (Sal 65,5; 92,14; 96,9; 100,4)” (González 1966: 386, nota a v. 3).

14 Señor de los ejércitos del cielo: Malón traduce así Domine virtutum; es expresión que se reitera luego más veces, con distintas formas, en los vv. 26 ("rey de las virtudes"), 36 ("Señor de los ejércitos del cielo”), 65 (“¡Señor de las virtudes!”) y 109 (“Señor de las virtudes”). Pero virtutum remite al quinto coro de los espíritus celestiales en la jerarquía celeste, es decir, al ejército de los ángeles (ver San José Lera 2010: 433). En este primer cuarteto lira se plantea ya la antítesis cielo / suelo, que se reiterará más adelante en los vv. 53-56 (también queda sugerida, aunque no de forma tan explícita, en el v. 34, al contraponer serafines / suelo).

15 pensallas: pensarlas.

16 cuando del Señor piensa en los umbrales: la frase hace sentido (pensar del Señor, 'pensar acerca del Señor', en relación con el pensallas del v. 4); pero quizá se trate de una errata por "cuando del Señor pisa los umbrales". Mantengo, en cualquier caso, la lectura de la princeps, sin enmendar.

17 Los vv. 9-12 son expresión amplificada del deseo que siente el yo lírico de estar cuanto antes en presencia del Señor.

18 Dios vivo: expresión del concepto de Dios vivo, "el que viviendo siempre da la vida: ésta no es la meramente biológica, sino la vida plena, con abundancia de toda la gama de los bienes” (González 1966: 389); “Dios vivo, que es la vida misma y su fuente (Sal 42,3.9)” (González 1966: 386, nota a v. 3). Ver luego los vv. 97-108.

19 ardor nativo: ardor natural. 
Allí halla casilla ${ }^{20}$

a do ${ }^{21}$ descansa el simple pajarillo;

allí la tortolilla,

ejemplo de un amor casto y sencillo ${ }^{22}$,

hace su nido amado

a do ${ }^{23}$ guarda seguros sus polluelos,

$\mathrm{y} \mathrm{cabe}^{24}$ tu sagrado

$\operatorname{altar}^{25}$ descansa libre de recelos.

Allí la golondrina

parlera $^{26}$ con el pico artificiosa ${ }^{27}$,

junto a la ara divina ${ }^{28}$,

edifica su casa presurosa ${ }^{29}$.

A mí solo se cierra,

$¡$ ¡oh, rey de las virtudes ${ }^{30}$ !, este paso,

y acá, en ajena tierra,

lloro en destierro el infelice caso ${ }^{31}$.

¡Oh, bienaventurados

los que viven, Señor, allá en tu casa

20 Allí halla casilla: nótese en este verso -y en todo este cuarteto lira- la aliteración, así como el empleo de diminutivos afectivos (casilla, pajarillo, tortolilla). El símil de los pájaros que hacen su nido en las murallas del templo de Jerusalén es de gran intensidad poética, como comentan los intérpretes del salmo: "El detalle delicado de los pájaros que anidan en los muros del templo, le sirve para expresar su propio apego al mismo" (González 1966: 388); "La imagen del ave suena casi a proyección sentimental del poeta, como la cierva de Sal 42,2” (Alonso Schökel y Carniti 1993: 1101).

21 do: donde.

22 la tortolilla, / ejemplo de un amor casto y sencillo: en la tradición animalística y en la emblemática, la paloma es, en efecto, símbolo bien conocido de castidad y fidelidad conyugal. Covarrubias, en su Tesoro, escribe que «es símbolo de los casados».

23 a do: a donde, donde.

24 cabe: al lado.

25 sagrado / altar: nótese el encabalgamiento, figura retórica repetida varias veces en el poema (ver los vv. 21-22, 42-43, 51-52, 53-54, 69-70 y 103-104).

26 parlera: locuaz, parlanchina.

27 artificiosa: es predicativo referido a edifica, verbo que aparece dos versos después.

28 la ara divina: hoy diríamos más bien el ara divina, pero esa concordancia es usual en la lengua clásica.

29 edifica su casa presurosa: entiendo presurosa como predicativo también de edifica, y no como adjetivo que califique a casa.

30 rey de las virtudes: ver la nota al v. 2 .

31 infelice caso: nótese el empleo del epíteto, que se construye aquí con -e paragógica. Luego, en el v. 37, felice. 
$y$ en tus techos dorados ${ }^{32}$,

a do jamás la gloria y bien se pasa!

Que con un dulce canto,

cual de los serafines ${ }^{33}$, desde el suelo

te cantan: “¡Santo, Santo ${ }^{34}$,

Señor de los ejércitos del cielo!”.

¡Oh, felice y dichoso

el varón que te tiene a Ti por muro,

que el pecho generoso ${ }^{35}$

lo tiene en el peligro más seguro,

y en el corazón hace

caminos por do vienen las divinas

fuerzas, do el alma yace,

de Ti bajadas por secretas minas!

Todos los de este talle

andan como entre muchas limpias fuentes

de un deleitoso valle ${ }^{36}$,

apagando la sed en sus corrientes.

¡Oh, bienaventurado

el que en su corazón la escala ${ }^{37}$ arrima,

por do del estrellado

cielo se alcanza la superna ${ }^{38}$ cima!,

32 techos dorados: para esta imagen del cielo como palacio de oro, ver Gómez Solís 2010: 196, quien apunta ya el claro eco de fray Luis de León, oda "iQué descansada vida ... !": "Que no le enturbia el pecho / de los soberbios grandes el estado, / ni del dorado techo / se admira, fabricado / del sabio Moro, en jaspes sustentado!” (vv. 6-10).

33 serafines: espíritus que forman el primer coro de los ángeles; son nueve las jerarquías angélicas, a saber, ángeles, arcángeles, tronos, dominaciones, virtudes, principados, potestades, querubines y serafines (ver Arellano 2011: 415).

34 Santo, Santo: el canto del Sanctus, denominado también «Canto angélico», es una aclamación de reconocimiento de la grandeza y santidad de Dios, que une a la Iglesia terrestre con la celeste.

35 generoso: en el sentido etimológico latino de 'noble' (cultismo).

36 un deleitoso valle: en sentido literal, alude al valle de Bacá (que se puede traducir bien como 'valle de los bálsamos', bien como 'valle de lágrimas') que atravesaban los peregrinos en su camino hacia Jerusalén; en sentido amplio, es sintagma habitual que remite al topos clásico del locus amoenus.

37 escala: escalera.

38 superna: alta, superior (cultismo). Se refiere, en sentido literal, a los peregrinos que han llegado a Sión. En efecto, los vv. 45-52 aluden a la peregrinación física, real, a Jerusalén: "Dichosos también los judíos de las provincias que reciben de Dios la fortaleza y el ánimo para subir en peregrinación hacia el monte de Sión. Dios protege su viaje; cuando llegan a los lugares áridos, como el valle de Bacá, en los alrededores de Jerusalén, hace brotar fuentes o caer la lluvia, símbolo de la solicitud que tiene por los peregrinos y que recuerda la solicitud que tuvo para con los repatriados de Babilonia" 
mientras en este suelo

de lágrimas, do vive en su destierro ${ }^{39}$,

suspira por el cielo

perdido por aquel primero yerro ${ }^{40}$;

que $^{41}$ el legislador Cristo ${ }^{42}$

le vestirá de bienes con que halague

a su pueblo, que visto ${ }^{43}$

le servirá, porque con gloria pague,

60

y contino ${ }^{44}$ más fuertes

crecerán en virtud, hasta aquel punto

que se truequen las suertes

y vean todo el bien de Dios por junto ${ }^{45}$.

¡Señor de las virtudes,

óyeme hora ${ }^{46} \mathrm{y}$ atiende a mi gemido;

y para que me ayudes,

Dios de Jacob ${ }^{47}$, inclina a mí tu oído!

¡Oh, defensor y amparo

nuestro $^{48}$, pues mi destierro, Dios, has visto,

(Guichou 1966: 410). "Pero lo mismo que el salmista no es forzosamente un levita que reside en el templo, tampoco un peregrino que viene desde lejos y que describe su camino. Éstos son todos recursos expresivos de la atracción que Dios ejerce en su morada. El lenguaje del salmo tiene mucha más pregnancia de cuanto podría implicar una situación concreta. [...] En todas las grandes fiestas hay peregrinaciones hacia el templo. El poeta parece aludir concretamente a la de los tabernáculos en otoño, cuando las primeras lluvias traen su bendición sobre el país" (González 1966: 389).

39 en este suelo / de lágrimas, do vive en su destierro: estas palabras remiten claramente a la Salve Regina, "exsules, filii Evae [... ] gementes et flentes in hac lachrymarum valle"; ver Galván 2004.

40 primero yerro: alusión al pecado original de Adán y Eva en el Paraíso. Nótese en este cuarteto lira el contraste suelo / de lágrimas (el mundo) / cielo, que ya aparecía en los vv. 1-4.

41 que: lo entiendo con valor causal, 'porque'.

42 legislador Cristo: ya Orígenes hablaba de Cristo como legislador de los cristianos. Escribe Arellano (2011: 337): "Cristo no ha venido a abolir las leyes anteriores de los profetas (Mateo, 5, 17-19), pero la justicia nueva es superior a la antigua (Mateo, 5, 20-48), ya que la perfecciona".

43 visto: lo entiendo como participio de vestir, 'vestido'.

44 contino: continuamente.

45 Comenta Guichou (1966: 410): "Yendo de altura en altura (o creciendo en fortaleza) gracias a la ayuda divina, los peregrinos tienen la gran alegría de haber alcanzado la última altura: Sión, en donde Dios se les manifiesta en el misterio del templo".

46 hora: ahora.

47 Dios de Jacob: otro título dirigido al Señor, que se suma al ya comentado de "Dios de los ejércitos del cielo".

48 defensor y amparo / nuestro: otro caso de encabalgamiento versal; traduce así Malón las imágenes de escudo y torre, emblemas de Dios protector. 
vuelve tu rayo claro

y asiéntale ${ }^{49}$ en el rostro de tu Cristo!

De tu David te acuerda ${ }^{50}$,

que le ungiste en rey ${ }^{51}$ y desterrado

se ve; Dios, no se pierda:

confírmale Tú el reino que le has dado,

que mejor es un día

de los que allá se gozan en tu casa,

que mil ${ }^{52}$ de la alegría

que da el mundo a los suyos, corta, escasa.

Más quiero con trabajo ${ }^{53}$

ser en tu santa casa barrendero ${ }^{54}$,

o si hay otro ${ }^{55}$ más bajo,

que aquel me será a mí más placentero,

49 asiéntale: caso de leísmo.

so te acuerda: acuérdate. "Una vez llegado ante Yavé, el salmista pide a Dios que escuche su oración, especialmente la que hace por el "mesías", el ungido de Dios, el rey de Israel o el gran sacerdote" (Guichou 1966: 410).

51 le ungiste en rey: este recuerdo del ungido va en paralelismo con los títulos divinos aplicados poco antes en el poema a Dios, Dios de los ejércitos y Dios de Jacob. "No se trata con ello exactamente de interceder por el monarca, sino al contrario, de ponerle a él por mediador. El 'ungido' de Yahveh es 'escudo' del pueblo; Dios le ha elegido como su representante, le ha adornado con promesas singulares, y está por eso de algún modo obligado con él. El bien del pueblo está comprometido y también garantizado en la suerte de su rey. Al pedir que Dios le recuerde y tenga en cuenta, se está pidiendo por esta garantía colectiva: a la vez que por el rey, por todo el pueblo. Ni es siquiera necesario que haya en el momento un rey histórico, pues es su figura la que tiene valor de símbolo eterno de bendición divina” (González 1966: 389-390) “Oración por el Ungido o alegando al Ungido. La presunción es que se refiera al rey, como se lee en los relatos de Saúl y David y en varios salmos. En una lectura o composición postexílica sería el sumo sacerdote [... . En una lectura tardía puede identificarse con el Mesías escatológico, según Dn 9,25” (Alonso Schökel y Carniti 1993: 1103).

52 un día ... mil: "La comparación uno / mil es convencional y sirve para encarecer enfáticamente (por ejemplo Dt 32,20; Jos 23,10; Is 30,17; Sal 90,4; Ecl 7,28)” (Alonso Schökel y Carniti 1993: 1103).

53 trabajo: en el sentido, habitual en la lengua clásica, de 'fatiga, penalidad, sufrimiento'.

54 ser en tu santa casa barrendero: "Estar a la puerta no alude al oficio de los levitas porteros (1Cró 9,19); debe entenderse como una contraposición en este sentido: mejor el mero acceso a la puerta de la casa del Señor, que la plena hospitalidad de los impíos” (González 1966: 387, nota a v. 11). "Aun en el caso de que Dios no lo admitiera en su íntima presencia en el interior del templo y le obligara a quedarse a la puerta como si fuera un mendigo extraño, el salmista recibiría de Dios, sólo por esto, más alegría que la que pudiera encontrar como huésped de honor en las casas de los pecadores, porque Yavé asegura a los verdaderos fieles su poderosa protección, su gracia misericordiosa, su resplandeciente gloria o fortaleza, su generosa bondad para favorecerles, en una palabra, su amor, el tesoro más precioso" (Guichou 1966: 410).

55 otro: entiéndase 'otro trabajo', en el sentido aquí de 'empleo', 'oficio'. 
ni en las soberbias casas de señores ${ }^{56}$,

de jaspe fabricadas ${ }^{57}$,

gozando sus privanzas y favores;

que la misericordia

es la que Dios más ama y encarece,

90

y la paz y concordia

con quien ${ }^{58}$ lo pequeñuelo ${ }^{59}$ en alto crece $^{60}$,

y la verdad, nacida

de aquella celestial y eterna fuente,

y de allá decendida ${ }^{61}$

para endrezar ${ }^{62}$ acá la humana gente;

$y$ asi $^{63}$, por la primera

dará gracia el Señor al limosnero;

también por la postrera ${ }^{64}$

lo colmará de gloria al verdadero,

$y$ al justo e inocente,

no privará del bien que se le debe;

56 en las moradas / ni en las soberbias casas de señores: así parafrasea Malón 'in tabernaculis peccatorum", enlazando con los tópicos del Beatus ille y la aurea mediocritas (ver la nota siguiente). "Tiendas malvadas: puede tratarse de moradas suntuosas, fruto de injusticia, como las supuestas en Am 6,4 o Miq 6,10: 'la casa del malvado con sus tesoros injustos', o el palacio de Jr 22, 14s. El sentido equivale a: prefiero un cargo, aunque sea a la entrada del templo, a las comodidades que procura la injusticia” (Alonso Schökel y Carniti 1993: 1103).

57 de jaspe fabricadas: el jaspe es material suntuario, que aparece por ejemplo en la "Canción de la vida solitaria" de fray Luis, en el pasaje ya mencionado antes a propósito de los dorados techos: "ni del dorado techo / se admira, fabricado / del sabio Moro, en jaspes sustentado" (vv. 8-10).

s8 con quien: con las cuales.

59 pequeñuelo: nótese de nuevo el empleo del diminutivo afectivo.

60 crece: acrecienta, hace crecer.

61 decendida: descendida. La verdad se identifica con Dios (ver Arellano 2011: 393-395, con mención de abundantes pasajes bíblicos).

62 endrezar: la princeps -y con ella la edición de Arellano, Aladro y Mata Induráin- lee enderezar, pero debe ser endrezar para lograr la correcta medida del endecasílabo. Enmiendo, por tanto.

63 y la paz ... y así: nótese en este pasaje el polisíndeton anafórico de la conjunción copulativa $y$.

${ }^{64}$ la primera ... la postrera: los antecedentes son la misericordia (v. 89) y la verdad (v. 93), respectivamente. 
antes $^{65}$, en la luciente

región ${ }^{66}$ de donde todo el bien nos llueve ${ }^{67}$,

de resplandor cercado,

105

entre las jerarquías de la gloria ${ }^{68}$

gozará descuidado

del fruto que tendrá de su vitoria ${ }^{69}$.

¡Señor de las virtudes ${ }^{70}$,

defensa de los hombres verdadera ${ }^{71}$,

que en llamándote acudes,

dichoso aquel que en tu bondad espera ${ }^{72}$ !

De acuerdo con la interpretación de los comentaristas, que ya he mencionado, se trata del canto de un peregrino en honor del templo de Jerusalén y, por extensión, de Dios; como señala Guichou, el salmo manifiesta el "Deseo de Jesús por la casa del Padre" y, en otro orden de cosas, la "Aspiración de los cristianos hacia el cielo y hacia Dios" (ver Guichou 1966: 410-413).

Los 13 versículos latinos de la Vulgata (12 en realidad, pues Malón no recoge el primero, introductorio) se convierten en 28 cuartetos lira $^{73}$ (estruc-

65 antes: por el contrario.

66 luciente región: se trata de un sintagma bastante repetido en la literatura de los Siglos de Oro, pero que en este caso remite especialmente a la Oda XIII de fray Luis de León, "De la vida del cielo": "Alma región luciente, / prado de bienandanza, que ni al hielo / ni con el rayo ardiente / fallece..." (vv. 1-4; ver la nota de Alcina a este pasaje en la página 142 de su edición). Tenemos, pues, aquí otro claro eco directo de la poesía luisiana en la de Malón. El justo está rodeado de la eterna luz celestial, de ahí que se le presente luego "de resplandor cercado, / entre las jerarquías de la gloria" (vv. 105-106).

67 todo el bien nos llueve: estos versos, que conectan con el concepto de Dios vivo expresado en el v. 9, manifiestan la seguridad del hablante lírico en la obtención de los bienes y las gracias del cielo. Explican Alonso Schökel y Carniti (1993: 1100): "los que caminan = proceden honradamente, reciben de Dios favor, honor y bienestar (12). El viaje físico no se queda en puro ritualismo ni en dulce experiencia íntima, sino que compromete la conducta posterior del peregrino. (De ahí la interpretación que hacen algunos del v. 12 como cita de una liturgia de entrada.)”.

68 jerarquías de la gloria: alude al "Orden entre los diversos coros de los ángeles" (DRAE), es decir, a las nueve jerarquías angélicas, que ya enumeré antes: ángeles, arcángeles, tronos, dominaciones, virtudes, principados, potestades, querubines y serafines (ver Arellano 2011: 415).

69 vitoria: forma con reducción del grupo consonántico culto -ct-, victoria.

70 Señor de las virtudes: se repite de nuevo esta expresión, que ya aparecía al comienzo (y también al medio) del poema, lo que le dota de cierta estructura circular.

71 defensa de los hombres verdadera: conecta con los vv. 37-40 y con la formulación de los vv. 69-70, "defensor y amparo / nuestro".

72 dichoso aquel que en tu bondad espera: "Dios colma de una verdadera y profunda felicidad espiritual a aquel que se confía y adhiere a él con una fe total y sin límites” (Guichou 1966: 410).

73 Núñez Rivera (2010) estudia el modelo poético de fray Luis en el entorno agustino, y se refiere sucesivamente a "La corriente octosilábica" (148-149), "La tendencia clasicista: primacía de las estrofas 
tura $7 \mathrm{a} 11 \mathrm{~B} 7 \mathrm{a} 11 \mathrm{~B})$, que suman un total de 112 versos, en general con un ritmo bastante logrado. Ya en otra ocasión dejé escrito, a propósito de otra paráfrasis bíblica suya, que "Malón de Echaide opera por amplificación: parafrasea ampliamente los versículos originales [...]. Para ello recurre a la técnica de la amplificatio, bien conocida en la literatura renacentista" (Mata Induráin 2005: $120^{74}$ ). En cuanto a la elección del cuarteto lira, me parece acertada la explicación que ofrece San José Lera para fray Luis, la cual perfectamente podría extrapolarse a Malón:

La elección del molde poético para verter en él el poema original implica ya una toma de posición respecto al texto que se traduce, que incorpora la valoración poética del original, que sólo se puede verter adecuadamente como poesía, y que convierte al poema resultante en portador de valores estilísticos, en cuanto es capaz de presentar más elegantemente, aunque de forma más oscura, los perfumes poéticos del original, que en prosa se pierden; y en portador de valores exegéticos, por cuanto recoge mejor el misterio de los sentidos que oculta el original, también verso (San José Lera 2006: $35^{75}$ ).

Y en otro trabajo posterior explica, igualmente a propósito de fray Luis:

Un segundo momento de la traducción es el de la apropiación literaria del original mediante la incorporación de los elementos propios de la tradición poética occidental, como la estrofa o la rima, con el fin de proponer la traducción del poema original también en verso. En el Davidis Psalmi de Arias Montano (p. 5) pudo leer fray Luis la opinión del editor Plantino, que para valorar la novedad de su producto señala que sólo se puede verter correctamente aquello que el autor primero escribió en verso, si se utiliza el mismo modo [...]. Allí mismo, encuentra la aplicación de unos modelos rítmicos que, mutatis mutandis (lo que va del sistema métrico latino al castellano), pudieron servir de modelo [...]: el cuarteto lira 11A7b11A7b; este movimiento del verso largo y corto en alternancia reproduce el del dichocolon tetrastrophon que usa Arias Montano en su versión de los salmos (San José Lera 2010: 425).

aliradas" (149-155) y "La irrupción de la silva" (156-161).

$74 \mathrm{Y}$ en nota al pie señalaba que la de la amplificatio fue una técnica muy estimada igualmente en el Barroco, ofreciendo esta cita Lope de Vega en el prólogo a sus Rimas (Madrid, Pedro Madrigal, 1602): "La amplificación es la más gallarda figura en la Retórica, y que más majestad causa a la oración suelta". Por su parte, Cuevas García (2001: 31) indicaba: "No es raro, por lo demás, que fray Luis recurra por causas estilísticas a amplificationes, reductiones u omissiones de diversa índole".

75 Recuerda que fray Luis, en el prólogo al Cantar de los Cantares, había explicado la diferencia entre trasladar y declarar un texto. Para la estrófica de los Salmos y su utilidad en la crítica y en la exégesis, ver Galdós 1946 y Beaucamp 1968, entre otros estudios. 
Ya hemos visto por el comentario del salmo la idea central que subyace a todo el texto: estar lejos de Jerusalén es estar lejos del templo, luego es estar lejos de Dios. No puedo, en esta ocasión, descender al comentario detallado de todo el poema de Malón, verso por verso, ni entrar en un análisis exegético profundo ${ }^{76}$, ni analizar tampoco a fondo los procesos de cambio operados con respecto al texto latino de la Vulgata ${ }^{77}$. Ofreceré, sí, un esquema de correspondencias entre los versículos latinos y los versos del texto maloniano, lo que nos permitirá apreciar -al menos cuantitativamentelas diversas amplificationes llevadas a cabo por Malón:

\begin{tabular}{l|l}
\hline \multicolumn{1}{c|}{ Vulgata } & \multicolumn{1}{c}{ Poema de Malón } \\
\hline $\begin{array}{l}\text { Versículo 1, "In finem, pro tor- } \\
\text { cularibus filiis Core. Psalmus" }\end{array}$ & $\begin{array}{l}\text { Malón no lo traduce. Pone en su lugar el epígrafe } \\
\text { PSALMUS 83, “Quam dilecta tabernacula tua, etc." }\end{array}$ \\
\hline Versículo 2 & Versos 1-2 \\
\hline Versículo 3 & Versos 3-12 \\
\hline Versículo 4 & Versos 13-28 \\
\hline Versículo 5 & Versos 29-36 \\
\hline Versículo 6 & Versos 37-44 \\
\hline Versículo 7 & Versos 45-60 \\
\hline Versículo 8 & Versos 61-64 \\
\hline Versículo 9 & Versos 65-68 \\
\hline Versículo 10 & Versos 69-76 \\
\hline Versículo 11 & Versos 77-88 \\
\hline Versículo 12 & Versos 89-108 \\
\hline Versículo 13 & Versos 109-112 \\
\hline
\end{tabular}

76 Baste por ahora con remitir al apartado "Trasposición cristiana" del comentario que dedican al salmo Alonso Schökel y Carniti 1993: 1104-1005, donde hablan de la trasposición primero en clave cristológica presente (Jesús es el nuevo, el verdadero templo), en clave eclesiológica presente (el templo es la Iglesia), en clave cristológica del Señor glorificado y en clave eclesiológica futura. También copian algunos párrafos del comentario de este salmo ofrecido por San Agustín.

77 A diferencia de fray Luis, no nos consta que Malón hiciera sus paráfrasis directamente a partir del texto hebreo. Tampoco entro ahora en la consideración de qué versión latina de la Biblia pudo utilizar. Para mi propósito actual, no hace demasiado al caso, y me limito a señalar lo que indican Arellano, Aladro y Mata Induráin (2014: 70): "Los textos de la Biblia los debe de citar Malón en ocasiones de memoria, porque en algunos detalles no coinciden con la Vulgata". 
En la dispositio del poema, podemos observar la división tripartita del contenido del salmo que ofrecían los comentaristas, a saber:

1) Versos 1-28 (versículos 1-4 de la Vulgata): ponderación de la felicidad de los que habitan permanentemente cerca de la casa del Señor (vv. 1-8) y anhelo del peregrino por alcanzar sus atrios (vv. 9-12): esas amables ... moradas del v. 1 son, en sentido literal, el templo de Jerusalén y sus dependencias; en sentido figurado, estos versos constituyen un elogio de la alegría que se obtiene estando en la casa del Padre. Se emplea un sencillo pero hermoso símil poético, el de los pájaros (simple pajarillo, tortolilla, golondrina / parlera) que, al hacer sus nidos en las murallas del templo, encuentran en él refugio y protección (vv. 13-24). Por contraste, el hablante lírico se encuentra en situación de destierro, "en ajena tierra" (vv. 25-28).

2) Versos 37-64 (versículos 5-8 de la Vulgata): elogio por parte del salmista-peregrino de la suerte de aquellos que viven permanentemente en la casa del Señor, en tono exclamativo (“iOh bienaventurados”, v. 29; "Oh, felice y dichoso", v. 37; “Oh, bienaventurado”, v. 49). Se indica que la casa del Padre es como un palacio de techos dorados, donde la gloria y el bien son eternos. Quienes habitan en el templo proclaman santo al Señor, al igual que hacen los serafines en el cielo (el templo de Jerusalén es, entonces, claro trasunto de la Jerusalén celeste). En fin, la mención del valle deleitoso de limpias fuentes en las que los peregrinos pueden apagar su sed (vv. 45-48) alude a la peregrinación física, con una nueva referencia al destierro que sufre el hombre en este suelo / de lágrimas (el mundo) por culpa del pecado original cometido por nuestros primeros padres en el Paraíso (vv. 53-56).

3) Versos 65-113 (versículos 9-13 de la Vulgata): súplica final al Señor, marcada por el tono exclamativo y el empleo de vocativos dirigidos a Dios. El salmista-peregrino ruega al Señor que se acuerde del Ungido (el rey de Israel o el sumo sacerdote, en el plano literal / el Mesías Cristo, en el plano alegórico). Se añaden nuevos elogios de los bienes que se derivan de morar en la cercanía del Señor: un día en la casa del Padre, aun ocupando los oficios más bajos, es mejor que mil en las "soberbias casas de señores / [...] / gozando sus privanzas y favores" (vv. 86-88, donde apuntan temas relacionados con el elogio de la vida retirada y la aurea mediocritas). Y se insiste en la idea de que el justo y el inocente, rodeados de las jerarquías angélicas y enmarcados por 
su resplandor, gozan de la "luciente / región" (vv. 103-104) de donde viene (llueve, v. 104) al hombre todo bien. Termina el poema (vv. 109112) con el elogio del varón que espera confiado en la bondad de Dios.

En general, cabe afirmar que todo el poema se construye por medio de procesos de amplificación (hay también, por supuesto, algunas omisiones, pero no son tan significativas). Un notable caso de amplificatio lo tenemos en la versión que da Malón del versículo 3, cuyo texto latino dice:

"Etenim passer invenit sibi domum, / et turtur nidum sibi, ubi ponat pullos suos. / Altaria tua, Domine virtutum, / Rex meus, et Deus meus", y que se transforma en el largo pasaje de los vv. 13-28. Significativo es también el caso del versículo 11, "Quia melior est dies una in atriis tuis super milia; / Elegi abiectus esse in domo Dei mei, / Magis quam habitare in tabernaculis peccatorum", que se convierte en el pasaje desarrollado a lo largo de los vv. 77-88.

En cuanto al ornato retórico ${ }^{78}$, tan solo puedo destacar, de forma esquemática, los principales aspectos:

- Uso de numerosos vocativos e imperativos dirigidos al Señor, lo cual no ha de extrañarnos si tenemos en cuenta que en buena parte el poema se estructura como una súplica. Los vocativos son: Señor de los ejércitos del cielo (v. 2), rey de las virtudes (v. 26), Señor (v. 30), Señor de los ejércitos del cielo (v. 30), Señor de las virtudes (v. 65), Dios de Jacob (v. 68), defensor y amparo / nuestro (vv. 69-70), Dios (vv. 70 y 75), Señor de las virtudes (v. 109) y defensor de los hombres verdadero (v. 110). Y los imperativos (concentrados en el comienzo de la parte tercera del salmo, la súplica propiamente dicha del peregrino): óyeme hora y atiende a mi gemido (v. 66), inclina a mí tu oído (v. 68), vuelve tu rayo claro / y asiéntale en el rostro (vv. 71-72), De tu David te acuerda (v. 73) y confírmale Tú el reino (v. 76).

78 En un trabajo anterior (Mata Induráin 2005: 125) señalaba con relación a la paráfrasis maloniana de otro salmo: "En resumen, podemos concluir diciendo que esta composición presenta un alto grado de elaboración retórica, lo que contribuye a lograr un estilo rico y expresivo. Todo este adorno del lenguaje, unido a las bellas imágenes y comparaciones, junto con la técnica de la amplificatio y, por supuesto, la alta calidad poética de los versos italianizantes, manejados con soltura por Malón, hacen de este poema una paráfrasis bíblica que actualiza la Sagrada Escritura a través del poder de la palabra poética, capaz de perdurar -en su serena belleza- al paso de los siglos, capaz de actualizarse, también, en cada nueva lectura”. Estas palabras podrían aplicarse igualmente al poema que ahora comento. 
- La intertextualidad con la poesía de fray Luis, al menos en tres pasajes que he mencionado en nota al pie: techos dorados (v. 31), las soberbias casas de señores, / de jaspe fabricadas (vv. 86-87) y luciente / región (vv. 103-104).

- El uso bastante frecuente de encabalgamientos, con los que -entiendose trata de expresar el desasosiego del hablante lírico, deseoso de alcanzar la morada de Dios: sagrado / altar (vv. 19-20), golondrina / parlera (vv. 21-22), divinas / fuerzas (vv. 42-43), estrellado / cielo (vv. 51-52), suelo / de lágrimas (vv. 53-54), amparo / nuestro (vv. 69-70) y luciente / región (vv. 103-104).

- El empleo de abundantes epítetos: simple pajarillo (v. 14), nido amado (v. 17), infelice caso (v. 28), dulce canto (v. 33), limpias fuentes (v. 46), deleitoso valle (v. 47), superna cima (v. 52), rayo claro (v. 71), soberbias casas (v. 86), etc.

- La introducción de parejas de sinónimos o quasi-sinónimos: mi corazón, mi carne (v. 10), la gloria y bien (v. 32), felice y dichoso (v. 37), corta, escasa (v. 80), sus privanzas y favores (v. 88), ama y encarece (v. 90), la paz y concordia (v. 91), celestial y eterna (v. 94), justo e inocente (v. 101).

- En fin, el empleo con valor estilístico de repeticiones y paralelismos; a la repetición de los vocativos "Señor de los ejércitos del cielo" o "Señor de las virtudes", ya mencionada, añádase la de "Oh, bienaventurados", "Oh, felice y dichoso", "Oh, bienaventurado" (vv. 29, 37 y 49); la anáfora de "Allí ... allí ... Allí" (vv. 13, 15, 21, frente al allá del v. 27 y en relación con el acá del v. 30). Anáfora y paralelismo, combinados con el polisíndeton de la copulativa $y$, lo tenemos en el pasaje de los vv. 91-102.

Terminaré con una nueva cita de San José Lera, quien explica que en sus paráfrasis poéticas fray Luis llevó a cabo lo mismo que hizo en prosa en su declaración del Cantar de los Cantares, en el Libro de Job y en parte en De los nombres de Cristo, a saber,

con libertad se extiende, es decir, amplifica, añade y quita a voluntad, no copiosamente porque el género no lo permite; pero sí eligiendo el sentido que le interesa destacar para construir su propia interpretación y haciendo al tiempo poesía, como en el original. Por eso juzgar esos poemas desde criterios de la literalidad es un error de desenfoque que ha arrastrado a quienes (pocos) se han acercado a ellas. 
El corpus de las paráfrasis poéticas muestra tres acciones distintas: 1. Traducir un texto previo; 2 . Crear verso en la lengua propia para que suene lo más cerca posible del original (que está también en verso); 3. Construir una interpretación, porque el texto que se traduce no es poesía sin más, sino poesía orientada al conocimiento de los misterios de la palabra divina. Si la traducción es un ejercicio retórico, la creación supone poner en juego no sólo estrategias retóricas, sino también poéticas, manteniendo el espíritu de la creación original con toda su fuerza y todo su misterio (San José Lera 2006: 39).

Pues bien, todo lo predicado para las paráfrasis bíblicas de fray Luis se puede aplicar, mutatis mutandis, a las de fray Pedro Malón de Echaide, quien también vierte e interpreta los salmos, el "Quam dilecta tabernacula tua, Domine virtutum” en esta ocasión, en el molde de los cuartetos lira, cuyos heptasílabos y endecasílabos suenan con armoniosa cadencia y musical dulzura.

\section{Bibliografía}

ALADRO FONT, Jorge (1998). Pedro Malón de Echaide y "La conversión de la Magdalena". Vida y obra de un predicador. Pamplona: Gobierno de Navarra.

ALCÁNTARA MEJÍA, José Ramón (2002). La escondida senda: poética y hermenéutica en la obra castellana de Fray Luis de León. Salamanca: Ediciones Universidad de Salamanca.

ALONSO SCHÖKEL, Luis, y Carniti, Cecilia (1993). Salmos, II (Salmos 73-150). Traducción, introducciones y comentario. Estella: Verbo Divino.

ALONSO SCHÖKEL, Luis, y Zurro, Eduardo (1983). La traducción bíblica: lingüística y estilística. Madrid: Cristiandad.

ÁLVAREZ, Luis (1978). El movimiento observante agustiniano en España y su culminación en tiempo de los Reyes Católicos. Roma: Analecta Augustiniana.

ARELLANO, Ignacio (2011). Repertorio de motivos de los autos sacramentales de Calderón. Pamplona: Servicio de Publicaciones de la Universidad de Navarra. Disponible en <http://dadun.unav.edu/handle/10171/20441>.

ARELLANO, Ignacio, Aladro, Jordi, y Mata Induráin, Carlos (2014). "Introducción” a fray Pedro Malón de Echaide, in La conversión de la Madalena. New York: IDEA, 11-64.

BEAUCAMP, Evode (1968). "Structure Strophique des Psaumes”, Recherches de Science Religieuse, 56, 199-224.

Biblia Sacra iuxta Vulgatam Clementinam nova editio logicis partitionibus aliisque subsidiis ornata a R. P. Alberto Colunga, O. P. et Dr. Laurentio Turrado, professoribus Sacrae Scripturae in P. Universitate Eccl. Salmanticensi, iterata editio. Matriti: Biblioteca de Autores Cristianos, 1953. 
CAYUELA, Arturo María (1947). El salmo de los consagrados a Dios (Salmo 83/84). Barcelona: Librería Religiosa.

CUEVAS GARCÍA, Cristóbal (1982). Fray Luis de León y la escuela salmantina. Madrid: Taurus.

CUEVAS GARCÍA, Cristóbal (2001). “Introducción” a fray Luis de León, in Poesías completas. Propias, imitaciones y traducciones. Madrid: Castalia, 7-53.

DRIJVERS, Pius (1964). Los Salmos. Introducción a su contenido espiritual y doctrinal. Versión española por Jesús González. 2. ${ }^{a}$ ed. Herder: Barcelona.

[Facultad de Teología de la Universidad de Navarra, dir. José María Casciaro] (2001). Sagrada Biblia. Antiguo Testamento. Libros poéticos y sapienciales. Traducción y notas. Pamplona: Eunsa.

Facultad de Teología de la Universidad de Navarra (2010). Sagrada Biblia. Comentario. Pamplona: Eunsa.

FERNÁNDEZ DE CASTRO Y ÁLVAREZ, Eduardo Felipe (1928). El Salterio de David en la cultura española (Estudios histórico, crítico y bibliográfico). Madrid: Helénica.

GALDÓS, Romualdo (1946). "La estrófica de los Salmos y su utilidad en la crítica y en la exégesis”, in Estudios bíblicos, 5, 215-230.

GALVÁN, Luis (2004). “Valle de lágrimas’ y lugares de la gloria: la Celestina y el Salmo 83/84”, Celestinesca, 28, 25-52.

GÓMEZ SOLÍS, Felipe (2010). “Algunas referencias bíblicas metálicas de los espirituales españoles de los Siglos de Oro”, Caurensia, V, 185-200.

GONZÁLEZ, Ángel (1966). El Libro de los Salmos. Introducción, versión y comentario. Barcelona: Herder.

GUICHOU, Pierre (1966). Los Salmos comentados por la Biblia. Salamanca: Ediciones Sígueme.

GUNKEL, Hermann (1983). Introducción a los Salmos. Valencia: EDICEP.

KAPLIS-HOHWALD, Laurie (2003). Translation of the Biblical Psalms in Golden Age Spain. Lewiston (New York): Edwin Mellen Press Ltd.

KRAUS, Hans-Joachim (1985). Teología de los Salmos. Salamanca: Ediciones Sígueme.

KRAUS, Hans-Joachim (1995). Los Salmos. II. Salmos 60-150. Trad. de Constantino Ruiz Garrido. Salamanca: Ediciones Sígueme.

LEÓN, fray Luis de (1997). Poesía. Ed. de Juan Francisco Alcina. 8.a ed. Madrid: Cátedra.

LEÓN, fray Luis de (2001). Poesías completas. Propias, imitaciones y traducciones. Ed. de Cristóbal Cuevas. Madrid: Castalia.

MALÓN DE ECHAIDE, fray Pedro (2014). La conversión de la Madalena. Ed. de Ignacio Arellano, Jordi Aladro y Carlos Mata Induráin. New York: IDEA.

MATA INDURÁIN, Carlos (2005). “'Como la cierva en medio del estío...’: una paráfrasis del salmo 42-43 de Pedro Malón de Echaide”, in Gonzalo Aranda y Juan Luis Caballero 
(dirs.). La Sagrada Escritura, palabra actual. Pamplona: Servicio de Publicaciones de la Universidad de Navarra, 115-129.

MENÉNDEZ PELAYO, Marcelino (1953). Biblioteca de traductores españoles, III, Malón-Noroña, in Obras Completas. Santander: Aldus / CSIC.

MONASTERIO, Ignacio (1929). Místicos agustinos españoles. 2. ${ }^{\mathrm{a}}$ ed. El Escorial (Madrid): Editorial Agustiniana. 2 vols.

NÚÑEZ RIVERA, Valentín (2010). "Salmos y oda en el Siglo de Oro", in Poesía y Biblia en el Siglo de Oro. Estudios sobre los "Salmos" y el "Cantar de los Cantares". Madrid / Frankfurt am Main, Iberoamericana / Vervuert, 117-161.

Poetas navarros del Siglo de Oro (2003). Ed. de Carlos Mata Induráin. Pamplona: Fundación Diario de Navarra.

Profesores de Salamanca (1967). Biblia comentada. Texto de la Nácar-Colunga, IV, Libros Sapienciales, por Maximiliano García Cordero, O. P., y Gabriel Pérez Rodríguez. 2. ${ }^{\mathrm{a}}$ ed. Madrid: Biblioteca de Autores Cristianos.

SAN JOSÉ LERA, Javier (2003). “Fray Luis de León, 'Salmo I’: Traducción, poesía y hermenéutica”, Bulletin Hispanique, 105:1, 51-97.

SAN JOSÉ LERA, Javier (2006). “Las paráfrasis bíblicas de Fray Luis de León: poética, retórica y hermenéutica”, Via Spiritus, 13, 19-44.

SAN JOSÉ LERA, Javier (2010). “Exégesis bíblica y poesía en la paráfrasis del salmo 102 de fray Luis de León”, in Ignacio Arellano y Ruth Fine (eds.). La Biblia en la literatura del Siglo de Oro. Madrid / Frankfurt am Main: Iberoamericana / Vervuert, 421-438.

TREBOLLÉ BARRERA, Julio (2001). Libro de los Salmos: religión, poder y saber. Madrid: Trotta. 


\title{
Da Hermenêutica da Controvérsia Luterano-Católica ao Diálogo Contemporâneo. O 5. ${ }^{\circ}$ Centenário das 95 Teses de Lutero
}

\section{From the Hermeneutics of the Luteran-Catholic Controversy to the Contemporanean Dialog. The 5th Centenary of the 95 Theses of Luther}

\author{
Manuel Augusto Rodrigues \\ Universidade de Coimbra - CHSC \\ marodrigues@ci.uc.pt
}

Texto recebido em/Text submitted on: 15.09 .2015

Texto aprovado em/Text approved on: 24.10 .2015

Resumo: A Federação Luterana Mundial e a Igreja Católica decidiram há algumas décadas rever a situação criada no séc. XVI com a ruptura da unidade da Igreja. Para este novo clima ecuménico muito contribuíram o trabalho de vários teólogos ao longo de largos anos e algumas decisões do Concílio Vaticano II (1962-1965). Entretanto foi criada uma comissão mista luterano-católica encarregada de proceder a uma reavaliação das posições tomadas pela Igreja de Roma e pelos reformadores desde o início da cisão consumada em 1517. Dos documentos emanados dos encontros havidos entre ambas as partes salientamos os dois últimos: a "Declaração conjunta sobre a Justificação" (1999) e "Do Conflito à Comunhão" (2013). A evocação em 2017 do $5 .^{\circ}$ centenário das famosas 95 teses de Lutero justifica plenamente que se estude e analise a uma nova luz o que aconteceu no séc. XVI e depois ao longo da história. Teremos também presente o caso português com alguns exemplos da controvérsia instaurada.

Palavras-Chave: Controvérsia luterano-católica; 5. ${ }^{\circ}$ Centenário das 95 teses de Lutero; Reforma protestante

Abstract: The Lutheran World Federation and the Catholic Church of Rome decided since some years ago to review the situation created in the 16.th century with the rupture of the christian unity. For this new ecumenical clima of dialog was very important the work of various theologians and the Vatican Council II. A mixt Lutheran-catholic Comission produced some important documents such as "Joint Declaration on the Doctrine of Justification" (1999) and "From Conflict to Communion. Lutheran-Catholic Common Commemoration of the Reformation in 2017” (2013). The celebration of the 500 years of the 95 Luther's theses on the Power and Efficacy of Indulgences (Disputatio pro declaratione virtutis indulgentiarum) give a good opportunity for new investigations and studies. This work can benefit also the countries of the South Europe like Portugal where the fidelity to Rome became stronger with the decisions the Trient Council. 
Keywords: Lutheran-catholic controversy; 500 Years of the Luther's 95 Theses; Protestant Reformation

\section{Introdução}

A Reforma, seguida da Contra-Reforma e da Reforma Católica, deu origem a uma mudança de paradigma com reflexos em várias áreas e ao aparecimento de uma vasta literatura teológica e bíblica. No centro de tão profunda alteração que perdurou durante cinco séculos estão Lutero (Martin Luther) e o Concílio de Trento. O pai do movimento protestante, nascido em Eisleben a 10 de Novembro de 1483 e falecido na mesma cidade a 18 de Fevereiro de 1546, depois de um período de vida monástica como monge agostinho e professor de teologia veio a tornar-se a figura central da Reforma Protestante. A de Roma pretendeu com o Concílio de Trento (1545-1563) responder à ruptura criada em 1517 . Wittenberg foi o início de uma nova fase da história do cristianismo que dividiu o Velho Continente em duas metades, a que devemos juntar o caso do anglicanismo, à semelhança do que sucedera em 1054 com o Cisma do Oriente que separou Roma de Constantinopla. Da controvérsia medieval entre cristãos, judeus e muçulmanos, que culminaria com a sua expulsão de Portugal, passou-se à polémica com os Reformadores e com todos aqueles que se opunham à fé católica, através de vários instrumentos como a inquisição e os índices de livros proibidos, o Catecismo Tridentino e outros textos sancionados pela Igreja, sem esquecer o apoio de forças não eclesiásticas como o poder político de alguns estados. Também as outras religiões eram marginalizadas considerando-se o catolicismo, confinado à Europa e territórios recém-descobertos, como a única crença verdadeira. Servindo-se das missões, a Igreja católica e as outras saídas da Reforma trabalhavam para cristianizar, tarefa que ao tempo estava longe do conceito de inculturação.

Cingindo-nos ao tema proposto, começamos por falar da relevância especial que teve a série de encontros que a comissão mista luterano-católica para a unidade manteve desde há algumas décadas. Os temas tratados nos diversos documentos aprovados nas cincos fases de trabalho são esclarecedores: I. (1967-1972) "O Evangelho e a Igreja” (Malta-Relatório - 1972); II. (1973-1984): "A Ceia do Senhor" (1978), "Caminhos para a Comunhão" (1980), “Todos sob o mesmo Cristo" (1980), “O ministério espiritual na Igreja” (1981), "Martinho Lutero - Testemunha de Jesus Cristo” (1983), 
"Unidade diante de nós” (1984); III. (1986-1993): "Igreja e Justificação", (1993); IV. (1995-2006): "A Apostolicidade da Igreja” (2006), "Declaração conjunta sobre a Justificação", assinada pelos representantes da Igreja Católica e da Federação Luterana Mundial, 31 de Outubro de 1999; V: "Do Conflito para a Comunhão" (2013).

O Concílio Vaticano II (1962-1965), passado o longo período de 450 anos após a realização do Concílio de Trento, constituiu uma referência especial na história da Igreja de Roma. Pela primeira vez era reconhecido o princípio da liberdade religiosa com a aprovação da Declaração "Dignitatis humanae". A este documento juntam-se o "Nostra Aetate" sobre a Igreja e as religiões não cristãs e o Decreto "Unitatis Redintegratio" sobre o ecumenismo. Sirva de exemplo do novo clima que o Vaticano II criou o Decreto "Nostra Aetate", n. o 4, acerca dos judeus: «Além disso, a Igreja, que reprova quaisquer perseguições contra quaisquer homens, lembrada do seu comum património com os judeus, e levada não por razões políticas mas pela religiosa caridade evangélica deplora todos os ódios, perseguições e manifestações de anti-semitismo, seja qual for o tempo em que isso sucedeu e seja quem for a pessoa que isso promoveu contra os judeus. De resto, como a Igreja sempre ensinou e ensina, Cristo sofreu, voluntariamente e com imenso amor, a sua paixão e morte, pelos pecados de todos os homens, para que todos alcancem a salvação. O dever da Igreja, ao pregar, é portanto, anunciar a cruz de Cristo como sinal do amor universal de Deus e como fonte de toda a graça».

Já em 15 de Julho de 1970, o card. Willebrands abordava na V Assembleia da Federação Luterana Mundial o tema "Lutero, nosso mestre comum", e a 1 de Outubro de 1983 o Papa São João Paulo II enviava àquele cardeal uma mensagem por ocasião do 500..$^{\circ}$ aniversário do nascimento de Lutero. Bento XVI, no discurso de 23 de Setembro de 2011 dirigido aos representantes do Conselho da Igreja Evangélica da Alemanha por ocasião da sua viagem apostólica a este país, a 23 de Setembro de 2011, na alocução pronunciada em Erfurt durante a visita ao Augustinerkloster, onde Lutero viveu como religioso durante seis anos, reconheceu que a pessoa e a teologia de Martinho Lutero apresentam aos católicos um desafio espiritual e teológico. Afirmou o Papa Ratzinger: «O que não lhe dava paz era a questão acerca de Deus, que foi a paixão profunda e a mola da sua vida e de toda a sua caminhada. Como posso ter um Deus misericordioso?”: esta pergunta penetrava-lhe o coração e estava por detrás de cada investigação teológica e de cada luta interior. Para Lutero a teologia não era uma questão académica, mas a luta interior consigo mesmo, e isto, depois, era uma luta a respeito de Deus e consigo próprio: “Como posso ter um Deus misericordioso?”. Que esta questão foi a força 
motriz de todo o seu caminho toca-me sempre profundamente o coração», disse o Bispo de Roma ${ }^{1}$.

Através da passagem da hermenêutica da controvérsia ao diálogo contemporâneo, no estudo da Teologia e da Sagrada Escritura e de toda uma vasta literatura iniciou-se um processo de reanálise, revisão e reinterpretação que sem dúvida alguma se revela difícil e de longa duração. $\mathrm{O} 5^{\circ}$ centenário das 95 teses de Lutero será certamente uma excelente ocasião para avançar na longa caminhada que o futuro reserva.

A primeira questão que gostaríamos de analisar é esta: mas quem foi Lutero (1483 - 1546)? A partir da fase inicial da ortodoxia há que ter em consideração as diversas interpretações surgidas: no pietismo e durante as Luzes com Arnold, Spener, Leibnitz, Lessing, Semler, Strauss; no classicismo, no idealismo e no romantismo, altura em que se investigou na comparação de Kant com Lutero; de recordar ainda as análises de Haman, Goethe, Novalis, Heine, Schlegel e Hegel. Leopold von Ranke na circunstância do centenário de Lutero em 1817 dedicou-se intensamente a um acurado estudo da sua personalidade, concluindo por afirmar em Deutsche Geschichte im Zeitalter der deutschen Reformation (1839-1870) que o luteranismo é um período histórico próprio e com características peculiares, situado entre o final da Idade Média e a Época Moderna. Já mais perto de nós, deve atender-se aos comentários de Jansens, Görres, Marx, Kierkegaard, Burckhardt, Nietzsche, Feuerbach, e à nova teologia: Ritschl ("Deus absconditus"), Troeltsch, Gogarten, Karl Barth, sem esquecer Thomas Mann, Dilthey, Heideger e outros. Todos eles destacaram aspectos deveras importantes acerca da personalidade do filho de Einsleben, mas que aqui não podemos desenvolver como se impunha.

\section{O Centenário das 95 Teses de Lutero}

Dos documentos já referidos, fruto do trabalho conjunto entre a parte luterana e a católica-romana salientamos os dois últimos: a "Declaração conjunta sobre a Justificação" (1999) e "Do conflito à Comunhão. Comemoração conjunta luterano-católica da Reforma em 2017” (2013). Vale a pena analisar este importante documento de 2013, espécie de historial do passado

\footnotetext{
«Wie kriege ich einen gnädigen Gott»: Diese Frage hat ihn ins Herz getroffen und stand hinter all seinem theologischen Suchen und Ringen. Theologie war für Luther keine akademische Angelegenheit, sondern das Ringen um sich selbst, und dies wiederum war ein Ringen um Gott und mit Gott. "Wie kriege ich einen gnädigen Gott?". Daß diese Frage die bewegende Kraft seines ganzen Weges war, trifft mich immer wieder ins Herz».
} 
e de roteiro das tarefas a concretizar. Começa com um prefácio e uma introdução, seguindo-se um texto dividido em cinco capítulos com 245 pontos, acompanhados de 91 notas explicativas. Não sendo possível proceder a uma análise pormenorizada limitamo-nos a tecer algumas considerações mais relevantes. Logo a iniciar deparamos com estas palavras deveras eloquentes: $\ll \mathrm{O}$ conflito de Martinho Lutero com Deus guiou e determinou toda a sua vida. Foi constantemente perseguido pela questão: «Como posso ter um Deus misericordioso?». E encontrou aquele Deus misericordioso no Evangelho de Jesus Cristo. «No Cristo crucificado encontram-se a verdadeira teologia e o conhecimento de Deus». Continua o texto: «Em 2017 o modo mais justo para os cristãos católicos e luteranos de volver o olhar para acontecimentos de 500 anos atrás será o de colocar no centro o Evangelho de Jesus Cristo. O Evangelho devia ser celebrado e anunciado aos nossos contemporâneos, para que o mundo possa acreditar que Deus se dê a si mesmo aos homens e nos convide a entrar em comunhão com ele e com a sua Igreja. É esta a fonte da nossa alegria para a nossa fé comum».

A introdução alude ao $450 .^{\circ}$ aniversário da Confissão de Augsburg em 1980 e ao $5^{\circ}$ centenário do nascimento de Lutero em 1983 aos quais a Igreja de Roma se associou. A comemoração da Reforma numa era ecuménica e global, o carácter das celebrações precedentes, a evocação da primeira evocação ecuménica há 50 anos (em 2017 recorda-se a efeméride do diálogo luterano-católico romano), o novo contexto de secularização e os novos desafios que se colocam em 2017 - eis o objecto do c. I. Não podia faltar uma análise das novas prospectivas sobre Martinho Lutero e sobre a Reforma (c. II): os contributos da investigação histórica sobre a Idade Média e a pesquisa histórica católica do séc. XX sobre Lutero, lendo-se no $\mathrm{n}^{\circ} 22$ : «De forma nova, Lutero vem representado como uma pessoa de intenso fervor religioso e homem rigoroso de oração. Estudos históricos minuciosos e pormenorizados demonstraram que a literatura católica acerca de Lutero durante os quatro séculos da era moderna estava amplamente influenciada pelos comentários de alguns autores como Johann Cochlaeus (1479-1552) que escreveu Adversus cucullatum minotaurum ${ }^{2}$. Diz Cochlaeus a abrir: «Tardius editur haec mea qualisqualis responsio, candide lector, non eam sane ob Diz causam, quod difficile aut arduum visum fuerit, tam futili et vaniloquae criminationi lutherianae respondere, sed quod tanta est ubique fere, per bonam

\footnotetext{
Johann Cochlaeus ou Johann Dobneck (Wendelstein, Nüremberg, 1479 - 1552), humanista e controversista alemão e conselheiro do duque Jorge da Saxónia, tornou-se um acérrimo adversário de Lutero, que era seu contemporâneo. Apresentou Lutero como um monge apóstata, um destruidor da cristandade, um corruptor da moral e um herege como vem explanado no seu livro referido no texto.
} 
superioris Germaniae partem, Lutheranorum improbitas - quae nobis pro ecclesia et fide catholica pugnantibus plus difficultatis et impedimenti obiicit et ingerit quam Lutherus ipse -, ut mihi primum difficile fuerit, criminationem illam videre, visam deinde ultra diem unum retinere non licuit». Também no "Ad lectorem" apresenta as motivações da sua obra numa linguagem dura e agressiva. Tivera inicialmente uma grande simpatia para com Lutero, mas por volta de 1520 a sua atitude alterou-se totalmente passando para um criticismo atroz e uma acérrima oposição.

Dobneck escreveu ainda outras obras antiluteranas, entre elas esta de carácter popular que alcançou enorme divulgação: Commentaria Ioannis Cochlaei, de Actis et Scriptis Martini Lutheri. Cochlaeus desempenhou um papel importante nas Dietas de Worms (1521), de Nüremberg (1522-23), Speyer (1526) e Augsburg (1530), tendo-se nesta última revelado como um dos melhores teólogos, pelo que foi escolhido para refutar a Confissão luterana de Augsburg. Granjeou igualmente enorme fama na conferência de Worms de $1540^{3}$.

Outro grande opositor de Lutero foi Johannes Eck (1486-1543) com o seu Enchiridion locorum communium. Contra a Reforma luterana escreveram também importantes livros, entre outros, o cardeal Caetano, Melchior Cano e Pedro Canísio.

O resultado da primeira aproximação com a figura de Lutero nos últimos tempos, considerado crítico mas compreensivo, foi o de libertar os estudos católicos da aproximação unilateral própria daquelas obras polémicas sobre Lutero. Lúcidas análises históricas conduzidas por outros teólogos católicos mostraram que o que levou à divisão da Igreja não foram as questões cruciais de que se ocupou a Reforma, como a doutrina da Justificação; foram sim as críticas movidas por Lutero à situação da Igreja decadente do seu tempo. O n.o 23 "Do Conflito à Comunhão" prossegue o mesmo pensamento: «Para a averiguação histórica católica sobre Lutero o passo sucessivo foi a individuação da presença de conteúdos análogos encerrados em estruturas e sistemas de pensamento teológico diversos, de modo especial através de um confronto sistemático entre os teólogos mais representativos das duas

3 Remigius Bäumer escreve acerca de Cochlaeus: «Sein grosses Ziel, die Wiederherstellung der Einheit der Kirche, konnte nicht erreicht werden. Sein Einfluss auf die Konzilsväter in Trient, nicht zuletzt auf Bellarmini und seine Kontroversen, machen seine Bedeutung deutlich. In seiner Treu zum alten Glauben, seiner Opferbereitschaft und seinem Einsatz für die Kirche ist Cochläus vorbildlich. Sein theologeschichtlicher Einfluss wird nicht zuletzt sichtbar in den zahlreichen Nachdrucken seiner Werke. Den direkten und indirekten Einfluss sei noch seine Bedeutung für die Pädagogik, für die Musik und die Geographie». 
confissões: Tomás de Aquino e Martinho Lutero. Este trabalho consentiu aos teólogos compreender a teologia de Lutero colocando-a no seu próprio contexto. Revestiu-se de grande alcance a investigação católica sobre o significado da doutrina da Justificação à luz da Confissão de Augsburg (1530) onde Melanchton teve papel de relevo ${ }^{4}$. De tal modo o empenho reformador de Lutero pôde ser inserido no mais amplo contexto da formulação das confissões luteranas, que o intento da Confissão de Augsburg foi visto como a expressão de um desejo fundamentalmente reformador, mas também preocupado em preservar a unidade da Igreja $\gg^{5}$. Este capítulo conclui com algumas observações sobre projec-

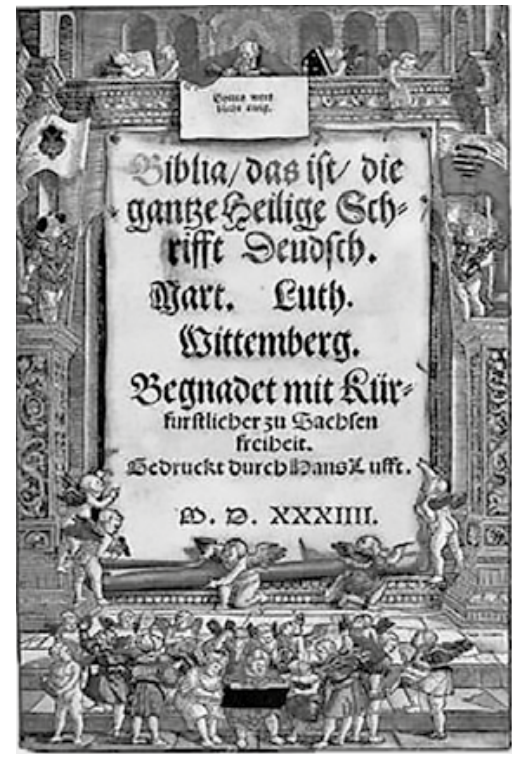

A Bíblia de Lutero, 1534 tos ecuménicos tendentes a preparar a via do consenso, a evolução luterana e a importância dos diálogos ecuménicos.

O tema "Uma síntese histórica da Reforma luterana e da reacção católica" vem desenvolvido no c. III: que coisa significa reforma? A causa desencadeada pela Reforma pode resumir-se nestes pontos: a controvérsia das indulgências, Lutero sob processo, os encontros falhados, a condenação de Lutero, os acontecimentos de Worms, os inícios do movimento da Reforma, a necessidade de uma supervisão eficiente, a elaboração de catecismos e de hinos e a criação de pastores para as paróquias. Para superar o conflito reli-

4 Philipp Melanchthon ou Philipp Schwartzerdt (Bretten 1497 - Wittenberg 1560) evidenciou-se como filólogo, filósofo, humanista, teólogo, professor e poeta neolatino. Foi juntamente com Lutero o grande impulsionador da Reforma alemã e europeia. Ficou conhecido como „Praeceptor Germaniae" e famoso pelos seus Loci theologici (Heubtartikel Christlicher Lere), Wittenberg: Kreutzer, Veit, 1553). escreveu obras de gramática, livros de instrução, lógica e retórica, teologia, comentários bíblicos e edições, autores latinos, autores gregos, ética, política e direito, antropologia e física, história e geografia, polémica e história da época, doutrina eclesiástica e prática, poesia. Uma das suas preocupações como em geral dos Reformadores foi a de criar escolas, colégios e universidades por toda a parte, tendo muitas das já existentes aderido à Reforma. Como resposta à Companhia de Jesus fundou diversos colégios e universidades em especial na zona meridional da Alemanha.

«A Confissão de Augsburg é um testemunho inequívoco da determinação que os Reformadores tinham de manter a unidade da Igreja visível. Ao apresentar-se explicitamente a diferença como de menor importância, a Confissão assume uma posição semelhante àquela que hoje chamaremos um consenso diferenciador (differentiating consensus)» $\left(\mathrm{n} .{ }^{\circ} 70\right)$. 
gioso não faltaram algumas tentativas teológicas que conduziram à passagem das guerras de religião para a paz de Augsburg. Outros temas apresentados no texto: o Concílio de Trento, a Escritura e a Tradição, a Justificação, os sacramentos, as reformas pastorais, as consequências da cisão consumada e o percurso até ao Concílio Vaticano II. A tradução da Bíblia para alemão foi um dos factos mais importantes da actividade do reformador de Wittenberg: o NT foi publicado em 1522 e a Bíblia com os livros apócrifos completa saiu dos prelos em 1534. Lutero pretendia levar a Palavra de Deus a todos, contrariamente à Igreja católica que manteve até há pouco tempo em latim a liturgia e a docência das ciências teológicas. A palavra de ordem era levar a Palavra de Deus a todos. A criação de escolas e a divulgação de catecismos foram uma preocupação constante dos arautos da Reforma que, entre outros actos, realizavam visitas pastorais com frequência às diversas comunidades.

As questões fundamentais da teologia de Martinho Lutero são apresentadas no c. IV à luz dos diálogos luterano-católicos: a estrutura deste capítulo, a herança medieval de Lutero, a teologia monástica e mística, a Justificação (interpretação de Lutero, a Palavra de Deus como promessa, só por meio de Cristo, a importância da lei, a participação da justiça de Cristo, a Lei e o Evangelho, as preocupações católicas acerca da Justificação, o diálogo luterano-católico sobre a Justificação, os temas "sola gratia”, a fé e as boas obras e "simul iustus et peccator"; e ainda a eucaristia, o ministério e as suas concepções comuns como o sacerdócio universal, a Palavra e os sacramentos, a Igreja universal, as diferenças na compreensão do ministério, a Escritura e a Tradição, a Igreja.

Acerca da Justificação remetemos para a "Declaração conjunta sobre a doutrina da Justificação".Este importante documento começa assim: «A doutrina da justificação teve importância central para a Reforma luterana do século XVI. Era considerada o "primeiro e principal artigo" e simultaneamente "orientador e juiz sobre todas as partes da doutrina cristã". A doutrina da Justificação foi particularmente sustentada e defendida na sua expressão reformadora e sua relevância especial face à teologia e à Igreja católica romana de então, as quais, por sua vez, sustentavam e defendiam uma doutrina da justificação com características diferentes. Aqui, segundo a prospectiva reformadora, residia o cerne de todas as confrontações. Elas resultaram em condenações doutrinais nos escritos confessionais luteranos e no Concílio de Trento da Igreja católica romana. Essas condenações vigoram até hoje e têm como efeito a divisão entre as Igrejas». E termina com estas palavras: $\ll \mathrm{O}$ significado e o alcance do consenso obtido: "A compreensão da doutrina da Justificação exposta nesta DC mostra que entre luteranos e católicos 
existe um consenso em verdades básicas da doutrina da Justificação. À luz desse consenso as diferenças remanescentes na terminologia, na articulação teológica e na ênfase da compreensão da Justificação descritas nos parágrafos 18 a 39 são aceitáveis. Por isso as formas distintas pelas quais luteranos e católicos articulam a fé na Justificação estão abertas entre si e não anulam o consenso nas verdades básicas» (no 40)6. "Chamados a uma comemoração comum" é o título do c. V, que inclui cinco imperativos ecuménicos. De notar que no n. 244 foi incluída uma parte do prefácio das obras latinas de Lutero em que se refere a Agostinho: $\ll \mathrm{O}$ caminho ecuménico permite a luteranos e católicos apreciar conjuntamente as intuições e a experiência espiritual de Martinho Lutero relativamente ao Evangelho da justiça de Deus, que é também misericórdia de Deus. No prefácio das suas obras latinas (1545) observou que «meditando dia e noite foi conduzido pela misericórdia de Deus» a compreender de uma maneira nova a Epístola aos Romanos 1,17, ("iustus ex fide vivit”): «Então senti-me literalmente renascido e introduzido através de portas abertas no próprio paraíso. Toda a Bíblia adquiriu para mim de improviso um novo rosto. Mais tarde assimilei o espírito e a letra de Agostinho, onde, contra toda a esperança, descobri que também ele interpretava a justiça de Deus de modo semelhante, como a justiça de que Deus nos reveste quando nos justifica $\gg$. Em latim: «Donec miserente Deo meditabundus dies et noctes connexionem verborum attenderem, nempe: Iustitia Dei revelatur in illo, sicut scriptum est: Iustus ex fide vivit, ibi iustitiam Dei coepi intelligere eam, qua iustus dono Dei vivit, nempe ex fide, et esse hanc sententiam, revelari per euangelium iustitiam Dei, scilicet passivam, qua nos Deus misericors iustificat per fidem, sicut scriptum est: Iustus ex fide vivit. Hic me prorsus renatum esse sensi, et apertis portis in ipsam paradisum intrasse. Ibi continuo alia mihi facies totius scripturae apparuit. Discurrebam deinde per scripturas, ut habebat memoria, et colligebam etiam in aliis vocabulis analogiam, ut opus Dei, id est, quod operatur in nobis Deus, virtus Dei, qua nos potentes facit, sapientia Dei, qua nos sapientes facit, fortitudo Dei, salus Dei, gloria Dei. Iam quanto odio vocabulum 'iustitia Dei' oderam ante, tanto amore dulcissimum mihi vocabulum extollebam, ita mihi iste locus Pauli fuit vere porta paradisi. Postea legebam Augustinum "De Spiritu et Litera" 1, ubi praeter spem offendi, quod et ipse iustitiam Dei similiter interpretatur: qua nos Deus induit, dum nos iustificat. Et quamquam imperfecte hoc adhuc sit

\footnotetext{
6 Vem citado o famoso texto da Conferência Episcopal alemã, "Lehrverurteilungen - Kirchentrennend? Die deutschen Bischöfe Stellungnahme der Deutschen Bischofskonferenz zur Studie „Lehrverurteilungen - Kirchentrennend? (21 de Junho de 1994, 163, 53113).
} 
dictum, ac de imputatione non clare omnia explicet, placuit tamen iustitiam Dei doceri, qua nos iustificemur».

Em conclusão, o documento "Do Conflito à Comunhão" traça uma história bem elaborada do que foi o percurso histórico das relações entre a Igreja e o Luteranismo, ao mesmo tempo que fornece uma análise pormenorizada dos pontos discutidos, interpretados de uma forma positiva e conciliadora.

Em 2017 será evocada a afixação por Lutero das suas famosas 95 teses na porta da igreja do castelo de Wittemberg a 31 de Outubro daquele ano, dia que passou a ser considerado o "Dia da Reforma". Pela primeira vez a comemoração insere-se num novo contexto global e secularizado. $\mathrm{O}$ primeiro centenário de Lutero celebrou-se em 1617 com grande aparato; em 1917 o povo alemão reconheceu-o como seu herói nacional. Mais junto a nós, registe-se a evocação do seu nascimento e morte, a que se associou a Igreja de Roma. A celebração de 2017 constitui mais um pretexto para intensificar o diálogo entre a Igreja de Roma e o protestantismo. $\mathrm{O}$ evento traz necessariamente à memória a época quinhentista, o período do humanismo que muito beneficiou a cultura de que ser serviu a Reforma, rica em muitos aspectos mas muito complexa em vários domínios, incluindo a Teologia e a Sagrada Escritura. Mas como se viu pela polémica com Erasmo, Lutero e os Reformadores procuravam ir mais além, ao encontro da mística e da Palavra de Deus na sua autenticidade, perante uma fase final da Idade Média que já não respondia aos anseios humanos. A Igreja católica carecia de uma profunda reforma. O Consilium de emendada Ecclesia (1536) ficou letra morta e quando o Concílio de Trento iniciava os seus trabalhos em 1545 já a Reforma tinha criado raízes fundas e os seus frutos estavam à vista de toda a gente. Múltiplas foram as implicações em diversas áreas que estão para além das estritamente religiosas. Algumas das efemérides celebradas nos últimos anos têm proporcionado conhecer melhor as reacções surgidas entre reformadores e católicos. Há que distinguir a teologia de Lutero da teologia luterana e sua evolução. A controvérsia de outrora deu lugar na actualidade ao diálogo ecuménico e inter-religioso. Os problemas que então foram mais debatidos na Pré-Reforma e depois na Pós-Reforma estavam mais de acordo com a tradição medieval do que com as novas aquisições teológicas, filosóficas, culturais e científicas. Valorizou-se a parte doutrinal e também a disciplinar. No meio dum ambiente político agitado a controvérsia instalara-se em especial nos países da Europa setentrional enquanto os do Sul se mantiveram fiéis a Roma. Nestes últimos tentava-se a todo o transe através de várias medidas como a inquisição e os índices de livros proibidos impedir a infiltração de 
qualquer tipo de luteranismo, como nos elucidam claramente H. Jedin, J. Lortz e muitos outros.

Como já ficou dito, o Concílio Vaticano II (1962-1965) ficou como ponto de referência na mudança de paradigma. Iniciou uma nova fase nas relações da Igreja católica com as outras confissões cristãs e com as religiões não cristãs, as diversas crenças, culturas e civilizações. Passados mais de 400 anos sobre o Concílio de Trento sancionava-se uma aspiração que já vinha, pelo menos do séc. XIX, no sentido de se rever o passado à luz do pensamento moderno e das aspirações que os sinais dos tempos vinham manifestavam. A promoção do ecumenismo e do diálogo inter-religioso muito ficou a dever a vários autores e instituições que desde o séc. XIX se dedicaram àqueles temas. Em ordem a levar por diante o diálogo com outros grupos cristãos foi renovado o Pontifício Conselho para Promoção da Unidade dos Cristãos junto do qual funciona a Comissão para as Relações com o Judaísmo e elaborados documentos importantes. Se no séc. XVI prevalecia a ideia de cristandade, que remontava à "Pax constantiniana" que Lorenzo Valla e outros vieram a denunciar, com a conivência dos poderes temporal e espiritual ou a supremacia do último sobre o primeiro, a pouco e pouco a situação alterou-se. Exemplo disso foi a extinção dos estados pontifícios que haviam perdurado de 752 a 1870. Para se ter uma ideia do clima reinante lembremos que o primeiro documento de toda a história da Igreja a definir a liberdade religiosa é a Declaração "Dignitatis Humanae"do Concílio Vaticano II. O texto vinha ao encontro das grandes alterações culturais e ideológicas surgidas a partir do séc. XVIII. Foi sendo posto em causa o axioma "extra Ecclesiam nulla salus", que remonta talvez a S. Cipriano e que figura no Il Catecismo do Concílio de Trento. $\mathrm{O}$ artigo sobre a catolicidade da Igreja sintetiza: «Quantos querem conseguir a salvação eterna devem aderir à Igreja, não diversamente daqueles que, para não morrerem no dilúvio, entraram na arca». Encontramos aquele princípio na condenação do indiferentismo condenado pelo "Sillabus" que o Papa Pio IX publicou juntamente com a encíclica "Quanta cura” a 8 de Dezembro de 1864. O Concílio Vaticano II na constituição dogmática "Lumen Gentium" (c. 4) e no decreto "Unitatis redintegratio" (c. 3) forneceu uma interpretação que abre a porta à extensão da revelação bíblica às outras religiões não cristãs (os cristãos anónimos), assunto abordado por alguns teólogos como Karl Rahner em vários estudos 7 . É pois à luz desta

Rahner, Karl (1961). "Das Christentum und die nichtchristlichen Religionen” (28.4.1961); Id. (1962). "Bekenntnis zu Jesus Christus" ("Profissão de fé em Jesus Cristo"), em Schultz, Hans Jürgen, (ed.) Juden Christen Deutsche, Stuttgart, 1991. Schriften zur Theologie 5, 1962, 136-158; Id. (1975). “Der eine Jesus Christus und die Universalität des Heils”, ibid. 12, 1975, 251-282; Id. (1975). 
mudança de paradigma que hoje temos de ler os escritos dos reformadores e dos autores católicos da Reforma católica e da Contra-Reforma.

\section{I. A controvérsia anti-luterana em Portugal}

No período áureo da cultura portuguesa surgiu um apreciável número de autores na área das ciências religiosas e filosóficas, alguns deles professores das Universidades de Coimbra e de Évora e de conventos e mosteiros do Reino. Salientamos entre os teólogos e biblistas: os bispos de Braga, Bartolomeu dos Mártires (1514-1590), de Coimbra, João Soares (1545-1572) e de Silves, Jerónimo Osório (1515-1580), os dominicanos Jerónimo de Azambuja (+1563), Francisco Foreiro (+ 1581) e Luís de Sotomaior (1526-1610), os jesuítas Manuel de Sá (+ 1590), Sebastião Barradas (1542-1615) e Cosme de Magalhães (1624), e o crúzio Pedro de Figueiró (+ 1592); na dogmática sobressaíram os dominicanos Gaspar dos Reis (1510-1584) e João de S. Tomás (1589-1644), Diogo Paiva de Andrade (1528-1575) e o inaciano Cristóvão Gil (1608); como escritores místicos lembramos Heitor Pinto (1584), Amador Arrais (1600), Tomé de Jesus (1582) e Agostinho da Cruz (1540-1619); como filósofos brilharam os autores do Curso dos Conimbricenses, Pedro da Fonseca (1599), Manuel de Góis (1593), Sebastião do Couto (1639) e, em particular, Francisco Suárez, enquanto na Universidade inaciana de Évora, criada em 1559, brilhava Luís de Molina. Podíamos alargar a lista com a menção de célebres oradores e canonistas.

Sem entrar em pormenores, refira-se que o Concílio de Trento no qual participaram alguns dos autores citados deixou marcas profundas na vida da Igreja e na sociedade que se mantiveram até aos nossos dias e que todos os autores referidos revelam a mentalidade de Trento. Como exemplos de polemistas anti-luteranos escolhemos Paiva de Andrade e Jerónimo Osório sobre os quais nos limitamos a tecer algumas breves considerações. Pensamos noutra ocasião tratar de outros autores como Bartolomeu dos Mártires e de Francisco Suárez.

\footnotetext{
"Jesus Christus in den nichtchristlichen Religionen", ibid. 12, 1975a, 370-383 (primeira publicação em 1974 na documentação de um simpósio sobre o conceito da revelação que teve lugar na Índia); Id. (1984). "Erfahrungen eines Theologen", in Herder Korrespondenz 38, 1984, pp. 224- 230; Id. (1978). "Über die Heilsbedeutung der nichtchristlichen Religionen”, ibid. 13, 1978, 341-350; Id. (1991). "Bekenntnis zu Jesus Christus" ("Profissão de fé em Jesus Cristo"), em Schultz, Hans Jürgen (ed.), op. cit.
} 
Diogo de Paiva de Andrade 8 , manteve uma renhida polémica com o reformador Martin Chemnitius ${ }^{9}$ contra o qual escreveu três obras de controvérsia: Defensio Tridentinae Fidei Catholicae, Orthodoxarum Explicationvm Libri Decem e De Societatis Iesv Origine ${ }^{10}$. Além destas obras editou ainda: Concio habita ad Patres in concilio Tridentino congregatos e uma Introdução em 18 páginas ao livro de D. Fr. Bartolomeu dos Mártires Stimulus pastorum.

No Orthodoxarvm Explicationum Libri Decem trata de questões então bastante debatidas: De origine Societatis Iesu, De Sacra Scriptura, De peccato, De libero arbitrio, De lege et Evangelio, De justificatione et fide, De Coena Domini, De poenitentia, confirmatione et extrema unctione, De veneratione sanctorum et imaginibus e De coelibatu. O título da Defensio revela bem o azedume contra Chemnitius: «Adversus haereticorm destestabiles calumnias et prasertim Martini Kemnicii germani». Ao longo de 979 páginas Andrade trata de alguns problemas debatidos então: De generalibus Conciliorum auctoritate, De Sacrae Scripturae Traditionumque auctoritate, De Libris Canonicis, De Vulgatae Latinae editionis auctoritate, sendo o quinto livro dividido em: De peccato originali, De originalis peccati reliquis, sive de Concuspicentia, quae post Baptismum in mente est reliqua e De Virginis Deiparae Conceptione. Nas duas obras, fundamentando-se na argumentação tradicional, constata-se a sua grande perspicácia e uma assinalável erudição.

Jerónimo Osório, conhecido por "Cícero lusitano", deixou uma vasta obra de índole humanística de que Francisco Leite de Faria nos dá um valioso elenco no excelente artigo intitulado "As muitas edições das obras de Dom Jerónimo Osório" ${ }^{11}$, registando as edições da obra De Iustitia. Os Opera omnia do Bispo de Silves foram editados em Roma em 1592 pelo seu sobrinho e homónimo em 4 ts.

D. Jerónimo editou também algumas paráfrases a certos livros sapienciais: In Psalmos, In Isaiam Libri V, In Job e In Sapientiam Salomonis; e os

8 O livro de A. Guimarães Pinto intitulado Diogo de Paiva de Andrade. Antologia inclui uma introdução (percurso biográfico, obras e notas sobre esta edição), alguns apêndices (carta ao cardeal Estanislau Hósio, uma carta a Benedito Arais Montano, a Dedicatória do Examen Concilii Tridentini de Martin Chemnitius) e uma antologia (oração perante os Padres de Trento, introdução ao Stimulus Pastorum de Bartolomeu dos Mártires, exposições ortodoxas de defesa da fé tridentina e sermões).

9 Chemnitius (Martin Chemnitz (1522 - 1586) evidenciou-se como notável teólogo e ficou conhecido como "Alter Martinus": «Si Martinus non fuisset, Martinus vix stetisset». Escreveu, entre outros, Examen concilii Tridentini (1573). Franckfurt a. M: Feierabend.

10 No prefácio escreve Osório, quando Andrade já tinha falecido: «Fuit igitur opus ut Payva more suo rursus arma sumeret: et hostem immanem insita virtute profligaret ...cum causam Ecclesiae suscepit, ut hominum perditorum amentiam refutaret, et hostilem impetum fortiter et animos reprimeret».

11 Faria, Francisco Leite de (1981). Revista da Biblioteca Nacional, 1. Lisboa: Biblioteca Nacional, 115135. 
comentários bíblicos: In Epistolam B. Pauli ad Romanos Libri IV, In Oseam, In Zachariam e In Parabolas Salomonis ${ }^{12}$. Seleccionámos para uma breve abordagem o tratado De Iustitia libri decem contra Lutero que A. Guimarães Pinto traduziu para português em 1999. Destacamos a inclusão da Assertio omnium articulorum M. Lutheri per Bullam Leonis X damnatorum, opúsculo de 68 páginas (Wittenberg 1520), do De libero arbitrio diatribe de Erasmo (1524), da Defensio sanae et orthodoxae doctrinae de servitute et liberatione humani arbitrii, adversus calumnias Pighii (Genebra 1545) e do De aeterna Dei praedestinatione (ibid. 1552), ambos de Calvino.

Com este nosso trabalho que é dedicado essencialmente ao tema indicado no título pretendemos também homenagear D. Jerónimo Osório cujo 5. ${ }^{\circ}$ centenário será comemorado brevemente num congresso a ter lugar em Coimbra e Lisboa. Sebastião Tavares de Pinho, entre outros, tem estudado em valiosos trabalhos a excepcional personalidade daquele grande humanista, tendo num deles incluído alguns dados que se prendem com a Universidade de Coimbra e com Paiva de Andrade.

O De Iustitia divide-se em dez livros, neles revelando o prelado algarvio a sua notável formação humanística que aproveita para defender a ortodoxia católica contra o luteranismo. No proémio o texto é marcado por algumas notas pessimistas e por um vivo realismo. Cita vários autores clássicos como, por exemplo, Hesíodo: «Optimus (inquit) ille est, qui per se tenet omnia mente. Quidque futurum sit tandem magis utile cernit. Commodus atque ille est, qui paret recta momenti. Qui vero non ipse sibi bene consulit unquam, nec paret rectis unquam monitoribus ultro, utilis ad nulla, esse potest hic munera vitae» (Trabalhos e dias, v. 293) e faz a comparação com Tântalo no suplício que sofreu nos infernos.

Entre as questões levantadas por Lutero deparamos no 1.2 com uma refutação do seu conceito de fé: «Prius tamen, quam ad hanc tantarum rerum explicationem propius accedamus, operae pretium erit, aliud fidei genus in medium afferre, mirum et novum atque priscis temporibus inauditum, cuius auctor est Lutherus» (fl. $\left.15 \mathrm{v}^{\circ}\right)$; «Quid igitur nos decipis, Luthere? Quid

12 Está em curso a edição dos Opera omnia em latim e português pela APENEL (Associação Portuguesa de Estudos Neolatinos), na série Portvgalliae Monumenta Neolatina, dir. de Sebastião Tavares de Pinho. Já foi editado no vol. IV dos Opera o t. I contendo Paráfrases a Job e à Sabedoria de Salomão com trad. por A. Guimarães Pinto. Imprensa da Univ. de Coimbra/Univ., Março 2009. Neste momento encontram-se nos prelos os ts. 15 e 16: Epistolografia do Bispo de Silves e Comentários aos Provérbios de Salomão, ambos com trad. de A. Guimarães Pinto e fixação do texto por Sebastião Tavares de Pinho. 
aciem mentis nostrae verborum novitate perstringis? Cur hominibus tuis, qui te tanto honore prosequuntur, illudis?».

Depois de tratar da fé de Abraão refere-se aos judeus, cegos perante a verdade, e a Paulo que ensinou lucidamente a Palavra de Cristo (1.3). Alude no 1. 4 aos homens célebres da antiguidade, Platão, Ovídio, Cícero, Ésquilo, Virgílio, Valla. Platão, Ovídio, Cícero, Ésquilo, Virgílio, Valla, etc., que nas suas obras manifestam revelam mesmo sem fé provam a verdade da ortodoxia. Foram pessoas virtuosas que viveram outrora e que não receberam nenhum conhecimento da divina lei. Como responder a esta questão? Começa assim: «Incidit autem quaedam minime, ut arbitror, aliena hoc loco dubitatio, quae diiudicanda est; ut commodius omnem hanc de fide quaestionem concludere neceat. Legimus enim multos olim homines extistisse, in omni genere laudis excelentes, eximiisqus maximaraum virtutum ornamentis excultos, qui nullam fortasse unquam disciplinam divinae legis acceperunt». Qual a posição a tomar relativamente a esses casos?: «Quid ergo statuemus? Eos fidei viribus excitatos fuisse ut non inania simulachra virtutis, sed solidam et expressam virtutis efigiem animo atque mente conciperent?». Não era decerto a mesma fé: «Vix credibile est, cum fides haec, quam oratione complectimur, sit firma mentis assentio, verbis divinis adhibita; eos fuisse hac fide stabilitos, ad quos nunquam legis divinae fama pervenit. Num natura tantum duce, quam unam in vita maxime sequebantur, veram virtutem assecuti sunt?». Guiados pela lei natural estavam próximos da doutrina cristã, tema que teólogos como Rahner têm investigado com reconhecida acuidade.

A essência da justiça é abordada no 1. 5: «Si igitur iustitia est summum et altissimum divinae gratiae beneficium, ea manque ad Dei similitudinem proxime accedimus, et omni studio in immortalitatem rapimur; si ea continet in se omnem pulchritudinis et honestatis excellentiam, ita ut nos De gratos, amabiles, atque iucundos efficiat; si mentem divina quadam specie informat et omnes einim partes ordine, lege, atque ratione constringit; si haec omnia recte gratiae quae nobis per Christi virtutem et gratiam inest, attributa sunt: ipsa profecto iustitia gratia putanda est; et non alia gratia ingenio fabricanda».

Nos 1s. 6 a 10 Osório trata com pormenor dos bens resultantes da justiça, dos bens concedidos aos primeiros pais, de uma opinião acerca da mente de Deus, da predestinação e, finalmente, da formosura e utilidade da justiça e da sua essência. De sublinhar que o 1.7 foi expurgado nalgumas partes como vem registado pelo Index de 1581.

Concluindo este despretensioso trabalho, diremos que, embora em Portugal a Contra-Reforma tivesse mantido um acentuado predomínio no campo religioso e deixado a sua marca na mentalidade geral, não deixa de ser 
importante e recomendável acompanhar o que se está passando no diálogo luterano-católico que coloca não poucos problemas que exigem reflexão.

Não podemos manter uma atitude de alheamento porque afecta o continente a que pertencemos e o mundo em geral, já que com as missões as duas partes ganharam forte implantação por esse mundo fora e tiveram uma grande influência em qualquer sociedade. Celebrar Lutero e as suas 95 teses é um momento que importa acompanhar e viver como uma efeméride singular. Dela podem extrair-se não poucas lições e ensinamentos que, à luz dos sinais do tempo que vivemos, podem iluminar o homem a reflectir sobre os inalienáveis valores da pessoa humana como a verdade, a justiça e a paz.

\section{Bibliografia}

\section{Obras de carácter geral}

Concilium Tridentinum. Diariorum, Actorum, Epistularum, Tractatuum nova collectio (19632001). Görresgesellschaft. Freiburg i. Br: Herder, 13 ts.

Corpus catholicorum (1919). Münster: Aschendorff, 114 ts. Nota: a Gesellschaft zur Herausgabe des Corpus Catholicorum e.V., além de Werke katholischer Schriftsteller im Zeitalter der Glaubensspaltung, edita também obras sobre Katholisches Leben und Kirchenreform, Reformationsgeschichtliche Studien und Texte e Vorreformationsges- chichtliche Forschungen.

Denzinger, Heinrich (2005). Kompendium der Glaubensbekenntnisse und kirchlichen Lehrentscheidungen, ed. e trad. P. Hünermann, Freiburg i. Br.:Herder etc. 40a ed. (DH).

Lexikon für Theologie und Kirche, AA. VV. (1993-2001). Freiburg i. Br., 10 ts.

Theologische Realenzyklopädie, AA. VV. (1977-2004). Berlin/Nova Iorque: Walter de Gruyter, 36 ts. +6 supl. (TRE).

\section{Reforma}

Bäumer, Remigius (1981). “Johannes Cochläeus (Dobenek) (1479-1552)”, in TRE 8, 140146.

Bekenntnisschriften (Die) der evangelisch-lutherischen Kirche (2010). Göttingen: Vandenhoeck \& Ruprecht, 13.a ed. (Bekenntnisschriften der evangelisch-lutherischen Kirche (BSLK). Nova ed. por Dingel, Irene, ed. (2014).

Beutel, Albrecht, ed. (2010). Luthers Handbuch. Tübingen: Mohr. 2. a ed., UTB 3416.

Burger, Christoph (2014). Tradition und Neubeginn. Martin Luther in seinen frühen Jahren. Tübingen: Mohr Siebeck, Spaätmittelalter, Humanismus, Reformation 79.

Confessio Augustana (1930). Das Augsburgische Bekenntnis (1530). Lateinischer Text, CA in BSLK, 31-137. Göttingen: Vandenhoeck \& Ruprecht. 
Dingel, Irene - Jürgens, Henning P., ed. (2014). Meilensteine der Reformation. Schlüsseldokumente der frühen Wirksamkeit Martin Luthers. Gütersloh: Güttersloher Verlag-Haus.

Ebeling, Gerhard (1971-1985). Lutherstudien. Tübingen: Mohr Siebeck, 3 vols. em 5 ts.

Formula Concordiae. Solida Declaratio de 1577 (BSLK 829-1100) (FC SD).

Martin Luthers Werke (1883-2009; 1912-1921; 1930-1985). Kritische Gesamtausgabe (Weimarer Ausgabe), Weimar (WA).

Köpf, Ulrich (2015). Martin Luther. Der Reformator und sein Werk. Stuttgart: Reclam.

Lutero, M. (1545). Vorrede zum ersten Bande der Gesamtausgaben seiner lateinischen Schriften. Wittenberg 1545 (in WA 34, 337; WA 54, 186, 3.8-10.16.18).

Melanchton, Philipp (1521). Loci commvnes rervm theologicarvm, sev hypotyposes theologicae. Coloniae Agripinae: Caesar, Konrad - Heinrich von Neuß.

Pesch, Otto Hermann (2004). Hinführung zu Luther. Mainz: Grünewald.

Schwarz, Reinhard (2015). Martin Luther - Lehrer der christlichen Religion. Tübingen: Mohr Siebeck.

\section{Diálogo ecuménico}

Apostolizität (Die) der Kirche (2009). Studiendokument der Lutherisch/ Römisch-katholischen Kommission für die Einheit. Paderborn/ Frankfurt: Bonifatius/Lembeck.

Herrenmahl (Das) (1978). Bericht der Gemeinsamen Römisch-katholischen/Evangelisch-lutherischen Kommission (Herrenmahl (Das) (1978).

Bericht der Gemeinsamen Römisch-katholischen/Evangelisch-lutherischen Kommission. Dokumente wachsender Übereinstimmung (DWÜ), 271-295. Paderborn: Johann-Adam-Möhler-Institut für Ökumenik.

Jenett, Ralf (2002). Heubtartikel christlicher Lere: Melanchthons deutsche Fassung seiner Loci theologici, nach dem Autograph und dem Originaldruck von 1553. Leipzig: Evangelische Verlagsanstalt.

Kirche und Rechtfertigung (1993). Das Verständnis der Kirche im Licht der Rechtfertigun- gslehre. Bericht der Gemeinsamen Römisch- katholischen/Evangelisch-lutherischen Kommission. Ibid., III, 317-419.

Lutherischer Weltbund/Päpstlicher Rat zur Förderung der Einheit der Christen, Gemein- same Erklärung zur Rechtfertigungslehre (1999). Gemeinsame offizielle Feststellung. Anhang (Annex) zur Gemeinsamen offiziellen Feststellung, Frankfurt/Paderborn.

Meyer, H. - Urban, J. - Vischer, L., ed. (1983). Dokumente wachsender Übereinstimmung. Sämtliche Berichte und Konsenstexte interkonfessioneller Gespräche auf Weltebene 19311982. Paderborn/Frankfurt (DWÜ I).

Meyer H. - Papandreou, D. - Urban, H. J. - Vischer, L., ed. (1982-1990). Dokumente wachsender Übereinstimmung. Sämtliche Berichte und Konsenstexte interkonfessioneller Gespräche auf Weltebene, t. II:. Paderborn/Franckfurt: (DWÜ II). 
Meyer, H. - Papandreou, D. - Urban, H.J. - Vischer, L., ed. (2003). Dokumente wachsender Übereinstimmung. Sämtliche Berichte und Konsenstexte interkonfessioneller Gespräche auf Weltebene, t. III: 1990-2001. Paderborn/Franckfurt: (DWÜ III).

Mostert, Walter (1991). “Luther III”, in TRE 21, 567-594.

\section{Contrarreforma}

Andrade, Diogo de Paiva de (1562). Concio habita ad Patres in concilio Tridentino congregatos, ab Illustri atqv Rever., Dominica secunda post Pascha A. MDLXII, Dom. Didaco De Payva, d'Andrade, Lvsitano, [Sacrae Theologiae Doctore]. Brixiae: Apud Johannem Baptismam Bozolae.

Id. (1564). Orthodoxarvm Explicationvm Libri Decem. In quibus omnia fere de religione capita, quae his temporibus ab haereticis in controversiam vocantur, aperte \& dilucide explicantur: Praesertim contra Martini Kemnicij petulantem audaciam...: Cum neceßarijs indicibus, rerum, verborum...: Coloniae Agripinae: Cholinus.

Id. (1565). Introdução em 18 páginas ao livro de D. Fr. Bartolomeu dos Mártires Stimulus pastorum. Lisboa: Apud Franciscum Corream Typographum Cardinalis Infantis.

Id. (1566). De Societatis Iesv Origine. Libellvs. Authore D. Iacobo Payua Lusitano, ac Sacr[a] $e$ Theologice Doctore, contra Kemnicij cuiusdam petulante $[m]$ audacia $[m]$ Doctore, contra Kemnicij cuiusdam petulante $[m]$ audacia $[m]$. Lovaina: Velpius.

Id. (1578.1580). Defensio tridentinae fidei catholicae et integerrimae quinque libris comprehensa. Adversus Haereticorum detestabiles calumnias, et praesertim Martini Kemnicij Germani. Olyssipone: Ant. Riberius; Coloniae Agripinae: Maternus Cholinus.

Cathechismus Concilii Tridentini (1566). Romae: apud Paulum Manutium.

Cochlaeus, Johann (1523). Adversus cucullatum minotaurum Vuittenbergensem, de sacra- mentorum gratia. Criminationes Lutheri, quibus ex ordine hic respondetur, particulatim singulis responsionibus ex industria praetexuimus. Coloniae Agripinae: Eucharius Cervicornus.

Id. (1549). Commentaria Ioannis Cochlaei, de Actis et Scriptis Martini Lutheri Saxonis: Chronographice, Ex ordine ab Anno Domini MDXVII, usque ad Annum MDXLI, Inclusive, fideliter conscripta; Adiunctis Duobus Indicibus, \& Edicto Vuormaciensi. Apud S. Victorem prope Moguntiam.

Eck, Johann (1554). Enchiridion locorum communium adversus Lutherum et alios hostes Ecclesiae (1525-1543) (Corpus Catholicorum, 34).

Index de l'inquisition portugaise 1547, 1551, 1561, 1564, 1581 (1995), vol. IV da série Index des livres interdits, dir.J. M. De Bujanda. Sherbrooke: Centre d'Études de la Renaissance.

Jedin, Hubert - Iserloh, von Erwin - Glazik, Josef (1985). Reformation - katholische Reform und Gegenreformation. Freiburg i. Br. - Basel - Wien: Herder.

Lortz, Joseph (1933), “Zur Lutherforschung”, in Historisches Jahrbuch. 53.

Id. (1964). Geschichte der Kirche in ideengeschichtlicher Betrachtung, t. 2: Die Neuzeit. Münster: Aschendorff. 
Mostert, Walter (1991). "Luther III", in TRE 21, 567-594.

Osório, D. Jerónimo (1592). Opera omnia. Hieronymi Osorii nepotis canonici Eborensis diligentia in unum collecta, \& in quattuor volumina distribute. Romae: ex bibliotheca Georgij Ferrarij, 1592.

Osório, Jerónimo (homónimo e sobrinho) (1611). Paraphrasis et commentaria in Ecclesiasten, nunc primum in lucem edita. Eiusdem Paraphrasis in Canticum Canticorum, et in ipsam recens auctae Notationes. Lugduni: Sumptibus Horatii Cardon.

Osório, D. Jerónimo, (1996). Tratados da nobreza civil e cristã. Trad., intr. e anotações de A. Guimarães Pinto Lisboa: Imprensa Nacional-Casa da Moeda.

Id. (1999). Tratado da justiça. Trad., intr. e anotações de A. Guimarães Pinto. Ibid.

Id. (2002). Tratado da verdadeira sabedoria. Trad., intr. e anotações de A. Guimarães Pinto. Ibid.

Id. (2009). Opera omnia, I: Paráfrases a Job e à Sabedoria de Salomão, vol. IV de Portugalliae Monvmenta Neolatina. Estabelecimento do texto latino, intr. e notas por A. Guimarães Pinto. Imprensa da Universidade de Coimbra - Universidade do Algarve.

Peter Fraenkel (1979). Corpus catholicorum, 34, Münster: Aschendorf, 27. 1536.

Pinho, Sebastião Tavares de (1984). "Poética e Poesia em D. Jerónimo Osório”, Humanitas, vol. $35 / 36$.

Pinto, A. Guimarães (2011). Diogo de Paiva de Andrade. Antologia. Selecção, Trad, transcr., intr. e notas. Col. Novilatina 1. Lisboa: Esfera do Caos.

Rodrigues, Manuel Augusto (1976). "Algumas notas sobre a vida e a obra de Diogo de Paiva de Andrade”, Revista Portuguesa de História. Coimbra, t. XV, p. 303, n. 5, 301-327.

Id. (1977). "Diogo de Paiva de Andrade. IV centenário da sua morte”, Revista de História das Ideias, I, 1977, 237-286.

Id. (1983). “O Poema «Navigatio Lusitanorum» de Martin Chemnitius”, Boletim do Arquivo da Universidade de Coimbra, V, 67-88.

Id. (1977). "A oração proferida por Diogo de Paiva de Andrade no Concílio de Trento; Algumas notas sobre a exegese bíblica em Portugal no séc. XVI”, Revista Theologica, vol. 12, fasc. 1-4, Braga.

Id. (1985). "Die Polemik zwischen Paiva de Andrade und Martin Chemnitius". Colóquio sobre o 5. ${ }^{\circ}$ Centenário do Nascimento de Lutero. Herzog-August Bibliothek de Wolfenbüttel, 3-7 de Agosto de 1985. 



\section{RECENSÕES}





\section{Flores, Jorge (2015). Nas margens do Hindustão. O Estado da} Índia e a expansão mogol ca. 1570-1640. Coimbra: Imprensa da Universidade de Coimbra, 566 pp., ISBN 978-989-26-0976-8.

A obra Nas margens do Hindustão. O Estado da Índia e a expansão mogol ca. 1570-1640, recentemente editada pela Imprensa da Universidade de Coimbra, corresponde, em certa medida, ao aprofundamento e divulgação da dissertação de doutoramento de Jorge Flores, intitulada originalmente Firangistân e Hindustân. O Estado da Índia e os confins meridionais do Império Mogol (1572-1636), defendida na Faculdade de Ciências Sociais e Humanas da Universidade Nova de Lisboa, em 2004. Como o mesmo autor sustentou em outro texto, é pouco profícuo que teses de doutoramento conheçam publicação em formato semelhante ao que foram avaliadas. Ao invés, seria desejável tornar o texto legível, "adaptar esse mesmo texto aos interesses de um público específico, e às regras de um determinado mercado”. Apoiando-se em exemplos internacionais, registou ser "necessário transformar essas teses em livros", exercício que conheceu materialização na publicação desta obra ${ }^{1}$.

Dividido em onze capítulos, partindo do complexo conceito de "fronteira" (p. 38-47), Jorge Flores aponta como objetivo promover uma leitura sobre as imagens produzidas por portugueses e mogóis com base na evolução das suas relações e conhecimento mútuo, entre os anos de 1570 e 1640. Para esse fim, colocando os portugueses num plano semelhante aos demais povos da Ásia do Sul (guzerates, bengalis, rajputes ou decanis), foi intento do presente trabalho observar "o modo como - a partir de Goa e de outras «cidades-fronteira» sob domínio ou influência - incorporaram os mogóis na sua acção e no seu discurso" (p. 45) (capítulo 1).

Deste modo, assumindo os portugueses e os mogóis como principais interlocutores, a obra principia relatando a vitória de Zahiruddin Muhammad Babur contra os afegãos, em 1526, na batalha de Panipat, um momento de afirmação para a nova dinastia mogol. Em oposição, o Estado da Índia encontrava-se em fase de grande turbulência política, particularmente após a morte do governador D. Henrique de Meneses (1524-1526), no mesmo ano. Assim, ainda demasiado distantes a absortos em problemas internos, portugueses e mogóis procuraram definir as estratégias a adotar nos seus próprios territó-

Cf. FLORES, Jorge - «Como escrever» a história da expansão portuguesa. Consultado online a partir da página do Instituto de Investigação Científica Tropical. Disponível em: http://www2.iict. $\mathrm{pt} /$ ?idc=102\&idi=14256. Ultimo acesso: 15-10-2015. 
rios e contextos geopolíticos. Foi no contexto da ofensiva militar mogol sobre o Guzerate, em 1534, que estes povos estabeleceram os primeiros contactos. Humayun, filho de Babur, procurou seguir o intento expansionista do seu antecessor com menos sucesso. Após uma incursão no Bengala, em junho de 1539, foi derrotado por um exército afegão na viagem de regresso a Agra e, no ano seguinte, novamente. Como o Guzerate, também Bengala era um território de contacto frequente entre portugueses e mogóis. Daqui para frente, estes dois territórios em particular, bem como de Bijapur e de Ahmadnagar, funcionariam como pontos privilegiados de contacto e proximidade com os mogóis. Posterior, a capacidade de resistência destes sultanatos assumiu-se como uma importante barreira de manter as ofensivas mogóis distantes dos territórios sob o governo do Estado da Índia.

Fragilizado e derrotado, o imperador chegou mesmo a perder Deli, coração do império, em 1540. Este manteve-se sob o controlo efémero da dinastia Sur até 1555, data em que Humayun conseguiu conquistar Lahore, marcando o seu curto regresso ao poder. Veio a morrer no ano seguinte, tendo-lhe sucedido Akbar que retomaria a política expansionista do início do governo do seu antecessor (capítulo 2). Este imperador lograria mesmo conquistar Tanda, capital do Bengala, em setembro de 1574. Contudo, logo em 1579 assistiu-se ao recrudescimento de vários focos de revolta não só da parte de vários oficiais mogóis, suscitada por algumas reformas governativas e financeiras promovidas pelo imperador, mas também em territórios como Cabul e Guzerate que, novamente, se afastavam da autoridade de Akbar (capítulo 3). Esta dinâmica foi, aliás, frequente. Após uma ofensiva mogol sob os territórios meridionais do império, o afastamento das forças imperiais levava ao recrudescimento gradual de focos de resistência e ao enfraquecimento da autoridade do centro que, entretanto, devia prestar atenção às outras fronteiras.

Foi neste contexto que se operou a transferência da capital para Lahore, em 1585. Com morte do governador de Cabul, meio-irmão de Akbar, os mogóis temeram uma eventual ofensiva dos uzbeques que, desde há alguns anos, vinha consolidando a sua autoridade na Ásia Central. Ademais, a turbulência política que nestes anos se vivia no império safávida convidava a um ataque àquele território. A distância do imperador e dos focos de conflito ditou um empobrecimento dos relatos e das informações produzidas por portugueses sobre mongóis e em sentido inverso. Contudo, pela primeira vez, Goa começou a perceber a complexidade dos impérios asiáticos em que se incluíam otomanos, safávidas, uzbeques e mogóis, a par dos múltiplos sultanatos. Não obstante, a partir de 1590, a pressão dos mogóis voltou a sentir- 
-se sobre os portugueses. Neste contexto, a conquista de Orissa e Cinde, em 1592, levou a que, pela primeira vez, se analisasse em Goa e Lisboa a possibilidade de Akbar promover ataques a algumas praças portuguesas. Receio infundado neste contexto (capítulo 4).

Nos anos seguintes, Akbar promoveu um conjunto de ações nos sultanatos próximos de Goa. Foi exemplo da campanha militar em Ahmadnagar, em 1586, enquanto procurou manter uma ligação diplomática comprometedora com Bijapur. Como sempre sucedeu, os portugueses procuraram manter uma posição ambígua e que os favorecesse em qualquer cenário. Assim, enquanto promoviam um diálogo profícuo com Akbar, incentivavam os sultanatos a resistir à autoridade mogol e procuravam que se aliassem com este fim. Depois de um conjunto de vitórias militares, Akbar regressou a Agra em abril de 1601. Morreu em 1605 sem ter sido, ainda, o imperador que pode submeter à sua vontade os sultanatos da fronteira meridional do império mogol (capítulo 5).

Nos capítulos seguintes, esboçou-se um relato sobre a evolução do cenário político nos sultanatos do Decão através de personagens chave com particular relevância na ligação que mantiveram com esse território. Foi o caso de Khurram, futuro imperador, que em 1616 foi remetido à região com vista a submeter o território à autoridade mogol. Foi este príncipe que, em 1622 , se revoltou contra a autoridade do imperador Jahangir (1605-1627), tendo sido feito imperador passados seis anos, após uma conturbada evolução do cenário político (capítulo 6). Esta análise fez-se a par de uma certa problematização em torno da questão do sincretismo religioso de alguns oficiais e membros da família imperial mogol, bem como, os reflexos que tais eventos e a sua evolução tiveram nas fontes portuguesas. Ao mesmo tempo, analisaram-se momentos de particular tensão, como os que decorreram entre $1613 / 5$, consequência de um enfraquecimento gradual da autoridade do Estado da Índia perante uma pressão que conheceu renovada proporção, em todo o território, com a presença crescente de ingleses e holandeses principalmente (capítulo 7).

Igualmente, apresentou-se o quadro que conduziu à afirmação do príncipe Khurram, feito imperador em 1628 com o título de Shahjahan, após a morte de Jahangir no ano anterior e a imagem que este soberano colhia junto dos portugueses. Partindo deste ensaio, apresenta-se e problematiza-se em torno da questão da sucessão dos imperadores, nos conflitos familiares que, frequentemente, envolviam a sua morte e a instabilidade política que se proporcionava pela ausência de um poder forte e central (capítulo 8). Nesta nova cronologia, tornou-se evidente a importância e o interesse que os suces- 
sivos imperadores vão atribuir à participação ativa em redes de comércio, ao regresso de toda a corte mogol às práticas islâmicas mais ortodoxas e as suas implicações para os portugueses e os seus relatos (capítulo 9). Seria sob este forte governo que a autoridade dos mogóis sob o Decão assumiu um significado sem precedentes, evidente a partir de 1630. Partindo de um conjunto de práticas carregadas de simbolismo e de um forte dispositivo militar e beneficiando de algumas fraturas políticas locais, o imperador conseguiu submeter a larga maioria do território, até ao ano de 1636 (capítulo 10). Com a neutralização dos sultanatos de Ahmadnagar, Bijapur e Golconda, os mogóis voltaram a ocupar-se de forma mais direta das relações com os impérios vizinhos. Nesta nova conjuntura, os sultanatos deixaram de funcionar como formas de retenção do império mogol que os portugueses habilmente procuram manipular repetidas vezes. Ao invés, passou a temer-se a investida direta do imperador sobre as feitorais portuguesas. Contudo, a partir de 1640 surgiu um novo grupo que constituiu um importante polo de conflito e ameaça para portugueses e mogóis simultaneamente - os maratas. Foi neste contexto que o mapa e a evolução política da Ásia do Sul conheceram novos contornos e intervenientes que extrapolam o âmbito da obra em observação (capítulo 11).

Procurando fazer-se uma análise crítica da obra deve destacar-se, em primeiro lugar, o largo número de fontes consultado pelo autor que apenas foi possível com o apoio de instituições internacionais que permitiram a concretização do projeto, como o mesmo indica. São disso sintoma os 19 arquivos instalados em Portugal, Itália, Inglaterra, França, Espanha, Índia e ainda, no Vaticano, cuja documentação se utilizou para a preparação deste trabalho. Aos manuscritos seria necessário acrescentar o significativo número de fontes impressas divididas entre o mundo europeu e indo-persa. Creio, aliás, que o elevado grau de internacionalização do autor e da sua obra foi um fator essencial para a redação de um trabalho com uma abordagem tão ampla e diversificada.

Este estudo foi complementado por um conjunto de notas de grande qualidade para a abordagem dos vários assuntos que compõem o trabalho. Não só se referem quais os trabalhos mais significativos como, frequentemente, se dão informações sobre as várias edições e a pertinência de cada estudo para o tipo de abordagem que se procura fazer. Tendo como ponto de partida o objetivo de avaliar as imagens produzidas por portugueses e mogóis entre o período de 1570 a 1640, o autor fá-lo de facto, ao longo de todo o trabalho, recorrendo não só a cartas e crónicas portuguesas e árabes (note-se, novamente, a preocupação em conhecer os dois lados da "fron- 
teira”), mas igualmente a pinturas, análise dos objetos que compunham as embaixadas e as suas simbologias. Assim, após a afirmação de Shahjahan, foi apontado que o imperador procurou projetar a sua imagem utilizando várias ferramentas, incluindo a pintura. Dado o contexto, refere-se uma miniatura pintada por Bichitr, em 1631. Aqui, Akbar entregava a coroa diretamente a Shahjahan, sentado à sua esquerda, ignorando a figura à direita, Jahangir (p. 330). A capacidade de incluir as fontes materiais de natureza diversa com carga simbólica privilegiada continua a ser uma das maiores insuficiências das investigações histórica. Como o presente trabalho ilustra, a sua inclusão permite uma leitura mais completa das representações que se promoviam e dos significados associados.

Igualmente, tendo como ponto de partida perceber como "entre $1570 \mathrm{e}$ 1640, Goa lidou com a avassaladora progressão do império mogol para sul e em direção ao mar", procurando entender como "do lado português, mas também do lado mogos - se estabeleceu, imaginou e evoluiu a(s) fronteira(s) entre ambos" (p. 34), frequentemente, para benefício do leitor, extravasa-se este objetivo. Assim, a título de exemplo, do ponto de vista militar, a obra relata a importância de tesouros abundantes no mundo asiático para o recrutamento, manutenção e aumenta das hostes militares (p. 66-68); Na conjuntura da ofensiva mogol sobre o Decão na terceira década do século XVII e das fontes produzidas nesse contexto, o autor oferece uma leitura bastante pormenorizada sobre as chefias e os contingentes militares do Bijapur, em 1634, por exemplo, a prática de recorrer a empréstimos como forma de financiar estas guerras, a importância do clima no condicionamento no exercício da guerra, o tipo de fidelidade dos diversos grupos militares para com os seus lideres, a importância dos laços de parentesco, as estratégias de guerra, a importância da topografia e da posição das fortalezas em todo o Decão e o rendimento e pertença de cada uma destas fortalezas (p. 444-457).

Do ponto de vista económico, o Cinde configura-se como uma importante região produtora de têxteis com ligações privilegiadas com o Golfo Pérsico e com o Guzerate (p. 88- 90); Do ponto de vista diplomático e político pode conhecer-se como os ingleses observaram o conflito que envolveu portugueses e mogóis, com epicentro na captura de dois navios muçulmanos no porto de Surrate, em 1630 (p. 358-363); Igualmente, todo o cerimonial, simbologia e implicações da transferência da capital de Agra para Lahore, ordenada por Shahjahan, em 1638, conhece uma descrição bastante pormenorizada (p. 463-467). Do ponto de vista cultural, apresentou-se como o hábito de utilizar trajes portugueses foi comum, não só entre imperadores mogóis (como Akbar em 1539), mas também no Japão e na China, em rela- 
ção aos trajes do Tibete neste último caso (p. 108); Em outro plano, promoveu-se uma leitura sobre o sincretismo religioso de Akbar no seu contexto, implicações e motivações (p. 126-139; 172-180). Acrescente-se, aliás, que a presença de jesuítas na corte mogol representou uma fonte particularmente relevante para o conhecimento do mundo mogol; ainda, sobre outros tópico como o processo de "bengalização" dos portugueses evidentes no século XVII (p. 311-314).

Pelo que fica exposto, o propósito de promover uma observação sobre as relações luso-mogóis entre os anos de ca. 1570-1640 e a evolução das conceções de uns em relação aos outros, configura-se como tímido em relação ao resultado final. De facto, como se elucidou, frequentemente o texto aborda outras questões que não se ligam com esse propósito e que, por vezes, extravasam as próprias fronteiras da relação entre mogóis e portugueses. Este dado é claramente positivo do ponto de vista das informações que a obra fornece. Através da sua leitura, não se conhece apenas as relações luso-mogóis e as suas implicações, mas também se passa a deter conhecimento sobre toda a evolução política da Ásia durante a cronologia adotada, enquanto se apresentam vários elementos de cariz cultural, económico e militar (etc.), dos povos que habitavam este espaço. Constitui, por isso, um valiosíssimo contributo para todo o leitor que queira conhecer a presença que os portugueses mantiveram na Ásia do Sul desde as primeiras décadas até ao final do século XVII, com natural destaque para a cronologia apontada (ca 1570-1640).

KEVIN CARREIRA SOARES

Universidade de Coimbra - FLUC Kevincasoares@gmail.com 


\section{"La Universidad de Salamanca en el siglo XX" Constituit scholas fieri Salamanticae, ediciones Universidad de Salamanca, Salamanca, 2011, 101 pp., ISBN: 978-84-7800-844-5}

O livro que aqui apresentamos, a lembrar a "famosa arte da imprimissão", cujo colofão é um testemunho de verdade, integra-se nas celebrações grandiosas dos 800 anos da Universidade de Salamanca (1218-2018) e, em particular, na Colección VIII Centenario de que é a segunda publicação.

Coube ao Reitor D. Daniel Hernández Ruipérez prologar a edição, de imponente design, com palavras, por um lado, de orgulho pela magnífica e secular história da Universidade de Salamanca e, por outro, de esperança no compromisso inquebrantável com o futuro.

Por sua vez, o Professor José Luis Martín disserta, com a autoridade científica que todos lhe reconhecem, sobre a Universidade e o seu contributo pra um reino em expansão, enquanto o Professor Gregorio del Ser Quijano, igualmente catedrático, sob o mote "que aya escuelas en Salamanca" nos deixa, de forma acurada e judiciosa, algumas notas sobre a primeira documentação do Estudo Salmantino.

Trata-se de textos de introdução à $2 .{ }^{\text {a }}$ parte do livro constituída pela reprodução fac-similada e transcrição de uma dezena de diplomas, de 1243 a 1300, considerados as "pedras fundacionais" da Universidade. Mais de metade (6) são originais, em pergaminho, e ostentam ainda os selos de validação dos reis que outorgaram privilégios diversos aos mestres e escolares de Salamanca. É sabido que não existe documento de criação, mas não restam dúvidas de que foi o rei Afonso IX de Léon quem, entre outras versões, "llamó maestros muy sabios en las sanctas escripturas y establesçio que se fiziessen escuelas en Salamanca”.

Miguel Ángel Jaramillo Guerreira, Director del Servicio de Archivos é o responsável pela modelar apresentação dos documentos todos acompanhados de sumário, quadro de tradição e transcrição. As reproduções, de qualidade superior, dão-nos a conhecer o diploma todo, ou seja, o recto e o verso da folha de pergaminho. A edição em apreço honra a Universidade de Salamanca e todas aquelas que, como "mater", inspirou ou criou, com o selo do prestígio, no continente americano.

Ad multos annos. 


\section{Arellano, Ignacio (2015). Dando luces a las sombras: estudios sobre los autos sacramentales de Calderón. Madrid/Frankfurt: Iberoamericana/Vervuert, 257 pp., ISBN: 978-84-8489-882-5 (Iberoamericana), 978-3-95487-422-4 (Vervuerte)*.}

La presente compilación, como bien el título indica, nos ofrece una serie de trabajos fundamentales sobre el tema del auto sacramental de Calderón, a cargo del profesor Ignacio Arellano. Y ya por esta razón, por encontrarnos ante un conjunto de artículos firmados por uno de los grandes expertos en esta parcela concreta de la literatura aurisecular, sabemos de antemano que se trata de una publicación esencial; tampoco es casualidad que la obra de Arellano haya constituido el volumen número 100 de la prestigiosa colección de la Biblioteca Áurea Hispánica en la cual se inscribe.

Las investigaciones aquí recogidas ya han sido publicadas en revistas especializadas o volúmenes monográficos a excepción de dos: el primero es un ensayo teórico sobre el género sacramental en inglés y el segundo un estudio sobre los cuatro elementos en el auto La vida es sueño. De cualquier modo, la información al respecto viene recogida en la "Nota preliminar". En estas páginas también se explica la elección del título: es un verso perteneciente al auto El año santo en Roma, dentro de un fragmento del Amor dedicado al Hombre, en el que se narra cómo la alegoría sirve para alumbrar los conceptos religiosos y sacramentales que entre sus páginas se integran.

El artículo que da comienzo al volumen está dedicado a presentar los presupuestos teóricos básicos sobre este género teatral; podría compararse con la versión más extensa en castellano publicada por Arellano y Duarte (El auto sacramental, Laberinto, 2003). No obstante, ahora el público potencial se amplía con esta traducción y revisión del trabajo previo. Algunos de los apartados que incluye son: definición del género, asunto y argumento de los autos, los autos en el siglo XX, además de la clasificación y explicación de algunos títulos representativos, mientras se concluye el estudio con un apartado dedicado a la prohibición la representar autos por Carlos III en 1765.

Los siguientes tres epígrafes principales tratan sobre los temas clave de los autos sacramentales: agudeza, espectáculo y organización dramática.

El primero de ellos dilucida acerca de la inmensa capacidad de Calderón para imbricar los planos literal y alegórico de los autos a través de múltiples mecanismos como los personajes, las etimologías, continuas referencias reli-

* Este trabajo académico se ha llevado a cabo gracias a una ayuda postdoctoral de la Universidad Pública de Navarra. 
giosas... Un gran ejemplo de este quehacer teatral es el auto El día mayor de los días, en el que se expone el misterio de un grano que debe morir para dar fruto, estableciendo una alegoría con Jesucristo en la Cruz para lograr la redención humana. Arellano estudia es este artículo todos los artificios "de ingenio" que entran en juego para establecer el mundo simbólico de este pasaje neotestamentario. De igual modo se analiza este funcionamiento en el auto No hay más fortuna que Dios, haciendo énfasis, en este caso, sobre las nociones de justicia y discreción. El siguiente trabajo de investigación trata, además, de la presencia de cuestiones históricas en las piezas calderonianas (con precisión tituló el propio autor su primera edición de 1677 como Autos sacramentales alegóricos e historiales). Si en ocasiones han sido tachadas de obras literarias sin conexión con el mundo aurisecular en que se hallaban contextualizadas, ejemplos como El socorro general dan fe de que dicha acusación no es cierta, cuando en sus versos se recrea una lucha que puede ser identificada sin error con la guerra de Cataluña.

A continuación, Arellano examina los modos en que Calderón refleja esos dos visos, literal y alegórico, en la representación de los autos, y como pasa de una escenografía mimética a otra de carácter místico. Para reforzar los argumentos esgrimidos aporta numerosos ejemplos extraídos de autos como Las espigas de Ruth, El año santo en Madrid o El sacro Pernaso, donde como ejemplo de este mecanismo la montaña griega se transforma en la bíblica Sion.

El último apartado, y más extenso, está dedicado a cuestiones específicamente dramáticas: motivos, fuentes y tradiciones. Aquí se encuentra el ensayo inédito en torno al papel ejercido por los cuatro elementos en el auto La vida es sueño, importante conjunto que opera con frecuencia en las piezas de Calderón junto a otros como los pecados capitales, las cuatro partes del mundo, los vicios, las virtudes, etc. El investigador aporta extensos pasajes del texto calderoniano que ilustran cómo se organiza dramáticamente el cuarteto, apoyándose en la edición crítica realizada por Fernando Plata ${ }^{1}$.

A continuación, unas páginas en torno al motivo del viaje en los autos de Calderón, acercan dicha producción religiosa a la tan fructífera crítica sobre la literatura de viajes que se está publicando en la actualidad; aunque no pertenecen estrictamente al género, los autos contienen frecuentes elementos viajeros, representación del homo viator o la peregrinación. Arellano divide estos elementos en tres tipos: viajes relacionados con la mitología clásica, viajes misionales y destierros y peregrinaciones. A partir de esta clasificación, sitúa los autos pertenecientes a cada uno de los tipos y estudia el motivo del viaje en

Calderón de la Barca, Pedro, La vida es sueño, ed. Fernando Plata Parga, Pamplona/Kassel, Universidad de Navarra/Reichenberger, 2012 (vol. 79). 
cada uno de ellos con precisión y extensión, siendo este el trabajo más largo de toda la obra.

Le sigue un examen a la presencia de los emblemas en los autos de Calderón y su funcionamiento dramático, estableciendo un maridaje perfecto: "Por ser tan rico en conceptos visuales, el teatro alegórico está muy cerca de la literatura emblemática, esa combinación de un estampa, un mote y un verso explicativo" (p. 185, citando a Fothergill-Payne). Como forma de organización de todos los ejemplos de confluencia entre autos y emblemas Arellano los divide en bloques, lo que resulta a todas luces más operativo que la simple acumulación de muestras particulares. Así, nos presenta los casos en que emblemas relativos a la flora, la fauna o la mitología se insertan en los autos con una función dramática. Asimismo, se hace referencia a emblemas cristológicos, eucarísticos y marianos (p. 206) como la representación de Cristo a través del león, el cordero o el pelícano; pero también a aquellos que simbolizan las fuerzas malignas como el basilisco, el áspid o la hidra de siete cabezas. Un interesante estudio que muestra la fructífera relación entre estas dos tradiciones auriseculares, la emblemática y el auto sacramental, que han servido para transmitir de un modo visual (en imagen y representación respectivamente) complejos conceptos morales, filosóficos o religiosos.

A modo de cierre Arellano ofrece al lector un epílogo en el que pone de relieve la importancia del auto sacramental más allá de las coordenadas espacio-temporales en que fueron escritos. Si bien contienen aspectos propios del siglo XVII (Inquisición, Contrarreforma... ), la gran mayoría de ellos tratan de temas universales inherentes al ser humano: salvación, destino, libertad, corrupción o esperanza, por nombrar solo algunos de una amplia lista. Además, es necesario tener en cuenta que los autos de Calderón son las muestras más excelsas de este particular género dramático, que traspone de un modo dramáticamente magistral los grandes conceptos filosóficos o religiosos desde un plano literal hacia un universo alegórico. Por su riqueza y plenitud, tanto literaria como de espectáculo teatral, debemos admirarlos con entusiasmo, y así equipararnos a "los admiradores privilegiados como fueron Wagner, Goethe, Beckett, Camus o García Lorca...” (p. 237). El gran conocedor de los autos sacramentales de Calderón, el profesor Ignacio Arellano nos está ofreciendo las claves esenciales para su lectura e interpretación, de manera que ¿cuál es la razón para no iniciar ese viaje?

DAVINIA RODRÍGUEZ ORTEGA

Universidad Pública de Navarra davinia.rodriguez@unavarra.es 
Canavaggio, Jean (2014). Retornos a Cervantes. New York: IDEA-Instituto de Estudios Auriseculares, Colección "Batihoja" 14, 292 pp., ISBN: 978-1-928795-98-5

Retornos a Cervantes, obra de Jean Canavaggio publicada en $2014^{1}$ por el Instituto de Estudios Auriseculares (IDEA), es un volumen de la colección "Batihoja" que compila artículos varios, publicados por el autor desde el año 2000 en diferentes revistas académicas y volúmenes colectivos. El libro se divide en cinco apartados: "Cervantes en su vivir", "El teatro", "Las Novelas ejemplares”, "El Quijote” y "El Persiles”, más un epílogo sobre el humanismo de Cervantes, en los cuales se distribuyen diecinueve artículos del autor. La importancia de contar hoy con esta compilación de artículos es grande, y reside en la posibilidad que tiene ahora el lector de aproximarse a las reflexiones del afamado cervantista francés de un modo orgánico, conociendo su enfoque teórico, su postura ante el estudio de la vida y la obra, pero también ante la problemática relación entre ambas, al abordar un autor como Cervantes.

Así pues, Canavaggio parte de mostrar lo que llama los "claroscuros" de la vida de Cervantes, una vida, como señala el crítico, de difícil reconstrucción histórica, recreada a trazos por las ficciones de Cervantes o por documentos tan dudosos y dispersos como el mismo manuscrito de Cide Hamete. Ante esta problemática, Canavaggio advierte que no se debe caer en el peligroso, $y$ a veces reduccionista, terreno de la identificación del autor con sus personajes, ni atribuirle a este la ideología de aquellos, pues se terminaría perdiendo la posibilidad de apreciar uno de los grandes logros de la obra cervantina: su polifonía, y, al verla como algo meramente testimonial, se desdibujaría su estudio y su valoración como una construcción literaria, como un universo de ficción particular, aunque no aislado, con sus leyes propias y sus personajes individuales.

Sin embargo, Canavaggio se cuida mostrarse ante los lectores como un formalista y, en efecto, su interpretación de los textos en ningún punto puede ser tachada de descontextualizada. Su enfoque teórico no pretende negar el contexto del autor, tal como lo pone en evidencia el mismo hecho de dedicar un apartado de este volumen al estudio de la vida de Cervantes. El estudio de los textos de Cervantes que lleva a cabo Canavaggio remite a la España del siglo XVII, a los referentes textuales del autor y de su público y a sus

\footnotetext{
Esta publicación se encuentra disponible en Acceso Abierto en: http://hdl.handle.net/10171/38119
} 
experiencias, alejándose no sólo de las lecturas de la obra cervantina en clave testimonial, sino también de aquellas que pretenden ver en su trama o en sus personajes la encarnación de algunos valores e ideales absolutos que resultan ser de épocas posteriores.

En completa coherencia con tal enfoque teórico, está el artículo titulado "De lengua en lengua y de una en otra gente: las experiencias lingüísticas de Cervantes". En este texto Canavaggio muestra la posibilidad de la obra de aportar a la biografía y la posibilidad de esta de aportar a la comprensión de la primera, sin descontextualizar, pero sin perder de vista lo literario. En efecto, Canavaggio afirma que podemos hacernos una idea de los conocimientos lingüísticos de Cervantes a partir de la aparición de diversas lenguas en sus obras, y, con ello, de sus viajes y posibles experiencias, pero el crítico va más allá de lo testimonial y pone de relieve que la aparición de estas lenguas cumple una función fundamental en la obra, pues caracteriza a los personajes. En este punto, Canavaggio destaca que los personajes se alejan del Cervantes histórico, aunque sus conocimientos remitan a este, y sostienen diferentes y contradictorias opiniones sobre las lenguas y sus usos, opiniones que pueden ser entendidas a cabalidad remitiéndose al contexto del autor.

También en su aproximación al teatro cervantino, Canavaggio da cuenta de la fertilidad del análisis de la vida y la obra dentro de los límites propuestos. En efecto, estudia la producción dramática cervantina en relación con las prácticas de su contexto; así, hace énfasis en la particularidad que ofrece un teatro dado a la imprenta y, como lo diría su autor, "nunca representado", precedido de un prólogo que se dirige específicamente a lectores. Gracias al estudio del contexto, Canavaggio muestra que Cervantes en tanto dramaturgo puede ser leído como algo más que un precursor o un discípulo inferior a Lope de Vega, es decir, como un autor que se separa de unas prácticas establecidas y reivindica otros medios de difusión, como el creador de un teatro nuevo.

En esta faceta de la producción cervantina resulta igualmente fundamental la separación entre autor y personaje por la que aboga Canavaggio, pues en el teatro relativo a Argel coexisten personajes moros, judíos y cristianos que caracterizan al otro de diversas maneras. Canavaggio afirma entonces que, lejos de pasar a considerar a Cervantes como antisemita o algo por el estilo atribuyéndole los diálogos de los personajes, hay que tener en cuenta la diversidad de caracterizaciones, qué personaje caracteriza al otro, y qué función cumplen tales caracterizaciones, para apreciar la polifonía y la complejidad de sus obras. Esto no quiere decir, como el mismo Canavaggio se encarga de resaltarlo, que pueda atribuirse a Cervantes una filosofía de la 
tolerancia, pues con tales miras, afirma el crítico, se llega a forzar los textos para deducir de ellos un pensamiento moderno atribuido de antemano a su autor, en detrimento del estudio de la construcción literaria.

En la aproximación de Canavaggio a la narrativa cervantina resalta, también por la coherencia con su enfoque hermenéutico, la consideración de otro contexto, que no es ya estrictamente el histórico: me refiero al contexto de los referentes textuales. En efecto, el crítico estudia casos como el de la transmutación del tópico de los celos de un viejo casado con una joven, presente en el folclore, en El celoso extremeño, y, posteriormente, la reescritura de esta novela en el entremés de El viejo celoso. También este tipo de estudio se lleva a cabo con el Quijote; ante las lecturas románticas que olvidan a Sancho y pretenden ver a don Quijote como un símbolo del choque entre el ideal y la realidad, las cuales, en términos de Canavaggio, terminan convirtiendo al personaje cervantino en un mito o una imagen fuera del texto en el que existe, el crítico vuelve su mirada hacia la complejidad del escudero, y llama la atención sobre los referentes caballerescos que toma en cuenta Cervantes al escribir su obra. Así, rescata la comicidad de la obra y su carácter paródico, desdibujado ante un público ajeno tales referentes.

En el marco de la reflexión sobre la comicidad de la obra y su carácter paródico, sería interesante pasar a preguntarse, bajo la consideración de la especificidad de los personajes por la que aboga Canavaggio, si don Quijote, partiendo de lo paródico, se sale de lo predecible que habría en este género y excede el horizonte de expectativas de los receptores de su tiempo e incluso el de los demás personajes de la obra, como se muestra particularmente a partir de la Segunda parte. Canavaggio, aunque pone su énfasis en el rescate de la comicidad, parece dar algunas luces sobre tal estudio, al afirmar la imposibilidad de ver a este personaje cervantino como la encarnación de algún arquetipo de locura, con lo cual deja abierto un campo fértil de discusión académica.

Pasando al análisis del Persiles, resalta también la consideración del contexto textual: frente a la tradición de la novela bizantina, que remite a lugares exóticos, Canavaggio destaca la particularidad de una obra que remite a España, en muchos casos, a los mismos escenarios del Quijote. Así, el crítico da cuenta de cómo Cervantes reúne en el territorio español representado en esta obra una multiplicidad de personajes, situaciones y conductas, que crean un mundo complejo, en el que geográficamente no podría trazarse una línea divisoria entre bárbaros y civilizados, mostrando que la "barbarie" puede residir en un espacio cristiano y cercano al lector. 
En el epílogo de su obra, Canavaggio pone en evidencia la agudeza de su enfoque teórico sobre la relación entre autor, obra y contexto. En efecto, antes de abordar la discusión de si se puede o no considerar a Cervantes como un humanista, Canavaggio se remite al significado de 'ser humanista' en el contexto de Cervantes, y muestra que esto implicaba, en el siglo XVII, estudiar lenguas clásicas en las aulas universitarias, caracterización que no concuerda con la vida azarosa y el conocimiento lego que muestra Cervantes del latín en varias de sus obras, pero sí con la caracterización de algunos de sus personajes. Ya dentro de este margen, que excluye cualquier anacronismo de aplicar a la persona de Cervantes el término humanista con la significación que le damos hoy en día, afirma que, aunque en la novela surgen temas propios del humanismo renacentista como la relación entre cordura y locura, entre apariencia y realidad o entre poesía e historia, si se analiza la obra, sale a luz que esta no pretende ser la encarnación de ningún presupuesto teórico, de ningún constructo sistemático, sino que es una obra de ficción, con unos personajes perfectamente individuales, $y$, por tanto, complejos, que discuten y abrazan diferentes perspectivas sobre temáticas propias de su contexto.

Una vez recorridas las páginas de este volumen de Canavaggio, podemos afirmar que esta compilación de artículos que nos ofrece la colección "Batihoja" del IDEA, lejos de ser un collage de textos inconexos, nos da a conocer una postura hermenéutica muy coherente. Canavaggio nos lleva de la mano por las diversas facetas de la creación cervantina y por las posturas teóricas a partir de las cuales ha sido abordada, en un valioso diálogo académico que deja claro el aporte de un enfoque propio que revela su fertilidad, no sólo por las contribuciones que nos ofrece el autor en sus análisis, sino también por la posibilidad que tiene de ser aplicado en estudios futuros.

SARA SANTA A. 


\section{Pérez Martínez, Ángel (2012). El Quijote y su idea de vir-} tud. Madrid: Consejo Superior de Investigaciones Científicas, 280 pp., ISBN: 978-84-00-09562-8

El ingenioso hidalgo don Quijote de la Mancha muestra una vez más ser una novela inagotable tanto para la lectura como para la crítica, pues un lector atento como Ángel Pérez Martínez formado en la Filología y en la Filosofía nos entrega una nueva manera de acercarnos a la novela cervantina. Con $E l$ Quijote y su idea de virtud, Pérez muestra una vez más su fino y agudo análisis para trabajar una novela que ha sido abordada desde tantas perspectivas. Ya nos parecía que su entrega anterior El buen juicio en El Quijote era una reflexión inteligente y ahora con sus nuevas indagaciones nos muestra su habilidad para innovar que, en el caso de la crítica cervantina, es difícil.

La intención del trabajo queda descrita en la primera oración del trabajo: "analizar el concepto de virtud en El Quijote". Su propósito es especialmente válido, pues no pretende encasillar la novela cervantina en un tipo de estructura previa, sino más bien "interpretar lo que en El Quijote se dice y se realiza sobre estos temas".

La elección del tema -según propias declaraciones- obedece, en primer lugar, a que "la acción que el personaje desarrolla se puede interpretar en el sentido de la praxis aristotélica; es decir, en la línea de su propia perfección personal". En segundo lugar, a la estrecha vinculación entre la idea de virtud y las nociones éticas y conocer así el código moral de la época. Finalmente, es importante para Ángel Pérez abonar en el debate sobre la virtud en nuestra época.

La estructura del libro es clara: el primer capítulo está dedicado a la virtud y los cuatro siguientes a las llamadas "virtudes cardinales": prudencia, justicia, fortaleza y templanza.

La idea de virtud debe ser abordada a partir del pensamiento griego y del movimiento del personaje hacia el ideal de perfección: "La virtud o areté apuntaba hacia la concepción de la conquista del propio dominio personal, del señorío sobre uno mismo". En este primer capítulo, la aproximación a la idea de virtud se realiza desde la filosofía. Así los presupuestos platónicos contenidos fundamentalmente en La República, Menón, Protágoras; y los aristotélicos, en Ética Nicomaquea se entremezclan con los postulados de Werner Jaeger, R.E. Curtius, E. Auerbach, J.A. Maravall y C. Morón y, por supuesto, con ingentes ejemplos tomados de El Quijote. 
La idea platónica de virtud se vincula con lo bueno y poseer el todo que representa la virtud es también poseer cada una de sus partes y así llegar a la noción de excelencia. Pérez señala, además, que debemos a Platón la codificación de las que luego serían llamadas virtudes cardinales. Mientras que la virtud aristotélica se bifurca en dos grupos: las virtudes morales y las intelectuales.

Las ideas griegas son desarrolladas por Jaeger quien señala como clave de la pedagogía helena el concepto de Areté tanto en su vertiente física como espiritual, "dicha palabra no solo se refería a la formación del ideal humano en un sentido educador, sino que apuntaba al heroísmo como una clave de las cotas más altas de la existencia”. Ese es el concepto que mejor se adapta al ideal caballeresco representado por Alonso Quijano quien es el heredero del tema prototípico de la épica medieval descendiente de la épica griega. Para precisar esta vinculación, Pérez presenta los pasajes en los que el Caballero de la triste figura se refiere a los héroes griegos: Aquiles, Ulises, Héctor, Orestes.

La valentía, la sabiduría, el honor, la búsqueda de la belleza en su dimensión trascendente, el sentido del deber tan arraigado en Alonso Quijano configuran a ese ser que se ha esforzado por ser famoso y modélico, hasta casi convertirse en el arquetipo de la virtud misma. Tal postura vital trae consigo una honda impronta social que unida al pensamiento cristiano, que introduce innovaciones fundamentales sobre la idea del hombre y del cosmos, permite construir ese ser creado a imagen y semejanza de Dios. Tanto es así que Sancho Panza sugiere al Quijote convertirse en santos para alcanzar con mayor celeridad la fama (Don Quijote II- Cap. 8, p.691.3). Don Quijote responde a ello que su religión es la caballería, ese es su camino hacia la santidad.

Pérez asegura que Cervantes nos propone una "exploración sobre la condición humana a manera de un ensayo en acto, una especie de epistemología existencial y narrativa”. Asimismo, llama la atención sobre el hecho de que $E l$ Quijote es la historia del héroe equivocado, aquel que siempre yerra y lo hace desde las dimensiones más profundas de lo humano: visión de la realidad y de sí mismo, que no hubiera sido posible en una cultura sin los desarrollos sobre la virtud aportados por el mundo griego y el cristianismo.

Para cerrar este capítulo, Pérez presenta a las virtudes que desarrollará en los capítulos siguientes y asegura que "las virtudes cardinales son aquellas que se adquieren mediante las fuerzas naturales y las teologales se refieren directamente a Dios”. Al ser El Quijote una obra de carácter secular, la búsqueda del caballero estará más vinculada con el examen de las virtudes naturales, aquellas que están desconectadas de la trascendencia. Sin embargo, 
eso no impide que veamos al caballero de la triste figura también como un caballero cristiano.

El segundo capítulo está dedicado a la idea de prudencia, también llamada buen juicio, presencia de espíritu, sagacidad, sabiduría y con un conjunto de palabras contiguas: discreción, sensatez, cordura que calzan a la perfección con un caballero que "procura ser justo y prudente, templarse en los combates, defender a los humildes, amar fielmente a una sola señora... parece que relaciona su conocimiento de la realidad con miras a una acción efectiva, lo cual está precisamente vinculado con la prudencia”.

Según Ángel Pérez, la prudencia se halla presente como una constante en la novela dentro de la tensión entre locura (literaria, no patológica) y cordura. La palabra 'prudencia' y sus derivados: 'prudente' y 'prudentísimo' y las palabras asociadas al concepto: 'discreción', 'entendimiento', 'sabiduría' y 'razón' se encuentran en ingentes cantidades en las dos partes de la novela cervantina.

A la idea de prudencia se contrapone la gran imprudencia: leer indiscriminadamente novelas de caballería que hacen perder el juicio a Alonso Quijano y lo convierten en don Quijote de la Mancha. Asimismo, se contraponen también la prudencia de Sancho Panza, basada en la percepción de los sentidos, a la prudencia imperfecta originada por el engaño a los ojos de los trastocados sentidos del caballero de la triste figura.

El tercer capítulo está dedicado a la idea de justicia: "Don Quijote, el hombre loco que sale a campear caballerosamente, es un enamorado de la justicia”. La búsqueda de justicia en este mundo pareciera ser patrimonio de incomprendidos y señalados como desequilibrados; por tanto, don Quijote calza perfectamente con el paradigma.

Para fijar el concepto de justicia, Pérez se remonta a las nociones asociadas a la idea de justicia de los griegos: la armonía, la igualdad, proporción, consecución del bien y condición previa para la felicidad; y valorada por los romanos como ayuda eficaz para tranquilizar los espíritus, y querida por sí misma y por el placer que produce, requisito indispensable para la convivencia social. "Los griegos y romanos realizaron enormes aportes al desarrollo del sentido de la justicia, los primeros acentuando la reflexión y los segundos construyendo un sistema práctico de convivencia social". Luego, el pensamiento cristiano potencia el concepto. Así, San Agustín lo vincula con el orden general y precisa que sin el amor, la justicia sería imposible. Además, la justicia se enriquece con la misericordia y, en el Nuevo testamento, se vin- 
cula con el hombre fiel, equitativo, verdadero, honrado, correcto, civilizado, hospitalario, observador de las costumbres y las reglas. "El justo es íntegro y esa condición no es una categoría lograda de manera inmanente, sino que es otorgada por Dios". La perspectiva cristiana se enriquece con el humanismo y con la tradición jesuítica, sobre todo la de Alonso Rodríguez quien escribió Ejercicio de perfección y virtudes cristianas, obra que Pérez vincula estrechamente con las ideas de Cervantes sobre el tema.

Todas las ideas anteriores se comparan con aquella que aparece en $E l$ Quijote aplicada a un personaje loco e imaginativo que busca vivir en un mundo donde la justicia prevalezca.

Don Quijote se convierte en un agente de justicia, una suerte de iuris prudens, que quiere dar a cada uno lo suyo. Sin embargo, la justicia se halla profundamente unida a la capacidad de raciocinio y ese es el problema del caballero andante cervantino. Don Quijote trasmuta la realidad y confunde los contextos, de ahí la tergiversación de la justicia como se ve en el episodio de los galeotes.

El cuarto capítulo está dedicado a la idea de fortaleza, idea que se encuentra en la novela cervantina de forma paradójica -según asegura Pérez- pues Cervantes construye un personaje lleno de fragilidades: en lo físico, en lo psicológico, en lo espiritual; sin embargo, don Quijote se siente fuerte: cree en la realidad de su fuerte brazo capaz de enfrentar gigantes armados, por ejemplo. La fortaleza y el valor son condiciones indispensables para el ejercicio de la caballería. Don Quijote se siente así, pero en realidad, no ostenta esas condiciones, tiene más bien ingenio, característica propia de los letrados y no de los caballeros.

En general, históricamente, la fortaleza es una condición ligada a lo exterior, a los varones y a una edad determinada: la juventud que trae consigo el vigor viril; sin embargo, Aristóteles la relacionará con "la dimensión interior diciendo que el hombre fuerte es un hombre de corazón. El Estagirita coloca esta idea en una posición intermedia entre el temor y la temeridad". Así, la osadía que presenta la novela cervantina es aquella que mira a la muerte como posibilidad. Como en el caso de las virtudes ya antes mencionadas, la influencia del cristianismo es determinante en la presentación del concepto en la novela cervantina: la fortaleza viene de Dios y se obtiene por medio de la confianza. En El Quijote, la palabra aparece asociada al vigor y al esfuerzo y es una condición tanto externa: la caballería y el valor, todas las aventuras del Quijote son pruebas de fortaleza; como interna: la fortaleza espiritual de la que hace gala en repetidas oportunidades el Caballero de la triste figura. 
El capítulo final se dedica a la idea de la templanza, última de las virtudes cardinales. "Es el dominio de los sentidos mediante la razón”. ¿De qué manera podría manifestarse en don Quijote si es la imagen misma de la locura? Según Pérez, "la templanza debe entenderse en un doble sentido: el primero está circunscrito a la austeridad en lo corporal" y "el segundo sentido es más amplio y está ligado con el concepto griego de soprhosyne que significa la moderación que la razón impone en toda acción y es, precisamente, un tipo de cordura, el justo medio". Esta virtud, históricamente vinculada con el apetito concupiscible, también se vincula con las ideas de orden y regularidad. Aristóteles la aborda como moderación. Santo Tomás la vincula con la abstinencia, la sobriedad y la virginidad y estas son las ideas que pueden observarse en la novela. Así, el amor que don Quijote siente por Dulcinea es casto, una fidelidad interior que comprueba el bachiller Sansón Carrasco. La abstinencia no solo se refiere a la sexualidad, don Quijote es manso de actitud y frugal en su alimentación. Alonso Quijano es lo opuesto a la arrogancia y al exceso, su norte es la moderación y hasta la mortificación.

Finalmente, podemos asegurar que el objetivo anunciado en la primera oración del libro: analizar el concepto de virtud en el Quijote se cumple a cabalidad. El recorrido por las virtudes cardinales al que Ángel Pérez Martínez nos invita a atravesar resulta gratificante.

Inteligente, intuitivo y de cuidadísima prosa El Quijote y su idea de virtud se convierte en un libro fundamental en la copiosa bibliografía cervantina. Mientras se escriban libros como este, don Quijote seguirá cabalgando.

Martina Vinatea Recoba 
Calderón de la Barca, Pedro (2016). La banda y la flor, ed. crítica Jéssica Castro Rivas. Madrid/Frankfurt am Main: Iberoamericana/Vervuert, 326 pp., ISBN: 978-84-8489-9051

La publicación de la edición crítica de La banda y la flor, comedia palatina, se inscribe en el proyecto de edición de las Comedias completas de Calderón de la Barca emprendido por el Grupo de Investigación Siglo de Oro (GRISO) de la Universidad de Navarra, dirigido por el profesor Dr. Ignacio Arellano. Constituye este libro, pues, el número 14 de esta serie que, además, participa de la fundamental colección Biblioteca Áurea Hispánica de la Editorial Iberoamericana/ Vervuert. Sin duda, esta novedad editorial, a cargo de la Dra. Jéssica Castro, implica un importante y significativo avance en los estudios auriseculares por cuanto explora uno de los más interesantes territorios del universo cómico calderoniano: la comedia palatina, subgénero dramático con frecuencia dejado de lado en los acercamientos al rico y polimorfo corpus del gran dramaturgo barroco español. La edición en cuestión consta de un riguroso y acertado análisis literario de la comedia, junto con la anotación filológica, el estudio y fijación textual de la misma.

Tanto la autoría como la datación de la comedia no suponen mayor complejidad; la pieza fue escrita y representada en 1632, fecha que aparece históricamente vinculada al interior de la obra por medio de la inserción de una extenso romance en la primera jornada, que relata la ceremonia de la jura del Príncipe de Asturias Baltasar Carlos, hijo de Felipe IV. Castro Rivas realiza un minucioso estudio de este fragmento para establecer el interesante contexto histórico de producción de la comedia, observando el proceso estético de exaltación política de la monarquía de los Habsburgo, y cotejando el texto histórico calderoniano con otras obras que narran el mismo acto oficial, tales como diversas crónicas y-de manera más dilatada- el auto sacramental de Mira de Amescua, La jura del Príncipe. La relación de la jura dentro de La banda y la flor, entonces, le sirve a Castro en igual medida para, por un lado, determinar las insoslayables circunstancias históricas de la composición y montaje de la pieza teatral, y por otro lado, examinar su particular función en el interior de la ficción dramática.

Como adelanté antes, quizás el aspecto más relevante y sustancial del estudio literario de La banda y la flor que ofrece Castro Rivas sea el análisis de la obra a la luz de su inequívoca adscripción al subgénero de la comedia palatina. Así pues, la editora parte por la delimitación de los rasgos propios 
de este tipo de comedias, siguiendo, y a la vez ampliando, las productivas conceptualizaciones sobre el mismo asunto que han tratado Frida Weber de Kurlat, Miguel Zugasti, Joan Oleza, Eva Galar y Blanca Oteiza, entre otros. A partir del deslinde del sistema genérico áureo propuesto por Marc Vitse e Ignacio Arellano entre comedias serias y comedias cómicas -diferenciación fundada en la predominancia del efecto estético trágico o cómico-, Castro inscribe la palatina dentro del segundo campo, elaborando un detallado recorrido por su conformación histórico-dramática y examinado su evolución desde el teatro de Lope, pasando por Tirso, hasta su culminación en Calderón, teniendo siempre a la vista la dinámica y compleja relación entre práctica escénica y teorización en la preceptiva aurisecular - del Pinciano a Bances Candamo-. Asumiendo entonces dicho enfoque en el análisis del género, Castro Rivas traza la trayectoria evolutiva de la comedia palatina para señalar algunas de sus convenciones estructurantes en la obra de Calderón, las cuales pueden sintetizarse en la localización de la acción en coordenadas espacio-temporales alejadas de la familiaridad española-castellana (países exóticos e intemporales); personajes pertenecientes a la alta nobleza (condes, duques, príncipes, etc.) en concordancia con el espacio dramático eminentemente palaciego -de ahí la denominación-; la presencia de los vectores temáticos del amor, la amistad, el matrimonio, los celos, el secreto y el silencio; la «generalización del agente cómico» (aplicando lo que Arellano observaba en las comedias de capa y espada); la profusa utilización del mecanismo del enredo en la trama; el efecto de inverosimilitud; y, en suma, la dominante tonalidad cómica y lúdica de las piezas. Todo esto Castro lo pormenoriza y ejemplifica adecuadamente a lo largo del corpus completo del subgénero cómico palatino calderoniano.

De esta manera, queda de manifiesto al lector el marco genérico que determina la producción dramática, la recepción estética y el horizonte de expectativas de los espectadores coetáneos. La editora, así, entrega una imprescindible y útil perspectiva teórico-práctica de análisis para abordar las obras de este tipo, que sin duda servirá para las aproximaciones críticas futuras de los estudios calderonianos. Posteriormente, y con suma coherencia, Castro pondera La banda y la flor bajo el prisma que antes proyectó. La trama de la comedia se hilvana alrededor de los lances amorosos entre el galán Enrique y las hermanas Lísida y Clori, con la intervención del amigo del galán, Otavio, el Duque de Florencia y el padre de las damas, Fabio. El enredo se va intensificando por medio de la acumulación de equívocos típicos de las obras cómicas: ocultamientos, identidades veladas o fingidas, cartas, duelos que no se consuman, el matrimonio que ordena el caos de la intriga, etc. Perfecta- 
mente resumen la construcción lúdica del enredo amoroso y las disyuntivas risibles estos versos en boca de Enrique:

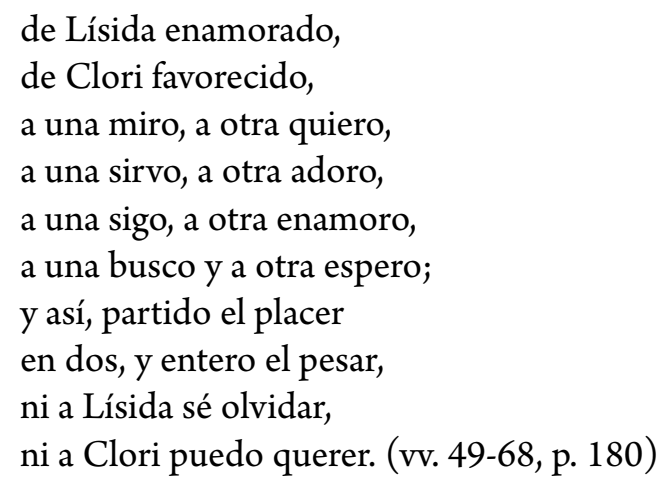

El galán, atrapado entre el favor de Clori y su amor hacia la hermana de la dama, Lísida, se verá luego enfrentado al «duelo de amor y amistad» (v. 669, p. 209) con su amigo Otavio; y para rematar la confusión cómica, aparecerá la intervención decisiva del Duque de Florencia, que introduce la lealtad como tercera fuerza movilizadora de la acción y la intriga. Dice Enrique sobre esta tríada central en el clímax del conflicto cómico:
¿Quién en el mundo pudo
$\tan$ fuerte lazo dar, tan fuerte nudo
de lealtad, de amistad y amor testigo,
de un señor, de una dama y un amigo? (vv. 1419-1422, p. 244)

Amor, amistad y lealtad hacia una dama, un amigo y un señor, en suma, configuran la entretenida trama de La banda y la flor. Otros elementos de la obra que Castro sopesa pertinentemente en su estudio literario son la localización de la historia -en la distanciada Florencia-, y los valores simbólicos de los colores azul y verde en relación, respectivamente, con la banda y la flor -objetos escénicos que dan título a la comedia- y su engarce con los celos y esperanzas de Clori y Lísida en un perfecto juego calderoniano de derivaciones y simetrías. Destaca, en este panorama, el énfasis que pone la editora en la relevancia que tienen los personajes femeninos en la consecución de la risa cómica o la presencia de la ingeniosidad risible apreciable, por ejemplo, en los estupendos versos del gracioso Ponleví: «^Ay, que me matan/ diez puñales de cristal/ con diez remates de nácar!» (vv. 1764b-1766, p. 260). Todo lo cual se inscribe coherentemente en la perspectiva genérica de la comedia palatina. 
La última dimensión que aborda el estudio literario que precede al texto de la comedia es la recepción de la obra. Castro indica la fortuna escénica de la pieza desde su inmediata representación hasta el siglo XX. En territorio español, nota la editora la escasa documentación sobre las puestas en escena realizadas durante el XVII, donde luego de su primer montaje en 1632, tuvo que esperar hacia el final del siglo para ser repuesta con mayor frecuencia en las tablas (1680, 1686, 1687 y 1692). El XVIII, a diferencia de lo se ha dicho, recibió con numerosos aplausos la obra calderoniana, al menos hasta antes del término del siglo cuando decae su popularidad. La banda y la flor en ese periodo se presentó tanto en los corrales madrileños del Príncipe y de la Cruz - con treinta y cuatro representaciones- como en otros teatros de las ciudades de Barcelona, Valencia, Sevilla y Valladolid. Con posterioridad, entrado ya el siglo XIX, la obra perderá vigencia en los recintos teatrales -se documentan solo ocho representaciones-, llegando al siglo XX que, a pesar de ver el rescate de la figura y dramaturgia de Calderón y su enaltecimiento en clásico, no registra ninguna puesta en escena de la comedia.

En el ámbito europeo, Castro Rivas señala una temprana traducción de la pieza palatina al francés en 1661, que acompaña el éxito del dramaturgo en esa lengua durante el XVII. Dos siglos después, La banda y la flor ingresará a la escena teatral alemana a través del movimiento romántico, que tan notablemente revitalizó la representación, lectura y valoración del arte de Calderón. La importante traducción de A.W. Schlegel -en el primer volumen de su Spanisches Theater en Berlín, 1803- sirvió para la difusión de la obra en tierras germanas. Otros hitos importantes de La banda y la flor en Alemania, nuevamente de mano del romanticismo, fueron la lectura que hizo Goethe de la obra y la ópera Liebe und Eifersucht (Amor y celos) compuesta en 1807 por E.T.A. Hoffmann -refundición de la versión de Schlegel-, que lamentablemente nunca vio su materialización en la escena. Castro también informa sobre la breve presencia del texto en Inglaterra y su viaje hacia tierras americanas, donde se tiene noticia de al menos tres presentaciones en Ciudad de México en los postreros años del siglo XVIII.

Pasando ahora al apartado del estudio textual, la editora reconstruye las vicisitudes de la transmisión de la obra, constituida principalmente por textos impresos: la mayoría corresponden a ediciones sueltas pertenecientes a los siglos XVII y XVIII, y otros son versiones contenidas en partes de comedias. Son diecisiete testimonios en total, dieciséis de ellos impresos, y uno es un manuscrito bastante tardío, de 1831. Según Castro, la edición princeps correspondería a la Parte Sexta de Comedias varias de diferentes autores impresa alrededor de 1654, la cual posee tres diferentes impresiones (PE1, PE2 y 
PE3). En 1668 se publica la Parte Treinta de Comedias nuevas y escogidas de los mejores ingenios de España, en donde aparece una versión de la comedia con el título alternativo Hacer del amor agravio. Vera Tassis publica en 1684 la Octava parte de comedias del célebre poeta español don Pedro Calderón de la $B a r c a$, en la que se incluye esta comedia palatina. Luego del examen detenido de la historia textual de la comedia, y tras efectuar el correspondiente análisis de las variantes, Castro Rivas decide tomar como texto base a PE1 por ser el que presenta mayor autoridad textual, aunque enmendando sus errores y lagunas con PE2 y Vera Tassis cuando estos ofrecían una lectura mejor. A esto añade un estema de la probable transmisión textual. La anotación del texto de La banda y la flor, siguiendo las normas editoriales del GRISO, comprende notas de tipo textual -que explican enmiendas hechas sobre el texto base, donde se indica y justifica su procedencia- y notas de tipo filológicas -que iluminan tópicos, motivos y alusiones literarias, generalmente con ejemplificaciones de otros usos en pasajes calderonianos u otros autores contemporáneos-. Es de resaltar que el aparato de notas que incluye la editora equilibra con pertinencia el esclarecimiento de diversos pasajes, su relación con el corpus calderoniano y el trabajo de fijación del texto.

En fin, esta valiosa edición crítica de la comedia palatina La banda y la flor de Calderón de la Barca supone una importante contribución al actual crecimiento del campo de estudio del universo cómico calderoniano, en sus variadas y polisémicas vertientes. La consistente propuesta interpretativa de la editora indica la vigencia y productividad de las lecturas cómicas de obras eminentemente cómicas -valga significativamente la redundancia-. Así, teniendo como sustrato del análisis las coordenadas y convenciones genéricas palatinas, Jéssica Castro Rivas ha logrado ampliar y enriquecer las aproximaciones al sistema teatral aurisecular. A su vez, el prolijo estudio y fijación textual aportan una edición filológica utilísima e ineludible que de seguro servirá para futuros trabajos sobre esta comedia y el género palatino. En síntesis, la fructífera labor calderoniana del Grupo de Investigación Siglo de Oro de la Universidad de Navarra tiene, en concordancia con su proyecto editorial, un sólido nuevo ejemplar disponible para los atentos lectores.

ARIEL NÚÑEZ SEPÚLVEDA 


\section{Cátia Salvado Fonseca (2015). Uma família de fotógrafos. Car- los e Margarida Relvas. Lisboa: Chiado Editora, 427 pp., ISBN: 978-989-51-2646-0}

A fotografia divulgou-se na sociedade burguesa e industrial oitocentista não apenas como um processo técnico revolucionário de registo imediato e mecânico de aspectos da realidade, mas também como um novo meio de comunicação social, transmissível a longa distância. De acordo com Paulo Baptista, os finais do século XIX e os inícios do século XX correspondem a uma verdadeira "idade de ouro" da fotografia em Portugal (BAPTISTA 2013: 95), quer ao nível das inovações técnicas, quer no domínio dos processos fotomecânicos que permitiram assinaláveis qualidades de impressão. Neste período, a arte de fotografar assume também particular relevância no contexto dos lazeres dos grupos sociais mais elevados, entretecendo novas formas de relacionamentos no círculo familiar ou dos amigos mais chegados.

O livro da Mestre Cátia Salvado Fonseca intitulado Uma família de fotógrafos. Carlos e Margarida Relvas, editado pela Chiado Editora, aborda todas estas questões e oferece-nos uma viajem aos primórdios da fotografia no nosso país ao tomar como tema central de estudo o universo familiar de um dos mais fascinantes e emblemáticos pioneiros portugueses da fotografia, o aristocrata e gentleman farmer Carlos Relvas. Para nos conduzir, a autora empreendeu um rigoroso trabalho de selecção, leitura crítica e interpretação das fontes (impressas, fotográficas e iconográficas), de modo a compreender o singular universo do distinto fotógrafo amador, suas influências e originalidades, e a descortinar a individualidade artística da sua aprendiza, a filha Margarida Relvas, obrigada pelas forças das circunstâncias e dos preconceitos do seu tempo a permanecer na sombra do pai. Se é costume ouvir-se dizer que por detrás de um grande homem se esconde uma grande mulher, também parece ser verdade que o brilho da genialidade das grandes figuras ofusca e reduz a meras silhuetas as mulheres artistas do seu entorno... Situação comum no século XIX, durante o qual se considera que a marca distintiva da mulher é a penumbra e a discrição...

O livro reproduz, com ligeiros acrescentos, a Dissertação de Mestrado de Cátia Salvado Fonseca, realizada no âmbito do Mestrado de "Museologia e Património Cultural" da Faculdade de Letras da Universidade de Coimbra. Estrutura-se em quatro capítulos, sendo completado por uma introdução, em 
que é feito o enquadramento geral do tema, e uma conclusão, a que se segue a listagem das principais fontes e da bibliografia consultadas, bem como um corpo significativo de anexos, constituídos por quadros recapitulativos e reproduções de documentos de diversas tipologias: correspondência epistolar, plantas de edifícios e, acima de tudo, fotografias. Muitas e belíssimas fotografias!

No primeiro capítulo, Cátia Salvado Fonseca começa por abordar o desenvolvimento da fotografia no século XIX, suas etapas e o contributo dos principais pioneiros da arte fotográfica (Nièpce, Daguèrre, Disdéri, entre outros), detendo-se também na sua recepção no nosso país e na sua utilização para fins científicos. Recorre-se à sua aplicação nas principais escolas superiores, como apoio de novas e velhas ciências (a medicina, a zoologia, a geografia, a agronomia, a antropometria criminal...), no registo de cartas militares ou como fonte documental dos patrimónios arquitectónico e folclórico. No momento em que a fotografia se convertia num verdadeiro objecto social, como qualificam alguns autores, multiplicam-se, a partir da segunda metade do século, os ateliers dos fotógrafos nas principais cidades do país. Cátia Fonseca acompanha esse desenvolvimento e procede à sua cartografia, dando-nos a conhecer os primeiros salões fotográficos. O desenvolvimento da fotografia na segunda metade de oitocentos coincide com o período de emergência da burguesia comercial e industrial, iniciado sobretudo com a Regeneração, sendo imediatamente apropriada como um importante papel na construção da sua identidade e memória. O desejo do retrato e o construção da autoimagem acompanham a ascensão da burguesia oitocentista, o que contribuiu significativamente para a sua difusão, tornando-se o retrato fotográfico a principal actividade comercial ligada à nova arte.

No segundo capítulo intitulado "Carlos Relvas: um fotógrafo de dimensão internacional”, Cátia Salvado Fonseca traça a biografia do famoso aristocrata fotógrafo, realçando a sua curiosidade intelectual e a instrução eclética, proporcionada por consagrados mestres em áreas específicas como a música e a arte equestre. Associaria o desenvolvimento dessas capacidades artísticas à gestão das suas vastas propriedades agrícolas, como gentleman farmer que era. Foi na juventude que se iniciou na arte fotográfica, provavelmente através de Wenceslau Cifka, o primeiro fotógrafo a instalar um estúdio fotográfico em Portugal, no ano de 1848. Aperfeiçoaria a técnica mediante o estudo, como o comprova a vasta biblioteca especializada existente na actual Casa-Estúdio Carlos Relvas, na Golegã, mas, acima de tudo, através da prática experimental, nos estúdios que construiu na sua casa, devidamente ade- 
quados à execução fotográfica. Ainda muito jovem participa em exposições, como fotógrafo amador, tanto em Portugal como no estrangeiro, tornando-se rapidamente num nome conhecido. Fotografa monumentos, tipos regionais, animais, pessoas, enfim, como então se dizia, "vistas e monumentos". Um tema se destaca, desde cedo, na sua vasta panóplia temática: a sua terra, a Golegã do seu coração, a qual ganha protagonismo no panorama nacional e internacional, pela via do seu fotógrafo, sendo tão ou mais conhecida do que outras localidades portuguesas. Carlos Relvas põe, literalmente, a sua terra natal no mapa, conseguindo, inclusive, por essa via, uma nova configuração da justiça concelhia, ao transferir-se a sede da comarca da Chamusca para a Golegã. Com toda a propriedade, Cátia Salvado Fonseca afirma com clareza na pág. 74: "É neste sentido que se pode afirmar que a fotografia tem para Carlos Relvas uma intenção política, servindo objectivos mais profundos de descentralização, bem caros ao espírito republicano”. Por outras palavras, a fotografia é utilizada como um instrumento desafiador de legitimidade, sendo portadora de rupturas nos campos político e social. Trata-se, sem dúvida, de um ângulo insólito de análise, a merecer reflexões mais aprofundadas.

No $3^{\circ}$ capítulo, o mais longo, o tema principal centra-se na análise do empenho e da criatividade colocada por Carlos Relvas na edificação do seu segundo estúdio fotográfico, nos anos 1880 , convertido mais tarde na sua residência, após o segundo casamento, ao qual imprimiu as características de um templo austríaco ou suíço, como esclarece Cátia Salvado Fonseca. Neste capítulo, a autora detém-se com detalhe, mas sempre problematizando, nos pormenores da construção, nos poliédricos estilos que configuram o edifício como uma construção única e singular, nas inovações técnicas e estéticas, nas afinidades com pormenores concretos de monumentos nacionais, no recurso a novos materiais e a tecnologias de ponta concretizado numa aproximação aos sectores mais desenvolvidos da indústria nacional do tempo. Com perspicácia e sensibilidade, Cátia Salvado Fonseca capta o esforço do aristocrata em procurar dar à fotografia um estatuto artístico e industrial e propõe-nos uma leitura intertextual e interpretativa dos objectivos de Carlos Relvas. Construir "Um monumento dedicado à ciência, à técnica, à arte e à indústria" (p. 103) afigura-se ter constituído o seu propósito, como nos esclarece a autora deste livro, acompanhando o impacto do novo edifício nos media do tempo, onde recolheu preciosos testemunhos. A terminar o capítulo, a autora debruça-se sobre as alterações sofridas no atelier na sequência da sua conversão em residência e em Atelier-escola. Também Carlos Relvas não escapou à moda dos ateliers-escola (de fotografia, de pintura, de escul- 
tura...) que, nos finais do século XIX, se propagam nas principais cidades do país, a exemplo do que se fazia no estrangeiro, e que constituem uma alternativa às carências do ensino artístico formal.

"A filha: Margarida Relvas, fotógrafa” é o assunto desenvolvido no último capítulo. Inicia o tema pela problematização da arte no feminino e do estatuto da mulher autora e/ou artista, demonstrando as múltiplas dificuldades de afirmação das mulheres nestes campos, no decorrer de oitocentos, sendo tolhidas por preconceitos sociais, estigmatizadas pelo discurso científico, com a medicina à cabeça, que não lhes reconhecia qualquer capacidade criativa e espírito crítico, sendo ainda desvalorizadas pela opinião pública, não obstante ligeiros progressos, com reflexos sensíveis na instrução feminina ou mesmo na sua aceitação em escolas ou ateliers de artistas, como alunas. Jovem da alta sociedade ribatejana, Margarida Relvas tem uma educação adequada ao seu estatuto e lugar social. Em casa, aprende música, línguas estrangeiras, desenho, a comportar-se em sociedade ou inicia-se nas causas filantrópicas, sendo preparada para vir a desempenhar os papéis adequados a uma dama do seu nível, como esposa, mãe e "senhora de casa", como então se dizia. O elemento que rompe com esta educação tradicional é a aprendizagem da arte fotográfica, ministrada pelo seu pai, desde tenra idade, tendo-lhe, inclusive, disponibilizado um pequeno laboratório fotográfico, em casa. Desde muito cedo, criança ainda, viaja com o pai, acompanhando-o e participando, autonomamente, como amadora, em concursos e exposições fotográficos ou em revistas da especialidade. A sua sensibilidade artística destaca-se pela forma como retrata paisagens, reflectindo a influência do pictoralismo ao incorporar códigos da pintura, o que a distingue da obra artística do seu pai e a singulariza como fotógrafa. Num texto com sabor a poesia, Cátia Salvado diz-nos que, para Margarida Relvas, "a fotografia assume o papel de telas desenhadas por um olho mecânico" (p. 324). A sua actividade como fotógrafa termina abruptamente quando casa. Tinha 19 anos de idade. A partir dessa data, perde-se o rasto da fotógrafa e emerge a esposa e "senhora de casa".

Uma breve conclusão remata a obra, sintetizando alguns dos aspectos já desenvolvidos nos capítulos anteriores, mas pondo sobretudo em evidência o modo como Carlos Relvas, através da fotografia, projectou internacionalmente o país e promoveu a difusão do património português (paisagístico, monumental e/ou etnográfico). Simultaneamente, Cátia Salvado Fonseca singulariza a obra de Margarida Relvas como fotógrafa, conferindo-lhe o estatuto de autora. A fotografia afigura-se ser para os Relvas da Golegã, uma arte que se aprende em família, estando, por isso, 
destinada a perpetuar-se... E como se espera que um livro que versa sobre a fotografia, as tenha, a autora também as disponibilizou, enriquecendo o volume e descansando o olhar.

Em suma: um livro cativante, pela variedade dos assuntos abordados, pelo equilíbrio entre a profundidade e a clareza do texto, pela imagem e pelo acabamento de qualidade, mérito da Chiado Editora, o que o converte numa obra acessível e seguramente agradável a um vasto público. Um livro a ler, pois, com prazer e proveito.

\section{Bibliografia}

BAPTISTA, Paulo - "Fotografia", Dicionário de História da I República e do Republicanismo. vol. I: A-E. Lisboa: Edição Assembleia da República - Divisão de Edições, 94-100.

IRENE VAQUINHAS

Universidade de Coimbra - FLUC / CHSC irenemcv@fl.uc.pt 


\section{Sarmiento de Gamboa, Pedro (2015). Sumaria relación, ed. Joaquín Zuleta Carrandi. Madrid: Iberoamericana, 336 pp., ISBN: 978-84-8489-889-4 (Iberoamericana), 978-3-95487- $-427-9$ (Vervuert)}

Pocos trabajos de edición y crítica pueden ser tan engorrosos como los de las crónicas indianas. Quien lleva a cabo esta tarea debe enfrentarse con un sinnúmero de obstáculos de fijación textual, cotejo de ediciones, problemas historiográficos, discusiones sobre la autenticidad del relato, criterios tanto históricos como literarios que deben estar presentes en su análisis, etc. Indudablemente, la publicación de estas crónicas presentadas fidedignamente en su forma original y acompañadas de un estudio íntegro es una labor, no solo de varios años por parte de un académico, sino de varios estudiosos que, a lo largo de siglos, enriquecen, esclarecen y corrigen en nuevas ediciones que, más que pretender ser definitivas, introducen al lector en un diálogo crítico con el texto, que de esta manera logra ensanchar sus límites.

Este tipo de publicaciones nos ofrece Joaquín Zuleta Carrandi en una nueva edición de la Sumaria relación de Pedro Sarmiento de Gamboa por la editorial Iberoamericana. Sarmiento es un autor que, pese a sus pocas ediciones circulantes, aporta de manera significativa a la reconstrucción de uno de los momentos más singulares de la historia magallánica.

Vale rememorar la figura de este insigne y desdichado explorador gallego. Parte muy joven a probar suerte en Indias y se instala durante muchos años en el virreinato del Perú, donde cumple por un tiempo el oficio de cartógrafo y observador de las culturas indígenas. El año 1597 es enviado por el virrey Francisco de Toledo a acabar con las correrías del corsario Francis Drake por las costas chilenas. Sarmiento de Gamboa parte en su búsqueda hacia el estrecho de Magallanes, donde además debía rastrear la existencia de algún poblamiento inglés en los canales australes. Puesto que esta búsqueda fue infructuosa, cumplió con una segunda orden encomendada: explorar este territorio e informar directamente al rey Felipe II de las posibilidades de levantar fortificaciones para controlar el paso por el estrecho.

En 1580 se reúne con el rey en España, quien finalmente decide organizar la Armada del Estrecho de Magallanes, cuyo propósito era la fortificación y poblamiento del estrecho, de manera que este paso quedase asegurado para los intereses de España y de Portugal, reino próximo a ser anexado por su matrimonio. Este proyecto fue un inmediato fracaso, pues la mayor parte 
del ingente de navíos y tripulación naufragan y desertan antes de llegar a su destino. Así, Sarmiento de Gamboa apenas logra fundar dos poblaciones miserables en el estrecho, que tendrán poca duración.

Una vez fundados estos poblados, Sarmiento de Gamboa parte rumbo a España, pero es capturado varias veces hasta que en 1590 logra retornar a España y allí da cuenta al rey de su empresa en el mencionado documento, la Sumaria relación.

Sarmiento de Gamboa demuestra en esta crónica un manejo considerable del lenguaje con un estilo sobrio y preciso, muy consciente de las exigencias del género de una relación objetiva de los hechos que se conjuga con un discurso persuasivo bien disimulado y calibrado. Esta edición extrae y comenta los elementos más llamativos en la retórica del autor y así establece una línea discursiva coherente que dialoga con la verdad histórica.

La principal contribución del editor al estudio de este texto, es el trabajo comparativo que realiza con otros testimonios de esta exploración que muchos otros tripulantes también documentaron, como también las versiones de corsarios ingleses que debieron enfrentarse a la Armada del Estrecho. Así, se nos ofrece una reconstrucción de los hechos mediante el cotejo de documentos que se encontraban dispersos en distintos puntos geográficos, realizando un importante progreso en el estudio histórico de estos eventos. Los testimonios complementarios se integran de manera crítica en la edición, poniendo en discusión la historicidad de momentos específicos de la crónica y proporcionando una interesante consideración del punto de vista en este extraño género de escritura.

También de suma importancia resulta el trabajo de fijación textual que Joaquín Zuleta llevó a cabo, pues mediante una revisión acabada del manuscrito y de sus variantes posteriores logra resolver varios problemas de la transmisión textual que se advierten desde el manuscrito original, el que fue intervenido por el historiador Martín Fernández de Navarrete a fines del siglo XVIII, haciendo más arduo el posterior trabajo filológico.

La crónica está acompañada por un completo trabajo de anotaciones que, además de dar cuenta del proceso de fijación y cotejo, ofrece un amplio trabajo de esclarecimiento léxico y gramatical del texto, muchas veces exponiendo distintos trabajos hermenéuticos para una correcta interpretación semántica de particularidades que afectan imperceptiblemente a la comprensión de los hechos.

A este documento se integra un extenso trabajo crítico, que incluye una biografía del cronista y un amplio contexto histórico expuestos a partir de numerosas fuentes biográficas. Luego el editor se explaya en el estudio textual 
de la obra, donde da cuenta del texto original y de las variaciones, ediciones y estudios que ha suscitado hasta nuestros días. Finalmente, incluye numerosos anexos entre los que se encuentra una cronología, ilustraciones facsimilares y cartográficas, glosarios, índices, e incluso un catálogo pormenorizado de las naves que compusieron la Armada del Estrecho. Todos estos apéndices permiten extender los alcances del documento en cuanto se inserta de manera significativa en los eventos históricos y en el contexto sociocultural. Así, el interés por el documento se amplía más allá de su contenido autónomo y permite una entrada eficaz en su momento histórico.

En suma, el editor añade a la crónica un extenso estudio y exposición de todos los temas concernientes al documento y su composición, de manera que esta edición ofrece los elementos necesarios para llevar a cabo un estudio académico completo de la obra, pero también proporcionando las nociones básicas para aquellos que se introducen en la lectura de crónicas indianas. Las anotaciones y estudios, aunque precisos y profundos, no pierden la claridad en sus ideas y se exponen de manera muy accesible.

Este libro no pretende entregar una edición definitiva de la Sumaria relación, ni su estudio busca zanjar las discusiones alrededor de esta crónica, ni la documentación histórica que añade intenta fijar la veracidad de los hechos ni abordar cada arista de estos eventos; ciertamente, todas estas pretensiones serían ilusorias en torno a cualquier texto de esta índole. Pero decididamente el libro se acerca a una perspectiva más o menos completa del texto, proporcionando los elementos suficientes para una comprensión cabal del documento.

Con esta primera publicación editorial de una crónica por parte de Joaquín Zuleta, queda demostrada la eficacia de su trabajo y espero que el reconocimiento de su labor filológica impulse la concreción de nuevos proyectos editoriales en los próximos años.

JosÉ TOMÁs FuenZALIDA

Universidad de los Andes jtfuenzalida@miuandes.cl 


\section{Fernández López, María (Marcia Belisarda) (2015). Obra} poética completa, Estudio, edición y notas de Martina Vinatea Recoba. Nueva York: IDEA-Instituto de Estudios Auriseculares, Colección “Batihoja” 16, 2015, 483 pp., ISBN: 978-1-938795-03-9

Desde 2011 el Instituto de Estudio Auriseculares (IDEA) lleva a cabo con excelencia diversas actividades para fomentar y consolidar los estudios sobre el Siglo de Oro hispánico: la publicación de la revista digital Hipogrifo. Revista de literatura y cultura del Siglo de Oro, la publicación de las colecciones «Batihoja»y «Peregrina», y la realización de congresos por todo el mundo. En pocos años, «Batihoja» ha impreso cerca de una veintena de volúmenes, entre estudios, ediciones críticas y reproducciones facsimilares, que circulan entre especialistas, pero están disponibles en Acceso Abierto (Open Access) para el público interesado en la literatura hispánica de los siglos XVI y XVII. Con el número 16 ha aparecido recientemente la excelente edición de la Obra poética completa de Marcia Belisarda que, hoy, gracias a las investigaciones de la editora, Martina Vinatea, podemos identificar como María Fernández López.

La literatura moderna hispánica, tanto en Europa como América, ha incrementado favorablemente su número de ediciones críticas y estudios gracias al trabajo de instituciones como el GRISO, IDEA y el Centro de Estudios Indianos (hoy Proyecto Estudios Indianos). Sobre todo, debe resaltarse la apuesta por tópicos novedosos que, además de incorporar la producción de los virreinatos americanos y europeos del Orbe Hispánico, se ha orientado hacia los escritos de comunidades tan relevantes como las religiosas. La monja fue la escritora típica de la modernidad europea e hispánica. La escritora presentada por Martina Vinatea resulta un hallazgo feliz para quienes estudian tanto las prácticas letradas de los conventos, como para el resto de especialistas en poesía del siglo XVII.

Este trabajo constituye en sí mismo un caso ejemplar para el estudio filológico de los textos de la Edad Moderna. El conjunto poético anotado y comentado viene precedido por un estudio histórico que comunica al lector tanto la importancia del material manuscrito con que se ha preservado la obra de Marcia Belisarda, así como el complejo entramado cultural y político que condicionó la producción de su obra.

La primera parte, «Estudio introductorio», muestra cómo la lectura diligente de los manuscritos (soporte de la mayoría de textos femeninos con- 
ventuales) es siempre el punto de partida más seguro para las indagaciones filológicas. Con una cumplida descripción del Ms. 7469 custodiado por la Biblioteca Nacional de España, la editora ha revelado un rico circuito literario propio de las comunidades femeninas toledanas en la primera mitad del siglo XVII. El hoy denominada Obra poética completa, además de parecer un legajo para la imprenta, revela con sus paratextos una intensa actividad entre los conventos toledanos. Marcia Belisarda es una escritora típica del siglo XVII que consiguió expresar su subjetividad a pesar de los múltiples encargos literarios que recibió para fiestas, acontecimientos privados e, incluso, la redacción de la Vida de la venerable madre María Bautista. Vinatea complementa un retrato de dicha comunidad letrada femenina con un útil catálogo de las escritoras toledanas cuya actividad comprende los años entre 1630 y 1670 (pp. 48-52).

El aporte más consistente del estudio preliminar es la reconstrucción de la biografía de la autora. Vinatea con pericia ha ordenado la información previamente consignada por biógrafos, antologadores y comentaristas de la obra de Marcia Belisarda (p. 54). Ella demuestra cómo la mayoría de estudiosos había seguido la información consignada por Manuel Serrano y Sanz en su estudio sobre escritoras españolas que cubre el período de 1401 a 1833. Su lectura nos recuerda la importancia que para un investigador tiene la suspicacia: si bien Marcia Belisarda habitó en el Real Convento de la Concepción de Toledo, esta no fue una monja concepcionista. Su lectura del manuscrito ha revelado que Marcia Belisarda era una comendadora de Santiago (pp. 55-61), basándose tanto en visitas y entrevistas a los conventos de la Concepción Francisca, de las Comendadoras de Santiago y archivos diversos, así como en el hallazgo de la Vida de la venerable madre María Bautista. Fue gracias a su comprensión cabal del material manuscrito que Vinatea constató que Marcia Belisarda es el seudónimo literario de la religiosa María de Santa Isabel que hoy, gracias a este estudio, sabemos que se corresponde con María Fernández López (pp. 61-62).

Aun cuando considera la hipótesis de Serrano y Sanz sobre la finalidad del manuscrito para la imprenta, su investigación revela una realidad más amplia y coherente con el entorno de producción (pp. 64-67). Ciertamente los poemas laudatorios que proemian los versos de Marcia Belisarda obedecen a los usos de los impresos modernos; pero, como recuerda la editora, la circulación de la poesía femenina conventual fue principalmente manuscrita. Ignorar la naturaleza material del conjunto poético nos alejaría más del texto. Este ya padeció una lectura desatenta y parcial desde la década de 1970; sería injusto ahora que se le niegue su naturaleza y la importancia de haber sido 
transmitido en un circuito letrado acostumbrado a la coexistencia entre la letra impresa y la manuscrita.

La descripción que Vinatea realiza del conjunto de poemas resulta tan útil como sus comentarios históricos y filológicos circunscritos a la naturaleza compositiva del documento toledano. Considerando las distintas modalidades que los libros de versos adoptaron desde inicios del siglo XVI, su estudio revela una vez más que las convenciones no son necesariamente las más seguras. Lo evidente hubiese sido ordenar el poemario a partir del binomio de literatura 'sagrada' y 'profana'; mas ella apunta a un orden mucho más sugerente $y$, al mismo tiempo, ajustado a la condición material del conjunto. Así, el libro es acomodado en función de las composiciones para ser cantadas en oposición a las que deben ser leídas (pp. 71-72). Esta división insiste en los aciertos de Vinatea cuando interpreta la información extradiscursiva: el talento poético de Marcia Belisarda, si bien expresó su idiosincrasia, fue también un don colectivo. Este manuscrito revela su participación en diversos acontecimientos propios del circuito letrado que la rodeaba.

Al cumplido catálogo de los tópicos tratados en los subconjuntos de poesía para ser leída y poesía para ser cantada (pp. 73-84), le sigue un esclarecedor apartado sobre los géneros líricos y combinaciones estróficas empleados por la poetisa (pp. 85-90). Con una clara preferencia por el romance, la poesía de Marcia Belisarda, según lo explica Vinatea, muestra una sugerente correspondencia con los tópicos tratados en la influyente obra de Alonso de Ledesma, cuyos Conceptos espirituales marcaron la temática de la lírica sacra del siglo XVII (pp. 91-93). Dicha constatación hecha por la investigadora, confirma el perfil que ha trazado para la escritora: la de una religiosa educada, integrada a diversos círculos letrados toledanos de la primera mitad del siglo XVII.

Por su parte, la 'Bibliografía' constituye un aporte sustancial para la comprensión tanto de la escritora como de su obra (pp. 97-110). Se trata de una excelente combinación de estudios que muestra cómo abordar de manera específica el texto trabajado: desde tratados y estudios filológicos, estudios sobre arte y religión, hasta investigaciones sobre la escritura femenina en la España moderna.

En la segunda parte del volumen, «Edición anotada del libro de poesías de María de Santa Isabel, Marcia Belisarda (SEUD.)», el lector encontrará una contribución igualmente notable. Vinatea explica que debido a la existencia de un solo testimonio manuscrito una edición crítica es innecesaria. Sin embargo, debe destacarse el óptimo trabajo paleográfico que ha llevado a cabo con el manuscrito, considerando que no todos los pasajes son de fácil 
lectura. Así, ha consignado las variantes respecto de transcripciones previas que de algunos poemas se han hecho en antologías; hecho que permite apreciar la calidad de su trabajo ecdótico.

La anotación de los textos consta de dos partes. Por un lado, está el comentario que dispone para los lectores la información necesaria para comprender tanto el contexto de producción como el de interpretación del poema en cuestión. Ahí la editora explica quiénes son los interlocutores o destinatarios del poema, cuáles son los referentes culturales o literarios (tópicos, intertextualidad con obras de otros autores, por ejemplo) y, sobre todo, una cumplida relación de los santos aludidos. Sobre este particular, Vinatea no se limita a señalar los relatos hagiográficos vigentes durante el siglo XVII, sino que además señala la relación intertextual entre los versos y la iconografía religiosa de los conventos toledanos. Además de varios lienzos de $\mathrm{El}$ Greco sobre santos y advocaciones de la Virgen, destaca particularmente la relación planteada entre el romance 74 dedicado «A la Magdalena» y un lienzo de mediados del siglo XVI. El comentario señala que dicho romance en cuartetas debe comprenderse como una écfrasis de La Magdalena recostada ubicada en el coro de la Iglesia de santo Domingo el Real de Toledo (p. 308). Igual atención merece el hallazgo de tres lienzos dedicados a san Bernardo de Claraval cuya relación se explica con los poemas 75, 76 y 77 (pp. 311-317).

Sin duda, los comentarios de la presente edición constituyen una primera exégesis difícil de superar. Gracias a la minuciosa exploración de la editora, los lectores, legos o expertos, cuentan ahora con la base necesaria para posteriores interpretaciones de los poemas. La relación que Vinatea ha propuesto entre varios de los poemas y lienzos específicos custodiados aún en conventos o iglesias toledanos abre nuevas posibilidades para el estudio de la poesía femenina. La historia del arte tiene en estos poemas valiosos documentos que constituyen primeras interpretaciones de los lienzos que los muestran tan como objetos de contemplación como dadores de significado.

Asimismo, las anotaciones que siguen al comentario resultan de gran utilidad. En primer lugar, se describe formalmente el poema (estrofa, tipo de rima). Luego, los versos son anotados a partir del léxico o a partir del sentido. Vinatea no se limita a exponer los tópicos más recurrentes de la lírica petrarquista de raigambre hispánica, sino que además detalla diversos conceptos que permiten una primera y segura interpretación del poema. Para ello se sirve de tratados teológicos, sermones, hagiografías y, desde luego, textos 
literarios que formaron parte de la comunidad letrada a la que perteneció Marcia Belisarda.

Los anexos del volumen incluyen la transcripción del expediente de limpieza de sangre y profesión de fe de sor María de Santa Isabel (pp. 475-480), y reproducciones de algunos folios manuscritos de la Vida de la venerable Madre María Bautista (pp. 481-483). Con ellos el volumen reconstruye la dimensión textual histórico-literaria de una escritora española del siglo XVII. Se trata de un valioso estudio que plantea un interesante modelo de trabajo para posteriores intentos de edición filológica del vasto y aún poco explorado corpus de escritoras modernas. Martina Vinatea abre un microcosmos poético, antes solo reservado para un grupo privilegiado de lectores, que hoy completa nuestra comprensión de la sociedad española del fascinante siglo XVII.

ELIO VÉLEZ MARQUiNA

Universidad del Pacífico velez_re@up.edu.pe 


\section{Solis, Yves; Savarino, Franco (Coord.) (2011). El anticlerica-} lismo en Europa y América Latina. Una visión transatlântica. México: Investigacion/Proa, 395 pp., ISBN: 978-607-484-234-0 (Escuela Nacional de Antropología e Historia), 978-972-836138-9 (CEHR-Universidade Católica Portuguesa)

A obra El anticlericalismo em Europa y América Latina. Una visión transatlântica, organizada por Yves Solis e Franco Savarino é uma produção coletiva que reúne parte das comunicações apresentadas na mesa-redonda cujo tema tratava do Anticlericalismo en America Latina, inserida no XV Congresso Internacional de La Asociación de Historiadores Latinoamericanistas Europeos (AHILA), que ocorreu em Leiden, Paises Baixos, nos dias 26 a 29 de agosto de 2008. A justificativa para a promoção do encontro e a publicação do livro repousa na constatação de que "a pesar de la importancia de este tema, al momento son muy pocas las investigaciones que incluyen uma visión 'global' y comparativa del fenómeno”. Por conseguinte, o argumento/objetivo central da obra é abordar/compreender o anticlericalismo "desde distintos ángulos y diversos lugares” (p. 5). Os coordenadores da obra são especialistas e membros do Seminario Internacional Iglesia, Estado y Sociedad Civil, criado em 2008, na Universidad Iberoamericana Ciudad de México.

O livro está dividido em três partes, distribuídos em onze artigos. $\mathrm{Na}$ primeira parte, denominado de "Asuntos Políticos", são analisados dois casos europeus (Itália e Espanha) e dois latino-americanos (Venezuela e México). O primeiro artigo "Libertad contra Verdad - Tensiones entre liberales y religiosos em la Venezuela del siglo XIX”, escrito pela socióloga Maria Eugenia Talavera, apresenta uma instigante investigação sobre o processo de laicização da nascente república venezuelana. A autora do artigo mostra que, com a independência da Venezuela do jugo da Espanha, os novos dirigentes políticos desejaram extirpar da sociedade a "consciência monárquica, fuertemente atada a la religión católica" (p.16). O auge do processo de laicização do Estado venezuelano ocorreu durante os dezoito anos "de conducción del país del general Antonio Gusmán Blanco", conhecido como o "guzmanato" (18701888). O processo de secularização de Gusmán envolveu a expropriação de bens da Igreja, extinção de conventos masculinos, dissolução das ordens e congregações femininas (1872) e o rompimento com a Santa Sé, assim como a proposta de criação da Igreja nacional Venezuelana. No entanto, o projeto não conseguiu ser completamente implementado, em boa medida em razão da diplomacia do papado e também pela resistência de setores ligados à Igreja 
católica. Com o fim do governo de Gusmán ocorreu uma "viraje em las relaciones entre La Igresia y el Estado” (p.38), onde o coroar dessa nova fase foi a retomada das relações com a Santa Sé e o retorno de diversas ordens religiosas no limiar do século XX.

O segundo artigo, "La "U" o los católicos y las sociedades secretas", assinado por um dos coordenadores da obra Yves Solis, estuda uma organização secreta intitulada de Unión de Católicos Mexicanos, mais conhecida como "U”, fundada em 1915. Analisar as características dessa organização e suas relações com a hierarquia da Igreja, tendo como documento básico as sessioni (atas das reuniões dos prelados solicitadas pelo Papa com a finalidade de resolver conflitos pontuais e urgentes das diferentes nações, documento sob guarda do Arquivo Secreto do Vaticano) é o objetivo central do artigo. A organização da "U" tinha como "missão" fazer uma reação radical ao anticlericalismo do Estado mexicano e implementar uma ordem social cristã. Exigia o segredo absoluto dos membros da organização e disciplina rigorosa. Essa organização procurou atuar em várias frentes: criação de semanários, escolas e, especialmente, na política com o propósito de "cambiar las leys y los gobiernos" (p.54). No entanto, a hierarquia da Igreja em Roma, em especial o delegado apostólico, temia que a organização fosse descoberta e trouxesse consequências para a Igreja e para a nação, além disso, a organização funcionava nos moldes da Maçonaria, o que trazia desconforto para a hierarquia eclesiástica. Aconselhado pela maioria dos cardeais, o papa Pio XI "condenou a associación”, decretando sua extinção (1922).

"Relaciones peligrosas: anticlericalismo, Iglesia y fascismo en Italia" é o título do artigo assinado por Franco Savarino, professor da Escuela Nacional de Antropología e Historia (México), também organizador da obra em análise. Savarino inicia o seu artigo afirmando que um dos assuntos menos conhecidos na história do anticlericalismo moderno foi a postura anticlerical do fascismo italiano nos anos 20 do século XIX. "Em realidad, el fascimo como fenómeno político-cultural de su época - fue para la Iglesia um desafio considerable, por su carácter ideológico laico-pagano y por su gran fuerza de seducción y de arraste entre las masas" (pp. 79-80). Utilizando como aporte teórico as ideias de Emilio Gentile, Savarino afirma que o fascismo foi uma religião política, nesse sentido concorrendo com o catolicismo. É perceptível no fascismo, além do jacobinismo do Risorgimento, características pagãs, sobretudo manifestado no culto ao Estado, prática denunciada pelo Papa Pio XI como uma "statolatría pagana" (p.85). Apesar das características citadas, os dirigentes fascistas aproximaram-se da Igreja Católica, pois percebiam que algumas características do catolicismo - como as noções de hierarquia, 
ordem, submissão, transcendência, assim como a noção de "bien comúm y el de corporación" - eram afinadas com a ideologia fascista. O Estado fascista, reconhecendo as funções civis da religião, incorporará o catolicismo dentro da religião de Estado. "Para ambos, tomar esta senda suponía aceptar unas relaciones peligrosas que podríam afectar el espiritu y el proyecto histórico da la religión política y de la religión tradicional" (p. 94). O autor conclui afirmando que a aproximação do Estado fascista à Igreja Católica era um “matrimonio de interesses", que culminará no Tratado de Latrão (1929) e um sólido apoio católico e eclesiástico ao regime fascista.

O caso do anticlericalismo na Espanha foi o último texto da primeira sessão, assinado por María Pilar Salomón Chéliz, da Universidade de Zaragoza, intitulado "Constuir la identidad nacional desde el anticlericalismo". Chéliz, argumenta que entre os diversos estudos que estabelecem a relação entre religião e nacionalismo, o caso espanhol está ausente. Em face dessa constatação, a autora propõe-se estudar a construção da identidade nacional espanhola a partir do anticlericalismo, em especial o de cariz republicano, que procurou criar a imagem de uma república laica e moderna. A autora reconhece que a obra seminal de René Remond contribuiu para impulsionar "el estudio del anticlericalismo en España sobre nuevas bases" (p.100). Segundo Chéliz, o anticlericalismo chega ao seu apogeu na Espanha no final do século XIX, os republicanos usaram o discurso anticlerical como argumento retórico na sua luta contra a tradição, representada pela monarquia e pelo clericalismo, onde "El anticlericalismo aparecía vinculado en ese discurso a la modernidad y la europeización, dentro de un esquema dualista y maniqueo establecido entre tradición y modernidad: la Iglesia y la monarquía simbolizaban la primera (...); la razón y la ciencia, por el contrario, encarnaban la segunda” (p. 106).

Rita Mendonça Leite no artigo "O anticlericalismo na óptica do protestantismo português" inicia a segunda parte da obra denominada Las cuestiones sociales. Na segunda metade do século XIX, o universo religioso português experimenta uma dinâmica de diferenciação religiosa, com a formação de comunidades cristãs evangélicas, contribuindo para o progressivo e demorado processo de pluralidade religiosa em Portugal. "Essas comunidades participavam então activamente da lenta estruturação do percurso que as conduziria da exclusão até a liberdade de culto" (p.133). Como? Durante o período da Monarquia Constitucional em Portugal o Estado era confessional, amparado por uma população majoritariamente católica, e refletia-se num Parlamento também de maioria católica. $\mathrm{O}$ texto de Mendonça Leite ressalta e analisa a importância qualitativa da minoria quantitativa evangélica. Os protestantes estavam situados num espaço "entre a criminalização, consignada na lei 
constitucional e penal, e a integração progressiva no seio da sociedade portuguesa" (p.117). Como mecanismo de integração, os protestantes desenvolveram espaços de sociabilidade e aproximaram-se metodologicamente dos republicanos. Deste modo, intervieram na sociedade através do ensino, da imprensa, conferências, atividades físicas e através da caridade. $\mathrm{O}$ anticlericalismo protestante estava integrado aos conteúdos teológicos e doutrinários das comunidades evangélicas, era perceptível na sua "construção de uma concepção sócio-cultural antagónica e alternativa ao catolicismo” (p.125). O tradicional antijesuitismo dos anticlericais liberais e republicanos também foi incorporado pelas comunidades protestantes, sobretudo "pelos obstáculos colocados [pelos jesuítas] à pluralidade religiosa e definição da liberdade de cultos" (p.129). Diante do consenso em torno da constatação "que Portugal se encontrava numa situação de crise", os protestantes responsabilizavam os católicos pelo estado do país, apoiaram os republicanos e defenderam a liberdade religiosa e política como caminho para o progresso e superação da crise.

"Entre revolucionarios y católicos: un proyecto de nación, 1913-1917", artigo da historiadora María Gabriela Aguirre Cristiani, analisa-se o anticlericalismo no início da Revolução Mexicana. Em 1911, Francisco Madero lidera um processo revolucionário que colocou termo ao governo ditatorial de Porfírio Diaz. No entanto, dois anos depois, Victoriano Huerta assassinou Madero e assumiu o comando da revolução. Os opositores de Huerta tornaram-se extremamente anticlericais por entenderem que a hierarquia católica apoiara a ação golpista, como consequência "o uso de la violencia fue uma constante" (p.158). No entanto, é importante "matizar que no todos los revolucionarios fueron anticlericales, y los que sí lo fueron lo manifestaron en distintos niveles" (p.159). O clero, nesse contexto, era retratado como "retardatário", "detestable", "un cancer" e deveria ser extirpados da sociedade. Outro aspecto importante no anticlericalismo mexicano estava associado ao fato de que a Igreja colocara em prática as diretrizes da encíclica Rerum Novarum (1892) do Papa Leão XIII, onde a nova doutrina social da Igreja, com sua aproximação às classes trabalhadoras, gerava temor e desconfiança por parte dos revolucionários e "este es probablemente el factor más importante del choque entre Iglesia y Estado em esos años" (p. 161). O programa do catolicismo social colidia com o projeto social revolucionário. A autora conclui afirmando que "el manejo de la 'cuestión social' por parte de la Iglesia influyó significativamente em el proyecto revolucionario, aunque ello significó la radicalización del anticlericalismo" (p. 171).

O cientista político Massino Di Giuseppe aborda o anticlericalismo no período de "institucionalização revolucionária" no México. No artigo "Las 
políticas de 'desfanatización' em el México indígena”, o autor procura traçar a "evolución de las políticas de desfanatización" efetivadas pelo governo federal do México durante o Maximato e a primeira parte da época cardenista (1928-1936). O objetivo central da Desfanatización, segundo Di Giuseppe, era enfraquecer a hierarquia da Igreja Católica e conquistar as mentes e os corações das populações indígenas e rurais, demasiadamente "fanatizadas" pelo clero católico. O presidente Plutarco Elias Calles envidou todos os esforços para secularizar a escola e difundir novos valores associados ao progresso e a modernidade. Na região de Tabasco, o governador Tomás Garrido Canabal, aplicou as ideias de Calles e liderou a mais radical experiência de "desfanatização" dessa época. Diversas medidas anticlericais forma colocadas em prática. No entanto, a resistência da Igreja católica e, principalmente, a oposição das próprias comunidades indígenas foram fundamentais para impedir o avanço desse movimento.

"Anticlericalismo y Cultura" é a terceira parte da obra está composta com quatro artigos. No primeiro texto "Anticlericalismo en el siglo XIX: el periódico El Libre Pensador (1870)”, a historiadora Nora Pérez-Rayón investiga a militância dos livres-pensadores contra o clericalismo na esfera pública mexicana. A autora desenvolve uma reflexão sobre os discursos, projetos e os sonhos de "jóvenes exponentes da la intelectualidad liberal" que "voluntariamente se reuníam a compartir informatión y debatir sobre el presente y el futuro de su país" (p. 10). O artigo é muito interessante por possibilitar comparações dos temas e ideias que circulavam entre os livres-pensadores em diversos países no mesmo período.

A questão dos debates políticos e culturais em Portugal no contexto da decretação da Lei de Separação de 1911 foi o tema do artigo "Para lá do anticlericalismo: a separação das Igrejas do Estado como embate cultural (no contexto da Lei de Separação de 1911)" do teólogo e historiador Sérgio Filipe Ribeiro Pinto. $\mathrm{O}$ autor faz uma excelente síntese da legislação republicana anterior à separação, onde destaca medidas laicizantes em várias áreas como no ensino, registros civis, leis de famílias, etc. A segunda parte do texto é dedicado ao exame pormenorizado da Lei de Separação (1911) que colocou termo a religião de Estado. Para Ribeiro Pinto "o ímpeto laicizador do republicanismo" tinha como propósito "conter a religião dominante, e com ela as demais denominações, para a consecução da revolução cultural (antropológica, política, social) considerada imprescindível para a revitalização de um país decadente" (p. 251). Também evidencia que o conflito entre mundividências antagônicas (republicana e católica) esteve na base e além do anticlericalismo. 
O historiador Tiago Pires Marques em "Religião e anticlericalismo no nascimento da psiquiatria moderna (Portugal e França, c. 1870-c. 1920)”, aborda, de forma inovadora, a temática do anticlericalismo na sua relação com a psicanálise. Nesse artigo analisa-se como muitos psiquiatras, franceses e portugueses, utilizaram a nova ciência da alma com instrumento na luta contra o clericalismo finissecular. "A argumentação 'científica', de cunho psiquiátrico, patologizando certas formas de vida religiosa foi (...) a face mais radical do anticlericalismo em Portugal” (p.297). Os jesuítas foram os alvos principais dos psiquiatras anticlericais, que viam nesse grupo religioso pessoas delirantes, loucas e degeneradas, passíveis de tratamento médico. $\mathrm{O}$ autor conclui que o problema da relação entre loucura e religião nesse contexto "foi um dos vectores de transformação do racionalismo positivista e da formação de uma nova paisagem cultural” (p.318).

$\mathrm{O}$ artigo que encerra a obra é um estudo de caso. O historiador Luciano Ramírez em "Anticlericalismo en uma ciudad conservadora de la província mexicana: 'Aguascalientes en la historia', el polémico mural del Palacio de Gobierno", analisa uma intensa controvérsia envolvendo a hierarquia da Igreja Católica - apoiada por parte de sociedade e da imprensa - e o governo laico de Aguascaliente no México em 1960. O conflito estava ligado à pintura de um mural no Palácio do Governo levado a cabo pelo artista chileno Oswaldo Barra Cunningham, discípulo de Diego Rivera. O mural foi interpretado, por parte de setores ligados a Igreja, como anticlerical. O governo foi acusado, pela imprensa local, de querer fomentar o velho anticlericalismo da década de 1920. A crise termina em 1962, quando um novo governador foi eleito e conseguiu abrandar a polémica, com o passar do tempo "la gente aprendió a valorarlo y respetarlo" (p. 372).

A obra pode ser considerada como uma contribuição significativa, pertinente e necessária para os estudos sobre o anticlericalismo "transatlântico". A qualidade dos artigos é indiscutível. No entanto, percebe-se que a realidade latino-americana poderia ter sido mais bem explorada, inserindo as experiências de outras nações que experimentaram o mesmo fenómeno, como Brasil e Argentina. Outro aspecto que merece consideração é a constatação de que os artigos analisam fundamentalmente o fenómeno do anticlericalismo preso aos limites do Estado nação. As influências europeias e/ou vice-versa são raramente mencionadas.

Ivo Pereira da Silva

Doutorando em História / Capes Universidade de Coimbra / CHSC Universidade Federal do Pará (BR) ivosilva@ufpa.br 


\section{Burke, Peter (2008) O que é História Cultural? Tradução Sér- gio Goes de Paula, $2^{\text {a }}$ edição revista e ampliada. Rio de Janeiro: Zahar, 177 pp., ISBN: 978-85-378-0869-6}

A obra assume uma perspectiva sobre a discussão teórica da História Cultural dos anos setenta do século XX na Europa e reflete, sobretudo, as diferenças e os conflitos culturais na produção do conhecimento histórico. A definição de cultura revela que qualquer explicação de História Cultural caminha para o campo interdisciplinar, local e global. Como bem sublinha Peter Burke, um dos aspectos que melhor caracteriza a prática da História Cultural nas décadas de sessenta a noventa do século XX é o caminho de aproximação da História à Antropologia, essencialmente por conta dos problemas da compreensão do termo cultura.

O primeiro capítulo - A grande tradição - remete para a tradição alemã. Recupera a noção de "espírito da época" e insiste na exploração das formas, linguagens e sentimentos de expressão cultural. Analisa os contributos dos sociológos Max Weber e Norbert Elias que, nos finais dos anos trinta, estudaram o processo civilizador. Aborda a noção de cultura na obra de Aby Warburg, que elegeu como campo de reflexão o Renascimento e de Ernst Gombrich que, nos anos sessenta, estudou a relação entre verdade e estereótipos.

A década de trinta, em função da ascensão de Hitler ao poder, foi marcada pela fuga de cientistas para Londres e Estados Unidos e por um recurso mais insistente no conceito de "civilização". A palavra-chave era "civilização", mais que "cultura" (p. 19).

A diáspora dos intelectuais alemães possibilitou o desenvolvimento de diferentes enfoques sobre cultura e sociedade. Na década de cinquenta, o marxista Arnold Hauser estudou a história social da arte. Na década de sessenta, a História Social fez a descoberta do povo e, na década seguinte, a "formação da classe operária inglesa" de Edward Thompson assinalou o lugar central doravante conquistado pela cultura popular. Na linha de valorização da História Social da Cultura merecem análise cuidadosa os contributos de Jacques le Goff e dos historiadores ligados à Escola dos Annales.

No segundo capítulo - Problemas da História Cultural -, Peter Burke reflete que os métodos, as fontes e as conclusões têm confiabilidade relativa, por serem produzidos e escolhidos com elevado condicionamento. "O problema levantado por Clapham acerca das leituras subjetivas dos textos é bem mais difícil de resolver" (p. 26). 
O terceiro capítulo - A vez da Antropologia Histórica - refere a aproximação da Antropologia com a História, ressaltando a importância dos valores culturais para explicar a produção e o consumo. Os historiadores J. Elliott e R. Chartier voltaram a sua atenção para o pensamento, as ideias e a produção escrita. $\mathrm{O}$ antropólogo Geertz ampliou o termo cultura e influenciou historiadores, como Robert Darnton. E nesta lista de historiadores da História Cultural do final do século XX incluem-se: Georges Duby, Le Roy Ladurie, Daniel Roche, Lynn Hunt e, entre outros, Carlo Ginzburg.

Na década de setenta do século $\mathrm{XX}$, cresceu a discussão entre macro-história e micro-história. A micro como reação às explicações das narrativas e generalizações dos processos da civilização ocidental e como reação à globalização em favor da cultura regional e local.

O capítulo 4 questiona a emergência de um novo paradigma de pesquisa. O novo modo de fazer História da Cultura é ponto de partida de uma outra teoria cultural. Esta teoria cultural tem reforço de importantes teóricos, tais como, Michel Foucault, Nobert Elias, Jürgen Habermas, Mikhail Bakhtin e Pierre Bourdieu. Observamos as variedades da Nova História Cultural de Mikhail Bakhtin com os conceitos de carnavalização e subversão da alta cultura pela baixa e a prevalência dada a muitas vozes, como se de um texto de polifonia se tratasse. É de Norbert Elias o conceito de processo civilizador. Apesar de criticado, tem sido aplicado em múltiplas pesquisas de historiadores. Por seu turno, Michel Foucault com os conceitos de contrários, progresso e evolução analisou as descontinuidades culturais, as rupturas e a ideia de invenção da cultura, de redes de ideias e pensamentos ao nível da microfísica do poder. "Se Elias enfatiza o autocontrole, Foucault chamava a atenção para o controle sobre o eu, especialmente o controle sobre os corpos exercidos pelas autoridades" (p. 58).

Por fim, saliente-se Pierre Bourdieu com a ideia de "reprodução cultural" teoria da prática, de habitus que distingue de regras, emprego de bens, produção e capital relacionado com a cultura e a teoria da estratégia de distinção cultural a afirmação da identidade social.

Novos paradigmas da Nova História Cultural dos quais se destacam: 1 - O estudo das práticas, a exemplo das práticas religiosas diferentes da teologia; da fala diferente da linguística; do experimento diferente da teoria e assim profissionalizaram-se vários temas, tais como, esportes, maneiras à mesa, consumo, fala, viagem, leitura etc.. 2 - Estudos das representações, construção do imaginário social, reflexo das estruturas sociais e criação das ideias. 3 - A História da memória e da ação e aceleração das transformações sociais que ameaçam a identidade, apesar de sabermos que as memórias são 
"contaminadas" pela cultura, por grupos diferentes, por momentos diferentes. 4 - O estudo da cultura material - os estudos dos objetos para compreensão de mudanças e relações sócio-culturais. 5 - O outro paradigma da Nova História Cultural é a história do corpo centrada na identificação dos elementos culturais da vida, nos aspectos físicos e na carga simbólica dos gestos, higiene, etc..

A revolução da História Cultural evoluiu a partir da Antropologia histórica, neste sentido, o autor refere os contributos de Jaques Le Goff, Natalie Zemon Davis, e Keith Thomas.

O quinto capítulo - Da Representação à Construção - desenvolve uma análise da mudança da História Cultural para a História Social da Cultura e para a produção da realidade criada, em que a linguagem não é mais o reflexo do objeto e as histórias apresentam versões quanto ao ponto de vista escolhido: vista de baixo, a visão dos colonizados, a visão dos derrotados, das classes subalternas, das mulheres etc.. É a criação da realidade e o declínio do determinismo.

Quanto às variáveis desse construtivismo podemos perceber a reutilização do pensamento de Michel de Certeau que analisou as práticas das pessoas comuns, a criatividade e a inventividade nas apropriações e no consumo das ideias e objetos.

A construção do conceito de género, masculino e feminino, e as distinções de masculinidade e feminilidade são modificadas historicamente. Refira-se ainda outro valor do construtivismo: a construção das comunidades, sob o signo do livro. "Comunidades Imaginadas" (Benedict Anderson) e "invenção da tradição" (Hobsbawm) em que se mesclam múltiplas tradições, antigas, recentes e (re)inventadas. Em relação à construção da monarquia, como em relação à construção da nacionalidade são usadas as festividades, coroações, casamentos, funerais, procissões religiosas e paradas militares para evidenciar a construção de um ideal de unidade (p.88).

Em relação à construção de identidades individuais, importa realçar que estas representam um eu forjado no coletivo, que está para além da biografia como construção de identidade para si mesma. É a chamada virada performativa e modelo dramatúrgico. Dizer a performance de consensos, das festividades, performance de nacionalismo, da história ou da memória, performance da linguagem, da metáfora que não só expressa, porém ajuda a criar a identidade, ainda a performance como o contrário de regras culturais, dos improvisos de recriação e de conflito dos significados. Igualmente a ascensão do ocasionalismo - ideia de distanciamento das regras fixas, respostas flexí- 
veis às lógicas sociais, a exemplo do tipo de linguagem ou gesto para cada tema, cargo ou ocasião.

$\mathrm{O}$ autor trabalha ainda com o conceito de desconstrução, categoria que em cada tempo os historiadores utilizam como projeção de valores sobre o do passado. Portanto, o construtivismo é antagónico, a visão simplista da identidade, ainda cria problemas cuja solução está longe de ter respostas para questões como: que restrições se constroem? A partir de quê? Ou melhor, há uma criação contínua da cultura a partir de elementos velhos e novos?

O sexto capítulo - Além da virada cultural? - Assinala o retorno a Burckhardt e sustenta que a história cultural tradicional persiste nos estudos da alta cultura, coexistindo com o interesse despertado pela cultura popular. Os deslocamentos e ênfases da Nova História Cultural acontecem a exemplo de O queijo e os vermes de Carlo Ginzburg.

Outras extensões da Nova História Cultural são os estudos da História Cultural da política, da violência e das emoções. A cultura e a política estão presentes em muitas produções sobre os simbolismos das monarquias e repúblicas. É a chamada cultura política de Lynn Hunt que trata da Revolução Francesa e seus comportamentos políticos, além de Thompson, Levi Strauss, Foucault e Derrida que também se dedicaram ao tema. Temos, também, Shahid Amim sobre a imagem de Gandi na consciência camponesa. $\mathrm{O}$ movimento de formação dos grupos de estudos dos subalternos na Índia, na Irlanda e na América Latina servem de exemplo da expansão da Nova História Cultural.

A reflexão de uma vingança da História Social como reação à expansão da Nova História Cultural sugere que esta foi muito longe e que existe um problema de subjetividade, de definição, de método e fragmentação, para além dos limites próprios do construtivismo. Percebe-se a existência de problemas na relação entre cultura e sociedade e não se pode perder de vista as estruturas políticas e económicas. Como a Nova História, a Nova História Cultural evoluiu. Novos objetos, novos problemas, novas abordagens, novas fontes, novos métodos são objecto de intenso debate.

Quanto ao tópico "as fronteiras e o encontros" existe uma tentativa de romper com a fragmentação, com o conceito de fronteira cultural e a questão é de onde se olha cada área cultural, ou seja, como fazer as distinções, como tratar os grupos fluidos entre estas fronteiras e as zonas de contacto e convivência de opostos numa cultura híbrida.

A narrativa na História Cultural foi anteriomente ligada à visão tradicional, a narrativa volta para dar voz às pessoas comuns, histórias de vida, narrativas culturais suas estruturas e versões, na perspectiva do leitor. O desafio 
é fazer isso sem dar à História um enredo triunfalista e enfatizar a crítica e o conflito de visões e de sentido de cada narrativa.

Peter Burke observa que a Nova História Cultural pode chegar ao fim, todavia o seu percurso ainda está em crescimento, ou melhor, em processo. As questões persistem sem soluções e novas surgirão. Os historiadores culturais e sociais ampliam os seus territórios. Não existe defesa de que a História Cultural é a melhor forma de História, porém as suas contribuições são pertinentes e necessárias. E quaisquer que sejam os resultados não será possível retornar à compreensão positivista dos documentos históricos, uma compreensão literal onde não se destacam os simbolismos.

Concluímos que a História Cultural não é monopólio dos historiadores. É multidisciplinar, por esta razão torna-se difícil a sua definição. As invasões de fronteira e território são comuns entre a história literária, a arte e a antropologia, tomando emprestados os seus conceitos. Mas também com a sociologia, o folclore, a geografia, a arqueologia, a ecologia, entre outros. Para além disso, a História Cultural aproxima-se dos conceitos de performance social, construção cultural, tradição, herança, construção cultural dos espaços, antropologia cultural e arqueologia. Como projeção, até a ecologia se aproxima da História Cultural. O movimento dos estudos culturais, enfrentando embora a ameaça de ser engolido por outros contributos gerados a partir dele, cruza-se ainda com a história da memória e do quotidiano.

Enfim, algumas das questões levantadas nasceram do embate, da guerra, da cultura e da rejeição - a cultura dos homens brancos mortos, em contraponto com afro-americanos e do estudo das mulheres na história. E desta forma seguem o embate sobre o multiculturalismo, termo que pressupõe a existência de diversas culturas em um mesmo espaço, estimuladas a conservar as suas identidades. As questões levantadas suscitam a pergunta: onde estão as fronteiras culturais e o que é autencidade cultural? Os historiadores culturais não resolverão os problemas, porém têm a possibilidade refletir sobre tais questões. 
Notícias 



\section{Centro de História da Sociedade e da Cultura - 2014 \\ Breve descrição das actividades desenvolvidas}

No decurso de 2014 o CHSC deu continuidade à investigação desenvolvida no âmbito dos Grupos "Sociedades, Poderes e Culturas: Portugal e os Outros" (SoPoC) e "História da Região Centro de Portugal” (HRC). No caso do primeiro, investiu-se no reforço da internacionalização, concretizada através da participação em redes de investigação e em parcerias com centros e associações sediados na Europa e na América, tendo como principais eixos temáticos questões interdisciplinares, entre as quais as problemáticas da fronteira, da propriedade fundiária e das práticas alimentares e educativas. Acentuou-se também a ligação do CHSC a outras unidades de investigação portuguesas, materializada na edição de obras conjuntas, na organização de seminários ou na participação em projectos conjuntos.

Verificou-se também um aumento do número de artigos em revistas internacionais de referência, resultantes ou não da participação em encontros científicos realizados no estrangeiro, em alguns dos quais os investigadores do CHSC colaboraram nas respectivas comissões organizadoras e/ou científicas, ou em actividades de coordenação.

O conjunto da produção historiográfica desenvolvida por ambos os grupos de investigação, concretizada já no projecto Pest-OE/HIS/ UI0311/2014, abrangeu, no caso do SoPoC, áreas muito diversificadas, das quais se devem salientar Instituições e redes de poder, História do pensamento e representações políticas e culturais, Historiografia, História religiosa e eclesiástica, História do género ou História da vida privada. Quanto às relações de Portugal com o exterior, a história da expansão e da colonização portuguesas continuou a marcar a actividade científica do CHSC, em estudos que se debruçaram sobre os estabelecimentos criados a partir da conquista de Ceuta em 1415, quer nas ilhas e costa africana, quer no Oriente, quer no continente americano. Entre os estudos que se centram nesta temática, destacam-se alguns dedicados a diferentes aspectos do fenómeno da aculturação, da alimentação à religião e à educação propriamente dita, no sentido em que poderão marcar novas perspectivas de abordagem a prosseguir no futuro.

Indicadores de Execução

\begin{tabular}{l|c}
\hline Publicações & \\
\hline Livros & 12 \\
\hline
\end{tabular}




\begin{tabular}{l|c}
\hline Artigos em revistas internacionais & 20 \\
\hline Artigos em revistas nacionais & 16 \\
\hline Comunicações & \\
\hline Comunicações em encontros científicos internacionais & 93 \\
\hline Comunicações em encontros científicos nacionais & 97 \\
\hline Relatórios & 4 \\
\hline Organização de seminários e conferências & 47 \\
\hline Formação avançada & \\
\hline Teses de Doutoramento & 6 \\
\hline Teses de Mestrado & 22 \\
\hline Capítulos de Livros / Books Chapters & 44 \\
\hline Coordenação editorial/Editorial Coordination & 9 \\
\hline Entradas de Dicionários e Enciclopédias & 13 \\
\hline
\end{tabular}

Pelo seu lado, o grupo de investigação HRC reflecte o interesse pela história local, interesse ao qual não deve ser completamente alheia a formação e o trabalho produzidos em mestrados e doutoramentos. Para além dos estudos elencados em lugar próprio, deve registar-se um conjunto de actividades relacionadas com a celebração dos 500 anos dos forais manuelinos, entre as quais, a participação no Colóquio No tempo dos forais manuelinos, bem como conferências, comunicações, capítulos de livros ou mesmo da edição, análise e enquadramento histórico de diferentes cartas de foral. Investiu-se também na investigação de outros vestígios materiais e imateriais, concretizada em estudos e iniciativas que contribuíram para a difusão e conhecimento de tradições ou aspectos da cultura das comunidades locais.

No capítulo das fontes mantêm-se activos os projectos de edição das Notícias e Memórias Paroquiais Setecentistas - um projecto colectivo assumido por vários investigadores do grupo HRC e que deu já a conhecer, a partir de inquéritos realizados no século XVIII, o património de mais de 10 concelhos da Região Centro - e da edição da Chancelaria de D. Dinis. Outros trabalhos integram-se no estudo da Diplomática, da Sigilografia e da Codicologia, salientando-se, também, a vertente prática do estudo da Paleografia, concretizada em Workshops. 


\section{No XI Centenário da Doação de Santa Maria de Formoselha à Sé de Coimbra: Evocação histórica.}

Formoselha é um bucólico e encantador lugar, como o próprio topónimo manifesta (formosellus é o diminutivo de formoso), situado na margem esquerda do Mondego, que actualmente pertence à freguesia de Santo Varão (c. Montemor o Velho) e dista de Coimbra 18,3 Km. A sua história, como comunidade cristã organizada, remonta vários séculos atrás. Acha-se patente num documento de 1 de outubro de 915 . Neste diploma, Formoselha e a sua igreja de Santa Maria são doadas por Lúcido Vimaranis e esposa, D. Gudilo, ao bispo de Coimbra, D. Gomado. O documento em apreço não é o original (que certamente se perdeu), mas uma cópia fidedigna lançada, nos finais do século XII, no grande Tombo de propriedades (e outros registos) da Sé de Coimbra conhecido por Livro Preto onde tem o número 169.

1. Após a conquista muçulmana da Península Ibérica o baixo vale do Mondego (como várias outras regiões) estabelecera um pacto com os invasores: a população cristã manter-se-ia na posse das suas propriedades, que continuaria a cultivar, mediante o pagamento de um imposto especial entregue regularmente aos muçulmanos. Além disso, ficava aquela mesma população autorizada (mediante pagamento) a praticar o seu culto religioso de acordo com determinadas regras. Com o fim de esbater as diferenças culturais e as de credo (geradoras de discriminação), os cristãos buscaram uma aproximação com o modo de vida muçulmana: passaram a vestir-se como os invasores, aprenderam a sua língua e utilizaram normalmente dois nomes - um, muçulmano para ser usado no exterior; outro, cristão pelo qual eram nomeados em casa - Galib Alkarrac, cognomento Jhoannes Petriz; ou ainda um nome simultaneamente cristão e muçulmano - Martinus Ibn Atumati. Estes cristãos arabizados, que ficaram conhecidos por moçárabes, serão grandes protagonistas políticos e religiosos em Coimbra e sua região entre os séculos IX-XII.

Em 878 o conde Hermenegildo Guterres reconquistou Coimbra. Porém, devido à sua localização, a cidade e seus arredores, embora cristãos, eram ainda assaz perigosos, visto tratar-se de uma zona de fronteira muito exposta aos ataques inimigos. Apesar disso, este limite sul da Galecia era também terra de oportunidades: de enriquecimento e prestígio alcançados nos combates com os mouros; e de refúgio, em 
particular para os magnates, que vindos do norte cristão agitado por revoltas graves e frequentes, buscavam na stremadura, isto é na fronteira, pôr-se a salvo dos seus perseguidores.

2. O baixo vale do Mondego, onde se situa Formoselha, é um dom da natureza: a abundância de água e a fertilidade do solo permitiram a fixação de população numerosa. O testemunho mais eloquente destas características é-nos dado pelos próprios muçulmanos. Os seus geógrafos louvam, com admiração, este paraíso onde há de tudo - vinha, cereais, árvores de fruto, peixe, inúmeros cursos de água, que faziam mover muitas azenhas, caça abundante acoitada nas brenhas e matas frondosas... E - facto assombroso para os mesmos geógrafos - os habitantes do referido vale, que eram trabalhadores laboriosíssimos, criavam toda a espécie de animais bem nutridos, não só volatilia e pequenos ruminantes, mas principalmente vacas e cavalos. Esta última informação é da maior relevância: por um lado, a mencionada criação de animais (em particular o gado grosso), possibilita aos seus detentores uma valiosíssima riqueza móvel que pode ser deslocada em caso de perigo; por outro, determina a importância social e política que os moçárabes detiveram em Coimbra até ao século XII: possuir um cavalo e apresentar-se na guerra montado, condicionou, de modo positivo, a sua influência. Esta última situação acha-se perfeitamente manifesta no foral concedido a Coimbra pelo conde D. Henrique a 26 de maio de 1111. Ali, e após uma tentativa frustrada do conde para impor na cidade modelos políticos trazidos de fora, os moçárabes cientes da sua importância, revoltaram-se forçando D. Henrique a aceitar as suas reivindicações.

3. O valor de Formoselha patenteia-se no diploma de 1 de outubro de 915 sob duas vertentes, que mutuamente se complementam: É um lugar cristão povoado, ou seja, com vida organizada, como manifesta a existência de uma igreja dedicada à Virgem Santa Maria, Mãe de Deus; o dito lugar é detido por magnates da mais alta categoria social - os condes Lúcido e sua esposa D. Gudilo. Além disso, alguns dos subscritores (identificáveis) do mencionado documento são, na sua maioria, parentes próximos dos outorgantes, o que indicia a origem familiar dos bens. Das vinte e quatro testemunhas que naquele subscrevem apenas oito, podem ser identificadas, visto que o nome próprio vem seguido do patronímico que parece não ser de gente comum. Além do casal doador, que também confirma o diploma, subscrevem o mesmo 
quatro membros da sua família: o filho, Alvito Lucides; o genro, Diogo Fernandes; o neto, Múnio Alvites, filho do primeiro; e o genro de Alvito Lucides, Tedon Afonso.

Apesar dos onze séculos que nos separam da data da redação deste documento, sabemos hoje, com relativa segurança, quem são os seus outorgantes. Trata-se de um casal pertencente à mais alta estirpe: Lúcido é filho do conde presor de Portucale - Vímara Peres; Gudilo é provavelmente filha do primeiro reconquistador de Coimbra (878) - Hermenegildo Guterres e de sua esposa Ermesinda Gatões, prima coirmã do rei Afonso III das Astúrias (866-910). A valiosa doação, que naquela data, os mencionados proprietários fazem à Sé de Coimbra, provém-lhes certamente, da herança paterna de D. Gudilo. $\mathrm{Na}$ verdade, a fórmula tabeliónica utilizada no diploma em apreço, é pouco habitual naquela época e deixa antever a origem feminina das propriedades: "Lucidus una cum consensu uxoris mee (... )" isto é, "Lúcido, com a anuência de minha esposa...”. O notário, como atualmente acontece, localiza os bens em causa, afirmando que a igreja de Santa Maria e outras propriedades ficam situadas "in villa que dicent Fremoselio juxta flumen Mondeci territorio Colimbriense". Além disso, o referido documento informa ainda, que os respetivos limites das propriedades se fixam "per suos antiquiores terminos", podendo isto significar que antes de 915 (ou ainda antes de 878) os ditos bens haviam pertencido à família da estirpe conquistadora, talvez os pais de Hermenegildo (Guterre e Elvira), ou, com mais probabilidade, aos pais desta - Gatão e Égilo (recorde-se, em abono desta última hipótese o topónimo Gatões no atual concelho de Montemor).

Novas e violentas investidas muçulmanas atingiram nos fins do século $\mathrm{X}$ a Península Ibérica, em particular aquelas comandadas por Almançor. Coimbra é novamente tomada e destruída pelos invasores (987). A igreja de Santa Maria de Formoselha desapareceu, sobrevivendo desta época entre nós, apenas um templo - S. Pedro de Lourosa (c. Oliveira do Hospital), sagrado em 912.

Quando a cidade do Mondego é reconquistada definitivamente pelos cristãos em 9 de julho de 1064 surgirão novos senhores e as terras repartir-se-ão e organizar-se-ão de outro modo. Mas aqui, no Campo do Mondego onde os moçárabes lutaram heroicamente, mas também conviveram com os invasores durante vários séculos, operou-se a fusão de duas culturas, dando 
origem a uma nova língua que ganhou reconhecida autonomia quando a 27 de junho de 1214 se elaborou, em Coimbra, o primeiro grande documento oficial totalmente redigido em português - o testamento do rei D. Afonso II.

Maria Teresa Nobre Veloso

Universidade de Coimbra / CHSC mtnveloso@fl.uc.pt

\section{"A Institucionalização da Ciência Moderna em Portugal: Univer- sidade, Obras Públicas e Museus", Ciclo de Conferências, Facul- dade de Letras da Universidade de Coimbra/Centro de História da Sociedade e da Cultura, 17 de abril - 20 de maio de 2015.}

No âmbito do Seminário Pensamento e Práticas Culturais II e por iniciativa da professora regente deste curso de Doutoramento em Altos Estudos em História, realizou-se na Faculdade de Letras da Universidade de Coimbra, entre os dias 17 de abril e 20 de maio de 2015, um Ciclo de Conferências subordinado ao tema: "A Institucionalização da Ciência Moderna em Portugal: Universidade, Obras Públicas e Museus. A iniciativa, destinada a jovens investigadores e estudantes de doutoramento, contou com o apoio do Centro de História da Sociedade e da Cultura.

Realizadas com uma periodicidade semanal, as conferências foram proferidas por reconhecidos especialistas e motivaram vivos debates dos participantes, professores e estudantes dos cursos de graduação e pós-graduação da Faculdade de Letras e da Faculdade de Ciências e Tecnologia. A concretização do programa contou a generosa colaboração dos seguintes conferencistas: Fernando Taveira da Fonseca, Professor da Faculdade de Letras da Universidade de Coimbra e investigador integrado do CHSC, que proferiu a conferência: "Uma Primeira Educação do Olhar: estudantes de Coimbra na transição reformista”, a 17 de abril; Fernando José Bandeira Figueiredo, bolseiro de pós doutoramento da FCT e investigador integrado do CITEUC, que dissertou sobre "A Institucionalização do Conhecimento Científico na Universidade de Coimbra: o contributo de José Monteiro da Rocha para a reforma de 1772", a 24 de abril; Carlos Henrique Martins, Professor do Departamento de Arquitetura da Faculdade de Ciências e Tecnologia da Universidade de Coimbra que demonstrou como se processou a "Aplicação da Ciência à Política do Território, na transição do século XVIII para o século 
XIX”, em conferência proferida a 8 de maio; e João Carlos Brigola, Professor do Departamento de História da Universidade de Évora e investigador integrado do CIDEHUS, que encerrou este ciclo, a 20 de maio, com a conferência: "O Gabinete de História Natural da Ajuda: um projeto de recuperação cultural, patrimonial e museológico (1768-2018)”.

O carácter interdisciplinar das reflexões produzidas e a discussão em torno de investigações recentes e em curso sobre matérias relacionadas com os temas analisados marcaram de forma muito positiva todos quantos colaboraram e participaram neste encontro de especialistas e estudiosos.

Ana Cristina Araújo

Universidade de Coimbra / CHSC araujo.anacris@sapo.pt

\section{Encontro Luso-Brasileiro - Portugal e Brasil: Diálogos historio- gráficos, Faculdade de Letras da Universidade de Coimbra, 4 a 5 de maio de 2015}

A implementação de uma política consistente no domínio da investigação, tendo em vista a execução de projetos, de ações de mobilidade de estudantes e de docentes e o desenvolvimento e cooperação científica, é uma aspiração das Universidades e dos Centros de Investigação. Por isso, não podem hoje os Programas de Doutoramento deixar de se integrar num quadro de estreita colaboração com as Unidades de Investigação, proporcionando assim uma avançada formação teórica e uma ampla difusão do conhecimento por via de um trabalho em rede, do estabelecimento de projetos conjuntos de pesquisa, de parcerias institucionais e da realização de seminários e workshops conjuntos. Por outro lado, as participações e apresentações de comunicações em reuniões científicas públicas, a organização de seminários e outras iniciativas associadas aos interesses de pesquisa dos doutorandos fazem parte da sua formação e avaliação.

Enquadrado por estes pressupostos, o $3^{\circ}$ Ciclo em Altos Estudos em História, em parceria com o Centro de História da Sociedade e da Cultura (CHSC), realizou, nos dias 4 e 5 de Maio de 2015, um Encontro Luso-Brasileiro (constituído por um Colóquio e um Seminário), destinado sobretudo a 
Doutorandos e Pós-Doutorados, subordinado ao tema Portugal e Brasil: Diálogos historiográficos. Tendo em conta o número significativo de estudantes brasileiros que frequentam o referido Curso de Doutoramento, teve-se como objectivo promover o diálogo historiográfico, em contexto interdisciplinar, nos territórios luso e brasileiro, entre estudantes, investigadores e professores (nacionais e brasileiros), com vista à divulgação e à valorização de projetos de investigação em curso.

Pretendeu-se, assim, abrir um espaço de reflexão crítica que possibilitasse o debate sobre a importância que têm as relações entre os dois países no âmbito da produção de conhecimento, nomeadamente no campo da investigação em História. Procurou-se proporcionar uma discussão, interpelativa e problematizadora, em torno dos trabalhos desenvolvidos e/ou a desenvolver por doutorandos e pós-doutorados: das experiências que se vão construindo nos dois espaços do Atlântico por diferentes pessoas que estiveram e estão em crescente mobilidade, tanto nas dimensões transnacionais e transculturais, como nos modos como nos relacionámos e relacionamos, no tempo e no espaço, nos domínios da interculturalidade.

No âmbito desta ligação ao Brasil, também o CHSC conta com um passado de forte colaboração e de intercâmbio de investigadores, patente na mobilidade de professores, bem como numa longa série de iniciativas conjuntas e de projetos de investigação luso-brasileiros. Por outro lado, vários são os membros desta Unidade de Investigação integrados em projectos ou redes luso-brasileiras e relevante é a colaboração que se tem desenvolvido com universidades e institutos de pesquisa do Brasil, o que se tem traduzido num incremento da mobilidade de docentes e da cooperação institucional.

Em concreto, estiveram presentes neste Encontro, que se revelaria de profícuo intercâmbio científico, os Doutores Rosângela Patriota Ramos, Alcides Freire Ramos e Rodrigo de Freitas Costa, da Universidade Federal de Uberlândia.

Foram também convidados a intervir orientadores e orientandos, investigadores do CHSC e estudantes do Curso de Doutoramento em Altos Estudos em História que estão a trabalhar sobre relações/influências entre Portugal e o Brasil. Propôs-se-lhes que apresentassem os resultados das pesquisas em curso, partilhassem as suas atividades de investigação, a fim de que esses trabalhos pudessem ser debatidos, promovendo-se o diálogo científico. Solicitaram-se-lhes reflexões sobre a História dos dois países e uma troca de experiências: de perspectivas teóricas diversas, de métodos de pesquisa distintos, em busca, em última análise, de um estímulo para a construção do conhecimento científico, em cooperação. 
Responderam professores portugueses (da UC) e brasileiros (de S. Paulo e da Universidade Federal de Uberlândia); doutorandos e doutorados, alguns portugueses e muitos brasileiros, provenientes de diferentes universidades do Brasil (de Brasília, do Ceará, da Universidade Federal de Goiás, da Universidade Federal do Pará, da Universidade Federal de Pernambuco, da Pontifícia Universidade Católica de Minas Gerais e da Universidade Federal do Piauí) - muitos destes, simultaneamente, Professores, assistentes ou contratados, em instituições de ensino superior brasileiras.

Os arquivos, a Paleografia e as fontes (escritas e iconográficas, medievais e modernas, ao serviço do poder laico ou do poder eclesiástico); a produção historiográfica brasileira sobre o medievo português; a história do Brasil (dos séculos XVI a XVIII) sob o olhar de um historiador português; as linguagens artísticas e os diálogos significativos para a história cultural; o Sebastianismo no Brasil; o anticlericalismo no Parlamento brasileiro; a história da mineralogia numa perspectiva transversal a Portugal e ao Brasil; a questão urbana e a importância da imigração lusitana para a construção do Brasil Contemporâneo são alguns dos muitos temas (num total de 17 comunicações) que, ao longo do dia 4 de Maio, foram objeto de intenso e proficiente debate.

No segundo dia (5 de Maio) realizou-se o Seminário/Workshop Fazer História. Aberto pelo Doutor Fernando Catroga, com a reflexão Descentrações culturais na investigação histórica em países estrangeiros, centrada na problemática da orientação de teses de doutoramento (por portugueses ou por brasileiros) cujos objetos de estudo se situam do lado oposto do Atlântico, foi depois preenchido com a apresentação pelos Doutorandos do $3^{\circ}$ Ciclo em Altos Estudos em História dos projetos de investigação em curso - todos eles cuidadosamente apreciados por parte dos presentes.

A pronta adesão de todos provou o interesse demonstrado por esta iniciativa e reforçou a necessidade de se continuar neste caminho.

LEONTINA VENTURA

Universidade de Coimbra / CHSC leventura@sapo.pt
IRENE MARIA VAQUiNHAS

Universidade de Coimbra / CHSC irenemcv@fl.uc.pt 


\section{Encontro de Jovens Investigadores em História Moderna. Universidade do Porto, 4 a 6 de junho de 2015}

Realizou-se na Faculdade de Letras da Universidade do Porto, entre os dias 4 e 6 de junho de 2015, o IV Encontro de Jovens Investigadores em História Moderna. Este encontro internacional, de carácter bianual, deu continuidade aos que decorreram no ISCTE - Instituto Universitário de Lisboa (2009), na Universidade do Minho (2011) e na Universidade de Évora (2013). A sua próxima edição, em 2017, conta com o acolhimento da Faculdade de Letras da Universidade de Coimbra e com o apoio do Centro de História da Sociedade e da Cultura (CHSC).

Destinados a estudantes pós-graduados, cuja formação se firme no campo da História Moderna, estes encontros têm proporcionado aos Jovens Investigadores ocasiões de partilha de conhecimentos, experiências e metodologias de trabalho e de debate acerca de temáticas inseridas no vasto âmbito da História. As investigações em curso e os problemas que marcam o desenrolar dos projetos de pesquisa contribuem para o alargamento das perspetivas historiográficas dos participantes. Por meio desta interação, torna-se mais estimulante a comunicação e o aprofundamento de novos campos e caminhos de investigação.

Ao longo dos três dias apresentaram-se 18 painéis que integraram um todo de 58 comunicações por investigadores em fase de pós-graduação, não doutorados. Cada orador dispôs de 15 minutos para dar a conhecer o estudo por si realizado e ao moderador de cada sessão coube comentar cada apresentação e ainda propiciar um momento de debate entre os presentes.

Os temas em análise foram: Ciência, Natureza e Cultura; Redes Económicas; Cultura(s) e material(ais); Escravatura: Comércio, Sociabilidade e Devoção; Brasil Colonial: representações e poderes (2 painéis); Arte e Património; Sociedade e Família: Género, Religião e Património; Misericórdias e Assistência; Diplomacia e Poder; Coroa e Corte na Monarquia Hispânica; Práticas Administrativas; Espiritualidade, Teologia e Cronística; Poder, instituições e assistência na Igreja Diocesana. A abertura do encontro ficou marcada pela conferência inaugural sobre "As famílias, as comunidades e as normativas religiosas na Época Moderna” proferida pela Doutora Helena Osswald. No dia seguinte, houve oportunidade de assistir a uma mesa-redonda que versou sobre projetos de investigação em História Moderna. Na noite do dia 5 , teve lugar um jantar que reuniu os participantes num ambiente 
familiar. $\mathrm{O}$ evento terminou com uma visita guiada à cidade do Porto, na tarde de sábado, último dia do encontro, dirigida por Joel Cleto.

Os participantes da edição de 2015 eram oriundos de Portugal (31), Brasil (18) e Espanha (9). A Universidade de Coimbra fez-se presente por meio de 5 jovens investigadores que levaram temas relacionados com a presença portuguesa no Brasil e na Ásia, Inquisição, Cultura das Luzes e Alimentação.

$\mathrm{O}$ evento foi promovido por uma equipa de jovens investigadores da Faculdade de Letras da Universidade de Porto, integrados em dois centros de investigação desta instituição, o CITCEM (Centro de Investigação Transdisciplinar «Cultura, Espaço e Memória») e o CEAUP (Centro de Estudos Africanos da Universidade do Porto). À equipa organizadora correspondeu uma comissão científica de investigadores mais experientes de diversas instituições do país.

Pensamos que que é de louvar a iniciativa de congregar a comunidade científica em torno de projetos de Jovens Investigadores pertencentes a diversas Universidades e Centros de Investigação. $\mathrm{O}$ ambiente propício ao debate e ao comentário de especialistas e, sobretudo, a possibilidade de contatar com colegas nacionais e estrangeiros, que trabalham em áreas de investigação próximas, comporta benefícios que extrapolam sobejamente o contexto do encontro. Note-se que, apesar de ser um Encontro de Jovens Investigadores, alguns historiadores portugueses já de renome e outros que agora constroem a sua carreira foram marcando presença tanto por espontânea participação como na qualidade de moderadores e conferencistas. Este diálogo entre diversas gerações de investigadores constituiu um motivo de regozijo para os participantes.

Espera-se que este tipo de eventos possa fazer-se cada vez mais em diferentes áreas de estudo, criando novos momentos de diálogo, aprendizagem, reflexão e aperfeiçoamento pessoal. O próximo encontro será, pois, em Coimbra, no ano de 2017, adivinhando-se um futuro promissor para esta iniciativa que merece, de toda a comunidade, uma peculiar atenção. 


\section{Alcalá 2015: Lupas Internacionais e Perguntas Inquisitoriais a Debate, "Nuevas Fronteras, III Simposio Internacional de Estudios Inquisitoriales". Faculdad de Derecho-Universidad de Alcalá, 10-12 de junio de 2015}

Organizado conjuntamente por distintas instituições académicas e ministeriais extra-europeias e nacionais, decorreu na Faculdade de Direito da Universidade de Alcalá de Henares (Espanha) o III Simpósio Internacional de Estudios Inquisitoriales, Nuevas Fronteras, nos dias 10-13 de Junho de 2015. Depois dos encontros de 2011 e de 2013, eis outro momento de debate e de troca de experiências de pesquisa sobre uma instituição chave do Antigo Regime, que marcou de maneira profunda a(s) História(s) das Penínsulas Ibérica e Italiana, de outros Países da Europa, assim como dos impérios de Ultramar, alcançando vários espaços da América, tanto portuguesa como espanhola, da África e da Ásia.

Para preparar o novo evento científico, foram necessários muitos meses até anos - de trabalho por parte do comité científico e organizador, no qual se pôde contar com a experiência e o espírito de iniciativa de especialistas ligados a centros universitários e académicos, brasileiros, italianos, espanhóis, mexicanos, ingleses, portugueses, franceses, chilenos, etc. (Anita Novinsky, U. São Paulo; Anna Foa, U. Roma La Sapienza; Carmen Sanz Ayán, U. Complutense Madrid; Fernanda Olival, U. Évora; Francisco Bethencourt, King's College de London; Gabriel Torres Puga, Colegio de México; Geraldo Pieroni, U. Tuiuti do Paraná; Giuseppe Marcocci, U. Tuscia; Ignacio Panizo Santos, AHNM; Irene Fosi, U. Chieti-Pescara; Jean Pierre Dedieu, CNRS,Toulouse-Lyon; José Pedro Paiva, U. Coimbra; Lina Gorenstein, Museu da Tolerância, U. São Paulo; Manuel Peña, U. Cordoba; Raphaël Carrasco, U. Paul-Valéry, Montpellier 3; René Millar Carvacho, Pontificia U. Católica de Chile; Ruth Fine, Hebrew University of Jerusalem).

Os dias do evento foram abertos pelas três conferências Inquisición y confesionalización. La Inquisición española en su contexto internacional; El Santo Oficio: nuevos interrogantes, nuevas respuestas; La Inquisición y la escritura de los conversos, proferidas respectivamente pelos professores Jean-Pierre Dedieu (CNRS Toulouse-Lyon), Doris Moreno (U. Autónoma de Barcelona) e Ruth Fine (Hebrew University of Jerusalem). Especialistas que começaram a trabalhar sobre o assunto inquisitorial abrindo novos caminhos sobretudo nas ultimas décadas do século passado, e que em Alcalá inauguraram os três 
dias, articulados em 9 simpósios temáticos e 11 mesas redondas, num total de 106 comunicações e 44 propostas de discussão. Um programa denso, que foi acrescentado com o lançamento de novos livros editados na Europa e no Novo Mundo, e ainda com a apresentação de um documentário divulgativo e respectivo DVD sobre o tribunal inquisitorial de Llerena.

O comité científico e a comissão organizadora (Juan Ignacio Pulido Serrano, U. Alcalá, Marco António Nunes da Silva, U. Federal do Reôncavo da Bahia, Susana Bastos Mateus, Cátedra Estudos Sefarditas, U. Lisboa, U. Evora; Edilece Souza Couto, U. Federal da Bahia, Francçois Soyer, U. Southampton; Isabella Iannuzzi, U. Roma La Sapienza; Miguel Rodrigues Lourenço, CEHR, U. Católica Portuguesa, CHAM U.Nova Lisboa; Suzana Maria de Sousa Santos Severs, U. Estado da Bahia) pretenderam favorecer o encontro dialógico entre historiografias de nacionalidades distintas, conforme evidenciava a capa do programa e das suas cinco traduções do lema do III Simpósio: New frontiers, Nouvelles Frontiéres, Nuevas Fronteras, Novas Fronteiras, Nuove Frontiere. Ao mesmo tempo - conforme sugeria possivelmente a capa com a planta da Inquisição de Goa - decidiu abordar novos espaços territoriais quer europeus quer de além mar, seja periféricos seja centrais; para penetrar, finalmente, ambientes quase desconhecidos até hoje, manejando fontes documentais pouco trabalhadas, dispersas ou trilhadas com novas perguntas. Realmente eram muitos os universos que gravitavam em torno da(s) Inquisição(ões): uma instituição multifacetada, e que funcionou ao mesmo tempo como tribunal, como centro de poder e de promoção social, como sinal de distinção ou de infâmia seja pelos juízes, seja pelas suas vítimas. Os tribunais da fé e da ortodoxia eram controlados por homens, por grupos selectos, centrados sobretudo nos espaços urbanos. Contudo, a sua extensão foi capilar, ramificada, projectando os seus olhares sobre uma heterogeneidade de homens e mulheres; sobre pessoas ou objectos, como livros e imagens; entre cidades e espaços diocesanos controlados por distintas autoridades civis e/ou eclesiásticas.

Nesse quadro pode-se inserir a Mesa 2, Inquisição e Episcopado: novas perspectivas, coordenada por Daniel Norte Giebels e Matilde Santos, jovens mas experientes investigadores do CHSC, Faculdade de Letras da U. Coimbra e do CHAM, U. Nova de Lisboa. Ambos, além de apresentar próprias comunicações (Vicissitudes da relação entre Inquisição e o episcopado: o caso de D. Miguel de Castro (?-1625; Inquisição e poder episcopal em Cabo Verde (XVI$-X V I I)$ ), moderaram também o participado debate, a seguir à apresentação das pesquisas de outros colegas como Josival Nascimento, CHSC, (A relação ente D. João de Melo, bispo de Coimbra (1684-1704)), e Ana Ruas Alves, 
CEHR, (O Episcopado e a Inquisição: dois poderes em sintonia ou em confronto? D. frei Inácio de Santa Teresa, um bispo jacobeu entre 1721 e 1751). O grupo conimbricense pretendeu nortear objectivos claros e aliciantes. Com efeito, além de apresentar áreas lusas distintas, alcançando uma visão global do conjunto de poderosas instituições que se debatiam a hegemonia jurisdicional ou de imagem no campo religioso, mostraram diversos eclesiásticos - seja do clero regular, seja secular - com formações em cânones ou teologia; residentes ou ausentes dos espaços de jurisdição quer portugueses quer do seu império. Bispos/inquisidores que tiveram uma circularidade de carreiras em diferentes dioceses, ou que acumularam no cursus honorum cargos diferentes como aconteceu em alguns proeminentes exemplos da metrópole; e que foram também membros de instituições à mercê da distância como era o caso das do arquipélago atlântico, onde a Inquisição portuguesa não dispunha de uma rede de comissários e familiares, pelo menos até meados do século XVII. Com outros objectivos analíticos alguns dos elementos do grupo conimbricense participaram também ao ST4 Inquisición e Iglesia, coordenado pelo professor Antonio Irigoyen López, U. Murcia. O fio condutor nesse caso foi também a relação de colaboração, concorrência ou conflito que a(s) Inquisição(ões) teve/tiveram com as múltiplas instituições que formavam o corpo eclesiástico. Destacou-se o desafio de encontrar ligações comparadas entre territórios muito mais variados, como Cabo Verde, Perú, Portugal, Brasil, Roma, Goa, Inglaterra e os territórios italianos. Os títulos dessas propostas, indiciam os variados temas do debate que, a partir de casos macro, passou a focar-se em exemplificações mais circunscritas: Taxonomias dominicanas italo-ibéricas: entre exaltação de dignidade(s) e proposta de um arquétipo (Paola Nestola, CHSC, U. Coimbra); The "heresies" of Giovanni Battista de Luca and Archival Sources of Roman Inquisition, (Gian Luca D'Errico, U. Bologna); The Inquisition in the Reign of Philip and Mary 1554-1558 (John Edwards, U. Oxford); "Como un cuerpo sin brazos". Aplicación y alcance de la justicia inquisitorial en los territorios virreinales surperuanos durante el último cuarto del siglo XVI (Federico Tulio Sartori Moyano, U. Nacional de Cordoba); D. João de Melo e Castro, Primazia e pertinacia de um inquisidor (D. Norte Giebels); Inquisição e franciscanos em Cabo Verde no século XVII (M. Santos); Cooperação espontânea e requerida entre as justiças eclesiástica e inquisitorial na vigilância e erradicação da luxuria clerical no Atlântico português (1640-1750) (Jaime Ricardo Teixeira Gouveia, CHAM, U. Nova LisboaCHSC, U. Coimbra); O processo inquisitorial de D. frei Inácio de Santa Teresa em Goa (1725-1737), (Ana Rua Alves, U. Católica Lisboa). Também nessa sessão foi evidente como não só os membros da Ordo Praedicatorum eram 
os indefessos "cães da ortodoxia", mas um conjunto de forças e instituições como franciscanos, jesuítas, outros ministros civis e eclesiásticos que colaboraram com os tribunais do Santo Oficio.

As amplas cronologias e conjunturas específicas visadas nesse ST2, assim como a abordagem iconográfica - tratada pela investigadora do CHSC, P. Nestola - e os comportamentos luxuriosos heresiarcas do clero - propostos pelo investigador CHAM-CHSC, J. Gouveia - caracterizaram também outras reuniões de maneira mais pormenorizada, como na M5 Las últimas inquisiciones entre Europa y América. Conflictos, estrategias y debate historiográficos (coord. Andrea Cicerchia, U. Urbino); M3 Inquisición y la represión de los pecados/delitos de la carne, (coord. Luiz Mott, U. Federal de Bahia); e na ST3 Fuentes documentales y archivos inquisitoriales (Ignacio Panizo Santos, Archivo Histórico Nacional; Laura Lavado Suárez, U. Complutense de Madrid). Foi esse um dos simpósios mais comprido, articulado nos três dias por um total de 25 comunicações. Foram apresentadas novas fontes de muitos arquivos ibéricos, assim como os detalhados programas informáticos utilizados conforme abrangentes questionários (Nuevas ventanas para viejas fuentes: el proyecto Post Scriptum y su tratamiento de las fuentes inquisitoriales españolas $y$ portuguesas, Laura Martínez Martín, Guadalupe Adámez Castro, FLUL). Do extenso ST3, destacou-se a comunicação sobre um monumento/documento da Inquisição de Sicília, Palazzo Steri em Palermo, onde as prisões guardam ainda os grafíti realizados pelos presos pela fé (Graffiti e disegni murali nelle carceri inquisitoriali di Palermo, Giovanna Fiume, U. Palermo). Micro-universos se desvelam através dessas invulgares fontes realizadas com os mais variados materiais além da tinta; de maneira que excrementos, esperma, pigmentos de distinta natureza e criatividade deram voz a indivíduos, cujas histórias judiciárias se podem reconstruir através das fontes processuais guardadas no AHNM. Muitas vezes através do fio nominativo - as assinaturas deixadas por esses presos enquanto "disenhavam" - podemos penetrar no background confessional mas também no dia-a-dia, no quotidiano, no(s) tempo(s) do mundo obscuro ou sem luz das prisões, e simultaneamente populado por santos e santas como Santa Lúcia, São Sebastião, outros santos taumaturgos ou com outras características. Um panteão celeste representado nas paredes juntamente com bispos, cavaleiros, navios ou espaços geográficos.

São inúmeros os estímulos para os novos enfoques historiográficos e para o cruzamento de dados fornecidos pelos estudos dos especialistas e historiadores que se congregaram na Universidade de Cisneros e que não podemos referir nesta curta notícia. Contudo, eis que as breves comunicações das distintas mesas e simposia puderam encontrar ulteriores momentos de reflexão 
no decorrer dos lançamentos de estudos recém editados, apresentados entre desafiantes pequenos momentos de troca intergeneracional, ou cruzando os olhares nas propostas de leitura dos livros: Isabel Drumond Braga, Viver e morrer nos cárceres do Santo Ofício, A Esfera dos Livros, 2015, apresentado por Fernanda Olival (U. Évora); João Furtado Martins, Corrupção e incúria no Santo Ofício, ministros e oficiais sob suspeita e julgamento, Centro Estudos de História Religiosa, Lisboa, 2015; Jaime Gouveia, A quarta porta do Inferno. A vigilância e disciplinamento da luxúria clerical no espaço luso-americano (16401750), Chiado Editora, 2015, ambos apresentados por Isabel Drumond Braga (U. Lisboa); A Inquisição de Goa. Descrita por Charles Dellon (1687), Estudo, edição e notas por Charles Amiel e Anne Lima, Ed. Phoebus, São Paulo, 2014, lançado pelo mesmo tradutor em português Bruno Feitler (U. Federal de São Paulo); Yllan de Mattos, A Inquisição contestada: críticos e críticas ao Santo Ofício português (1605-1681), Mauad, Rio de Janeiro, 2014, apresentado por J. Ricardo Gouveia (U. Coimbra-U. Nova Lisboa); Gerardo Lara Cisneros, ¿Ignorancia invencible? Superstición e idolatría ante el Provisorado de Indios y Chinos del Arzobispado de México en el siglo XVIII, U. Nacional Autonoma de México, 2015, introduzido por Gabriel Torres Puga (El Colegio de México).

À luz desses itinerários historiográficos é evidente como as fronteiras inquisitoriais se tornam sempre mais ténues, até desvanecer a incomunicabilidade e a falta de conhecimentos sobre as Inquisições do Mediterrâneo, denunciadas em um famoso artigo de Annales Histoire Sciences Sociales de 2002. Inquisições que abrangem desde o Oceano Atlântico até o Pacifico, num périplo de localizações, territórios, culturas, confissões, etnias distintas, incidindo sobre outras temáticas especificas da História, de maneira que se tornam sempre mais história(s) cruzada(s), comparada(s), global(ais), interconectada(s). Também nesse III Simpósio se ultrapassaram os limites de historiografias nacionais, favorecendo a discussão intelectual e a colaboração internacional entre historiadores: um debate muitas vezes cimentado e estimulado por uma activa pedagogia da pergunta, que dirige e dirigirá a lupa analítica de antigos ou novos investigadores.

Paola Nestola 


\section{Congresso Internacional da Commission Internationale de}

Diplomatique, École Française de Rome, 10 a 11 de setembro de 2015

Decorreu em Roma, entre os dias 10 e 11 de setembro de 2015, o XIV Congresso Internacional da Commission Internationale de Diplomatique, dedicado ao tema "I documenti del commercio e dei mercanti tra medioevo e età moderna", tendo os respetivos trabalhos decorrido na Sapienza - Università di Roma e nas instalações da École Française de Rome, numa iniciativa coordenada cientificamente por Cristina Mantegna (Sapienza-Università di Roma) e Olivier Poncet (École nationale des chartes).

As sessões deste Congresso subdividiram-se pelos temas "L'Europa dei documenti commerciali I - Il medioevo mediterraneo (XII-XV secolo)", "L'Europa dei documenti commerciali II. Dalla Manica agli Urali (XII-XVII secolo)" e "I tempi moderni e l'Atlantico (XVI-XVII secc.). A conferência de abertura foi assegurada por Giovanna Nicolaj, que expôs as problemáticas gerais deste género documental, seguindo-se 20 comunicações de diferentes especialistas oriundos de países como Itália, Alemanha, França, Espanha, Estados Unidos da América, Bélgica, Suécia, República Checa, Hungria, Rússia e Portugal. Da parte portuguesa foram apresentadas duas comunicações, a de José Marques, Cristina Almeida e Cunha Alegre e Maria João Oliveira Silva, intitulada "Les contrats commerciaux des marchands de Porto et du Nord-ouest atlantique portugais au début de l'epoque moderne", e a de Maria Helena da Cruz Coelho e Saul António Gomes, com o título "Lettere e documenti di mercanti nel Portogallo del Cinquecento."

Os documentos relativos às práticas comerciais são comuns em todo o Ocidente, assumindo importância particular nos séculos medievais, como o demonstram os ricos arquivos dos países mediterrânicos, e também na Europa setentrional e de leste, onde a atividade comercial europeia floresceu de forma notável na plenitude dos tempos medievais e modernos. Neste contexto, a Península Ibérica, como o demonstraram as diversas comunicações aduzidas pelos especialistas originários de universidades de Espanha e Portugal, afirmou-se como espaço singular, atlântico e mediterrânico, produtor de documentação própria custodiada, outrora, em arquivos públicos e privados, com particular importância para os diplomas de produção notarial e também das chancelarias régias dos diversos reinos peninsulares. 


\section{O mundo lusófono em movimento: (r)evoluções e transforma- ções/"Umbrüche und Aufbrüche: Die portugiesischsprachige Welt in Bewegung". $11^{\circ}$ Congresso de Lusitanistas Alemães, Aachen, 16 a 19 de setembro de 2015}

A Universidade de Aachen acolheu, entre 16 e 19 de Setembro de 2015, o $11^{\circ}$ Congresso de Lusitanistas Alemães, subordinado à temática geral: $O$ mundo lusófono em movimento: (r)evoluções e transformações / "Umbrüche und Aufbrüche: Die portugiesischsprachige Welt in Bewegung". O evento atraiu largas centenas de especialistas de várias partes do mundo lusófono, que, de uma forma ou de outra, mantêm ligação com a cultura germânica.

Compreende-se a escolha do local para a realização deste magno encontro cultural e científico. Desde 1983 que a Lusitanística integra os estudos europeus da Faculdade de Filosofia da RWTH Aachen, fazendo parte, em particular, do programa científico do Departamento de Línguas, Literaturas e Culturas Ibero-Românicas. Por questões orçamentais, a sobrevivência desta área de estudos parece hoje ameaçada, pese embora a intensa cooperação mantida pela Faculdade de Filosofia da RWTH Aachen com outras universidades e professores europeus, africanos, sul-americanos e asiáticos. Entre muitos projetos empreendidos com assinalável êxito nesta área de estudos destaca-se a edição de uma primeira série de 16 volumes de fontes portuguesas, em impressão fac-símile, sobre a História do Sultanato de Omã. A investigação e publicação da referida obra resultou de uma parceria do Instituto de História da Construção de Aachen com o Sultanato de Omã e a Universidade Nova de Lisboa. Esta ação que se espera tenha continuidade, com a transcrição de outras fontes e a tradução das mesmas em inglês e árabe, acompanha a crescente projeção que a Lusitanística alcançou, desde os anos oitenta do século passado, nos conceituados cursos técnicos e económicos da RWTH Aachen.

Retomando o programa do $11^{\circ}$ Congresso de Lusitanistas Alemães, refira-se que, sob a presidência de Anne Begenat-Neuschäfer, as 16 secções previstas, confiadas aos respectivos coordenadores, contaram com a participação de 217 comunicantes e conferencistas. Distribuídas por diversos temas, estudos culturais, literatura, linguística e media, os trabalhos das secções foram particularmente produtivos. Dada a diversidade de enfoques e assuntos em debate, a circulação de participantes tendeu a privilegiar os resultados de investigação que cada grupo de trabalho tinha inscrito no pro- 
grama do Congresso, previamente publicado num extenso Reader de 254 páginas. Na seção em que mais intensamente participámos, coordenada por Tobias Brandenberger (Georg-August-Universität Göttingen) e Vanda Anastácio (Universidade de Lisboa), as comunicações apresentadas versaram sobre Transferência cultural e redes no feminino no mundo lusófono. Para além dos coordenadores, nela intervieram com comunicação Anne-Marie Quint (Université de la Sorbonne-Paris III), Dimitri Almeida (Georg-August-Universität Göttingen), Aenne Gottschalk (Georg-August-UniversitätGöttingen), Annete Paatz (Georg-August-Universität Göttingen), Elisabeth Batista (Universiade do Estado de Mato Grosso), Zulmira Santos (Universidade do Porto), Paula Almeida Mendes (Universidade do Porto), Anabela Couto Galhardo (Universidade Aberta), Sandra Boto (Universidade do Algarve) e eu pela Universidade de Coimbra.

O Congresso acolheu ainda, no seu primeiro dia de trabalhos, o encontro de jovens investigadores lusitanistas, cuja criação foi impulsionada por Teresa Pinheiro e Robert Stock no Congresso anterior, realizado em Hamburgo, em 2013. Como novidade desta edição e correspondendo à capacidade de realização do Instituto Camões, presidido por Ana Paula Laborinho, assinale-se a reunião e constituição de uma mesa redonda com a presença de embaixadores da Comunidade dos Países de Língua Portuguesa moderada por Helmut Siepmann.

O rico e bem organizado programa do Congresso incluiu dois espetáculos musicais, uma recepção solene no salão nobre Krönungssaal da cidade, uma visita guiada à majestosa Catredral de Aachen e a entrega do prémio de investigação Georg Rudolf Lind.

Por fim, assinale-se a ocorrência simultânea de duas interessantes exposições de alcance patrimonial: uma sobre o "Valor da Língua Portuguesa" e outra sobre "Os Vestígios Portugueses em Omã.. Em suma: nos três preenchidos dias de trabalho e confraternização vividos na cidade de Carlos Magno, centro unificador da velha Europa, experimentámos a satisfação intelectual e a alegria imensa de participar com a nossa língua e cultura num mundo global.

Ana Cristina Araújo 


\section{Você tem fome de quê, "Dos prazeres da mesa aos cuidados do corpo". III Colóquio DIAITA Luso-brasileiro de História e Cul- turas da Alimentação, Faculdade de Letras da Universidade de Coimbra, 19 a 21 de outubro de 2015}

Financiado por instituições portuguesas como a Fundação para a Ciência e a Tecnologia e a Fundação Calouste Gulbenkian, sob os auspícios da Faculdade de Letras da Universidade de Coimbra, da Faculdade de Ciências Sociais da Universidade Nova de Lisboa e do Palácio Nacional de Ajuda, realizou-se em Coimbra o III colóquio DIAITA Luso-brasileiro de História e Culturas da Alimentação, entre os dias 19 a 21 de Outubro. Organizado pelo projecto DIAITA, com investigadores das Unidades de Investigação Centro de Estudos Clássicos e Humanísticos ( $\mathrm{CECH})$, Centro de História da Sociedade e da Cultura (CHSC) e Instituto de Estudos de Literatura Tradicional (IELT), com a parceria da Câmara Municipal de Coimbra, este colóquio teve como tema principal "Dos prazeres da mesa aos cuidados do corpo".

No ano da Expo2015, a exposição universal consagrada à alimentação e à nutrição, o reflector português ilumina-se no momento em que está a acabar o evento que em Milão, de 1 de Maio a 31 de Outubro, tem como lema "Feeding the Planet, Energy for Life". Durante este ano e no semestre da Expo 2015, foram muitas as iniciativas que quiseram celebrar a comida nas suas distintas representações sociais, simbólicas, territoriais e culturais. Destacaram-se as mostras divulgativas e um mega-congresso internacional, organizado na primeira semana de Setembro, em Pádua pela AISU (Associação Italiana de História Urbana), com o tema "Food and the City".

Porém, na cidade do Mondego a clepsidra do tempo alimentar não está no fim do seu fluir. Pelo contrário, oferece uma nova linha de oportunidades com o terceiro encontro DIAITA, estabelecido pela Comissão organizadora, composta pelas professoras Maria Helena da Cruz Coelho (FLUC/CHSC-UC), Carmen Soares (FLUC/CECH-UC) e Inês de Ornellas e Castro (FCSH-UNL/IELT).

Se é verdade que as sociedades tradicionais associavam a preparação e o consumo de um alimento a uma data específica do calendário, prosseguiu-se, no início da estação outonal - do hemisfério setentrional - com cronologias, territórios e temáticas sócio-alimentares que têm alcançado um excelente nível de maturidade científica. Em resultado deste saudável princípio, a escolha de celebrar o colóquio associado ao projecto transnacional DIAITA 
"Património Alimentar da Lusofonia", não foi ao acaso; quase parece para coroar este momento com a partilha de experiências de investigação com um renovado brinde. Um chinchin que poderia soar desde a clássica exclamação horaciana Nunc est bibendum, até ao mais recente Comida, do famoso grupo musical brasileiro Titãs.

No país da Península Ibérica que sempre se propõe mais, a nível mundial, com produtos e territórios vitivinícolas de excelência, o vinho, na verdade, não foi o único alimento do convívio científico português; pelo contrário, retomando umas das letras do êxito musical paulista: "A gente não quer só comer/A gente quer comer e quer fazer amor/A gente não quer só comer/A gente quer prazer para aliviar a dor......

De facto, além das intervenções sobre essa componente alimentar básica para muitas culturas, transformado também em antiséptico ou em veículo para misturar fármacos, como mostraram Cinthia Elisabet Otto Rolla (As ligações do vinho com as referências poéticas em Miguel Torga, Eça de Queirós e Charles Baudelaire), ou Raquel Maria Fino Seiça da Universidade de Coimbra, Faculdade de Medicina ( $O$ vinho do Bem-estar da Mesa e do Corpo), os tópicos e as linhas programáticas a tratar foram mais amplas. Isso se depreende das palavras da Comissão organizadora: "Os testemunhos imateriais e materiais da história e cultura da alimentação tornam evidente, desde a pré-história aos nossos dias, como a mesa - entendida no sentido completo de produção, confecção e consumo de bens alimentares, bem como de comportamentos e rituais que lhe estão associados - não se limita à satisfação de necessidades elementares e biológicas de sobrevivência. Desde muito cedo o ser humano deixou impressas, na memória tangível e intangível do passado, as determinações que o gosto impôs às suas escolhas alimentares".

Assim, para conhecer os padrões alimentares aconselhados ou proibidos, consideraram-se fontes heterogéneas, tais como os textos medievais e modernos. Foi o caso das propostas de Andrew Dalby, baseadas nos manuscritos e iluminuras (Dioscorides Reborn. The reincarnations of a classical authors), ou de Inês de Ornellas e Castro com a sua $A$ mesa melancólica, a partir de um livro da primeira metade do século XVII que se debruçava sobre o animi angorem (angústia do espírito) e os seus alimentos curativos; e de Paola Nestola, FCT, CHSC, Universidade de Coimbra, "Et il fuoco fa che la pignata mandi sopra la schiuma"... Quando a luxuria está na cozinha? Textos hagiográficos franciscanos, pecados da carne e disciplinamento social, com as metáforas culinárias da lusofonia franciscana medieval que se cruzavam com os jogos simbólicos, linguisticos e pedagógicos das receitas em língua italiana propostas na primeira metade de Seiscentos por membros da mesma ordem, e elaboradas 
para alcançar uma espiritual Dieta Salutis. Além de manuscritos napolitanos ou de livros portugueses, também as obras de Galeno e de Hipócrates, de Svetonio, de Pedanius Dioscurides Anazarbeus, de Petronio ou de outros autores clássicos contribuíram para revelar costumes e hábitos alimentares, testemunhando - em estrofes gregas ou latinas - momentos de sociabilidade não só de imperadores mas também de outras categorias antigas. As comunicações de David Lew, Bar-Ilan University, (You are what you eat: Emperor's virtues and vices as represented by food in Svetonius' de Vita Caesarum), de Virginia Mastellari, Albert-Ludwigs -Universitat Freiburg, (Food and Parties: seduction, erotic and sexual appetite in greek comic fragments) e de Alexandra Santos, CECH, Universidade de Coimbra, Os pueri delicati na volúpia do banquete romano constituíram exemplos dessa multiplicidade de abordagens.

O programa do colóquio, de facto, foi composto por seis painéis temáticos (Alimentação na Antiguidade; Alimentação e Mobilidade; Alimentação e Religião; Alimentação e Cultura; Alimentação e Saúde) e por uma mesa redonda (Alimentação e Arqueologia Histórica), contando com um total de 45 comunicações, avaliadas por uma heterogénea comissão cientifica euro-brasileira da qual se destacam especialistas de longo curso como Ana Isabel Buescu, (Universidade Nova de Lisboa, Portugal), Anny Jackeline Torres Silveira (Universidade Federal de Minas Gerais, Brasil), Expiración García Sánchez (Escuela de Estudios Árabes, CSIC, Espanha), Henrique Soares Carneiro (Universidade de São Paulo, Brasil), Joaquim Pinheiro (Universidade da Madeira, Portugal), Jean-Pierre Williot (Universidade Francois Rabelais, Tours, França), John Wilkins (University of Exeter, Inglaterra), Leila Mezan Algranti (Unicamp, Brasil), Maria Cecília Amorim Pilla (Pontifícia Universidade do Paraná, Curitiba, Brasil), María José García Soler (Uni. do País Basco, Espanha), Maria José Azevedo Santos (Uni. Coimbra, Portugal), Massimo Montanari, (Uni. Bologna, Itália) Paula Barata Dias (Uni. Coimbra, Portugal), Rebecca Earle (Un. Warwick, Inglaterra), Tânia Andrade de Lima (Museu Nacional, Universidade Federal do Rio de Janeiro, Brasil).

Tudo isso complementado pelas conferências de abertura de Leila Mezan Algranti, UniCamp, A Botica colonial: apontamentos sobre saúde e alimentação na América portuguesa (sécc. XVI-XVIII), e de Cilene Ribeiro, Pontifícia Universidade Católica do Paraná, Memórias da alimentação e fatos da imigração de luso-brasileiros, residentes em Curitiba, centradas sobre épocas e tipologias documentais distintas da América portuguesa.

No fim do primeiro dia de trabalhos, assistiu-se - na espectacular Biblioteca Joanina - ao lançamento dos livros Odisseias de Sabores da Lusofonia, Coimbra e Curitiba, coordenado por Cilene Gomes Ribeiro \& Carmen 
Soares, Imprensa da Universidade e PUCPress, 2015; Sabores e Segredos. Receituários Conventuais Portugueses da Época Moderna, da autoria de Isabel Drumond Braga, editado pela Imprensa da Universidade de Coimbra em 2015; e A nossa mesa: receituário gastronómico da Figueira da Foz, com textos de Guida Cândido e publicação da Câmara Municipal, 2015.

No decorrer das ulteriores etapas do intenso programa do Colóquio, inaugurou-se a exposição BiblioAlimentaria que disponibilizou um conjunto de manuscritos e livros, provenientes do acervo documental e bibliográfico da Universidade de Coimbra, subordinado a três temas: Alimentação e Saúde; Alimentação e Farmacopeia; e finalmente Alimentação e Memória Gastronomica.

Os participantes no colóquio puderam ainda usufruir de concertos musicais, assim como da representação do "Suplício dos Doces", pela companhia de teatro Bonifrates, e ainda do workshop de Doçaria tradicional de Coimbra, organizado pela Pastelaria Briosa, uma das mais afamadas e premiadas da cidade de antigos conventos.

De acordo com o programa, a organização das sessões presididas por José Pedro Paiva, Francisco Oliveira, Norberto Santos, Rui Cascão, Francisco Contente Domingues, Maria Amélia Álvaro Campos, Ana Teresa Peixinho, Betânia Figueiredo, Cilene Ribeiro, Delfim Leão, Raquel Vilaça, Leila Algranti, José Augusto Bernardes, Raquel Fino Seiça, Isabel Drumond Braga, Irene Vaquinhas, evidenciou uma elaborada organização, que favoreceu a interligação entre a saúde física, o consumo alimentar e os estilos de vida, da Antiguidade até aos nossos dias. Por outro lado, a territorialização dos contextos de investigação, o cruzamento das fontes analisadas, a transversalidade da origem dos investigadores e dos seus centros de aferência constituiu também outra particularidade das comunicações do evento. Disso foram exemplo as intervenções de Bruno Laurioux (Université de Versailles Sain$\mathrm{t}$-Quentin-en-Yves/Paris-Saclay), Back to an old question with many answers from the 5th c. B.C. to 21 st c. A.D.; de Wanessa Asfora Nadler, Universidade de São Paulo, Apício como opus medicinale na Itália do século XV: estudo de caso a partir de três manuscritos florentinos; de Ilaria Berti, Universidade Pablo de Olavide, Britain outside Britain? Colonizers food and patterns of consumption in the 19th century Caribbean.

As comidas sólidas, cozinhadas de diferentes formas, e preparadas para momentos determinados da vida biológica ou do calendário do ano, propostas ainda em conjunturas de carência como a guerra - de acordo com a exposição de Maria Cecília Barreto Amorim Pilla, Pontifícia Universidade Católica do Paraná, Nas Páginas do Jornal das Moças: princípios de segurança 
alimentar em tempos de guerra (1914-1918) - não se podem pensar, porém, sem a interligação com os alimentos líquidos. O leite por exemplo, de origem humana (fornecido pelas amas-de-leite) e animal, de vaca ou de cabra, era o nutrimento básico na alimentação dos expostos de instituições como as Misericórdias, e por isso considerado tema principal de tratados científicos como aquele analisado por Kevin Carreira Soares, Universidade de Coimbra, em $A$ alimentação dos expostos no século XIX: norma, necessidade e práticas. Por sua vez, o vinho, mas também outras bebidas alcoólicas como a aguardente faziam parte do sistema dietético dos enfermos como explicaram Anny Jackeline Torres e Betânia Gonçalves Figueiredo (Universidade Federal de Minas Gerais), em Dietas e terapêutica nos oitocentos: a Santa Casa de São João del Rei, Brasil.

Além dos espaços da Universidade que neste ano comemora o seu $725^{\circ}$ aniversário, o mosteiro de Santa Clara-a-Velha foi outro lugar emblemático da cidade que hospedou o colóquio, e a mesa redonda coordenada por Tania Andrade Lima, Museu Nacional-Universidade Federal do Rio do Janeiro. De facto, com base numa abordagem etno-antropológica foi apresentado o emocionante Sistema Alimentar da cidade do Rio de Janeiro nos séculos XVIII- XIX, com a participação também de uma jovem equipe de investigadoras brasileiras. Destacaram-se, nesta apresentação, os estudos arqueológicos de restos faunísticos, mas também de cerâmicas e louças destinadas ao processamento, ao armazenamento, ao preparo, ao consumo e ao descarte de alimentos. As refeições desses territórios baseadas na carne - como a cabeça de boi - e visíveis através de interessantes fotografias do National Geographic documentaram as pesquisas efectuadas no Novo Mundo. Atrevemo-nos a dizer que estes testemunhos visuais lembravam outras obras clássicas europeias, como Il Macellaio (1974) de Renato Guttuso ou ainda O Boi Esquartejado (1655) de Rembrandt. Pinturas revolucionárias nas respectivas épocas de produção, as quais quase conseguiam incorporar e trasmitir o odor do sangue das carcaças dos animais figurados; analogamente, as cabeças de boi preparadas e consumidas pelos escravos brasileiros eram partes do animal que hoje em dia são apreciadas refeições, consideradas muito saborosas nas suas distintas partes como olhos, bochechas, focinhos, línguas, etc., conforme mostraram as "impressionantes" fotografias.

A maioria das pormenorizadas comunicações - como a de Cristina Neiva Correia, Palácio Nacional de Ajuda, A mesa Real no Palácio de Ajuda. Um projecto de múltiplas abordagens - deram conta das escolhas alimentares, da forma de aquisição e de armazenamento dos ingredientes e utensílios, da preparação e do consumo de comidas sólidas, liquidas ou semiliquidas, de 
alimentos podres, cozidos, assados, ensopados, ou fritos, doces e salgados. Por sua vez, outras intervenções basearam-se na metodologia quantitativa, agrupando para isso dados numéricos e estatísticos: foi o caso de Bruno Lopes, CIDEHUS-Universidade de Évora, em "Alimentar" o auto-de-fé: notas para o estudo dos gastos em cerimoniais; e de Isabel Drumond Braga, Universidade de Lisboa, com Anunciar alimentos e seduzir consumidores. A publicidade na Revista Ilustração (1926-1939). Poderíamos dizer uma matemática do consumo alimentar que complementava a descodificação institucional e publicitária, como no caso da principal cerimónia da Inquisição e dos homens do Tribunal da fé; ou como ilustravam os cartazes publicitários dos produtos da Nestlé, a empresa Anglo-Suiça que comercializava em Lisboa leite condençado e farinha apropriando-se das fotografias dos missionários que utilizavam o produto com as crianças africanas.

Uma abordagem mais simbólico-espiritual foi, por sua vez, aquela evidenciada nas propostas das estudiosas conimbricenses: Paula Barata Dias, Quando o doce é corpo. Antropomorfismo e Antroponímia na doçarias tradicional portuguesa; e Maria José Azevedo Santos, As "grades do doce" nos conventos da Ordem de Santa Clara, ambas centradas na experiência dos produtos e dos sabores com elevada concentração de açúcar e ovos como "suspiros", "barrigas" e "gargantas de freiras", "pingos de tocha", doces que reflectiam o quotidiano vivido por mulheres além das grades conventuais.

Não nos podemos esquecer nesta breve notícia de outras ligações do evento com o território português e com a cidade que nos recebeu. Na verdade, para além da doçaria conventual e regional conimbricense, devemos assinalar a participação de alunos e professores da Escola de Hotelaria e Turismo de Coimbra. De facto, foi nesse sossegado espaço que foi servida a Cena romana de encerramento, entre perfumadas refeições à base de castanhas, tâmaras, romãs, e aquecida com as declamações dos hinos de Safo, Alceo, Catulo, selecionadas pelo grupo teatral Thíasos, de cujos elementos lembramos Maria Amélia Álvaro Campos que fez parte também da comissão executiva do Colóquio, juntamente a João Pedro Gomes.

Tratou-se, verdadeiramente, de uma cornucópia de momentos de alegria e de sociabilidade, de intensas descobertas científicas úteis para a saúde do corpo e do espírito. Do mesmo modo, proporcionou um grande intercâmbio de conhecimentos sobre os patrimónios alimentares e os saberes e sabores luso-brasileiros, muitas vezes herdados da antiga dieta e cultura identitária do Mediterrâneo. Uma frutífera oportunidade de investigação científica que a anunciada publicação transformará, assim o desejamos, numa tangível referência para o futuro. 
Se na primeira metade do século passado, na sua Apologia da História, Marc Bloch usava a metáfora da fome da lenda do ogre, admoestando os aprendizes do ministerium da História, dizendo-lhes que a sua presa estaria onde cheirasse a carne humana; hoje, finalizando a experiência do III Colóquio DIAITA luso-brasileiro, podemos corroborar a sua desafiante advertência com as aliciantes perguntas musicais dos Titãs: "Você tem sede de quê? Você tem fome de quê?....”

PAOLA NeSTOLA

Universidade de Coimbra / CHSC nestolap@gmail.com 


\section{Teses de Doutoramento e/ou $3^{\circ}$ Ciclo e Dissertações /Relató- rios de Mestrado e/ou $2^{\circ}$ Ciclo orientadas ou co-orientadas por investigadores integrados do CHSC em 2014-2015}

Esta rúbrica tem por objectivo disponibilizar informação relativa às Teses de Doutoramento e/ou de $3^{\circ}$ Ciclo e Dissertações/Relatórios de Mestrado e/ou de $2^{\circ}$ Ciclo orientadas ou co-orientadas por investigadores do Centro de História da Sociedade e da Cultura, apresentadas e aprovadas no período compreendido entre 1 de Setembro de 2014 e 31 de Julho de 2015.

As referências vão ordenadas, dentro de cada tipo de prova, pela data da sua realização.

\section{Doutoramento ( $3^{\circ}$ Ciclo)}

Doutoramento ( $3^{\circ}$ Ciclo) - Letras, Área de História

Autor: Duarte Manuel Roque de Freitas

Título: Memorial de um complexo arquitectónico enquanto espaço museológico: Museu Machado de Castro (1911-1965)*

Especialidade: Museologia e Património Cultural

Data das provas: 20 de Maio de 2015

Instituição: Faculdade de Letras da Universidade de Coimbra

Orientador: Irene Vaquinhas

Co-orientador: Regina Anacleto

* Esta tese foi galardoada com o prémio Victor de Sá de História Contemporânea para o ano de 2015.

Doutoramento (3 Ciclo) - Letras, Área de História

Autor: João Orlindo Simão Ventura Marques

Título: Pelos meandros do xisto: o património rural na freguesia de Vide

Especialidade: Museologia e Património Cultural

Data das provas: 22 de Junho de 2015

Instituição: Faculdade de Letras da Universidade de Coimbra

Orientador: Irene Vaquinhas

Co-orientador: Margarida Sobral Neto 


\section{Mestrado (e/ou de $2^{\circ}$ Ciclo)}

Mestrado /20 Ciclo - História

Autor: José Ricardo Gonçalves dos Santos

Título: Estudo para a criação de um Museu da Inquisição em Portugal

Especialidade: Especialização em Museologia

Data das provas: 8 de Setembro de 2014

Instituição: Faculdade de Letras da Universidade de Coimbra

Orientador: Irene Vaquinhas

Co-orientador: José Pedro de Matos Paiva

Mestrado /20 Ciclo - Alimentação. Fontes. Cultura e Sociedade

Autor: Luísa Fernanda Guerreiro Martins

Título: A alimentação em Loulé medieval (1384-1488)

Data das provas: 23 de Setembro de 2014

Instituição: Faculdade de Letras da Universidade de Coimbra

Orientador: Maria Helena da Cruz Coelho

Mestrado /20 Ciclo em Política Cultural Autárquica

Autor: Eufémia Maria de Oliveira Azevedo

Título: O perfil social da vereação viseense, 1770-1820

Data das provas: 23 de Setembro de 2014

Instituição: Faculdade de Letras da Universidade de Coimbra

Orientador: Maria Margarida Sobral da Silva Neto

Co-orientador: Ana Isabel Sacramento Sampaio Ribeiro

Mestrado /20 Ciclo - História

Autor: Ana Sofia Pimenta de Andrade

Título: Introdução às funções de um(a) registrar na Fundação de Serralves - Museu de Arte Contemporânea

Especialidade: Especialização em Museologia

Data das provas: 6 de Outubro de 2014

Instituição: Faculdade de Letras da Universidade de Coimbra

Orientador: Pedro Casaleiro

Co-orientador: Irene Vaquinhas

Mestrado /20 Ciclo - Estudos Europeus

Autor: Manuel dos Santos Simões

Título: A Grande Guerra de 1914-1918 e a invenção de uma tradição cívica. O culto do Soldado Desconhecido 
Data das provas: 9 de Outubro de 2014

Instituição: Faculdade de Letras da Universidade de Coimbra

Orientador: Isabel Maria Guerreiro Nobre Vargues

Co-orientador: Rui de Ascensão Ferreira Cascão

Mestrado $/ 2^{\circ}$ Ciclo - História

Autor: Ana Vanessa Duarte Lopes

Título: As primeiras Galas Internacionais dos Pequenos Cantores da Figueira da Foz (1979-1981): breve estudo histórico

Especialidade: História Contemporânea

Data das provas: 13 de Outubro de 2014

Instituição: Faculdade de Letras da Universidade de Coimbra

Orientador: Irene Vaquinhas

Mestrado / $2^{\circ}$ Ciclo - História

Autor: Ana Margarida Dias da Silva

Título: O Hospital e Asilo da Venerável Ordem Terceira da Penitência de São Francisco de Coimbra (1851-1926)

Especialidade: História Contemporânea

Data das provas: 13 de Outubro de 2014

Instituição: Faculdade de Letras da Universidade de Coimbra

Orientador: Maria Antónia Lopes

Mestrado / $2^{\circ}$ Ciclo - História

Autor: Soraia Cristina da Silva Pimentel

Título: Emigrar em tempos de guerra. A emigração no distrito de Coimbra em 19141918

Especialidade: História Contemporânea

Data das provas: 15 de Outubro de 2014

Instituição: Faculdade de Letras da Universidade de Coimbra

Orientador: Maria Antónia Lopes

Mestrado $/ 2^{\circ}$ Ciclo - Política Cultural Autárquica

Autor: Carlos Gustavo Santos Barreira

Título: A Procissão da Rainha Santa Isabel no Século XX: contextos e influências da Câmara Municipal de Coimbra nas Festas da Rainha Santa

Data das provas: 16 de Outubro de 2014

Instituição: Faculdade de Letras da Universidade de Coimbra

Orientador: Saul António Gomes 
Mestrado /2० Ciclo - História

Autor: Diogo José Teixeira Dias

Título: As Cortes de Coimbra e Évora de 1472-73. Subsídios para o estudo da política parlamentar portuguesa

Especialidade: Idade Média

Data das provas: 18 de Outubro de 2014

Instituição: Faculdade de Letras da Universidade de Coimbra

Orientador: Saul António Gomes

Mestrado /2० Ciclo - História

Autor: Diogo Silva Cancela

Título: Solidariedade internacional - A Revolução Argelina e os Movimentos Antifascistas

Especialidade: História Contemporânea

Data das provas: 22 de Outubro de 2014

Instituição: Faculdade de Letras da Universidade de Coimbra

Orientador: Rui de Ascensão Ferreira Cascão

Co-orientador: Ana Cristina Cardoso dos Santos Bartolomeu de Araújo

Mestrado /2० Ciclo - História

Autor: Ricardo Filipe São Bento

Título: Em busca de um lar para os Judeus - A hipótese de Angola

Especialidade: História Contemporânea

Data das provas: 22 de Outubro de 2014

Instituição: Faculdade de Letras da Universidade de Coimbra

Orientador: Rui de Ascensão Ferreira Cascão

\section{Mestrado $/ 2^{\circ}$ Ciclo em História}

Autor: António Jorge Santo Pinto

Título: A Gulf Oil Corporation na guerra colonial: estratégia para a permanência em Angola

Especialidade: História Contemporânea

Data das provas: 27 de Outubro de 2014

Instituição: Faculdade de Letras da Universidade de Coimbra

Orientador: Rui de Ascensão Ferreira Cascão

Mestrado /2० Ciclo - História

Autor: António Ferreira Cabete

Título: O Mosteiro de Santa Maria de Seiça. Das origens aos alvores da modernidade Especialidade: Idade Média 
Data das provas: 29 de Outubro de 2014

Instituição: Faculdade de Letras da Universidade de Coimbra

Orientador: Maria Alegria Fernandes Marques

Mestrado /20 Ciclo - História

Autor: Maria José Andrade Pinheiro Lázaro da Silva Correia

Título: Imagens do clero na obra de Gil Vicente

Especialidade: Idade Média

Data das provas: 29 de Outubro de 2014

Instituição: Faculdade de Letras da Universidade de Coimbra

Orientador: Maria Alegria Fernandes Marques

Co-orientador: José Augusto Cardoso Bernardes

Mestrado /2o Ciclo - Ensino de História e de Geografia no $3^{\circ}$ Ciclo do Ensino Básico e no Ensino Secundário

Autor: Ana Rita Figueiredo Craveiro

Título: As Aulas de Campo no processo de ensino/aprendizagem nas disciplinas de História e Geografia. Uma aula de campo no modelado cársico de Penela e na Villa Romana do Rabaçal

Data das provas: 3 de Fevereiro de 2015

Instituição: Faculdade de Letras da Universidade de Coimbra

Orientador: Adélia de Jesus Nobre Nunes

Co-orientador: Fernando Taveira da Fonseca

\section{Mestrado /20 Ciclo em História}

Autor: Diogo Filipe Matias Marques

Título: O domínio senhorial em Cantanhede nos finais do Antigo Regime

Especialidade: História Moderna

Data das provas: 5 de Fevereiro de 2015

Instituição: Faculdade de Letras da Universidade de Coimbra

Orientador: Maria Margarida Sobral da Silva Neto

\section{Mestrado /20 Ciclo - História}

Autor: Kamilla Dantas Matias

Título: A loucura na Idade Média. Ensaio sobre algumas representações

Especialidade: Idade Média

Data das provas: 11 de Fevereiro de 2015

Instituição: Faculdade de Letras da Universidade de Coimbra

Orientador: Maria Alegria Fernandes Marques 
Mestrado $/ 2^{\circ}$ Ciclo - Turismo de Interior-Educação para a Sustentabilidade Autor: Rui Pedro Fonseca da Rua

Título: Proposta de Dinamização Turística do Património de Abiúl

Data das provas: 12 de Fevereiro de 2015

Instituição: Escola Superior de Educação de Coimbra

Orientador: Maria do Rosário Castiço de Campos

Mestrado $/ 2^{\circ}$ Ciclo - Turismo de Interior-Educação para a Sustentabilidade Autor: Vasco André Gonçalves Coelho

Título: Marca «Água | Pão|Vinho | Leitão: 4 Maravilhas da Mesa da Mealhada» Data das provas: 8 de Julho de 2015

Instituição: Escola Superior de Educação de Coimbra

Orientador: Maria do Rosário Castiço de Campos

Mestrado $/ 2^{\circ}$ Ciclo - Mestrado Interuniversitário de História Militar

Autor: Paulo da Nazaré Marques dos Santos

Título: Cipião «o Africano» e a reinvenção do exército romano

Data das provas: 22 de julho de 2015

Instituição: Faculdade de Letras da Universidade de Coimbra

Orientador: João Gouveia Monteiro

Mestrado /20 Ciclo - Educação Especial

Autor: Luís Manuel Frias Rato Martins

Título: O Ensino da História, através da Banda Desenhada, a um Aluno do $8^{\circ}$ Ano de Escolaridade com Perturbações de Hiperatividade e Défice de Atenção: Estudo de Caso

Data das provas: 23 de Julho de 2015

Instituição: Escola Superior de Educação de Coimbra

Orientador: Maria do Rosário Castiço de Campos

Mestrado $/ 2^{\circ}$ Ciclo - Ensino de História e de Geografia no $3^{\circ}$ Ciclo do Ensino Básico e no Ensino Secundário

Autor: Guilherme Abrantes Matos

Título: Um olhar histórico-geográfico sobre a Cova da Beira

Data das provas: 28 de Julho de 2015

Instituição: Faculdade de Letras da Universidade de Coimbra

Orientador: Fernando Taveira da Fonseca

Co-orientador: Adélia de Jesus Nobre Nunes

Instituição: Faculdade de Letras da Universidade de Coimbra 


\section{Artigos}

Este bastón es mi padre / y madre mía esta espada: el poder de las obras y el poder de la sangre en El hijo de las batallas de Jacinto Cordeiro

MARIELA INSÚA

La erudita bufonería de La pícara Justina. Algunas notas

IGNACIO ARELLANO

D. Sebastião e Alcácer Quibir em duas comédias espanholas do Siglo de Oro: La Tragedia del Rey Don Sebastián y del Príncipe de Marruecos, de Lope de Vega, y Comedia Famosa del Rey Don Sebastián, de Luis Vélez de Guevara

ANTÓNIO APOLINÁRIO LOURENÇO

El discurso judiciario sobre Don Sebastián y el cometa de 1577

Jesús M. USUNÁRIZ

Aristóteles en el Banquillo: el prólogo al Libro del Nuevo Cometa de Jerónimo Muñoz FELIX K.E. SCHMELZER

Diplomacia e sociabilidade intelectual na viagem a Itália de D. Francisco Manuel de Melo Paulo Silva Pereira

En torno a una traducción inglesa del Buscón. "The pleasant story of Paul of Segovia", 1683 J. ENRIQUe DUARTE

"¡Qué amables tus moradas..." (Salmo 84 [Vg 83]), de fray Pedro Malón de Echaide, y el modelo de fray Luis de León para la paráfrasis de los salmos bíblicos

Carlos Mata Induráin

Da Hermenêutica da Controvérsia Luterano-Católica ao Diálogo Contemporâneo. O 5.ำ Centenário das 95 Teses de Lutero

Manuel Augusto Rodrigues

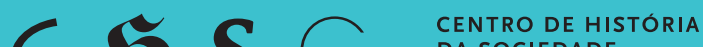 \\ $\checkmark$ E DA CULTURA}

FCT Fundação para a Ciência e a Tecnologia

MINISTIŔRIO Da FDUCAÇÁo E CIẼNCTA 